\title{
DINÂMICA ESPACIAL DO CANCRO CÍTRICO, INTERAÇÃO COM A LARVA MINADORA DOS CITROS (Phyllocnistis citrella) E DIVERSIDADE GENÉTICA DO SEU AGENTE CAUSAL (Xanthomonas axonopodis PV. citri)
}

\author{
JOSÉ BELASQUE JÚNIOR \\ Engenheiro Agrônomo
}

Orientadora: Profa. Dra. LILIAN AMORIM

\begin{abstract}
Tese apresentada à Escola Superior de Agricultura
"Luiz de Queiroz", Universidade de São Paulo, para obtenção do título de Doutor em Agronomia, Área de Concentração: Fitopatologia
\end{abstract}

P I R A C I C A B A

Estado de São Paulo - Brasil

Fevereiro - 2005 
Dados Internacionais de Catalogação na Publicação (CIP) DIVISÃO DE BIBLIOTECA E DOCUMENTAÇĀO - ESALQJUSP

\footnotetext{
Belasque Junior, José

Dinâmica espacial do cancro cítrico, interação com a larva minadora dos citros (Phyllocnistis citrella) e diversidade genética do seu agente causal (Xanthomonas axonopodis pv. citrı) / José Belasque Junior. - - Piracicaba, 2005.

171 p. : il.

Tese (Doutorado) - - Escola Superior de Agricultura Luiz de Queiroz, 2005. Bibliografia.

1. Bactéria aeróbica gram-negativa 2. Cancro cítrico 3. Epidemiologia 4. Larvaminadora-dos-citros 5. RFLP I. Título
} 


\section{Dedico}

Aos meus pais José e Edméa,

pelo amor, apoio e confiança sempre depositados. 


\section{AGRADECIMENTOS}

À Profa. Dra. Lilian Amorim, pela orientação, ensinamentos, sugestões e dedicação durante o curso de doutoramento e confecção do presente trabalho.

Aos pesquisadores Dr. Marcel Bellato Spósito, Dr. Pedro Takao Yamamoto, Dr. Waldir Cintra de Jesus Júnior e Dr. Renato Beozzo Bassanezi, pela valiosa contribuição, pelo apoio constante e amizade.

Ao Fundo de Defesa da Citricultura (Fundecitrus), em nome de Antônio Juliano Ayres, pela oportunidade e estrutura oferecidas na realização do doutorado, sem as quais o presente trabalho não teria sido realizado.

Aos professores Dr. Armando Bergamin Filho e Dr. José Roberto Postali Parra e aos pesquisadores Dr. Júlio Rodrigues Neto e Dr. John S. Hartung, pelos inúmeros ensinamentos e sugestões sempre valiosas.

De façon spécial à les cherchers Dr. Olivier Pruvost, Dr. Lionel Gagnevin et Dr. Christian Vernière, pour les précieux enseignements, l'amitié et l'opportunité de travail ensemble.

Aos colegas Ana Lia Gomes Cameiro Parra, Luciane Meire Ribeiro, Rock Seille Carlos Christiano e Marcone C. M. Chagas pelos inúmeros dias de trabalho em conjunto e a valiosa presença.

À Caroline Savelon, Nathalie Ah-You, Laurence Humeau, Emmanuel Jouen, Yan Piccard et Frederic Chiroleu pour l'amitié, les enseignements et la nombreuse aide.

À Escola Superior de Agricultura "Luiz de Queiroz" (ESALQ), o Departamento de Entomologia, Zoologia Agrícola e Fitopatologia, e o Pôle des Protection des Plantes do Centre de Coopération Internationale en Recherche Agronomique pour le 
Développement (CIRAD) pela oportunidade e estruturas disponíveis para a realização dos trabalhos de pesquisa.

À Fundação de Amparo à Pesquisa do Estado de São Paulo (FAPESP) e. ao Conselho Nacional de Desenvolvimento Científico e Tecnológico (CNPq) pelo apoio financeiro na realização de parte do presente trabalho e concessão de bolsa de estudo. 


\section{SUMÁRIO}

Página

RESUMO ....................................................................................

SUMMARY ..................................................................................... xii

1 INTRODUÇÃO .............................................................................. 1

2 REVISÃO DE LITERATURA ........................................................... 4

2.1 Importância econômica e localização geográfica do cancro cítrico ..... 4

2.2 Agente causal - Xanthomonas axonopodis pv. citri ........................... 5

2.3 Sintomatologia e etiologia ............................................................... 5

2.4 Interação do cancro cítrico com a larva minadora dos citros (Phyllocnistis citrella, Stainton, 1856) ............................................. 6

2.5 Epidemiologia e controle ............................................................. 8

2.6 Diversidade genética ...................................................................... 10

3 ESCALAS DIAGRAMÁTICAS PARA AVALIAÇÃO DA SEVERIDADEDO CANCRO CÍTRICO ......................................... 14

Resumo ............................................................................................. 14

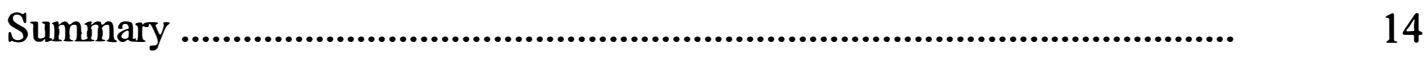

3.1 Introdução ..................................................................................... 15

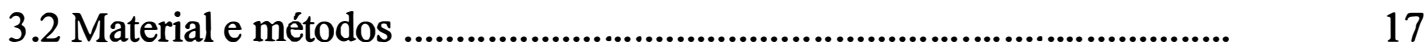

3.3 Resultados e discussão .................................................................... 18

4 AUSÊNCIA DA PROPAGAÇÃO DO CANCRO CÍTRICO (Xanthomonas axonopodis PV. citri) POR ADULTOS DA LARVA MINADORA DOS CITROS (Phyllocnistis citrella) .......................... 30

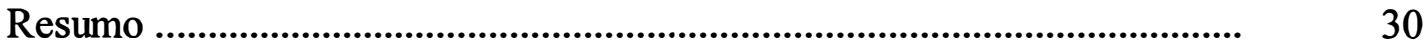

Summary .............................................................................. 30 


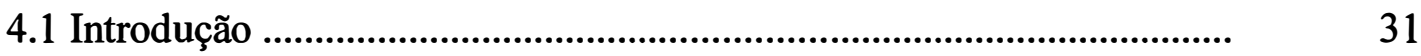

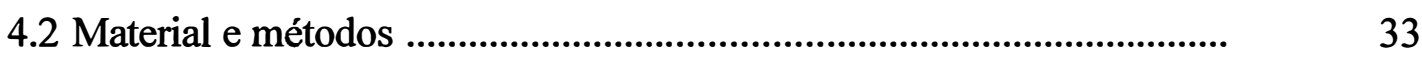

4.2.1 Propagação do cancro cítrico por adultos da larva minadora desenvolvidos em plantas doentes ....................................................

4.2.2 Propagação do cancro cítrico por adultos da larva minadora com acesso a plantas doentes e sadias

4.2.3 Transporte e deposição de Xanthomonas axonopodis pv. citri por adultos da larva minadora ................................................................. 37

4.2.4 Avaliações ............................................................................

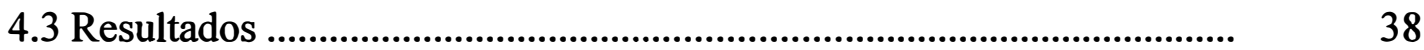

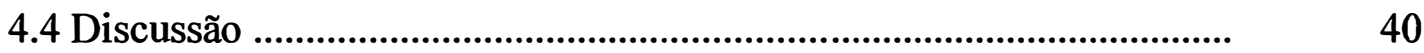

5 INJÚRIAS DA LARVA MINADORA DOS CITROS (Phyllocnistis citrella) INTENSIFICAM A INFECÇÃO POR CANCRO CÍTRICO (Xanthomonas axonopodis PV. citri) .................................................... 43

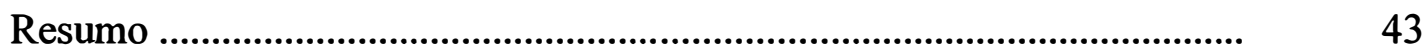

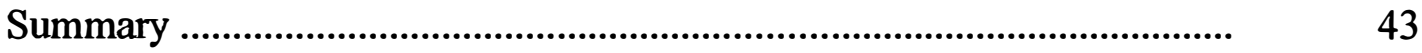

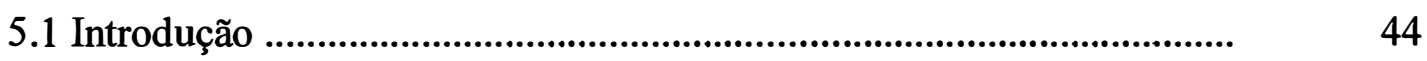

5.2 Material e métodos ..........................................................................

5.2.1 Efeito dos ínstares da larva minadora dos citros na infecção por Xanthomonas axonopodis pv. citri ................................................. 45

5.2.2 Comparação da idade de injúrias na infecção por Xanthomonas axonopodis pv. citri ......................................................................... 46

5.2.3 Avaliações e análise dos dados ..........................................................

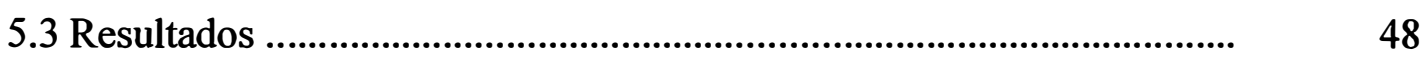

5.3.1 Efeito dos ínstares da larva minadora dos citros na infecção por Xanthomonas axonopodis pv. citri .................................................

5.3.2 Comparação da idade de injúrias na infecção por Xanthomonas axonopodis pv. citri ........................................................................ 49

5.4 Discussão ................................................................................... 
6 DINÂMICA ESPACIAL DO CANCRO CÍTRICO EM TALHÕES DE LARANJEIRA 'NATAL' SOB CONDIÇÕES NATURAIS DE INFECÇÃO

Resumo

Summary

6.1 Introdução

6.2 Material e métodos

6.2.1 Parcelas experimentais e coleta de dados

6.2.2 Análise de seqüências ordinárias

6.2.3 Dinâmica e estrutura de focos

6.2.4 Distâncias entre plantas doentes

6.2.5 Análise dos gradientes de doença

6.2.6 Determinação de áreas isópatas

6.3 Resultados

6.3.1 Incidência de plantas doentes

6.3.2 Análise de seqüências ordinárias

6.3.3 Dinâmica e estrutura de focos

6.3.4 Distâncias entre plantas doentes

6.3.5 Análises dos gradientes de doença

6.3.6 Determinação de áreas isópatas

6.4 Discussão

7 DIVERSIDADE GENÉTICA DE Xanthomonas axonopodis PV. citri NO ESTADO DE SÃO PAULO

Resumo

102

Summary

7.1 Introdução

7.2 Material e métodos

7.2.1 Isolados bacterianos

7.2.2 Southern blot (RFLP)

7.2.3 Análise dos dados de RFLP 
7.2.4 Fluorescent amplified fragment length polymorphism (FAFLP) ...... $\quad 114$

7.2.5 Análise dos dados de FAFLP ............................................................... 115

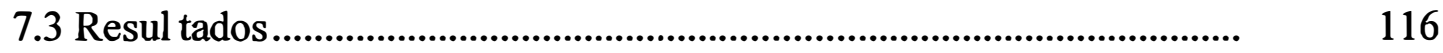

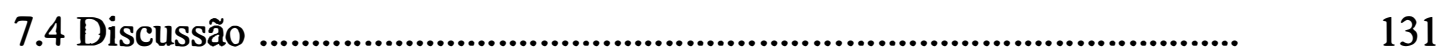

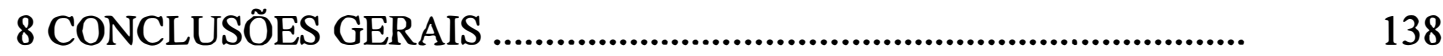

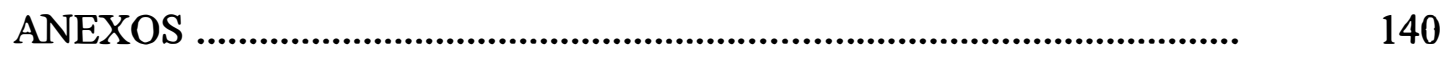

REFERÊNCIAS BIBLIOGRÁFICAS ...................................................... 155 


\section{DINÂMICA ESPACIAL DO CANCRO CÍTRICO, INTERAÇÃO COM A LARVA MINADORA DOS CITROS (Phyllocnistis citrella) E DIVERSIDADE GENÉTICA DO SEU AGENTE CAUSAL (Xanthomonas axonopodis PV. citri)}

Autor: JOSÉ BELASQUE JÚNIOR Orientadora: Profa. Dra. LILIAN AMORIM

\section{RESUMO}

O cancro cítrico é uma das principais doenças da cultura dos citros. Possui como provável centro de origem o Continente Asiático, no qual é endêmica, estando também presente nos dois maiores produtores mundiais de cítricos - Brasil e Estados Unidos. É caracterizada como uma doença quarentenária e programas de erradicação são empregados em áreas comerciais da cultura. No presente trabalho foram desenvolvidas escalas diagramáticas para auxiliar na avaliação da severidade do cancro cítrico em folhas, ferramenta útil na condução de estudos epidemiológicos e na avaliação da resistência varietal, entre outros exemplos. As avaliações realizadas com as escalas foram suficientemente acuradas, precisas e reprodutíveis e o treinamento dos avaliadores permitiu o aumento da precisão das estimativas. Outro aspecto importante deste 
patossistema é a interação existente com a larva minadora dos citros (Phyllocnistis citrella). Vários experimentos foram conduzidos, sob condições controladas, de modo a determinar se existe uma relação patógeno-vetor entre Xanthomonas axonopodis pv. citri e $P$. citrella, e também para explicar de que forma o inseto está envolvido nos aumentos da incidência e severidade do cancro cítrico. Verificou-se que a propagação do cancro cítrico, exclusivamente por adultos de $P$. citrella, não é um evento comum na natureza e, por essa razão, não possui importância epidemiológica. As injúrias provocadas pelas fases imaturas permitem maiores incidências da doença, com reflexos na área sob a curva de progresso da doença $(A U D P C)$, há uma redução no período de incubação em plantas infestadas com o inseto, os tecidos doentes apresentam maiores severidades e as injúrias demoram a cicatrizar, permitindo infecções por períodos mais longos. O estudo da dinâmica espacial do cancro cítrico em pomares sob condições naturais de infecção mostrou que as plantas doentes apresentaram-se sob padrão de agregação nas linhas de plantas e entre linhas, tendo sido mais pronunciado nas linhas. $\mathrm{O}$ estudo dos gradientes de doença revelou melhor ajuste do modelo Potência inversa à curva de incidência de doença em função da distância do foco inicial, e os coeficientes angulares obtidos decresceram com os aumentos da incidência. Foram observadas distâncias entre plantas doentes de até $177,16 \mathrm{~m}$, e as distâncias médias foram, na maioria dos casos, superiores a $30 \mathrm{~m}$. O estudo da diversidade genética de isolados de Xanthomonas axonopodis pv. citri (Xac), originários do Estado de São Paulo, usando-se genes IS's como sondas para Southern blot, permitiu a identificação de polimorfismo genético e a diferenciação de isolados de Xac. Os índices de diversidade genética obtidos variaram de 0,09 a 0,94 (Nei) e mostraram-se dependentes das populações e sondas estudadas. A técnica descrita é a de maior poder discriminante dentre as já testadas com Xac, sendo, potencialmente, a melhor técnica na definição da estrutura genética de populações desse patógeno e na identificação de origem de focos. Os resultados obtidos com FAFLP diferiram da genotipagem realizada com IS-RFLP e apenas seis haplótipos foram identificados. As sondas utilizadas permitiram uma relativa separação dos isolados, baseada nas populações estudadas e na origem geográfica destes, apesar da baixa robustez observada. 


\section{SPATIAL DYNAMIC OF CITRUS CANKER, INTERACTION WITH CITRUS LEAFMINER (Phyllocnistis citrella), AND GENETIC DIVERSITY OF ITS CAUSAL AGENT (Xanthomonas axonopodis PV. citri) ·}

Author: JOSÉ BELASQUE JÚNIOR Adviser: Profa. Dra. LILIAN AMORIM

\section{SUMMARY}

Citrus canker is one of the most important citrus diseases. Originated probably from Asia where it is endemic, this disease is currently present in the two most important citrus world producers - Brazil and U.S.A. Characterized as a quarentenary disease, eradication programs are developed in commercial areas. In the present work, diagrammatic scales were developed to standardize the assessments of citrus canker severity on leaves. The use of the diagrammatic scales provided more accuracy, precision and reproducibility during the evaluations. Another important aspect of this patossystem is the interaction of this disease with the citrus leafininer (Phyllocnistis citrella). After the introduction of leafminer in Brazil, in 1996, new and numerous focus of canker were found in association with the damages caused by this insect. Therefore, 
experiments were carried out to determine if there is a pathogen-vector relationship between Xanthomonas axonopodis pv. citri and $P$. citrella, and how the insect promoted an increase in the citrus canker incidence/severity. It was observed that the spread citrus canker by leafminer is not frequent in nature and therefore of limited epidemiological importance. However in insect damaged leaves, a higher disease incidence was observed, which increased the area under the disease progress curve $(A U D P C)$, the incubation period was shorter , and symptom severity was higher. Insect damaged leaves also remained prone to pathogen infection for longer periods of time. Spatial dynamic of citrus canker under natural infection conditions also was studied in this work. Higher aggregation of diseased plants occurred in within rows than in between rows. The power law was the model that better described the disease gradients. The increase of disease, associated with the host growth, resulted in steeper disease gradients and lower slopes (b). Distances between diseased plants were up to $177.16 \mathrm{~m}$, and the average distances were higher than 30 meters. The genetic study of strains of Xanthomonas axonopodis pv. citri, originated from São Paulo state, using genes IS's as probes to Southern blot, permitted the identification of genetic polymorphism and the differentiation of strains. The indexes of genetic diversity obtained were between 0.09 and 0.94 (Nei) and the results were dependent on the populations and probes. The technique has the best discrimination power, in comparison with other techniques, and, potentially, is the best technique to determine the genetic structure of the pathogen population and to identify the origin of disease focus. The results visualized by FAFLP were different from the genotipic characterization by IS-RFLP and only six haplotypes were identified. Besides the poor robustness observed, the used probes grouped the strains considering the pathogen populations and their geographic origin. 


\section{INTRODUÇÃO}

O cancro cítrico é uma das principais doenças da cultura dos citros (Stall \& Seymour, 1983; Stall \& Civerolo, 1991). Essa doença possui como provável centro de origem o Continente Asiático, no qual é endêmica e tem afetado muitas plantas da família Rutaceae (Koizumi, 1985). A partir da Ásia foi introduzido nas Américas do Norte e Sul, África do Sul e Oceania, regiões estas que abrigam dois dos mais importantes produtores de citros do mundo - Brasil e Estados Unidos (Stall \& Seymour, 1983; Civerolo, 1985; Schoulties et al., 1987). Nesses dois países a doença é considerada como quarentenária e ambos utilizam programas de erradicação para eliminar o patógeno de áreas comerciais da cultura (Barbosa et al., 2001; Gottwald et al., 2001; Stall \& Seymour, 1983).

A quantificação de doenças de plantas, ou patometria, é uma das mais importantes áreas da fitopatologia (James, 1974). Dois termos são comumente utilizados em fitopatometria: incidência e severidade, sendo o primeiro a porcentagem de plantas doentes, ou de partes de plantas doentes, e o segundo a proporção do volume ou da área do tecido com sintomas (Amorim, 1995; James, 1974). A quantificação de uma doença por incidência é mais fácil, precisa e simples, embora a severidade seja a variável mais apropriada na quantificação do cancro cítrico, uma vez que reflete mais acuradamente o progresso da doença que a incidência (Gottwald et al., 1989). Considerando a) a inexistência de chaves descritivas ou escalas diagramáticas que auxiliem na quantificação da severidade do cancro cítrico; e b) a necessidade da sua quantificação para estudos de epidemiologia, quantificação de danos e avaliação da resistência varietal, entre outros, foram elaboradas e validadas quatro escalas diagramáticas para a 
avaliação da severidade em folhas, resultados estes que compõem um capítulo do presente trabalho.

A introdução da larva minadora dos citros (Phyllocnistis citrella) no Brasil, em 1996, alterou a dinâmica da doença sob condições naturais de epidemia, com reflexos ainda não totalmente elucidados (Bergamin Filho et al., 2000). Associados às injúrias do inseto, novos focos da doença passaram a ser observados, o mesmo tendo ocorrido em outros países (Gimenes-Fernandes et al., 2000; Gottwald et al., 1997b). Uma das primeiras hipóteses que surgiram objetivando explicar a interação entre esses dois organismos refere-se à possibilidade do inseto ser um vetor da bactéria causadora do cancro cítrico, Xanthomonas axonopodis pv. citri (Xac). Vários experimentos sob condições controladas foram conduzidos de modo a elucidar não somente se existe uma relação patógeno-vetor entre Xac e $P$. citrella, mas também para explicar de que forma o inseto está envolvido nos aumentos da incidência e severidade do cancro cítrico. Esses estudos estão apresentados na forma de dois outros capítulos.

Em razão do cancro cítrico possuir o status de doença quarentenária, medidas de exclusão e erradicação são adotadas no Estado de São Paulo (Barbosa et al., 2001). Detectada a presença da doença, plantas sintomáticas e suspeitas de infecção são eliminadas. Incidências superiores a $0,5 \%$ de plantas doentes determinam a eliminação de todas as plantas do talhão. Para incidências iguais ou menores que $0,5 \%$, as plantas doentes, e as demais contidas num raio mínimo de trinta metros a partir das plantas doentes, são eliminadas. A adoção do raio de trinta metros na erradicação do cancro cítrico tem como base científica resultados obtidos na Argentina, os quais indicaram distâncias de disseminação da bactéria de até 38,1 metros durante chuvas associadas com ventos (Stall et al., 1980). Não há conhecimento de estudos prévios da epidemiologia do cancro cítrico em pomares, sob condições naturais de infecção, realizados no Estado de São Paulo, sendo as únicas exceções o estudo realizado por Bergamin Filho et al. (2000) e outro aqui apresentado no quarto capítulo.

A genotipagem de isolados de Xanthomonas patogênicos em Citrus tem sido feita objetivando, preferencialmente, a diferenciação dos patovares existentes. Relativo polimorfismo foi observado entre os grupos patogênicos de Xanthomonas, mas não 
dentro de cada patovar, com técnicas baseadas em PCR, análises por enzimas de restrição, pulsied field (PFGE) e restriction fragment length polymorphism (RFLP). A caracterização metabólica baseada na utilização do sistema Biolog não correlacionou-se com a origem geográfica, hospedeiro e ano de isolamento (Vernière et al., 1993). Mais recentemente, a genotipagem de uma coleção mundial de isolados de Xac por BOX e ERIC-PCR permitiu uma relativa caracterização de grupos genéticos e separou parcialmente isolados distantes geograficamente (Cubero \& Graham, 2002). Seqüências repetitivas de DNA (como insertion sequences-IS's), ou outra baseada em PCR, com a amplificação de fragmentos polimórficos (AFLP) são técnicas potencialmente úteis na genotipagem de populações de Xac e poderiam ser úteis na identificação da origem de focos de cancro cítrico. Como exemplo, a tipagem molecular por IS-RFLP de Mycobacterium tuberculosis, agente causal da tuberculose, é a técnica ideal em estudos que objetivam a identificação da origem de casos da doença (Otal et al., 1991). A caracterização molecular de uma coleção de isolados de Xac originários de São Paulo por RFLP e AFLP compõe o quinto capítulo do presente trabalho. 


\section{REVISÃO DE LITERATURA}

\subsection{Importância econômica e localização geográfica do cancro cítrico}

O cancro cítrico asiático, também denominado cancrose $\mathrm{A}$, é uma das mais graves doenças da cultura dos citros (Citrus sinensis, Osbeck) (Gottwald et al., 2001; Gottwald et al., 2002a; Stall \& Seymour, 1983). Seu agente causal, a bactéria Xanthomonas axonopodis pv. citri (Haase) Vauterin et al., encontra-se distribuído em dezenas de países localizados na Oceania, Ásia e América, infectando plantas da família Rutaceae (Civerolo, 1984). O provável centro de origem desta doença é a Ásia, onde é endêmica (Koizumi, 1985). Trata-se de uma doença quarentenária e o comércio mundial de cítricos é regulado por medidas de exclusão que visam impedir a entrada do patógeno em áreas livres da doença (Civerolo, 1985; Gottwald et al., 2001; Schoulties et al., 1987). Países com a presença de cancro cítrico estão sujeitos à imposição de restrições e barreiras fitossanitárias e medidas de exclusão e erradicação são adotadas nas principais regiões produtoras de cítricos do mundo - São Paulo e Flórida (Gimemes-Fernandes et al., 2000; Gottwald et al., 2001; Gottwald et al., 2002a; Gottwald et al., 2002b; Stall \& Civerolo, 1991).

A primeira ocorrência desta doença no Brasil foi em 1957, no município de Presidente Prudente, São Paulo (Bitancourt, 1957). Medidas de exclusão e erradicação foram adotadas neste mesmo ano e foi iniciada uma campanha de erradicação do cancro cítrico, que permanece ativa até os dias atuais (Gimenes-Fernandes et al., 2000). Apesar dos esforços iniciais, já em 1957 a doença foi encontrada nos Estados de Mato Grosso do Sul e Paraná (Amaral, 1957). Atualmente o cancro cítrico está presente nos Estados de São Paulo, Paraná, Santa Catarina, Rio Grande do Sul e Roraima e a campanha de 
erradicação da doença é válida em todo território nacional, com exceção do Estado do Paraná (Barbosa et al., 2001; Nascimento et al., 2003; Porto et al., 1981).

\subsection{Agente causal - Xanthomonas axonopodis pv. citri}

Xanthomonas axonopodis pv. citri (Xac), é uma bactéria gram negativa, aeróbia, bastonetiforme, com um flagelo polar, capaz de induzir sintomas em praticamente todas as espécies de Citrus além de outros gêneros da família Rutaceae (Gottwald et al., 1993; Graham et al., 1992). Em razão da existência de outros patovares de Xanthomonas axonopodis patogênicos em citros, aurantifolii e citrumelo, o cancro cítrico também é denominado "cancro cítrico Asiático" ou "cancrose A". O patovar aurantifolii possui como hospedeiro apenas limões verdadeiros e limas ácidas, sob condições naturais de infecção, tendo sido localizado somente na América do Sul. Em razão de diferenças quanto a patogenicidade e localização geográfica, o patovar aurantifolii possui dois tipos bacterianos, denominados " $\mathrm{B}$ " $\mathrm{e}$ " $\mathrm{C}$ ". O patovar citrumelo, também com patogenicidade limitada e ocorrência restrita a Flórida, possui a denominação de "tipo E" (Gabriel et al., 1988; Graham et al., 1990; Pruvost et al., 1992; Vernière et al., 1993). Há também dois outros tipos bacterianos formados por isolados do patovar citri com patogenicidade diferenciada e restrita a lima ácida 'galego' (Citrus aurantifolia), o primeiro encontrado no sudoeste asiático (tipo $\mathrm{A}^{*}$ ) (Vernière et al., 1998) e o segundo na Flórida (tipo A ${ }^{w}$ ) (Sun et al., 2000; Sun et al., 2004).

\subsection{Sintomatologia e etiologia}

Os sintomas constituem-se em lesões circulares, corticosas, salientes, de coloração amarronzada, aspecto eruptivo e rodeadas por anasarca, presentes em folhas, ramos e frutos (Bitancourt, 1957; Rossetti, 2001). Nas folhas e frutos é comum o aparecimento de um halo amarelo circundando a área necrosada. Em altas severidades pode ocorrer desfolha, queda de frutos e seca de ramos, sendo mais comuns em hospedeiros mais suscetíveis (Gottwald et al., 1988; Gottwald et al., 1989). Plantas 
cítricas afetadas constituem-se na principal fonte de inóculo da doença (Graham et al., 1987; Graham et al., 1989), já que a sobrevivência da bactéria é curta em qualquer outro substrato (Graham et al., 2000). Sob condições naturais de infecção a disseminação ocorre principalmente pela ação de respingos de chuvas e de chuvas associadas com ventos, e a disseminação a longas distâncias dá-se pelo transporte de material vegetal infectado (Civerolo, 1985; Danós et al., 1984; Gottwald et al., 1988; Gottwald et al., 1989). Atividades culturais como poda, colheita e pulverizações podem disseminar a bactéria entre plantas de um mesmo pomar (Civerolo, 1985; Danós et al., 1984; Gottwald et al., 1988). A infecção ocorre em tecidos jovens (Goto, 1990; Graham et al., 1992), durante períodos de crescimento do hospedeiro (Lee, 1921).

\subsection{Interação do cancro cítrico com a larva minadora dos citros (Phyllocnistis citrella, Stainton, 1856)}

Apesar de medidas de controle terem sido empregadas durante décadas, a partir de 1996, com a introdução no Brasil da larva minadora dos citros (Phyllocnistis citrella Stainton, 1856 - Lepdoptera: Gracillariidae: Phyllocnistinae) no sul do Estado de São Paulo (Prates et al., 1996), houve um importante aumento na incidência do cancro cítrico com conseqüências ainda não totalmente conhecidas para a citricultura paulista e brasileira (Bergamin Filho et al., 2000; Gimenes-Fernandes et al., 2000). O mesmo foi observado em outros países, como Estados Unidos (Gottwald et al., 1997b). A presença da larva minadora dos citros alterou o padrão espacial do cancro cítrico em São Paulo (Bergamin Filho et al., 2000). Antes da sua presença o cancro cítrico apresentava padrões de distribuição mais agregados. Após, foram observados padrões menos agregados e a presença mais comum de focos satélites, mais distantes dos focos iniciais da doença no talhão. Os ferimentos presentes nas plantas infestadas pela larva minadora facilitam a propagação da doença, e o inóculo transportado por respingos de chuvas e aerossóis tornou-se mais efetivo em infectar sítios localizados a maiores distâncias da fonte de inóculo inicial. Essa mudança no padrão espacial provocou a 
alteração da metodologia de erradicação do cancro cítrico em São Paulo em setembro de 1999 (Bergamin Filho et al., 2000; São Paulo, 1999).

A larva minadora dos citros é originária da Ásia e encontra-se distribuída nos cinco continentes (Achor et al., 1996; Heppner, 1993; Prates et. al., 1996). O adulto é uma pequena mariposa de aproximadamente 4,0 $\mathrm{mm}$ de envergadura, com asas anteriores de coloração branca a prata brilhantes, plumosas, apresentando um ponto preto na região apical, característico da espécie (Heppner, 1993; Garijo \& Garcia, 1994; Smith \& Hoy, 1995). A oviposição é realizada, na maioria dos casos, em folhas de brotações novas, mas em altas infestações pode ocorrer em ramos e frutos (Badawy, 1967; Clausen, 1931; Heppner, 1993; Prates et al., 1996). As lagartas ao eclodirem penetram no mesofilo foliar, provocando minas (galerias) típicas em forma de serpentina, causando a atrofia do tecido foliar, o qual assume uma coloração prateada, surgindo posteriormente manchas necróticas, culminando com a seca destas estruturas (Chagas \& Parra, 2000). Além do comprometimento à fotossíntese, as injúrias provocadas pela praga podem resultar na queda prematura das folhas e impedir o desenvolvimento das brotações, refletindo conseqüentemente no potencial produtivo do pomar (Badawy, 1967; Clausen, 1931; Heppner, 1993; Prates et. al., 1996).

As injúrias provocadas pela larva minadora dos citros constituem-se num fator de aumento na intensidade do cancro cítrico (Chagas et al., 2001; Cook, 1988; Gottwald et al., 1997b; Sinha et al., 1972; Sohi \& Sandhu, 1968; Venkateswarlu \& Ramapandu, 1992). Durante a alimentação as larvas rompem a cutícula e a epiderme e expõem o mesófilo foliar, tornando-o mais suscetível à infecção por Xac (Chagas et al., 2001; Gottwald et al., 1997b). Levantamentos realizados no Yemen revelaram a ocorrência de folhas infectadas com a doença associadas com danos desta praga. As pústulas de cancro cítrico desenvolveram-se, geralmente, somente em um dos lados das folhas, coincidindo com as minas provocadas pelo minador. $\mathrm{Na}$ maioria das vezes, as lesões coincidentes estavam na página inferior das folhas (Cook, 1988). Amostragens em laranja doce na Índia revelaram que $48,35 \%$ das folhas com danos de minador apresentaram também lesões de cancro cítrico. Por outro lado, apenas 3,18\% das folhas sem danos do minador apresentavam lesões de cancro cítrico (Venkateswarlu \& Ramapandu, 1992). Os autores 
também avaliaram o número de lesões de cancro/folha e sua relação com a ocorrência do inseto. O número médio de lesões de cancro foi de 3,39/folha, em folhas com danos do minador, e de 1,36 para folhas livres de danos da praga.

A peneração de bactérias fitopatogênicas em seus hospedeiros ocorre por aberturas naturais, geralmente estômatos, ou ferimentos (Crosse et al., 1972; Daft \& Leben, 1972). Chagas et al. (2001) verificaram que a taxa de infecção por cancro cítrico, em folhas lesionadas pelo minador, pode ser onze vezes maior em comparação com folhas intactas. Nesse estudo não foi avaliada a disseminação da bactéria por adultos de $P$. citrella. Apesar da relação existente entre o cancro cítrico e a praga já ser conhecida (Cook, 1988; Sohi \& Sandhu, 1968; Venkateswarlu \& Ramapandu, 1992), permanece obscuro de que forma exatamente o minador torna-se responsável por aumentos na incidência/severidade da doença (Chagas et al., 2001; Graham et al., 1996).

Considerando as hipóteses apresentadas na literatura e os dados científicos obtidos até então, as injúrias induzidas pela larva minadora em folhas cítricas constituem-se em novas e inúmeras aberturas para a entrada do patógeno no hospedeiro. Após estabelecido o processo de infecção, os sintomas coalescem e formam largas áreas necróticas, possivelmente também em razão dos ferimentos provocados pelo inseto. Largas áreas do hospedeiro ocupadas por lesões servem como fonte de inóculo mais efetiva, em razão do maior número de células bacterianas presentes (Chagas et al., 2001; Gottwald et al., 1988; Gottwald et al., 1989; Gottwald \& Graham, 1990).

\subsection{Epidemiologia e controle}

No Brasil o controle do cancro cítrico baseia-se principalmente em medidas de exclusão e erradicação e há medidas regulamentárias determinantes da erradicação de plantas e pomares quando afetados pela doença (Barbosa et al., 2001). Constatada a presença de cancro cítrico, a legislação federal determina a eliminação das plantas doentes e a adoção de um raio mínimo de trinta metros a partir das plantas doentes. As plantas contidas no raio, consideradas como suspeitas de infecção, devem ser completamente eliminadas, receberem uma poda drástica nos ramos, ou uma desfolha 
química (um dos três métodos). No Estado do Paraná a erradicação de plantas doentes, e das suspeitas de infecção, não é obrigatória e é permitida a adoção de práticas de manejo da doença, como a pulverização de cúpricos e implantação de cortinas quebra-vento (Leite Júnior \& Mohan, 1990).

No Estado de São Paulo a legislação, mais rigorosa que a válida nos demais estados, determina, após constatada a presença de cancro cítrico, a erradicação das plantas doentes e das demais suspeitas de infecção, mas o número de plantas a serem eliminadas depende da incidência de plantas doentes no talhão (Barbosa et al., 2001; São Paulo, 1999). Incidências superiores a $0,5 \%$ determinam a eliminação de todas as plantas do talhão. Em incidências iguais ou menores que $0,5 \%$, as plantas doentes, e as demais contidas num raio mínimo de trinta metros a partir das plantas doentes, são eliminadas. Não são aceitos como métodos de erradicação a poda drástica ou a desfolha das plantas suspeitas de estarem infectadas. Esta metodologia de erradicação passou a ser adotada em setembro de 1999. Anteriormente a esta data, a metodologia era a mesma válida atualmente para os demais estados brasileiros.

A disseminação do cancro cítrico ocorre predominantemente pela ação de respingos de chuvas e de chuvas associadas com ventos, sendo maior quando a velocidade do vento excede oito metros/segundo (Gottwald et al., 1988; Gottwald et al., 1989). Análises da distribuição espacial revelaram gradientes de doença mais abruptos no início da epidemia, em razão da maior concentração de plantas doentes a distâncias mais curtas do foco inicial (Gottwald et al., 1988). Coeficientes angulares da regressão linear entre a incidência transformada de doença (Gompit) e $o \log _{10}$ da distância do foco inicial, obtidos em condições experimentais, variaram de - 0,21 a - 4,13 (Danós et al., 1984). Em outro estudo foram observados gradientes menos abruptos (coeficientes angulares de - 1,86 a + 0,05), que variaram para diferentes hospedeiros e ao longo do tempo, como resultado da desfolha provocada pela doença (Gottwald et al., 1988). Os coeficientes angulares observados também variaram em razão da direção a partir do foco inicial, tendo sido maiores na direção predominante do vento. A análise de seqüências ordinárias revelou agregação de plantas doentes e os valores de $\mathrm{Z}$ variaram entre - 7,10 e - 3,01. Padrões mais agregados de doença ocorreram nas linhas, em comparação com a 
agregação entre linhas de plantas, em razão da maior proximidade destas nas linhas de plantio (Gottwald et al., 1988).

A adoção do raio de winta metros na erradicação do cancro cítrico tem como base científica resultados obtidos na Argentina, os quais indicaram distâncias de disseminação da bactéria de até 38,1 metros durante chuvas associadas com ventos (Stall et al., 1980). O Estado da Flórida, assim como o Brasil, passaram a adotar raios próximos a esta distância como método de erradicação do patógeno. Até maio de 2002 era válida na Flórida a adoção de um raio de 38 metros para determinação das plantas suspeitas de infecção a serem eliminadas. Um amplo estudo conduzido na região metropolitana de Miami, Flórida, revelou a ocorrência de infecções de cancro cítrico em plantas localizadas a distâncias que variaram de 12 a 3474 metros de plantas doentes, resultados estes utilizados na adoção de um novo raio de erradicação, de 579 metros (Gottwald et al., 2002a; Gottwald et al., 2002b).

Não há cónhecimento de estudos prévios da epidemiologia do cancro cítrico em pomares, sob condições naturais de infecção, realizados no Estado de São Paulo, sendo a única exceção o estudo realizado por Bergamin Filho et al. (2000), o qual resultou na mudança da metodologia de erradicação em São Paulo.

\subsection{Diversidade genética}

Métodos baseados em polimorfismo de fragmentos (RFLP-restriction fragment length polymorphism) foram utilizados para diferenciar estirpes de Xac associadas com diferentes epidemias do cancro cítrico e da mancha bacteriana dos citros (tipo E) na Austrália e na Flórida (Gillings et al., 1995; Graham \& Gottwald, 1991; Schubert et al., 1996). Nesses ou em estudos similares foram incluídas análises com enzimas de restrição (REA) de DNA total (Gillings et al., 1995), fragmentos de DNA clonados ao acaso de uma linhagem japonesa de Xac utilizada como sonda em análise de Southern (Hartung \& Civerolo, 1989; Hartung \& Civerolo, 1991; Gottwald et al., 1991) e eletroforese de campo pulsado (PFGE) (Egel et al., 1991; Gottwald et al., 1992a). 
Os perfís obtidos por REA (Gillings et al., 1995) são sempre de interpretação difícil. PFGE é normalmente, ou algumas vezes, menos discriminativa que seqüências repetitivas de DNA (como insertion sequences ou direct repeats) utilizadas como sondas para RFLP (Butcher et al., 1996; Morvan et al., 1997; Odaert et al., 1996; Olsen et al., 1997; Pestel-Caron \& Arbeit, 1998; Picardeau et al., 1997) e a tipagem por RFLP com sondas específicas apresenta uma técnica mais simples e rápida e com alto nível de reprodutibilidade entre laboratórios do que PFGE (Butcher et al., 1996). Além disso, em análises epidemiológicas, as quais exigem a tipagem de um grande número de estirpes, PFGE não pode ser aplicada.

O estudo de patógenos bacterianos geneticamente similares, objetivando a caracterização da estrutura genética da população, tem sido feito para patógenos humanos e vegetais por Southern blot (RFLP) empregando-se como sondas seqüências de inserção (insertion sequences-IS) ou genes avr (Hermans et al., 1990; Leach et al., 1995; Van Soolingen et al., 1991). Como exemplo, a tipagem molecular por IS-RFLP de Mycobacterium tuberculosis, agente causal da tuberculose, é a técnica ideal em estudos que objetivam a identificação da origem de casos da doença (Otal et al., 1991). A avaliação da diversidade genética de patógenos vegetais por Southern blot (RFLP) usando-se como sondas IS tem como melhores exemplos os realizados com $X$ oryzae pv. oryzae, X. pv. mangiferaeindicae e X. axonopodis pv. manihotis (Adhikari et al., 1999; Gagnevin et al., 1997; Nelson et al., 1994; Ochiai et al., 2000; Restrepo et al., 2000). O emprego desta técnica revelou uma diferenciação temporal e espacial de $X$. oryzae na Ásia, a migração do patógeno entre regiões e países, e a divisão da população do patógeno em grupos relacionados com as condições climáticas do local de origem, patogenicidade e raças (Adhikari et al., 1999; Leach et al., 1992; Nelson et al., 1994; Ochiai et al., 2000). Com a mesma técnica a diversidade genética de isolados de uma população mundial de $X$. mangiferaeindicae foi caracterizada, e os grupos genéticos formados correlacionaram-se com a região de origem e o hospedeiro. Maior diversidade foi encontrada entre isolados da Ásia, o centro de origem do patossistema, e isolados com patogenicidade diferenciada e originários de outros hospedeiros agruparam-se distintamente (Gagnevin et al., 1997). 
Seqüências repetitivas de DNA (que estão dispersas no genoma bacteriano e assim fornecem bandas múltiplas para análise dos dados), ou outra baseada em PCR, com a amplificação de fragmentos polimórficos (AFLP) são técnicas potencialmente úteis na genotipagem de populações de Xac. Basicamente, as características de valor para a tipagem epidemiológica são: (i) identificação e tipagem (resultados positivos com todos os isolados); (ii) reprodutibilidade; (iii) poder discriminatório; e (iv) facilidade de uso.

Elementos IS's são residentes naturais do genoma bacteriano. $\mathrm{O}$ alto potencial para se estabelecer perfís baseados em IS's em estudos epidemiológicos foi relatado pela primeira vez em 1987 por Sawyer et al., em pesquisas com Escherichia coli. Desde então IS's vêm sendo utilizados extensivamente e com sucesso em estudos epidemiológicos de vários gêneros e espécies bacterianas patogênicas ao homem (por exemplo, Burkholderia, Brucella, Bordetella, Enterococcus, Mycobacterium, Neisseria, Pseudomonas, Salmonella, Staphylococcus e Yersinia) (Stanley \& Saunders, 1996). Sondas IS's permitem obter informações sobre a estrutura e a evolução do genoma bacteriano. Estes contêm elementos móveis que estão envolvidos na evolução microbiana por criar mutações, deleções e recombinações, e por ativar genes crípticos ou por induzir a super expressão de genes contíguos do promotor interno do elemento IS (Stanley \& Saunders, 1996). A estabilidade no tempo do perfil obtido por análise de Southern com um IS como sonda deve ser avaliada com cuidado, haja vista que o valor epidemiológico de elementos IS como ferramentas de tipagem se baseia muito neste parâmetro (Pestel-Caron \& Arbeit, 1998). Embora IS's sejam elementos móveis, o evento de transposição pode ocorrer em baixas freqüências, e, conseqüentemente, os perfís obtidos serem estáveis durante um prolongado crescimento in vitro e in vivo (Bauer \& Andersen, 1999; Butcher et al.,1996; Hermans et al., 1991; Rastogi et al., 1992; Van Soolingen et al., 1991). A eficiência discriminatória de um elemento IS varia dependendo de sua habilidade de transposição dentro do genoma com alta ou baixa especificidade de seqüência alvo (Butcher et al., 1996).

Os elementos IS's também têm sido utilizados como sequêencias alvo para tipagem por PCR de Mycobacterium tuberculosis e Xanthomonas oryzae pv. oryzae, 
patógenos de humanos e arroz, respectivamente. Os métodos utilizados incluem a amplificação por PCR de seqüências de DNA que flanqueiam os elementos IS's, com ou sem restrição do produto amplificado a posteriori (PCR-RFLP), e ligação mediada por PCR (LMPCR) (George et al., 1997; Palittapongampim et al., 1993).

A genotipagem de isolados de Xanthomonas patogênicos em Citrus tem sido feita objetivando, preferencialmente, a diferenciação dos patovares existentes. Padrões obtidos pela clivagem do DNA por enzimas de restrição e reassociação de DNA demonstraram perfis similares entre os tipos A e B, è maiores diferenças destes dois grupos com o tipo E. A similaridade média entre estes três grupos foi de $60 \%$ por reassociação de DNA. Os cinco isolados testados pertencentes ao tipo A foram similares entre si no mínimo em 90\% (Egel et al., 1991). Resultados similares foram obtidos pela comparação dos perfis genéticos gerados por clivagem do DNA por enzimas de restrição e Southern blot (RFLP) usando-se como sonda um cluster do gene hrp (Leite Jr. et al., 1994). Relativo polimorfismo foi observado entre os grupos patogênicos de Xanthomonas, mas não dentro de cada patovar. Em outro estudo, a caracterização metabólica baseada na utilização do sistema Biolog não se correlacionou com a origem geográfica, hospedeiro e ano de isolamento (Vernière et al., 1993). Mais recentemente, a genotipagem de uma coleção mundial de isolados de Xac por BOX (BOX elements) e ERIC-PCR (enterobacterial repetitive intergenic consensus) permitiu a relativa caracterização de grupos genéticos e separou parcialmente isolados distantes geograficamente, como os originários da Ásia e América, e também os com patogenicidade diferenciada (tipos $\mathrm{A}^{*} \mathrm{e} \mathrm{A}^{\mathrm{W}}$ ). As similaridades médias encontradas entre os isolados de Xac estudados foram superiores a 85 e $87 \%$ para BOX e ERIC, respectivamente (Cubero \& Graham, 2002). Como sugerem os autores, a existência de genótipos comuns entre a Flórida e a América do Sul e Ásia, identificados por BOX e ERIC-PCR, pode ser em razão da introdução do patógeno na região metropolitana de Miami por material vegetal infectado (Graham et al., 2004). 


\section{ESCALAS DIAGRAMÁTICAS PARA AVALIAÇÃO DA SEVERIDADE DO CANCRO CÍTRICO}

\section{Resumo}

Escalas diagramáticas são importantes ferramentas na avaliação da severidade de doenças. Objetivando padronizar a estimativa da severidade do cancro cítrico em folhas, foram elaboradas quatro escalas diagramáticas, considerando a ocorrência de lesões isoladas pequenas (LP), médias (LM) e grandes (LG) e de lesões associadas com o ataque da larva minadora dos citros (LMC). Cada escala possui oito níveis de porcentagens da área foliar lesionada de 0,2 a 16\% para LP; 0,6 a 25\% para LM; 1,8 a $30 \%$ para LG e 0,5 a $30 \%$ para LMC. Inicialmente, seis avaliadores estimaram a severidade de 447 imagens digitalizadas de folhas sintomáticas com o auxílio das quatro escalas. Após treinamento, foram avaliadas mais 115 imagens. Regressões lineares entre as severidades real e estimada foram calculadas para cada avaliador. As escalas foram validadas conjuntamente considerando acurácia, precisão e reprodutibilidade das avaliações, revelando-se adequadas para quantificação da severidade de cancro cítrico.

\section{Summary}

\section{Diagrammatic Scales for Citrus Canker Severity Assessment}

Diagrammatic scales are important tools for disease severity assessment. Four diagrammatic scales for isolated small (SL), medium (ML), and large (LL) lesions and for symptoms associated with the leaf miner injuries (LM), were developed to 
standardize the severity assessments of citrus canker on leaves. Each scale has eight levels of disease severity (percentage of diseased leaf area): 0.2 to $16 \%$ for SL; 0.6 to $25 \%$ for ML; 1.8 to $30 \%$ for LL and 0.5 to $30 \%$ for LM. Initially, six raters evaluated the severity of 447 digitalized images of symptomatic leaves using all scales. A training was performed and after it, disease severity was assessed in 115 new images. Linear regressions between actual and estimated disease severity were calculated for each rater. The scales were validated considering the accuracy, precision and reproducibility of evaluations. The scales were adequate to quantify the severity of citrus canker on leaves.

\subsection{Introdução}

O cancro cítrico asiático, também denominado cancrose $\mathrm{A}$, é uma das mais graves doenças da cultura dos citros [Citrus sinensis (L.) Osb.]. Seu agente causal, a bactéria Xanthomonas axonopodis pv. citri [(Hasse) Vauterin et al.], encontra-se distribuído em dezenas de países localizados nos continentes oceânico, asiático e americano, infectando plantas da família Rutaceae (Civerolo, 1984). No Brasil, a primeira constatação foi em 1957, no município de Presidente Prudente, São Paulo (Bitancourt, 1957). Neste mesmo ano a doença foi encontrada nos Estados de Mato Grosso do Sul e Paraná (Amaral, 1957). Atualmente está presente nos Estados de São Paulo, Paraná, Santa Catarina, Rio Grande do Sul e Roraima (Barbosa et al., 2001; Nascimento et al., 2003; Porto et al., 1981).

O controle do cancro cítrico baseia-se principalmente em medidas de exclusão e erradicação e há medidas regulamentárias determinantes da erradicação de plantas e pomares quando afetados pela doença (Barbosa et al., 2001; Gottwald et al., 2001). Apesar das medidas de controle terem sido eficientemente empregadas durante décadas, a partir de 1996, com a introdução no Brasil da larva minadora dos citros (Phyllocnistis citrella Stainton - Lepdoptera: Gracillariidae: Phyllocnistinae) (Prates et al., 1996), houve um importante aumento na incidência do cancro cítrico em São Paulo, com conseqüências ainda não totalmente conhecidas para a citricultura paulista e brasileira (Bergamin Filho et al., 2000). 
Os sintomas constituem-se em lesões circulares, corticosas, salientes, de coloração amarronzada e aspecto eruptivo, ocorrendo em folhas, ramos e frutos (Bitancourt, 1957; Rossetti, 2001). Nas folhas e frutos é comum o aparecimento de um halo amarelo circundando a área necrosada. Em altas severidades pode ocorrer desfolha, queda de frutos e seca de ramos (Gottwald et al., 1988; Gottwald et al., 1989). Plantas cítricas afetadas constituem-se na principal fonte de inóculo da doença (Graham et al., 1987; Graham et al., 1989), já que a sobrevivência da bactéria é curta em qualquer outro substrato (Graham et al., 2000). A infecção ocorre em tecidos jovens (Goto, 1990; Graham et al., 1992), durante períodos de crescimento do hospedeiro (Lee, 1921).

A quantificação de doenças de plantas, ou patometria, é uma das mais importantes áreas da fitopatologia (James, 1974). Sua importância pode ser comparada até mesmo à etiologia, uma vez que conhecer o agente causal, mas não quantificar a extensão dos seus danos no hospedeiro, não faz muito sentido no que concerne à comparação e adoção de medidas de controle, epidemiologia, estudos da resistência e melhoramento genético, entre outros. Dois termos são comumente utilizados em fitopatometria: incidência e severidade, sendo o primeiro a porcentagem de plantas doentes, ou de partes de plantas doentes, e o segundo a proporção do volume ou da área do tecido com sintomas (Amorim, 1995; James, 1974). A quantificação de uma doença por incidência é mais fácil, precisa e simples. A avaliação da severidade exige a adoção de chaves descritivas, escalas diagramáticas ou a análise de imagens digitalizadas por programas computacionais. Destas três, as escalas diagramáticas são as mais utilizadas atualmente e constituem-se em representações ilustradas de uma série de plantas ou de partes de plantas com sintomas em diferentes níveis de severidade.

Severidade é a variável mais apropriada na quantificação do cancro cítrico, uma vez que reflete mais acuradamente o progresso da doença que a incidência (Gottwald et al., 1989), além de estar associada aos danos na produção. A elaboração de uma escala diagramática exige a adoção de três critérios básicos: a) os limites superior e inferior da escala devem corresponder às quantidades máxima e mínima, respectivamente, de doença observadas no campo; b) as imagens da escala devem ser representativas dos sintomas observados sob infecção natural; c) os níveis da escala 
devem respeitar as limitações da acuidade visual humana, segundo a Lei de WeberFechner, que determina que a acuidade visual é proporcional ao logaritmo da intensidade do estímulo (Amorim, 1995). Segundo este último critério, os níveis de uma escala diagramática devem crescer exponencialmente, até o limite máximo de $50 \%$.

Os objetivos do presente trabalho foram a elaboração e a validação de escalas diagramáticas para a avaliação da severidade do cancro cítrico em folhas, considerando a existência de lesões isoladas pequenas, médias e grandes, e de lesões associadas à injúria causada pela larva minadora dos citros.

\subsection{Material e métodos}

Quatrocentos e quarenta e sete folhas com sintomas de cancro cítrico, coletadas em diferentes municípios do Estado de São Paulo, foram utilizadas para elaboração e validação das escalas diagramáticas. Todas as folhas tiveram suas imagens digitalizadas e a porcentagem da área foliar sintomática foi determinada no programa Acess ${ }^{\circledR}$. Os limites mínimo e máximo de severidade encontrados para todas as folhas avaliadas foram 0,2 e $30,0 \%$, respectivamente. A partir destes limites e considerando que foram encontrados sintomas da doença em lesões isoladas de diferentes tamanhos e também associadas à injúria da larva minadora dos citros, foram elaboradas no programa CorelDraw $7^{\circledR}$ quatro escalas diagramáticas, três delas para lesões isoladas de tamanhos pequeno, médio e grande e uma quarta escala para lesões coalescentes simulando a associação dos sintomas de cancro cítrico à injúria da larva minadora.

A validação das escalas foi feita em duas fases: sem e com treinamento prévio. $\mathrm{Na}$ primeira, seis avaliadores estimaram a severidade das 447 imagens de folhas com cancro cítrico com o auxílio das quatro escalas diagramáticas. Na segunda fase, um arquivo em Power Point ${ }^{\circledR}$ com 150 imagens de folhas doentes foi utilizado para o treinamento dos avaliadores que puderam observar imagens de folhas sintomáticas sem a indicação da severidade real, num primeiro slide, e com a severidade real indicada no slide seguinte. Logo após este treinamento, os mesmos seis avaliadores estimaram a 
severidade de outras 115 imagens, da mesma forma como conduzido na primeira avaliação.

Para cada avaliador foi calculada a regressão linear entre a severidade real (variável independente) e a severidade estimada (variável dependente) antes e após o treinamento seguindo a metodologia descrita por Draper \& Smith (1998) e Teng (1981). $\mathrm{O}$ conjunto de dados de todos avaliadores foi utilizado para o cálculo da regressão linear antes e após o treinamento. Os parâmetros interseção da reta $(a)$ e coeficiente angular $(b)$ de cada regressão linear foram comparados pelo teste $t(p=0,05)$ com os valores 0 e 1 , respectivamente, para a aferição da acurácia de cada avaliador individualmente, e também de todos avaliadores, antes e após o treinamento. A precisão dos avaliadores foi obtida pelos coeficientes de determinação da regressão $\left(R^{2}\right)$ e pela distribuição dos resíduos (severidade real - estimada) (Campbell \& Madden, 1990; Kranz, 1988; Nutter Júnior \& Schultz, 1995). O melhor avaliador em cada etapa também foi comparado com os demais avaliadores para a aferição da reprodutibilidade das escalas.

\subsection{Resultados e discussão}

A escala que representa as lesões pequenas de cancro cítrico (Figura 1A) possui os níveis de severidade 0,$2 ; 0,5 ; 1,1 ; 1,9 ; 3,3 ; 5,8 ; 9,8$ e $16,0 \%$. Para lesões de tamanho médio (Figura 1B) os níveis são 0,$6 ; 1,3 ; 2,5 ; 4,1 ; 6,7 ; 10,6 ; 16,7$ e 25,0\%. Na representação de folhas com lesões grandes (Figura 1C) os níveis presentes na escala são 1,$8 ; 3,2 ; 5,5 ; 8,0 ; 11,5 ; 16,2 ; 22,3$ e 30,0\%. Para folhas com lesões de cancro cítrico associadas com a injúria provocada pelo minador dos citros (Figura 1D) os níveis da escala são 0,$5 ; 1,2 ; 2,6 ; 4,4 ; 7,5 ; 12,4 ; 19,7$ e $30,0 \%$.

A avaliação da severidade do cancro cítrico em folhas com o auxílio das escalas diagramáticas foi realizada com relativa acurácia e precisão por diferentes avaliadores mesmo antes de qualquer treinamento. Três avaliadores apresentaram coeficientes angulares $(b)$ estatisticamente iguais a um (Tabela 1 e Figura 2) e três apresentaram o parâmetro de interseção da reta $(a)$ estatisticamente igual a zero. Três avaliadores apresentaram coeficientes de determinação $\left(R^{2}\right)$ superiores a 0,80 . 


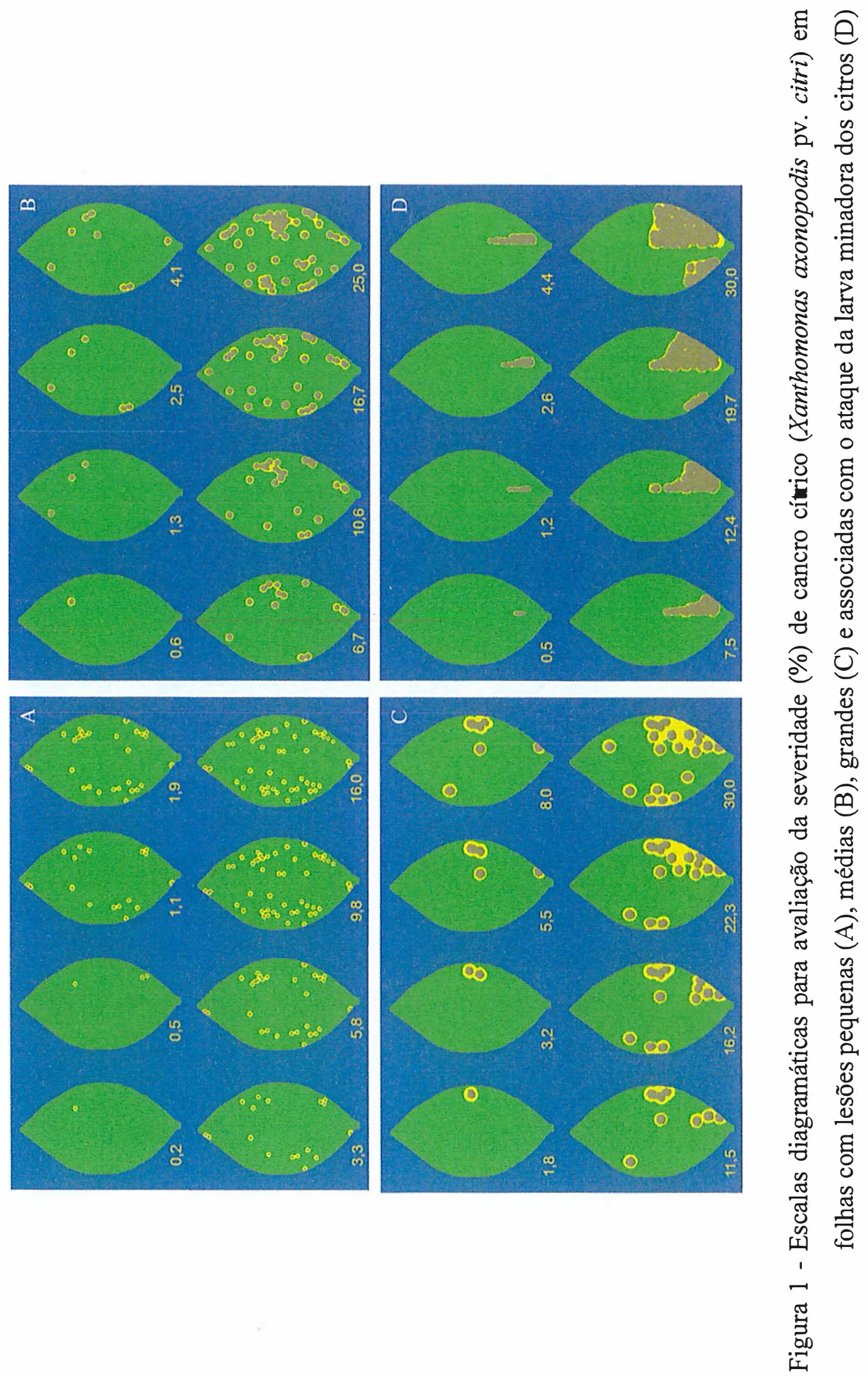


Tabela 1 - Estimativas da interseção da reta $(a)$ e do coeficiente angular $(b)$ e coeficientes de determinação $\left(R^{2}\right)$ das equações de regressão linear calculadas entre as severidades real e estimada de cancro cítrico realizadas por seis avaliadores individualmente e para o conjunto dos mesmos, antes e após treinamento $(y=a+b x$, em que $y$ representa a severidade estimada e $x$, a severidade real)

\begin{tabular}{ccccccc}
\hline Avaliador & \multicolumn{3}{c}{ Antes do treinamento } & \multicolumn{3}{c}{ Após o treinamento } \\
& $a^{\text {(i) }}$ & $b^{\text {(ii) }}$ & $R^{2}$ & $a$ & $b$ & $R^{2}$ \\
1 & $0,52^{*}$ & $0,45^{*}$ & 0,65 & $0,70^{*}$ & $0,87^{*}$ & 0,90 \\
2 & $1,58^{*}$ & $0,93^{*}$ & 0,76 & $1,14^{*}$ & $0,73^{*}$ & 0,82 \\
3 & $-0,03^{\mathrm{NS}}$ & $0,88^{*}$ & 0,88 & $0,53^{*}$ & $0,75^{*}$ & 0,88 \\
4 & $-0,10^{\mathrm{NS}}$ & $1,03^{\mathrm{NS}}$ & 0,85 & $0,56^{*}$ & $0,85^{*}$ & 0,86 \\
5 & $0,05^{\mathrm{NS}}$ & $1,01^{\mathrm{NS}}$ & 0,88 & $0,62^{*}$ & $0,94^{\mathrm{NS}}$ & 0,88 \\
6 & $1,79^{*}$ & $0,97^{\mathrm{NS}}$ & 0,68 & $0,81^{*}$ & $0,98^{\mathrm{NS}}$ & 0,84 \\
Todos & $0,63^{*}$ & $0,88^{*}$ & 0,71 & $0,73^{*}$ & $0,85^{*}$ & 0,84 \\
\hline
\end{tabular}

(i) asterisco indica que o valor da interseção da reta $(a)$ foi diferente de zero pelo teste $t(p=0,05)$, ns indica que não houve diferença estatística significativa entre $a$ e zero pelo teste $t(p=0,05)$;

(ii) asterisco indica que o valor do coeficiente angular da reta de regressão $(b)$ foi diferente de um pelo teste $t(p=0,05)$, ns indica que não houve diferença estatística significativa entre $b$ e um pelo teste $t(p=$ 0,05).

Nutter Júnior et al. (1991) explicam que precisão é a medida de confiabilidade nas avaliações de uma doença, podendo ser quantificada pelo coeficiente de determinação de regressões lineares estabelecidas entre as severidades real e estimada. Quanto maiores os valores do $R^{2}$, mais preciso é o avaliador. Por outro lado, a acurácia revela o quanto a severidade real está próxima da estimativa média realizada pelo avaliador. Sua quantificação pode ser feita pela comparação dos valores da interseção da reta (a) e do coeficiente angular (b), obtidos nos cálculos de regressão linear entre as severidades real e estimada, com os valores 0 e 1, respectivamente. A situação ideal, 
neste caso, é representada pelo avaliador que apresente valores de $(a)$ e $(b)$ iguais a 0 e 1 , respectivamente, revelando que as estimativas de severidade foram iguais às severidades reais $(\mathrm{y}=\mathrm{x}$ quando $a=0$ e $b=1)$.
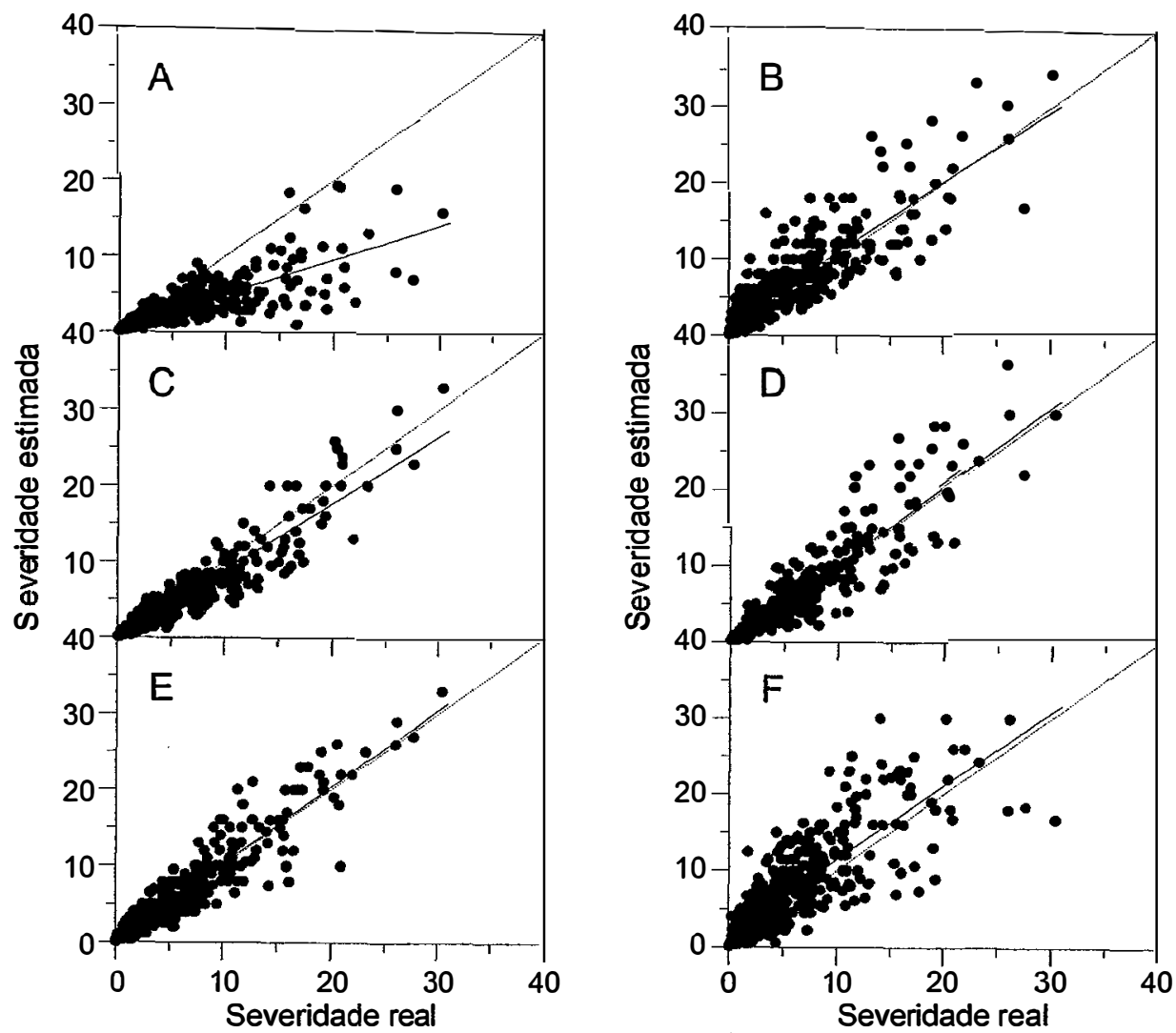

Figura 2 - Severidade de cancro cítrico estimada pelos avaliadores 1 (A), 2 (B), 3 (C), 4 (D), 5 (E) e 6 (F) sem treinamento prévio. A linha cheia representa a regressão linear entre a severidade real e a estimada, enquanto a linha tracejada representa a situação ideal $(y=x)$

Outra forma de quantificar a precisão dos avaliadores é a observação da distribuição dos resíduos na qual a subtração (severidade real - estimada) é a variável dependente e a severidade real, a independente (Campbell \& Madden, 1990; Kranz, 1988; Nutter Júnior \& Schultz, 1995). Os menores vieses das estimativas da severidade do cancro ocorreram para severidades inferiores a 10\% (Figura 3), independentemente 
dos avaliadores. Os avaliadores mais precisos foram o três e o cinco, que apresentaram distribuições mais homogêneas dos resíduos, além de elevados coeficientes de determinação. Os valores mínimo e máximo observados para o resíduo foram - 20,6 e 16,0 , respectivamente.
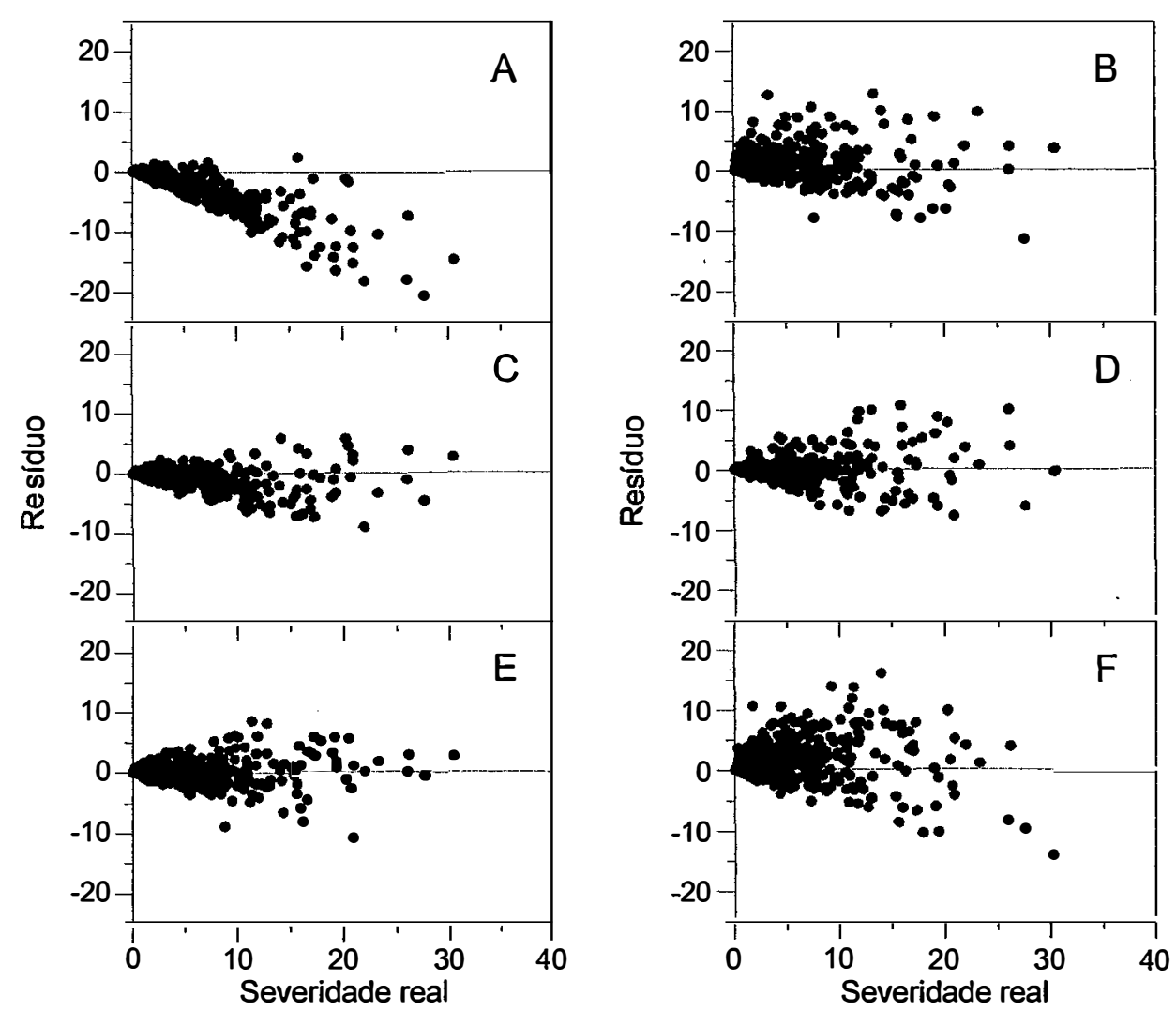

Figura 3 - Distribuição dos resíduos das análises de regressão linear entre as severidades real e estimada pelos avaliadores 1 (A), 2 (B), 3 (C), 4 (D), 5 (E) e 6 (F) sem treinamento prévio

A reprodutibilidade das escalas foi testada comparando-se o melhor avaliador com os demais. Apesar da ocorrência de relativa precisão, demonstrada por coeficientes de determinação de 0,65 a 0,85 , somente na comparação dos avaliadores quatro e cinco a interseção da reta foi estatisticamente igual a zero (Tabela 2 e Figura 4). Em todas as 
Tabela 2 - Estimativas da interseção da reta $(a)$ e do coeficiente angular $(b)$ e coeficientes de determinação $\left(R^{2}\right)$ das equações de regressão linear calculadas entre as severidades estimadas por diferentes avaliadores em comparação com o avaliador $5(y=a+b x$, em que $y$ representa a severidade estimada por um dos avaliadores e $x$ a severidade estimada pelo avaliador 5). As estimativas da severidade dos seis avaliadores foram confrontadas entre si, antes e após o treinamento dos avaliadores

\begin{tabular}{ccccccc}
\hline $\begin{array}{c}\text { Comparação entre } \\
\text { avaliadores }\end{array}$ & \multicolumn{3}{c}{ Antes do treinamento } & \multicolumn{3}{c}{ Após o treinamento } \\
\hline & $a^{\text {(i) }}$ & $b^{\text {(ii) }}$ & $R^{2}$ & $a$ & $b$ & $R^{2}$ \\
1 vs. 5 & $0,63^{*}$ & $0,42^{*}$ & 0,65 & $0,50^{\mathrm{NS}}$ & $0,85^{*}$ & 0,85 \\
2 vs. 5 & $1,81^{*}$ & $0,86^{*}$ & 0,77 & $0,84^{*}$ & $0,74^{*}$ & 0,84 \\
3 vs. 5 & $0,27^{\mathrm{NS}}$ & $0,81^{*}$ & 0,85 & $0,34^{\mathrm{NS}}$ & $0,74^{*}$ & 0,84 \\
4 vs. 5 & $0,32^{\mathrm{NS}}$ & $0,92^{\mathrm{NS}}$ & 0,80 & $0,45^{\mathrm{NS}}$ & $0,82^{*}$ & 0,78 \\
6 vs. 5 & $2,00^{*}$ & $0,90^{*}$ & 0,70 & $0,41^{\mathrm{NS}}$ & $1,00^{\mathrm{NS}}$ & 0,85 \\
\hline
\end{tabular}

(i) asterisco indica que o valor da interseção da reta $(a)$ foi diferente de zero pelo teste $t(p=0,05)$, ns indica que não houve diferença estatística significativa entre $a$ e zero pelo teste $t(p=0,05)$;

(ii) asterisco indica que o valor do coeficiente angular da reta de regressão $(b)$ foi diferente de um pelo teste $t(p=0,05)$, ns indica que não houve diferença estatística significativa entre $b$ e um pelo teste $t(p=$ $0,05)$.

demais comparações os coeficientes angulares diferiram de um. Os mesmos avaliadores que estimaram a severidade de 447 imagens de folhas sintomáticas foram treinados e, numa segunda etapa, estimaram a severidade de 115 imagens. Este treinamento foi utilizado como tentativa de melhorar as estimativas dos diferentes avaliadores. De fato, estimativas mais precisas foram observadas para os seis avaliadores, já que os valores dos coeficientes de determinação aumentaram, variando de 0,82 a 0,90 (Tabela 1 e Figura 5). O treinamento dos avaliadores foi essencial no desempenho daqueles de menor precisão, como no caso do avaliador 1 (Tabela 1). A distribuição dos resíduos também melhorou após o treinamento, ocorrendo um aumento na homogeneidade da distribuição dos valores (Figura 6). Os valores mínimo e máximo observados foram - 6,9 

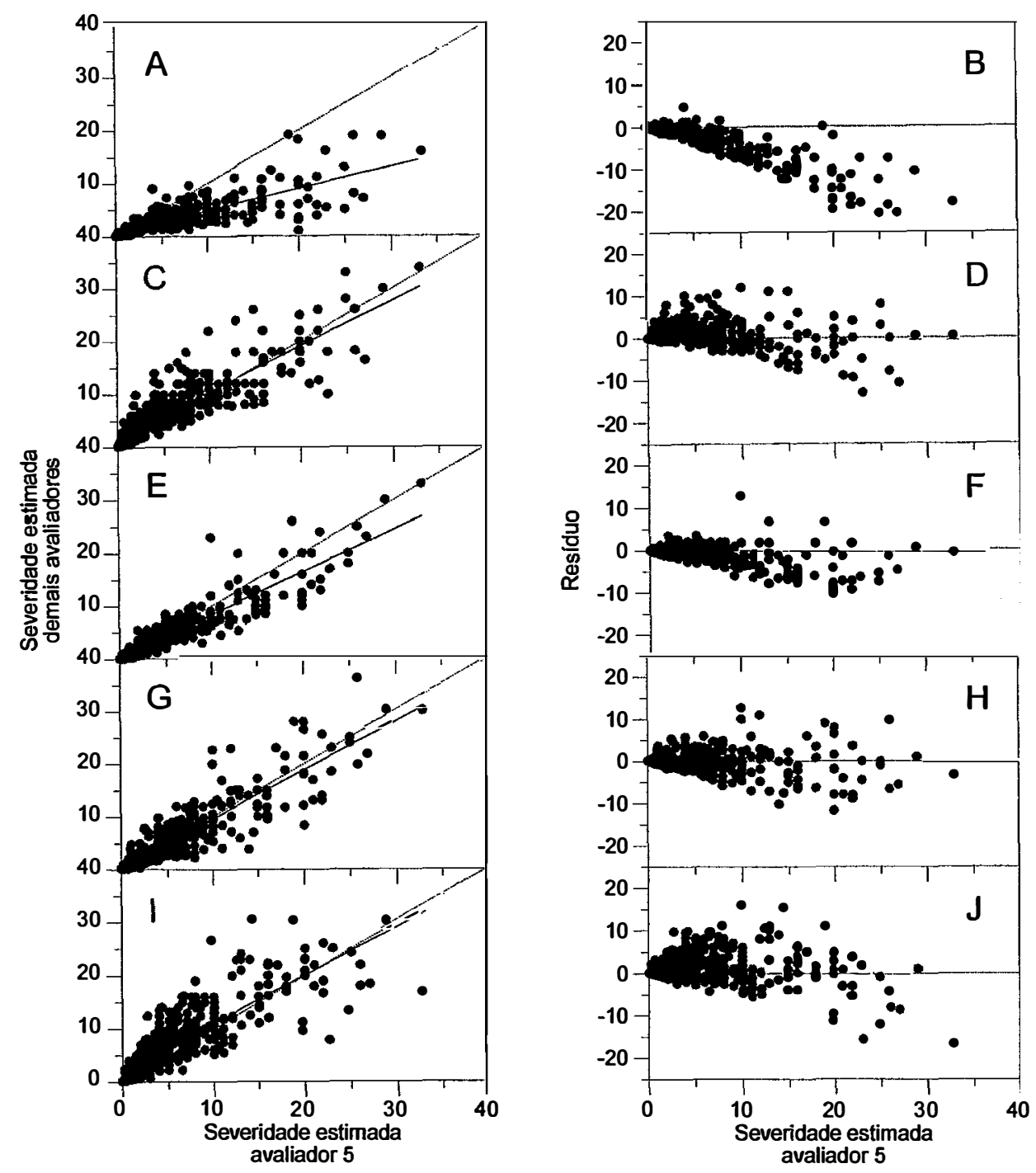

Figura 4 - Regressões lineares e distribuição dos resíduos na comparação do avaliador 5 com os avaliadores 1 (A, B), 2 (C, D), $3(\mathrm{E}, \mathrm{F}), 4(\mathrm{G}, \mathrm{H})$ e 6 (I, J) sem treinamento prévio. A linha cheia representa a regressão linear entre as estimativas dos avaliadores enquanto a linha tracejada representa a situação ideal $(y=x)$

e 9,1, respectivamente, estando agora dentro de um intervalo aceitável $(-10,0$ e $+10,0)$ segundo critérios adotados por programas de treinamento na quantificação de doenças, como o Distrain (Tomerlin \& Howell, 1988) e o Disease.Pro (Nutter Júnior \& 
Worawitlikit, 1989). Em relação a acurácia, dois avaliadores apresentaram o coeficiente angular estatisticamente igual a um. Em todas as avaliações os valores da interseção foram diferentes de zero.
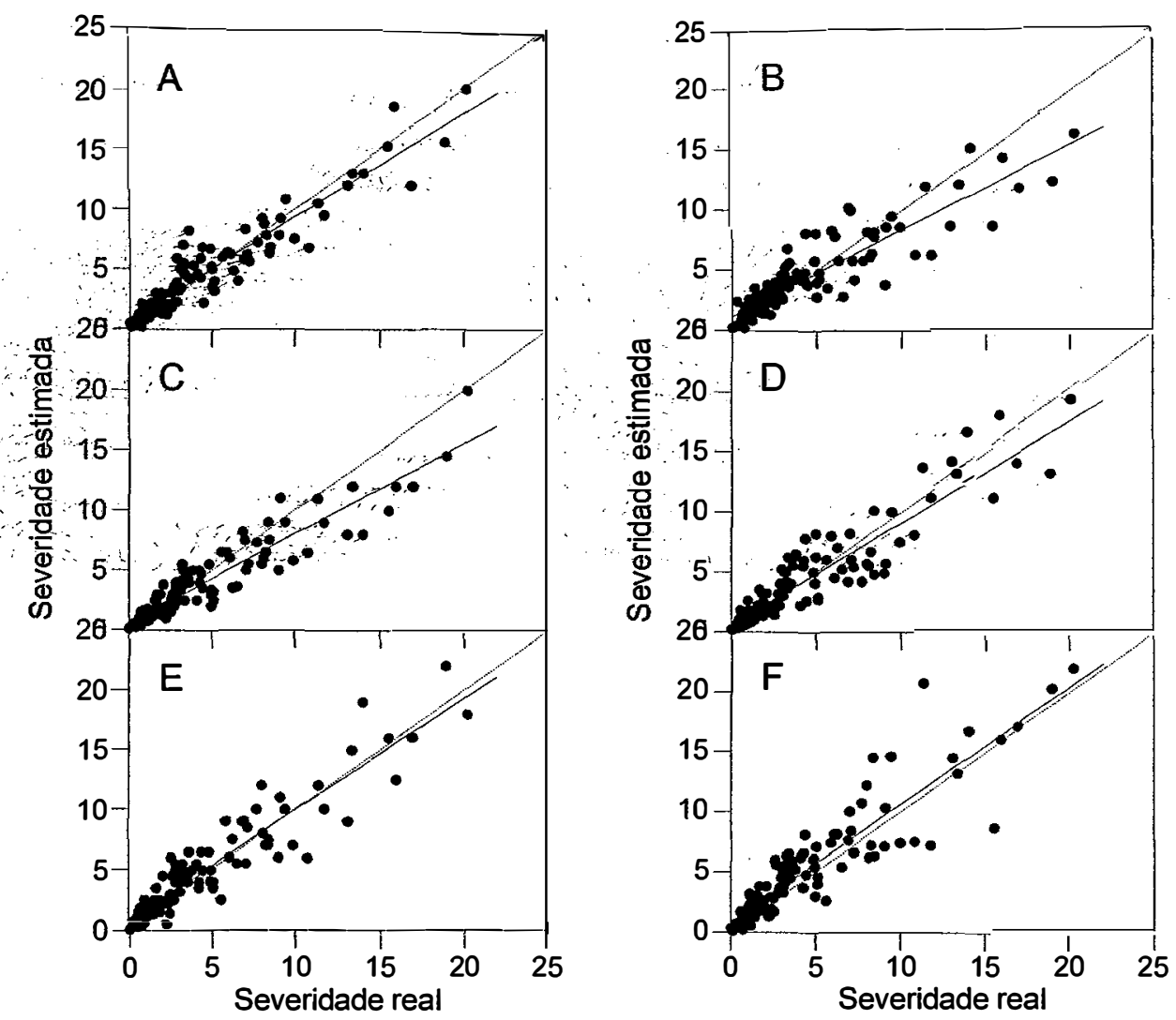

Figura 5 - Severidade estimada pelos avaliadores 1 (A), 2 (B), 3 (C), 4 (D), 5 (E) e 6 (F) após treinamento. A linha cheia representa a regressão linear entre a severidade real e a estimada, enquanto a linha tracejada representa a situação ideal $(y=x)$

Como observado antes do treinamento, o melhor avaliador continuou sendo o avaliador cinco, tendo sido comparado com os demais para estimar a reprodutibilidade das escalas. Quatro das cinco comparações tiveram valores da interseção da reta estatisticamente iguais a zero (Tabela 2). Na comparação dos avaliadores cinco e seis foi encontrado valor de $(b)$ estatisticamente igual a um. Com exceção das comparações 
entre os avaliadores três e cinco e quatro e cinco, em todas as demais foram encontrados coeficientes de determinação superiores aos observados antes do treinamento. Distribuições mais adequadas dos resíduos também foram observadas após o treinamento dos avaliadores (Figura 7).
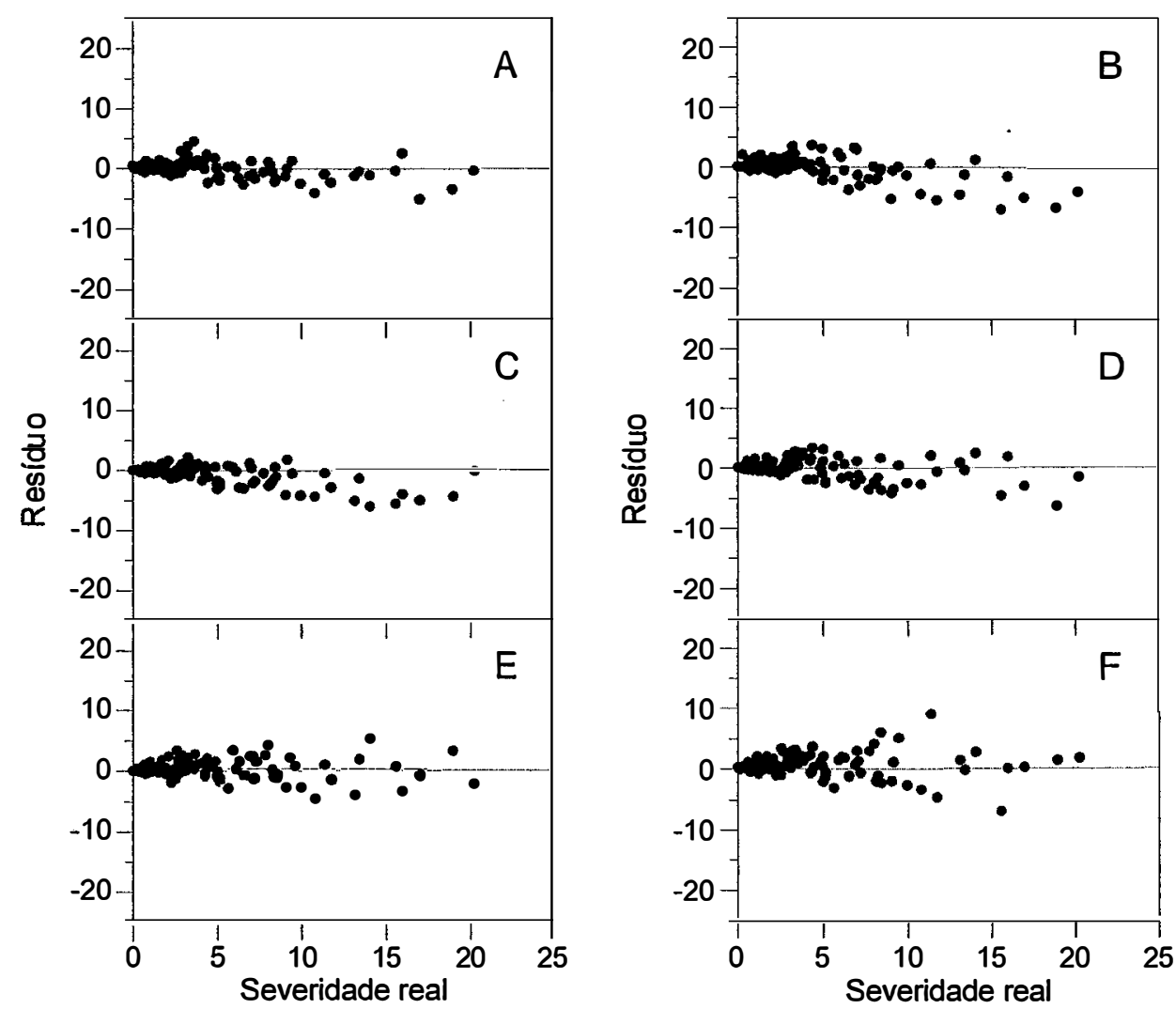

Figura 6. - Distribuição dos resíduos das análises de regressão linear entre as severidade real e estimada pelos avaliadores 1 (A), 2 (B), 3 (C), 4 (D), 5 (E) e 6 (F) após treinamento

Considerando as avaliações de todos avaliadores antes do treinamento, os valores de $(a)$ e $(b)$ foram 0,63 e 0,88 , respectivamente, ambos diferindo estatisticamente de 0 e 1 (Tabela 1 e Figura 8). O coeficiente de determinação encontrado foi 0,71. Da mesma forma, após o treinamento, os valores de $(a)$ e $(b)$ continuaram diferindo de 0 e 1 , 
respectivamente, mas um maior coeficiente de determinação foi encontrado $(0,84)$, em razão da maior precisão dos avaliadores após o treinamento.
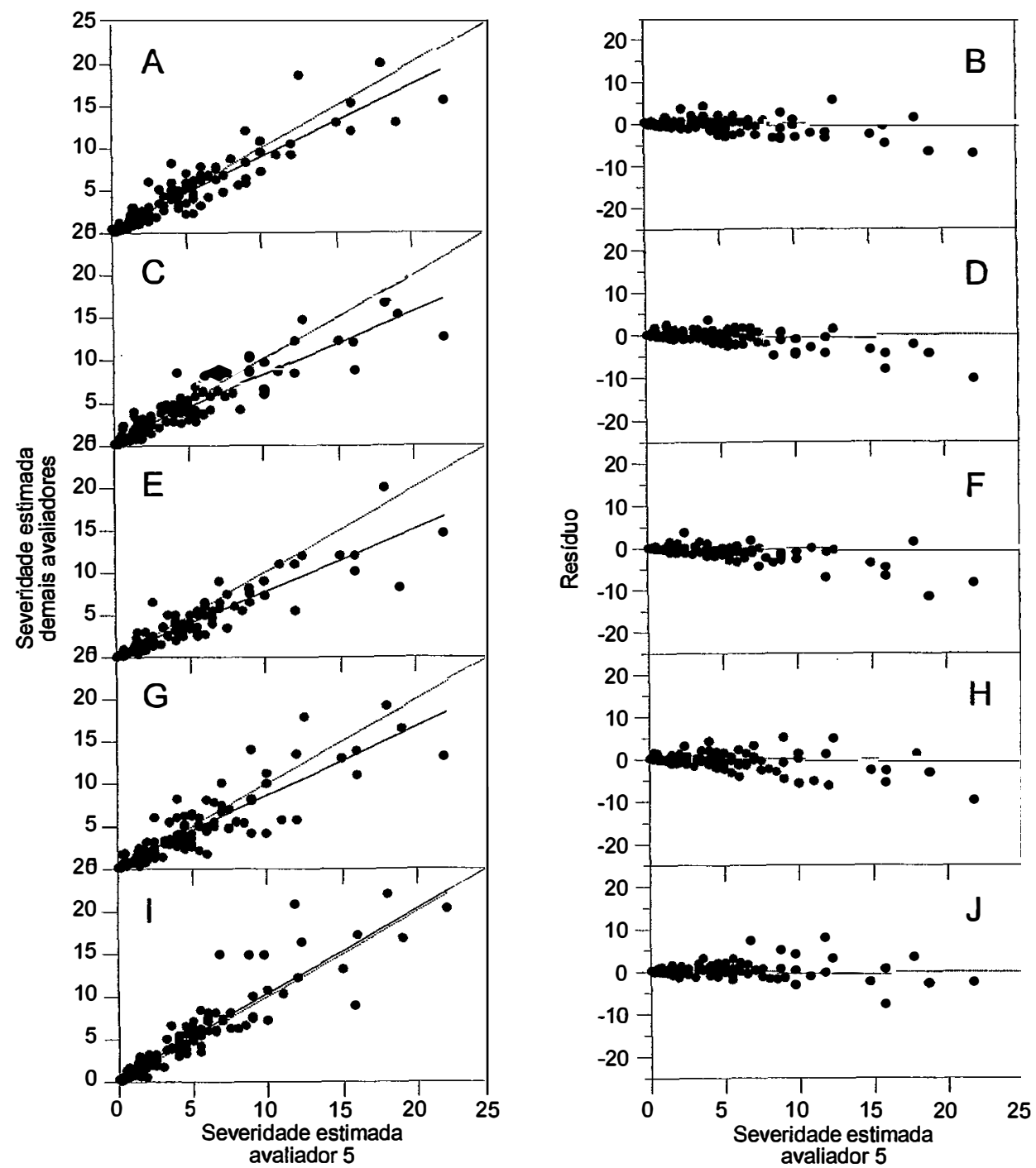

Figura 7 - Regressão linear e distribuição dos resíduos na comparação do avaliador 5 com os avaliadores $1(\mathrm{~A}, \mathrm{~B}), 2(\mathrm{C}, \mathrm{D}), 3(\mathrm{E}, \mathrm{F}), 4(\mathrm{G}, \mathrm{H})$ e 6 (I, J) após treinamento. A linha cheia representa a regressão linear entre as estimativas dos avaliadores enquanto a linha tracejada representa a situação ideal $(y=x)$

As escalas desenvolvidas permitiram avaliações suficientemente acuradas e precisas, ficando a critério do avaliador a escolha da escala a ser utilizada no momento 
da avaliação. O treinamento dos avaliadores permitiu o aumento da precisão das estimativas, tendo sido observado aumentos dos coeficientes de determinação e distribuições mais homogêneas dos resíduos. Comparando-se o melhor avaliador com os demais, após o treinamento, as estimativas de diferentes avaliadores ficaram mais próximas ou semelhantes, indicando que o uso das escalas produz quantificações reprodutíveis.
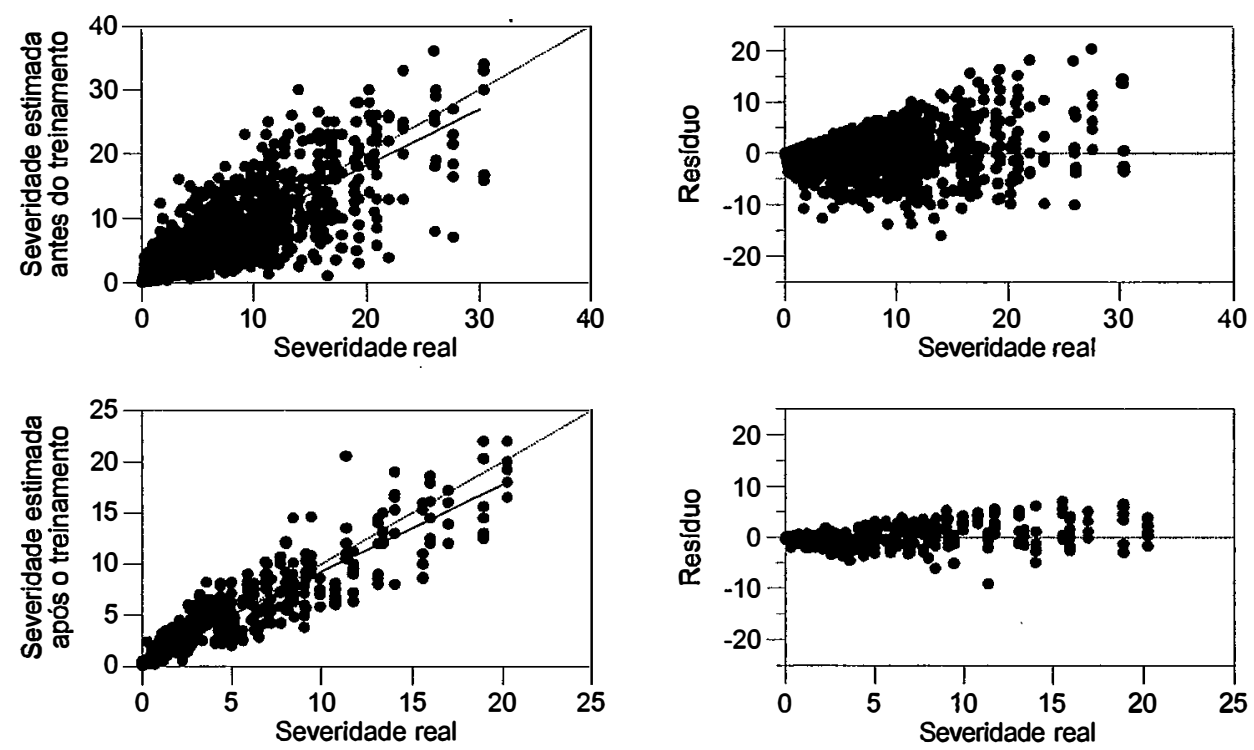

Figura 8 - Regressão linear e distribuição dos resíduos considerando todo o conjunto de dados antes e após o treinamento dos avaliadores. A linha cheia representa a regressão linear entre as severidades real e estimada enquanto a linha tracejada representa a situação ideal $(y=x)$

Em razão da disseminação da bactéria, na mesma planta e entre plantas em um mesmo local, ocorrer principalmente pela ação de respingos de chuvas e chuvas associadas com ventos, a incidência de folhas e de ramos sintomáticos pode não ser homogênea na mesma planta, isto sendo influenciado por condições ambientais e do hospedeiro (Danós et al., 1984; Gottwald et al., 1988; Gottwald et al., 1989; Gottwald et al., 1997a). Como exemplo, Palazzo et al. (1984) verificaram maior incidência de folhas sintomáticas nos quadrantes norte e oeste de plantas cítricas, lados estes expostos ao 
ventos predominates da região.

A associação da maior suscetibilidade dos tecidos quando jovens, a emissão de fluxos vegetativos na primavera/verão e a disseminação do patógeno principalmente por chuvas com ventos faz com que o cancro cítrico tenha um caráter cíclico, no tocante à ocorrência de novas infecções pela doença (Gottwald et al., 1988; Gottwald et al., 1989). Gottwald et al. (1989) observaram flutuações na severidade da doença ao longo do tempo, o mesmo não tendo ocorrido para incidência. Apesar disso, em razão da sobrevivência da bactéria ser maior em tecidos infectados do hospedeiro, sintomas da doença são encontrados ao longo de todo ano (Peltier \& Neal, 1918; Pruvost et al., 2002). Sugere-se, portanto, na avaliação de plantas doentes, a escolha de ramos em diferentes lados da mesma planta e a quantificação da doença nas folhas desses ramos. 


\section{AUSÊNCIA DA PROPAGAÇÃO DO CANCRO CÍTRICO (Xanthomonas axonopodis PV. citri) POR ADULTOS DA LARVA MINADORA DOS CITROS (Phyllocnistis citrella)}

\section{Resumo}

Após a introdução da larva minadora dos citros nas duas maiores áreas produtoras de citros do mundo - Brasil e Estados Unidos, o estudo da interação desse inseto com o cancro cítrico voltou a fazer parte das linhas de pesquisa de entomologistas e fitopatologistas. Um maior número de plantas doentes foi detectado nesses países e os sintomas da doença passaram a ser observados associados com as injúrias do inseto. Os experimentos aqui apresentados objetivaram o estudo da propagação do cancro cítrico por adultos da larva minadora de duas maneiras: após a oviposição por adultos desenvolvidos em plantas doentes e durante o livre acesso de adultos a plantas doentes e sadias. Em nenhum dos experimentos instalados foram observadas plantas sintomáticas após a oviposição ou contato dos insetos. Três outros experimentos foram conduzidos objetivando a detecção do transporte e, em um deles, a deposição de Xanthomonas axonopodis pv. citri por adultos da larva minadora. Da mesma maneira, não foram observados o transporte e a disseminação do patógeno. Esses resultados indicam que a propagação do cancro cítrico exclusivamente por adultos da larva minadora não deve ser um evento ocorrente na natureza e, portanto, não possui importância epidemiológica sob condições naturais de infecção.

\section{Summary}


Lack of Citrus Canker (Xanthomonas axonopodis pv. citri) Spread by Adults of Citrus Leafminer (Phyllocnistis citrella)

In the last years a question about the interaction between citrus leafminer and citrus canker emerges after the introduction of this pest in the two most important citrus producting areas - Brazil and United States. A high number of diseased plants were detected in these countries and many symptoms now occur in the miner caused by the pest. Experiments presented here were conduct to study the spread of the citrus canker by adults of leafminer by two ways: during the oviposition in test plants by adults developed in diseased plants and during the free access of adults to diseased and health plants. In none of these trials symptoms occurred in the test plants. Three trials were also conducted to observe the transport and, in one of them, the deposition of Xanthomonas axonopodis pv. citri by adults of leafminer. In the same way, in none of these trials dispersal of the bacteria were observed. These results indicate that the spread of citrus canker exclusively by citrus leafminer are not a frequent event in nature and has no epidemiological importance under natural infection conditions.

\subsection{Introdução}

O minador-dos-citros, Phyllocnistis citrella Stainton, 1856 (Lepidoptera, Gracillariidae) é originário da Ásia e encontra-se distribuído nos cinco continentes (Achor et al., 1996; Heppner, 1993; Prates et. al., 1996). No Brasil, foi introduzido em 1996, na região sul do Estado de São Paulo (Prates et. al., 1996). O adulto é uma pequena mariposa de aproximadamente $4,0 \mathrm{~mm}$ de envergadura, com asas anteriores de coloração branca a prata brilhantes, plumosas, apresentando um ponto preto na região apical, característico da espécie (Garijo \& Garcia, 1994; Heppner, 1993; Smith \& Hoy, 1995). A oviposição é realizada em folhas novas (brotações) de citros e as lagartas ao eclodirem penetram no mesofilo foliar, provocando galerias típicas em forma de serpentina, causando a atrofia do tecido foliar, o qual assume uma coloração prateada, surgindo posteriormente, manchas necróticas, culminando com a seca destas estruturas 
(Chagas \& Parra, 2000). Além do comprometimento à fotossíntese, os danos provocados pela praga podem resultar na queda prematura das folhas e impedir o desenvolvimento das brotações, refletindo conseqüentemente no potencial produtivo do pomar (Badawy, 1967; Clausen, 1931; Heppner, 1993; Prates et. al., 1996).

Os hábitos dessas larvas favorecem também a entrada de microrganismos patogênicos nos tecidos vegetais, principalmente a bactéria Xanthomonas axonopodis pv. citri (Xac), causadora do cancro cítrico. Trata-se de uma doença quarentenária, estando o comércio de frutos cítricos sob a influência de legislações rígidas nas principais zonas exportadoras do mundo (Civerolo, 1985; Gottwald et al., 2001; Schoulties et al., 1987). Os sintomas da doença são lesões necróticas, corticosas, geralmente com um halo amarelo ao redor quando em folhas e frutos. Além destes, os ramos podem também ser infectados (Stall \& Seymour, 1983; Schoulties et al., 1987). O principal meio de disseminação em condições naturais é quando da ocorrência de chuvas associadas com ventos. A disseminação a longa distância ocorre pelo transporte de materiais vegetais infectados. Atividades culturais como poda, colheita e pulverizações podem disseminar a bactéria entre plantas de um mesmo pomar (Civerolo, 1985; Danós et al., 1984; Gottwald et al., 1988).

Após a introdução desta praga no Brasil o número de casos da doença aumentou drasticamente (Gimenes-Fernandes et al., 2000). O mesmo foi observado em outros países, como nos Estados Unidos (Gottwald et al., 1997b). Levantamentos realizados no Yemen revelaram a ocorrência de folhas infectadas com a doença associadas com danos desta praga. As pústulas de cancro cítrico desenvolveram-se, geralmente, somente em um dos lados das folhas, sobre as galerias provocadas pelo minador. Na maioria das vezes, essas lesões estavam na página inferior das folhas (Cook, 1988). Amostragens em laranja doce, realizadas na Índia, revelaram que 48,35\% das folhas com danos de minador apresentaram também lesões de cancro cítrico. Por outro lado, apenas $3,18 \%$ das folhas sem danos do minador apresentavam lesões de cancro cítrico (Venkateswarlu \& Ramapandu, 1992). Os autores também avaliaram o número de lesões de cancro/folha e sua relação com a ocorrência do inseto. $\mathrm{O}$ número 
médio de lesões de cancro foi de 3,39/folha, em folhas com danos do minador, e de 1,36 para folhas livres de danos da praga.

Embora a bactéria penetre as folhas via estômatos, a taxa de infecção em folhas lesionadas pelo minador pode ser onze vezes maior em comparação com folhas intactas (Chagas at al., 2001). Nestes estudos não foi avaliada a disseminação desta bactéria por adultos de $P$. citrella. Apesar da relação existente entre o cancro cítrico e a praga já ser conhecida (Cook, 1988; Sohi \& Sandhu, 1968; Venkateswarlu \& Ramapandu, 1992), permanece obscuro ainda de que forma exatamente o minador tornase responsável por aumentos na incidência/severidade da doença (Chagas et al., 2001; Graham et al., 1996).

O objetivo deste trabalho foi verificar a propagação do cancro cítrico por adultos do minador, uma vez que até o presente momento não existem comprovações de que o adulto seja vetor da bactéria, embora já se conheça a associação da doença com os danos causados pelas fases imaturas do inseto.

\subsection{Material e métodos}

Trinta e sete experimentos foram conduzidos para verificação da propagação do cancro cítrico por adultos do minador. Outros três experimentos foram conduzidos para verificar o transporte/deposição da bactéria por adultos com acesso a plantas doentes. As condições de temperatura e fotofase foram de $28 \pm 1^{\circ} \mathrm{C}$ e 14 horas, respectivamente. Foram utilizadas plantas de limão cravo (Citrus limonia L. Osbeck), com aproximadamente 25 a $30 \mathrm{~cm}$ de altura, cultivadas em tubetes plásticos com dimensões de $20 \mathrm{~cm}$ de altura e $1,5 \mathrm{~cm}$ de diâmetro e preenchidos com substrato de vermiculita e composto vegetal (1:1). Para a inoculação das plantas foram utilizadas suspensões bacterianas em água destilada obtidas de colônias da estirpe IBSBF 1450, resistente ao antibiótico rifampicina. As inoculações foram realizadas com suspensões de aproximadamente $10^{7}$ unidades formadoras de colônia (UFC)/mL. Os quarenta experimentos foram divididos em três grupos e para melhor compreensão estão descritos a seguir, separadamente: 


\subsubsection{Propagação do cancro cítrico por adultos da larva minadora desenvolvidos em plantas doentes}

Dezenove experimentos foram conduzidos sequencialmente, tendo sido numerados de 1 a 19. Para cada experimento foram utilizadas quarenta plantas de limão cravo (plantas fonte) com ovos e lagartas de primeiro ínstar do minador e inoculadas por imersão das cinco primeiras folhas das plantas em suspensão bacteriana.

As plantas foram mantidas no interior de caixas de poliestireno e alumínio, com dimensões de $60 \times 40$ centímetros e 50 centímetros de altura, com duas portas laterais, uma de cada lado da caixa, para o manuseio das plantas, e uma tela anti-afídeo na parte posterior. As quarenta plantas inoculadas permaneceram na posição vertical, em grades metálicas, colocadas sobre uma bandeja de isopor com água. Após a inoculação, uma capa plástica foi colocada na parte posterior das caixas, para formação de câmara úmida, a fim de se obter melhores condições para infecção das plantas. Neste período a umidade relativa do ar, no interior das caixas, variou de 90 a $95 \%$.

Doze a treze dias após a inoculação das plantas a água contida na bandeja de isopor foi eliminada, assim como o plástico presente na parte posterior das caixas. Nestas mesmas datas, nos experimentos 5, 6, 7, 9, 10, 12, 13, 14, 15, 16, 17, 18 e 19 as plantas fonte foram aspergidas com água para a exsudação de bactérias contidas nas lesões já presentes (Tabela 1). Nos demais experimentos as plantas fonte permaneceram secas. A partir deste momento a umidade relativa do ar, no interior das caixas, variou de 80 a $85 \%$.

Também doze a treze dias após a inoculação, quarenta plantas sadias e apresentando brotações novas (plantas teste) foram colocadas nas caixas ao lado das plantas fonte para atração dos adultos do minador emergidos destas. Plantas fonte e teste permaneceram na mesma caixa durante todo o período de avaliação do experimento. Os experimentos de números 4 a 19 tiveram as plantas teste aspergidas com água antes da introdução nas caixas, para formação de água livre sobre as folhas. Nos experimentos de números 4,5 e 7 a 16 foram utilizadas agulhas para provocar ferimentos nas brotações novas das plantas teste. 


\subsubsection{Propagação do cancro cítrico por adultos da larva minadora com acesso a plantas doentes e sadias}

Neste tipo de experimento objetivou-se verificar a propagação da bactéria por adultos do minador que tiveram acesso a plantas doentes e, posteriormente, acesso a plantas sadias. Foram instalados dezoito experimentos conduzidos sequencialmente, tendo sido numerados de 20 a 37. Para cada experimento foram utilizadas quarenta plantas de limão cravo (plantas fonte) inoculadas com Xac. As quatro primeiras folhas de cada planta foram feridas com agulhas e em seguida imersas na suspensão bacteriana.

As plantas foram mantidas no interior de caixas de poliestireno e alumínio, com as mesmas características descritas anteriormente, mas adaptadas com um dispositivo (manga de tecido voil na parte frontal, em uma abertura de vinte centímetros de diâmetro) para colocação das plantas teste sem a fuga de insetos do interior das caixas. Após a inoculação, as plantas foram mantidas em câmara úmida por quatorze a dezesseis dias. Após este período, as plantas fonte foram aspergidas para formação de um filme de água sobre as folhas. Nos experimentos de números 22 e 23, quarenta plantas sadias (plantas teste) e com brotações novas foram colocadas no interior das caixas ao lado das plantas fonte, e em seguida foi realizada a liberação de quarenta adultos de $P$. citrella dentro das caixas (Tabela 2 ). Nos demais experimentos, os adultos tiveram maior tempo de acesso às plantas fonte antes da introdução das plantas teste. Nos experimentos 24 e 25 esse tempo foi de quarenta minutos; nos experimentos 20, 21, 26, e 27 foi de duas horas e nos experimentos de números 28 a 37 foi de 24 horas.

Somente nos experimentos de números 20,23 e 34 as plantas teste não foram aspergidas com água antes da introdução nas caixas. Nos experimentos número 20 e 34 a 37 não foram provocados ferimentos com agulhas nas brotações das plantas. Plantas fonte e teste permaneceram nas mesmas caixas, lado a lado, até o final das avaliações. 

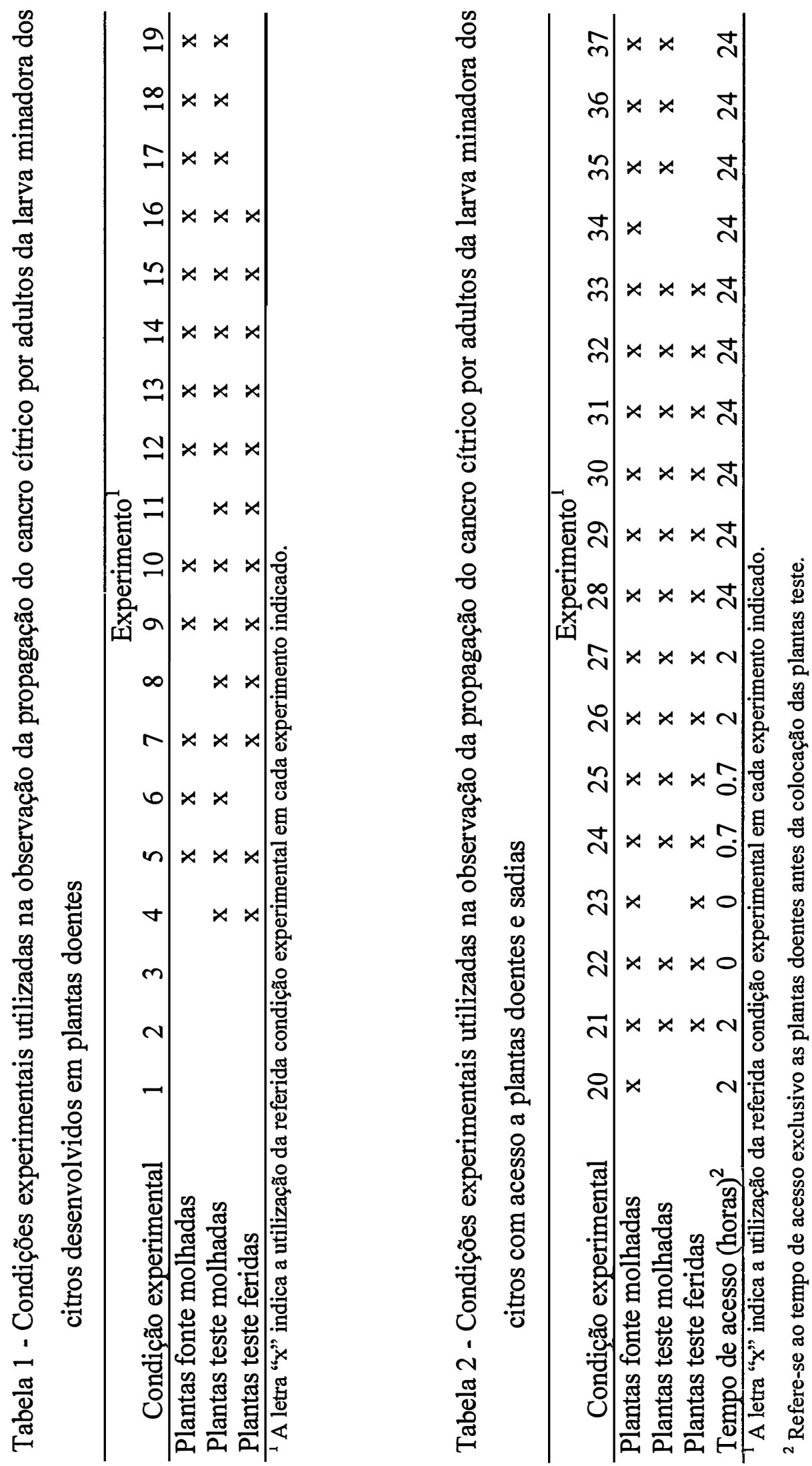


\subsubsection{Transporte e deposição de Xanthomonas axonopodis pv. citri por adultos da larva minadora}

Para a verificação do transporte/deposição da bactéria foram conduzidos três experimentos, numerados de 38 a 40 (Tabela 3). Em cada experimento oitenta adultos foram liberados em caixas contendo quarenta plantas fonte e quarenta plantas teste. Todas as plantas foram molhadas antes da introdução nas caixas. As plantas fonte foram obtidas como descrito anteriormente. Os experimentos foram iniciados após quinze dias da inoculação das plantas fonte. Os adultos do minador permaneceram com acesso às plantas inoculadas por vinte e quatro horas. As plantas teste não foram feridas mecanicamente. Dois a três dias após a liberação dos insetos, foram coletados quarenta adultos em cada experimento, colocados em tubos de vidro com $2 \mathrm{~mL}$ de tampão fosfato e deixados por doze horas, aproximadamente, a temperatura ambiente. Cada adulto foi colocado em um tubo de vidro. Após, $0,1 \mathrm{~mL}$ da suspensão foi plaqueada em meio de cultura SYS com rifampicina $\left(\mathrm{NH}_{4} \mathrm{H}_{2} \mathrm{PO}_{4} 0.5 \mathrm{~g}, \mathrm{~K}_{2} \mathrm{HPO}_{4} 0.5 \mathrm{~g}, \mathrm{MgSO}_{4} .7 \mathrm{H}_{2} \mathrm{O} 0.2 \mathrm{~g}\right.$, extrato de levedo $5.0 \mathrm{~g}$, sacarose $5.0 \mathrm{~g}$, ágar $15.0 \mathrm{~g}$, rifampicina $100 \mathrm{ppm} / \mathrm{litro}$ ) (três placas/tubo) a $28^{\circ} \mathrm{C}$ por 72 horas. No experimento $40,2-3$ folhas com ovos foram retiradas das plantas teste, colocadas em $2 \mathrm{~mL}$ de tampão fosfato e deixadas por doze horas, aproximadamente, a temperatura ambiente para observação da disseminação da bactéria por adultos após oviposição. Foi utilizado 1 tubo/planta. Posteriormente, aliquotas de $0,1 \mathrm{~mL}$ das suspensões resultantes foram plaqueadas em meio SYS com rifampicina (três placas/tubo) a $28^{\circ} \mathrm{C}$ por 72 horas.

\subsubsection{Avaliações}

A incidência da doença foi avaliada em todas as plantas teste aproximadamente quinze dias após a oviposição destas por adultos da larva minadora. Também foram avaliados o número de galerias e o número de folhas minadas em cada planta. Os dados foram comparados pelo número médio de galerias/planta e número médio de folhas minadas/planta, juntamente com os desvios padrões da média, e os números totais de 
galerias e folhas minadas. Nos experimentos realizados para observar o transporte/deposição da bactéria as placas com meio de cultura semi-seletivo foram observadas três dias após plaqueamento para verificação do crescimento de colônias características de Xac.

Tabela 3 - Condições experimentais utilizadas na observação do transporte e deposição de Xanthomonas axonopodis pv. citri por adultos da larva minadora dos citros com acesso a plantas doentes

\begin{tabular}{|c|c|c|c|}
\hline \multirow[b]{2}{*}{ Condições experimentais } & \multicolumn{3}{|c|}{ Experimento } \\
\hline & 38 & 39 & 40 \\
\hline Plantas fonte molhadas & $\mathbf{x}$ & $\mathbf{x}$ & $\mathrm{x}$ \\
\hline Plantas teste molhadas & $\mathbf{x}$ & $\mathbf{x}$ & $\mathbf{x}$ \\
\hline Plantas teste feridas & $\mathbf{x}$ & $\mathbf{x}$ & $\mathbf{x}$ \\
\hline Tempo de acesso (horas) ${ }^{1}$ & 24 & 24 & 24 \\
\hline Adultos coletados & $\mathbf{x}$ & $\mathbf{x}$ & $\mathbf{x}$ \\
\hline Folhas com ovos coletadas & & & $x$ \\
\hline
\end{tabular}

'Tefere-se ao tempo de acesso exclusivo as plantas doentes antes da colocação das plantas teste.

\subsection{Resultados}

Não foram observados sintomas de cancro cítrico em qualquer das plantas teste dos 37 experimentos realizados para verificar a propagação do cancro cítrico por adultos de $P$. citrella. Nos dezenove experimentos conduzidos para observação da propagação por adultos emergidos de plantas doentes ocorreram oviposições nas plantas teste, com exceção do experimento número 16 (Tabela 4). Os números de galerias e de folhas minadas encontradas nessas plantas variaram de 0 a 207 e 0 a 128, respectivamente, indicando que ocorreu o acasalamento entre os adultos emergidos de plantas doentes e as fêmeas ovipositaram em plantas sadias. A emergência dos adultos de $P$. citrella das plantas fonte ocorreu de quatorze a quinze dias após a inoculação das plantas. Nestas datas observou-se lesões de cancro cítrico presentes, na grande maioria, em galerias formadas pelas lagartas do inseto. Deste modo, a emergência dos adultos, e conseqüentemente a oviposição nas plantas sadias, ocorreram na presença da doença. 
Tabela 4 - Desenvolvimento da larva minadora dos citros em plantas teste de dezenove experimentos conduzidos para observação da propagação do cancro cítrico por adultos provenientes de plantas doentes

\begin{tabular}{ccccc}
\hline & \multicolumn{4}{c}{ Desenvolvimento da larva minadora dos citros } \\
Experimento & média \pm d.p. & $\begin{array}{c}\text { total } \\
\text { tón }\end{array}$ & número de folhas com galerias \\
média \pm d.p. & total \\
\hline 1 & $0,93 \pm 1,03$ & 37 & $0,93 \pm 1,03$ & 37 \\
2 & $1,83 \pm 1,28$ & 73 & $1,83 \pm 1,28$ & 73 \\
3 & $1,83 \pm 2,17$ & 73 & $1,55 \pm 1,76$ & 62 \\
4 & $3,45 \pm 2,98$ & 138 & $2,33 \pm 1,84$ & 93 \\
5 & $3,10 \pm 2,20$ & 124 & $1,98 \pm 1,31$ & 79 \\
6 & $3,43 \pm 2,01$ & 137 & $2,75 \pm 1,50$ & 110 \\
7 & $0,28 \pm 0,71$ & 11 & $0,28 \pm 0,71$ & 11 \\
8 & $1,88 \pm 2,04$ & 75 & $1,28 \pm 1,30$ & 51 \\
9 & $1,88 \pm 2,27$ & 75 & $1,23 \pm 1,29$ & 49 \\
10 & $1,08 \pm 1,39$ & 43 & $1,00 \pm 1,24$ & 40 \\
11 & $0,73 \pm 1,22$ & 29 & $0,73 \pm 1,22$ & 29 \\
12 & $0,80 \pm 1,27$ & 32 & $0,73 \pm 1,12$ & 29 \\
13 & $3,25 \pm 2,65$ & 130 & $2,13 \pm 1,62$ & 85 \\
14 & $2,10 \pm 2,02$ & 84 & $1,68 \pm 1,49$ & 67 \\
15 & $2,13 \pm 1,44$ & 85 & $2,00 \pm 1,36$ & 80 \\
16 & $0,00 \pm 0,00$ & 0 & $0,00 \pm 0,00$ & 0 \\
17 & $1,68 \pm 2,47$ & 67 & $0,80 \pm 1,03$ & 32 \\
18 & $5,18 \pm 3,32$ & 207 & $3,20 \pm 1,86$ & 128 \\
19 & $1,60 \pm 1,71$ & 64 & $1,43 \pm 1,48$ & 57 \\
\hline
\end{tabular}

'Corresponde ao número total de galerias em todas as quarenta plantas de cada experimento.

Nos experimentos com adultos em contato simultâneo com plantas doentes e sadias, somente no experimento número 21 não foi observada a presença de galerias nas folhas das plantas teste (Tabela 5). Apesar disso, foi observada a presença de um adulto morto em uma das folhas das plantas deste experimento, bem como a presença de vários adultos mortos na bandeja sob as plantas teste, comprovando que ocorreu a emergência de adultos das plantas doentes e o contato destes com as plantas teste. $\mathrm{O}$ número de galerias e de folhas minadas por planta variou de 0 a 276 e 0 a 210 , respectivamente. Nesses experimentos a oviposição pelos adultos nas plantas teste ocorreu de um a dois dias após a liberação desses nas caixas. 
Não foi verificada a presença de colônias típicas de Xac nos plaqueamentos realizados com tampão fosfato após a colocação de adultos que tiveram acesso a plantas doentes (experimentos números 38 a 40). Do mesmo modo, também não foi verificada a presença de Xac nos plaqueamentos realizados a partir da coleta de folhas com presença de ovos, resultante da oviposição de adultos que tiveram acesso a plantas sintomáticas.

Tabela 5 - Desenvolvimento da larva minadora dos citros em plantas teste de dezoito experimentos conduzidos para observação da propagação do cancro cítrico por adultos com livre acesso a plantas com e sem sintomas de cancro cítrico

\begin{tabular}{|c|c|c|c|c|}
\hline \multirow[b]{3}{*}{ Experimento } & \multicolumn{4}{|c|}{ Desenvolvimento da larva minadora dos citros } \\
\hline & \multicolumn{2}{|c|}{ Número de galerias } & \multicolumn{2}{|c|}{ Número de folhas com galerias } \\
\hline & média \pm d.p. & total $^{1}$ & média \pm d.p. & total \\
\hline 20 & $0.83 \pm 0.92$ & 33 & $0.83 \pm 0.92$ & 33 \\
\hline 21 & $0.00 \pm 0.00$ & 0 & $0.00 \pm 0.00$ & 0 \\
\hline 22 & $0.48 \pm 0.71$ & 19 & $0.48 \pm 0.71$ & 19 \\
\hline 23 & $0.55 \pm 1.09$ & 22 & $0.45 \pm 0.86$ & 18 \\
\hline 24 & $0.45 \pm 0.86$ & 18 & $0.45 \pm 0.86$ & 18 \\
\hline 25 & $0.33 \pm 0.75$ & 13 & $0.33 \pm 0.75$ & 13 \\
\hline 26 & $5.58 \pm 3.69$ & 223 & $3.65 \pm 2.09$ & 146 \\
\hline 27 & $0.58 \pm 1.07$ & 23 & $0.58 \pm 1.07$ & 23 \\
\hline 28 & $1.98 \pm 2.06$ & 79 & $1.75 \pm 1.94$ & 70 \\
\hline 29 & $3.45 \pm 2.77$ & 138 & $2.35 \pm 1.61$ & 94 \\
\hline 30 & $1.68 \pm 2.31$ & 67 & $1.43 \pm 1.87$ & 57 \\
\hline 31 & $2.60 \pm 2.04$ & 104 & $2.45 \pm 1.95$ & 98 \\
\hline 32 & $2.75 \pm 3.00$ & 110 & $1.93 \pm 1.80$ & 77 \\
\hline 33 & $1.20 \pm 2.70$ & 48 & $1.10 \pm 2.38$ & 44 \\
\hline 34 & $5.68 \pm 4.31$ & 227 & $3.40 \pm 2.32$ & 136 \\
\hline 35 & $4.18 \pm 2.64$ & 167 & $3.75 \pm 2.51$ & 150 \\
\hline 36 & $6.90 \pm 3.69$ & 276 & $5.25 \pm 2.73$ & 210 \\
\hline 37 & $1.70 \pm 2.20$ & 68 & $1.65 \pm 2.18$ & 66 \\
\hline
\end{tabular}

'Corresponde ao número total de galerias em todas as quarenta plantas de cada experimento.

\subsection{Discussão}

As variações observadas no número de galerias nas plantas teste (Tabelas $4 \mathrm{e}$ 5) podem ter ocorrido por diferenças na fecundidade e mortalidade dos adultos. Além disso, nos experimentos com adultos provenientes de plantas doentes, o número de ovos 
e larvas de primeiro ínstar nas plantas inoculadas foram diferentes entre os experimentos, resultado esse que pode ser observado pela diferença de galerias e de folhas com galerias.

Foram oferecidas diferentes condições para a ocorrência da propagação de Xac; como presença ou não de água livre sobre as folhas das plantas inoculadas e sadias, ferimentos nas brotações das plantas sadias e tempo de acesso às plantas doentes, em diferentes combinações (Tabelas 1 e 2). Considerando-se que a presença de água livre e ferimentos nas folhas representam as condições mais propícias para a disseminação de bactérias (Crosse et al., 1972; Daft \& Leben, 1972; Gottwald et al., 1992a), essa metodologia foi a mais utilizada nos experimentos, juntamente com um maior tempo de acesso dos adultos as plantas doentes, para os experimentos com acesso múltiplo as plantas doentes e sadias.

A presença de água livre nas folhas facilita a liberação do patógeno, o seu transporte e deposição, que são os eventos constituintes do processo de disseminação de um patógeno (Gottwald et al., 1997b; Koizumi et al., 1996; Zadoks \& Schein, 1979). A presença de ferimentos nas brotações, por sua vez, foi utilizada para facilitar a penetração da bactéria nas plantas, propiciando melhores condições para ocorrência de infeç̧ão (Egel et al., 1991; Graham et al., 1990), e conseqüentemente, a propagação da doença. Propagação, assim definido, seria o processo de disseminação de um patógeno seguido da infeç̧ão em uma planta hospedeira. Como o procodimento de avaliação nestes experimentos consistiu na procura por sintomas da doença nas plantas teste, ainda seria possível a ocorrência do transporte do patógeno (após liberação) ou sua disseminação (liberação, transporte e deposição), apesar da não ocorrência de infecção, o que caracterizou a não propagação por $P$. citrella. Deste modo, foram conduzidos experimentos específicos para verificar a disseminação (transporte + deposição) da bactéria pelo minador, os quais também apresentaram resultados negativos.

Os resultados dos experimentos relatados permitem concluir que a propagação do cancro cítrico por adultos de $P$. citrella não é um evento ocorrente na natureza e, por essa razão, não possui importância epidemiológica sob condições naturais de infecção por Xac. O aumento no número de casos da doença observados no Brasil (Gimenes- 
Fernandes et al., 2000) e em outros países (Gottwald et al., 1997b), após a introdução de P. citrella, não se deve à ação direta do inseto na disseminação do patógeno e sim à ação das fases imaturas nos sítios de infecção, conforme hipóteses discutidas na literatura (Gottwald et al., 1997b) e resultados obtidos em laboratório (Chagas et al., 2001).

As injúrias provocadas pelas fases imaturas constituem-se em portas de entrada para o patógeno. Por tratar-se de uma bactéria, a penetração no hospedeiro não ocorre de forma direta, mas por aberturas naturais (estômatos) e ferimentos (danos mecânicos e de insetos) (Crosse et al., 1972; Daft \& Leben, 1972). Assim, a ocorrência de lesões da larva minadora nas folhas cítricas constituem-se em novas e inúmeras portas de entrada para o patógeno, aberturas estas de menor magnitude antes da introdução do inseto. Em um segundo momento, estas injúrias permitem a coalescência das lesões de cancro cítrico. Maiores lesões da doença também representam maior concentração bacteriana (inóculo), aumentando as chances de disseminação na mesma planta ou para plantas vizinhas (Gottwald et al., 1989; Gottwald \& Graham, 1990).

Com base nos resultados aqui apresentados, a relação entre a larva minadora $\mathrm{e}$ o cancro cítrico envolve "infecção através de ferimentos de insetos sem a ocorrência de disseminação pelo agente que provoca o ferimento" (Rand \& Pierce, 1920). A não propagação do cancro cítrico pelo minador gera uma série de questões que podem ser exploradas. Neste sentido, é possível que os tecidos externos do inseto adulto sejam altamente hidrofóbicos, dificultando o transporte de bactérias suspensas em água livre durante o vôo, em quantidade suficiente para provocar infecção. Também é possível a presença de compostos químicos com efeito bacteriostático ou bactericida em partes externas do inseto, o que impediria o transporte de células bacterianas viáveis. 


\section{INJÚRIAS DA LARVA MINADORA DOS CITROS (Phyllocnistis citrella) INTENSIFICAM A INFECÇÃO POR CANCRO CÍTRICO (Xanthomonas axonopodis PV. citri)}

\section{Resumo}

Após a constatação da larva minadora dos citros no Estado de São Paulo foi observado um aumento no número de novas plantas infectadas pelo cancro cítrico. Apesar da interação existente entre o cancro cítrico e a larva minadora dos citros ser conhecida já há alguns anos, não há informações que permitam explicar claramente os aumentos observados na incidência/severidade do cancro cítrico quando de sua associação com as injúrias provocadas pelo inseto. Desta forma, no presente trabalho foram avaliados os efeitos de injúrias da larva minadora dos citros na infecção por cancro cítrico e a influência da larva minadora nos componentes monocíclicos da doença. Foram observadas maiores incidência de plantas doentes, área sobre a curva de progresso da doença $(A U D P C)$ e severidade e menor período de incubação quando a inoculação ocorreu em plantas infestadas pela larva minadora dos citros. Esses fatores explicam a associação encontrada entre a maior intensidade dos sintomas da doença e as injúrias do inseto e revelam, ainda que parcialmente, as conseqüências destas mudanças na disseminação da doença sob condições naturais de infecção.

\section{Summary}

Injuries of Citrus Leafminer (Phyllocnistis citrella) Intensifies the Infection by Citrus Canker (Xanthomonas axonopodis pv. citri) 
After the introduction of citrus leafininer in São Paulo state was observed an increase in the number of new diseased plants with citrus canker. The interaction between these two organisms is known, but there are no information about how exactly the leafminer damage promotes the increase in citrus canker incidence/severity. The objectives of the present work were to evaluate the effects of leafminer damage in citrus canker infection and its influence in the monocyclic components. Higher incidence of diseased plants, $A U D P C$ and severity and shorter incubation periods were observed in plants inoculated after insect infestation than in plants without insects. These factors explain the association found between the higher citrus canker intensity and the damage promoted by the insect and show, partially, the consequences of these changes in the disease spread under natural conditions of infection.

\subsection{Introdução}

As injúrias provocadas pela larva minadora dos citros [Phyllocnistis citrella (Stainton, 1856) (Lepidoptera, Gracillariidae)] aumentam a intensidade do cancro cítrico, isso tendo sido verificado em diferentes países (Chagas et al., 2001; Cook, 1988; Sinha et al., 1972; Sohi \& Sandhu, 1968; Venkateswarlu \& Ramapandu, 1992). Além dos danos diretos induzidos pelas injúrias deste inseto, na maioria dos casos em folhas de brotações novas, mas em altas infestações também presentes em ramos e frutos (Badawy, 1967; Clausen, 1931; Heppner, 1993; Prates et al., 1996), a associação direta com o cancro cítrico também tem sido relatada na literatura (Chagas et al., 2001; Gottwald et al., 1997b). Após a primeira constatação da larva minadora dos citros no Estado de São Paulo (Prates et al., 1996), foi observado um aumento dramático no número de novas plantas infectadas pela doença, o que provocou a mudança na metodologia de erradicação do cancro cítrico em setembro de 1999 (Chagas et al., 2001; Gimenes-Fernandes et al., 2000; São Paulo, 1999).

A penetração de bactérias fitopatogênicas em seus hospedeiros ocorre por aberturas naturais, geralmente estômatos, ou ferimentos (Crosse et al., 1972; Daft \& Leben, 1972). As injúrias induzidas pela larva minadora em folhas cítricas constituem-se 
em novas e inúmeras aberturas para a entrada do patógeno no hospedeiro. Após estabelecido o processo de infecção, os sintomas induzidos coalescem e formam largas áreas necróticas, possivelmente também em razão dos ferimentos provocados pelo inseto. Largas áreas do hospedeiro ocupadas por lesões servem como fonte de inóculo mais efetiva, em razão do maior número de células bacterianas presentes (Gottwald et al., 1988; Gottwald et al., 1989; Gottwald \& Graham, 1990).

Amostragens realizadas em áreas insfestadas no Yemen revelaram a ocorrência de folhas infectadas por cancro cítrico em associação com as injúrias do inseto (Cook, 1988). Na maioria das vezes as lesões da doença coincidiam com as galerias provocadas pela larva minadora e em menor freqüência, lesões eram encontradas isoladas das injúrias (Cook, 1988; Sohi \& Sandhu, 1968; Venkateswarlu \& Ramapandu, 1992). O inseto não é vetor da bactéria e a disseminação da doença pela ação dos insetos adultos nunca foi provada. Embora teoricamente possível, a disseminação da bactéria pelos insetos não possui importância epidemiológica sob condições naturais de infecção. Apesar da interação existente entre estes dois organismos ser conhecida já há alguns anos (Chagas et al., 2001; Cook, 1988; Gottwald et al., 1997b; Sohi \& Sandhu, 1968; Venkateswarlu \& Ramapandu, 1992), não há informações que permitam explicar claramente os aumentos observados na incidência/severidade do cancro cítrico quando de sua associação com o inseto (Chagas et al., 2001; Graham et al., 1996; Graham et al., 2004). Em consideração a esses fatos, os objetivos do presente trabalho foram (i) avaliar os efeitos de injúrias provocadas por diferentes ínstares da larva minadora dos citros na infecção por cancro cítrico e (ii) elucidar a influência da larva minadora nos componentes monocíclicos da doença.

\subsection{Material e métodos}

5.2.1 Efeito dos instares da larva minadora dos citros na infecção por Xanthomonas axonopodis pv. citri 
Plantas de limão cravo [Citrus limonia, (L.) Osbeck] com 20-25 centímetros de altura foram cultivadas em tubos plásticos (20 x 2,7 centímetros) contendo vermiculita e substrato orgânico (1:1) em casa-de-vegetação. Após quinze a vinte dias de podadas, as plantas foram colocadas por dois dias à disposição de adultos da larva minadora dos citros para oviposição em condições de laboratório a $25 \pm 1^{\circ} \mathrm{C}, 70 \pm 10 \%$ de umidade relativa e quatorze horas de fotofase (Chagas \& Parra, 2000). Após a oviposição, as plantas foram transferidas para incubadoras com temperaturas entre $18^{\circ} \mathrm{C}$ e $32^{\circ} \mathrm{C}$ para obtenção simultânea de folhas infestadas com as diferentes fases do inseto (Chagas, 1999). Dez plantas com cada uma das fases da larva minadora (ovos, larvas de primeiro, segundo, terceiro e quarto ínstares e pupa) foram inoculadas por aspersão de uma suspensão de Xanthomonas axonopodis pv. citri (Xac) contendo aproximadamente $10^{6}$ unidades formadoras de colônia por mililitro (UFC/mL). Para fins de comparação também foram inoculadas dez plantas com ferimentos mecânicos, provocados por agulha imediatamente antes da inoculação, e outras dez plantas não feridas, totalizando oito tratamentos em delineamento inteiramente casualizado e dez repetições. As plantas feridas mecanicamente continham entre três e sete folhas com quatro a dez furos cada. Todas as plantas foram aspergidas até o escorrimento da suspensão bacteriana e foram mantidas em câmara úmida por 96 horas após inoculação. Após a retirada da câmara úmida, todas as plantas foram mantidas em caixas de poliestireno (comprimento $\mathrm{x}$ largura $\times$ altura $=60 \times 40 \times 50$ centímetros) em condições de laboratório com temperatura a $28 \pm 2^{\circ} \mathrm{C}, 90 \pm 10 \%$ de umidade relativa e quatorze horas de fotofase. $\mathrm{O}$ experimento foi repetido uma vez.

\subsubsection{Comparação da idade de injúrias na infeç̧ão por Xanthomonas axonopodis pv. citri}

As mesmas condições experimentais descritas anteriormente foram utilizadas nesta segunda série de experimentos. Numa primeira etapa, plantas ovipositadas por adultos da larva minadora foram inoculadas sucessivamente, numa série iniciada no dia previsto da eclosão e finalizada quatro dias após o dia previsto da eclosão das larvas 
(DEL). Cada tratamento correspondeu à inoculação das plantas 1, 2, 3 e 4 dias após a eclosão ou simultaneamente a ela. Para comparação, cinco outros tratamentos foram utilizados, formados por plantas feridas mecanicamente por agulhas no mesmo dia da eclosão nos demais tratamentos, e da mesma forma. O total de tratamentos foi dez, testados em delineamento inteiramente casualizado e formados por dez repetições (plantas). $\mathrm{O}$ experimento foi repetido uma vez.

Em razão do desenvolvimento larval da minadora dos citros se estender, nas condições experimentais utilizadas, por aproximadamente oito a dez dias, um segundo experimento foi instalado, tendo-se inoculado plantas até doze DEL. O total de tratamentos testados foi dezenove, treze deles formados por plantas com injúrias provocadas pela larva minadora e inoculadas de zero a doze DEL, e outros seis formados por plantas feridas mecanicamente, inoculadas de zero a cinco dias após a realização dos ferimentos. $\mathrm{O}$ experimento foi repetido uma vez.

\subsubsection{Avaliações e análise dos dados}

A partir do quarto dia da inoculação todas as plantas foram avaliadas diariamente quanto à presença de sintomas de cancro cítrico. Os tratamentos foram comparados entre si quanto à incidência de plantas doentes, período de incubação, área abaixo da curva de progresso da incidência $(A U D P C)$ e severidade. O período de incubação foi considerado como o número de dias após inoculação para o aparecimento de ao menos uma lesão de cancro cítrico, visível a olho nu, por planta. Cada planta foi considerada uma repetição e os dados apresentados referem-se à média do número de dias/tratamento.

A $A U D P C$ foi calculada pela integração trapezoidal da incidência da doença no tempo, considerando todo o período avaliado, da seguinte forma:

$$
A U D P C=\sum_{i=1}^{n-1}\left(\frac{X_{i}+X_{i+1}}{2}\right)\left(t_{i+1}-t_{i}\right),
$$

sendo $X$ a incidência da doença (porcentagem de plantas doentes), $n$ o número de avaliações e $\left(t_{i+1}-t_{i}\right)$ o intervalo de tempo (dias) entre duas avaliações consecutivas 
(Campbell \& Madden, 1990). Nos cálculos foram considerados os dados de incidência coletados até os onze dias após a inoculação, na primeira série de experimentos (efeito dos ínstares da larva minadora), e até os vinte dias na segunda série (comparação da idade de injúrias).

Após quinze dias da inoculação da primeira série de experimentos foram coletadas dez folhas sintomáticas de cada tratamento, aleatoriamente, para avaliação da severidade da doença. Cada folha foi digitalizada em scanner e a severidade determinada pelo programa Quant (Vale et al., 2001). Os tratamentos foram comparados por análise de variância (teste F) para identificação de diferenças significativas nas variáveis período de incubação e severidade, e as respectivas médias comparadas pelo teste de Tukey $(p=0,05)$. Os dados obtidos nos dois experimentos foram analisados conjuntamente. As análises estatísticas foram processadas no programa Statistica 6.0.

$\mathrm{Na}$ segunda série de experimentos a severidade do cancro cítrico foi avaliada em folhas coletadas vinte dias após a inoculação das plantas. Os dados médios do período de incubação e severidade dos dois experimentos com plantas inoculadas até doze DEL foram analisados conjuntamente por análise de variância e teste de Tukey (Statistica 6.0).

\subsection{Resultados}

\subsubsection{Efeito dos ínstares da larva minadora dos citros na infecção por Xanthomonas axonopodis pv. citri}

A presença de ferimentos nas plantas exerceu grande efeito na ocorrência de infecção por cancro cítrico. Somente as plantas infestadas com larvas de primeiro e segundo ínstar apresentaram $100 \%$ de incidência, ocorrida aos doze e dez dias após a inoculação, respectivamente (Figura 1). A incidência máxima nas plantas feridas mecanicamente foi de $80 \%$, observada aos dez dias após inoculação. Na ausência de ferimentos apenas $10 \%$ das plantas mostraram sintomas da doença e as plantas 
inoculadas quando com ovos do inseto apresentaram no máximo $60 \%$ de incidência de plantas doentes, aos onze dias após a inoculação.

O período médio de incubação variou de 6,8 a 8,6 dias e apenas o tratamento formado por plantas infestadas com ovos diferiu significativamente dos demais tratamentos (Tabela 1). As plantas infestadas com larvas de terceiro ínstar foram as que apresentaram os sintomas no menor período de tempo. Em razão de apenas $10 \%$ das plantas inoculadas sem ferimentos terem apresentado sintomas, este tratamento não foi utilizado nas análises estatísticas para comparação do período de incubação. As diferenças observadas no período incubação foram similares as observadas na $A U D P C$. Os maiores valores foram observados nas plantas inoculadas quando infestadas com larvas de segundo e terceiro ínstares, seguidas pelas plantas com larvas de primeiro ínstar. Os menores valores ocorreram para as plantas infestadas com ovos e sem ferimentos.

A presença dos ferimentos da larva minadora também aumentou a severidade do cancro cítrico. Maior severidade foi observada nas plantas infestadas com larvas de terceiro e quarto ínstares. Plantas infestadas com pupa e larvas de segundo ínstar apresentaram severidades semelhantes. As menores severidades da doença ocorreram em plantas infestadas com larvas de primeiro ínstar, ovos e naquelas que receberam ferimentos mecânicos. Não foram detectadas diferenças significativas entre estes três últimos tratamentos. $\mathrm{O}$ tratamento formado pelas plantas inoculadas sem ferimentos foi excluído na análise dos dados de severidade.

\subsubsection{Comparação da idade de injúrias na infecção por Xanthomonas axonopodis pv. citri}

As maiores incidências de plantas doentes ocorreram nos tratamentos formados por plantas inoculadas até seis DEL ou no mesmo dia da realização dos ferimentos mecânicos. A evolução dos sintomas foi mais rápida nas plantas inoculadas simultaneamente ao ferimento mecânico e à eclosão dos ovos da larva minadora (Figura 2). Praticamente o dobro do tempo foi necessário para que as plantas inoculadas no 

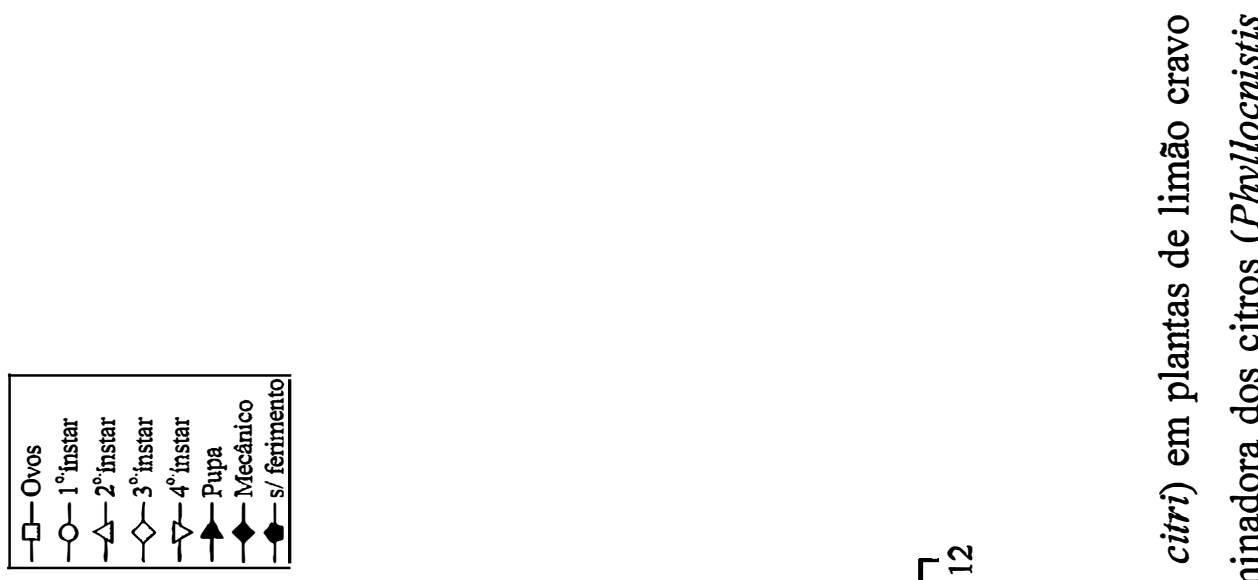

밍

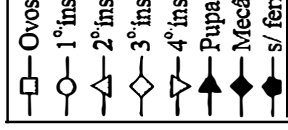

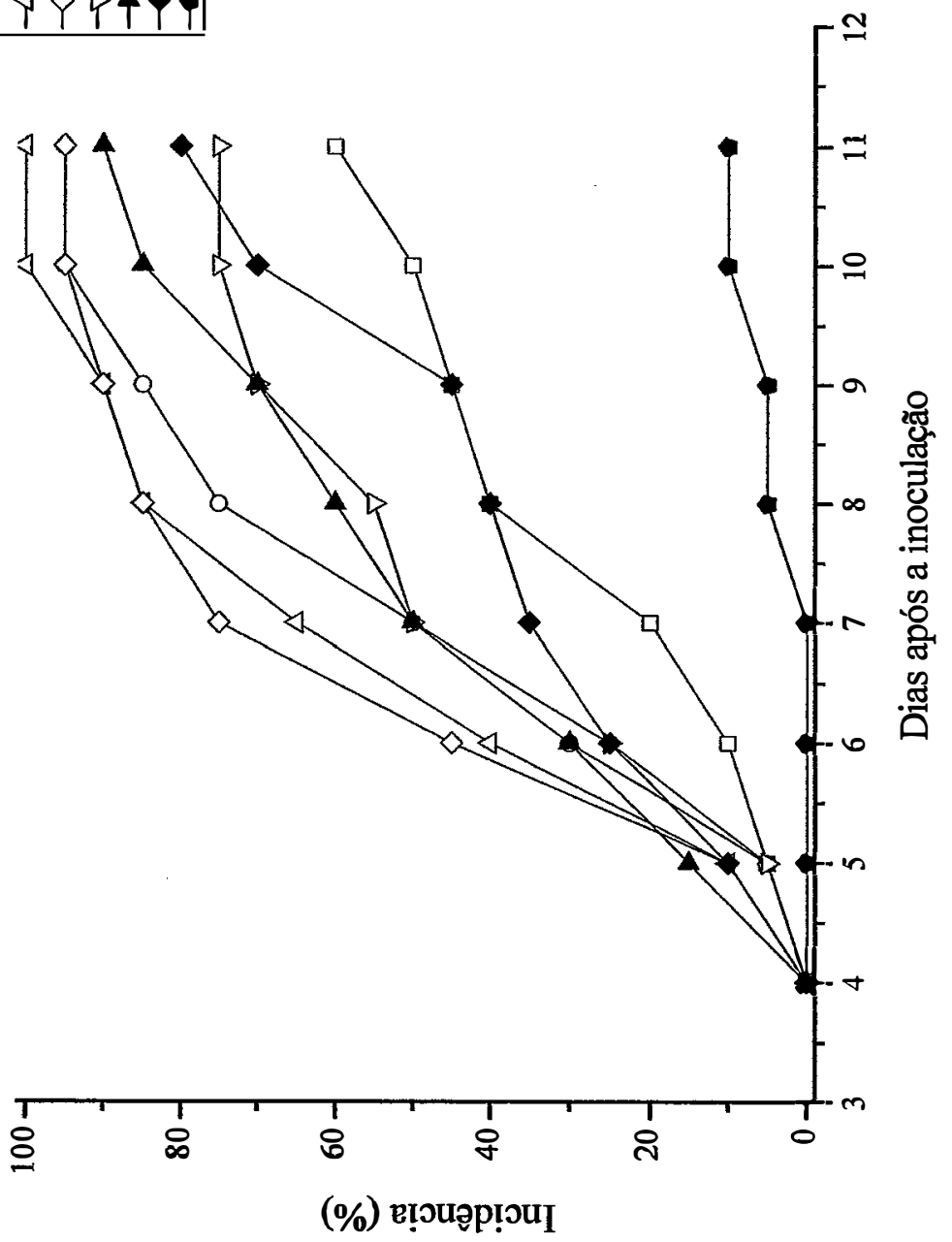




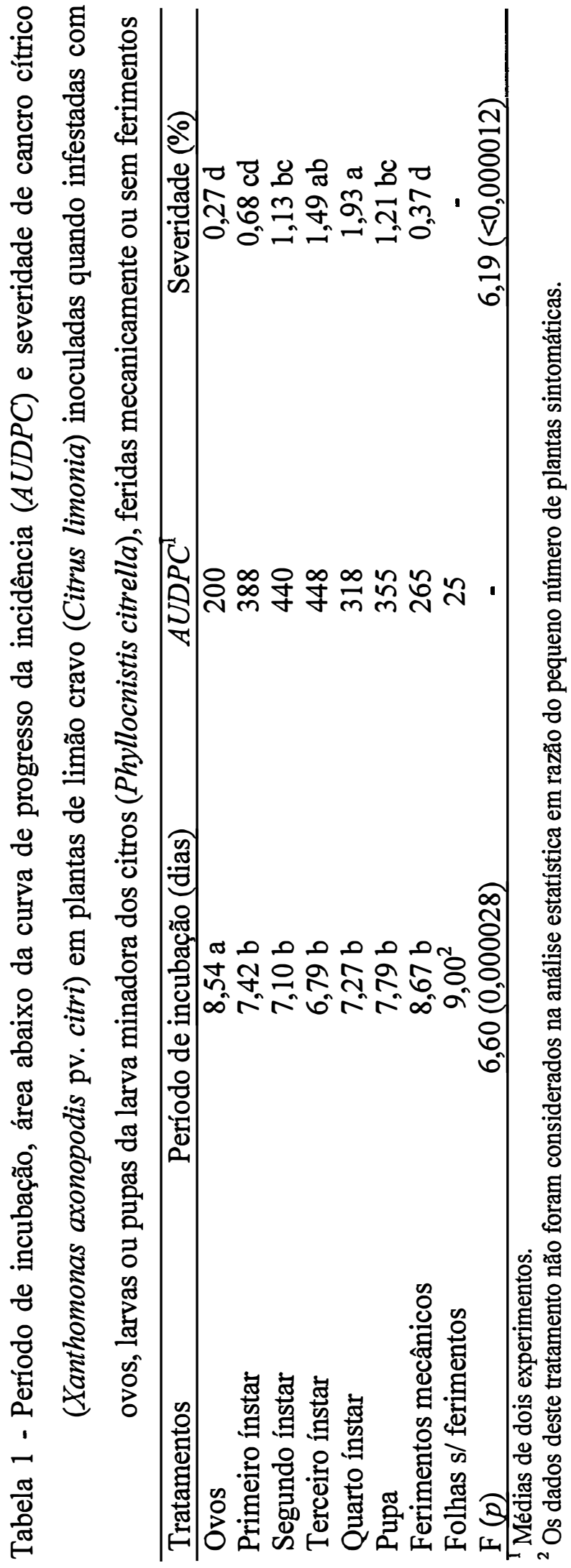


quarto DEL atingissem $100 \%$ de incidência. A incidência da doença nos tratamentos em que a inoculação da bactéria foi feita um dia após a realização dos ferimentos mecânicos foi de $80 \%$, atingida aos quatorze dias. A inoculação após dois ou três dias da realização dos ferimentos mecânicos resultou em incidências de 40 e 30\%, respectivamente, observadas a partir dos quinze dias após a inoculação, similar ao observado para as plantas infestadas com larva minadora e inoculadas aos doze dias. Plantas feridas mecanicamente quatro e cinco dias antes da inoculação com Xac não apresentaram sintomas da doença durante todo o período de experimentação, que estendeu-se até os trinta e um dias após a inoculação (dados não apresentados). As plantas feridas três dias antes da inoculação apresentaram sintomas em apenas um dos experimentos.

O período de incubação variou de 6,6 a 24,6 dias e os menores períodos foram observados nas plantas inoculadas no dia da eclosão ou da realização dos ferimentos mecânicos (Tabela 2). $\mathrm{O}$ atraso em um e dois dias na inoculação das plantas feridas mecanicamente resultou em períodos de incubação três e dez dias mais longos, respectivamente. $\mathrm{O}$ mesmo comportamento ocorreu para as inoculações realizadas em plantas infestadas com a larva minadora, mas com atrasos menos drásticos no período de incubação. Longos períodos de incubação, próximos ou superiores a vinte dias, ocorreram nas inoculações a partir do nono DEL. De maneira semelhante, foi observada uma queda gradativa nos valores de $A U D P C$ com o aumento no número de dias decorridos entre a eclosão das larvas, ou da realização dos ferimentos mecânicos, e a inoculação. A inoculação das plantas após nove e dez DEL resultou em valores de $A U D P C$ semelhantes à inoculação das plantas dois dias após feridas. Apesar das diferenças entre os valores de severidade da doença em folhas inoculadas quando infestadas pela larva minadora e as feridas mecanicamente, em termos absolutos, diferenças significativas ocorreram somente entre alguns dos tratamentos testados. Severidades médias superiores a $4 \%$ corresponderam à inoculação das plantas aos oito $\mathrm{e}$ nove DEL, enquanto severidades superiores a $2 \%$ foram observadas nas plantas inoculadas aos zero, um, dois e três DEL. A inoculação das plantas feridas mecanicamente nos mesmos períodos resultaram em severidades próximas ou inferiores a $1 \%$. 


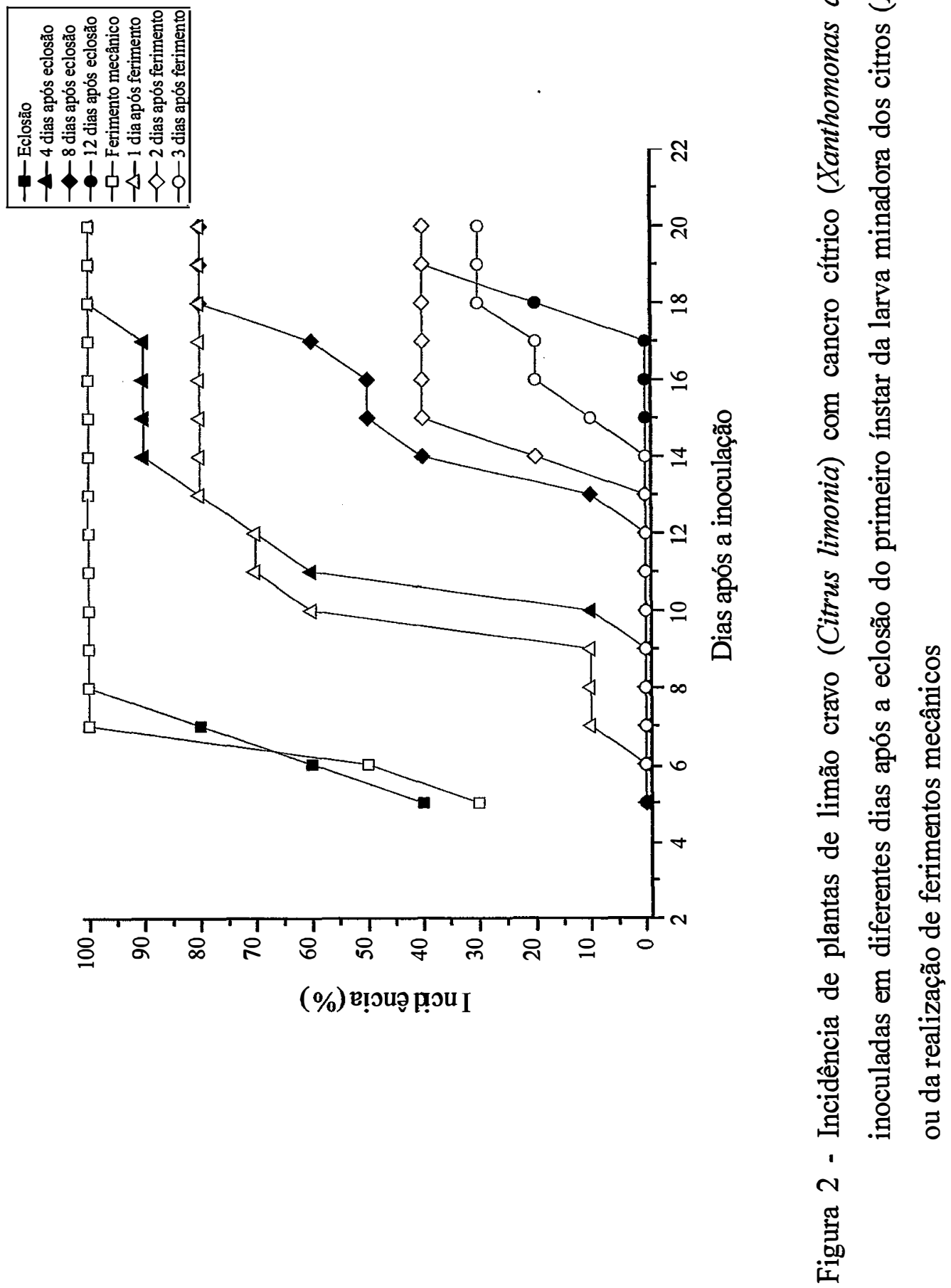




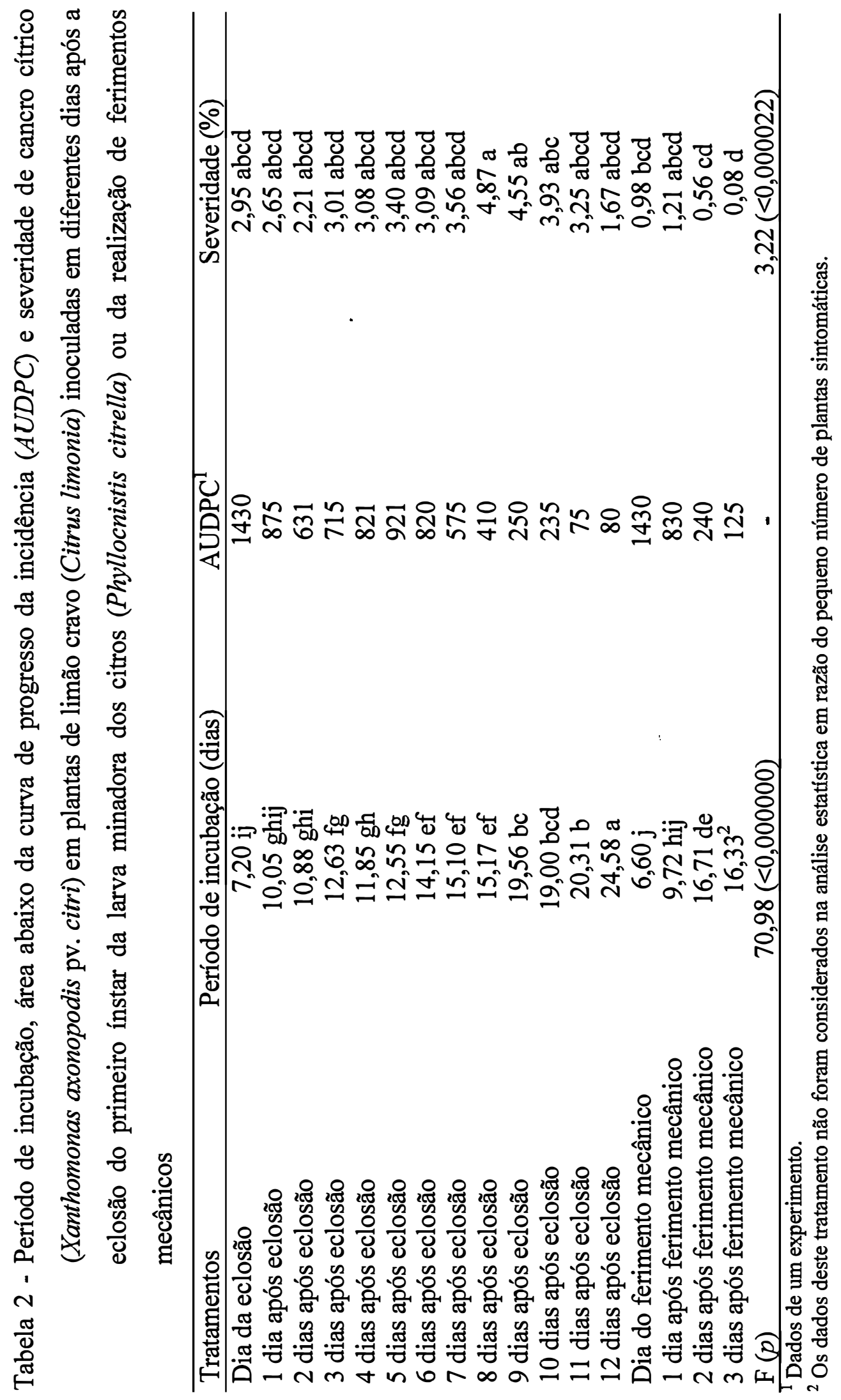




\subsection{Discussão}

A intensidade da doença foi maior com a presença das injúrias provocadas pela larva minadora dos citros. Os sintomas da doença apareceram mais rapidamente, a proporção de plantas doentes e a severidade foram maiores e os tecidos permaneceram suscetíveis por mais tempo. Esses fatores explicam a associação encontrada entre a intensidade dos sintomas da doença e as injúrias do inseto (Chagas et al., 2001; Cook, 1988; Sohi \& Sandhu, 1968; Venkateswarlu \& Ramapandu, 1992). A infecção bacteriana é mais severa quando há algum tipo de injúria em seus hospedeiros, e a extensão dessas injúrias pode ter importância epidemiológica (Pohronezny et al., 1992). A importância de ferimentos mecânicos na infecção por Xac foi demonstrada anteriormente sob condições experimentais (Vernière et al., 2003). Enquanto a inoculação de tecidos de diferentes idades, na presença de ferimentos, resultou em pequenas diferenças quanto à expressão dos sintomas, a incidência de tecidos doentes foi três a seis vezes menor na ausência destes.

Durante a inoculação das plantas nos experimentos aqui relatados foram simuladas condições naturais do processo de infecção por Xac. Todas as plantas foram inoculadas com uma suspensão bacteriana a $10^{6} \mathrm{UFC} / \mathrm{mL}$, considerada como o limiar de infecção em inoculações artificiais (Beattie \& Lindow, 1995). A inoculação por aspersão reproduziu os mecanismos mais comuns de disseminação do patógeno que dá-se por respingos de chuvas e de chuvas associadas com ventos (Gottwald et al., 1989). A ação de ventos que excedem oito $\mathrm{m} / \mathrm{s}$ induz ferimentos em folhas, ramos e frutos, que podem resultar em significativo aumento da doença (Gottwald et al., 1988). Os ferimentos mecânicos realizados nas plantas antes das inoculações simularam estes ferimentos existentes em folhas sob condições naturais de epidemia.

As maiores incidências de plantas doentes e os menores períodos de incubação ocorreram em plantas infestadas com as fases imaturas da larva minadora. Isto deve-se à extensão das respectivas injúrias. Os ferimentos mecânicos provocados com agulhas possuíam extensões muito inferiores que as induzidas pela larva minadora. Considerando que o mesmo número de células bacterianas entraram em contato com os 
tecidos foliares durante a inoculação, as modificações ocorridas no processo de infeç̧ão devem-se ao número de células bacterianas que entraram em contato com os tecidos danificados do mesófilo foliar. A concentração de células bacterianas pode alterar o período de incubação, e a expressão mais rápida dos sintomas é indurida por maiores concentrações (Beattie \& Lindow, 1995). Durante o processo de alimentação, a larva minadora danifica e expõe o mesófilo foliar, aumentando a probabilidade de contato do patógeno diretamente com o interior do hospedeiro. Apesar da extensão das injúrias estar diretamente relacionada com o desenvolvimento do inseto, sendo máxima na fase de pupa, a máxima probabilidade de contato existe quando as folhas encontram-se com os segundo e terceiro ínstares da larva minadora. Quando a larva encontra-se nos estádios de quarto ínstar ou pupa é comum as folhas encontraram-se enroladas, o que reduz a superfície exposta à deposição da bactéria. Uma segunda explicação é que as células bacterianas, na presença de ferimentos, entram diretamente em contato com o interior dos tecidos foliares, e a fase de pré-penetração, caracterizada pela multiplicação na superfície do hospedeiro é suprimida. Como resultado têm-se a penetração e infecção mais rapidamente, em comparação com tecidos intactos.

As maiores extensões das injúrias permitem não somente máximas incidências, como também observado por outros autores (Chagas et al., 2001), mas também que estas incidências máximas ocorram mais rápido no tempo. A combinação destes dois componentes está expressa nos valores da $A U D P C$, a qual considera muitas das características associadas a uma epidemia e revela uma medida quantitativa da expressão dos sintomas (Vernière et al., 2003). Em plantas inoculadas quando infestadas com ovos da larva minadora as incidências e as médias da $A U D P C$ foram maiores que em plantas sem injúrias. As plantas inoculadas com ovos não apresentavam injúrias, mas estas ocorreram um a dois dias após a inoculação, em razão da eclosão das larvas de primeiro ínstar (Chagas \& Parra, 2000). Desta maneira, as células bacterianas presentes na superfície foliar puderam entrar em contato diretamente com os tecidos danificados pelas larvas recém emergidas. A manutenção das plantas em câmara úmida por 96 horas após a inoculação permitiu a sobrevivência de muitas células bacterianas por dias após a inoculação. 
As severidades de cancro cítrico foram maiores nas plantas inoculadas quando apresentavam larvas nos terceiro e quarto ínstares. Nos experimentos para comparação da idade de ferimentos, os tratamentos com plantas infestadas pelo inseto não diferiram entre si estatisticamente, apesar dos maiores valores absolutos terem ocorrido nas plantas inoculadas oito e nove DEL. Estes resultados diferem dos obtidos quanto ao período de incubação, incidência de plantas e $A U D P C$, os quais mostraram infecções mais intensas para as plantas infestadas até terceiro ínstar. As avaliações de severidade foram realizadas aos quinze dias após a inoculação dos experimentos instalados para avaliação do efeito dos diferentes ínstares e aos vinte dias nos demais experimentos. Nestas datas as folhas sintomáticas das plantas inoculadas com larvas de quarto ínstar e pupa encontravam-se mais fortemente retorcidas e deformadas que as folhas dos demais tratamentos em razão dos estádios mais avançados de desenvolvimento do inseto. Conseqüentemente, a área foliar total estava grandemente reduzida, o que resultou em maiores severidades nestes tratamentos.

As diferenças observadas nos tratamentos correspondentes às idades dos ferimentos provocados pela larva minadora e mecânicos devem-se em parte ao desenvolvimento larval do inseto durar vários dias. As inoculações realizadas dias após a eclosão das larvas promoveram o contato entre patógeno e hospedeiro na presença de ferimentos. Nas condições experimentais avaliadas, a eclosão das larvas ocorre em média um a dois dias após a oviposição, a duração da fase larval é de quatro dias e a de pupa de oito dias, aproximadamente (Chagas \& Parra, 2000). Desta forma, as inoculações no dia zero corresponderam à fase de ovo, as realizadas no dia dois à fase de segundo ínstar, e as inoculações realizadas aos quatro/cinco DEL corresponderam ao início da fase de pupa. Durante o desenvolvimento das fases imaturas do inseto as injúrias nos tecidos foliares aumentam continuamente até o final do quarto ínstar. Apesar disso, as inoculações em plantas até doze DEL resultaram em sintomas da doença, indicando a ocorrência de infecção aproximadamente seis dias após atingida a fase de pupa, quando a realização de novos ferimentos não mais ocorre. Como sugerido por Goto (1990), ferimentos provocados de forma drástica, como ferimentos mecânicos, cicatrizam mais rapidamente, em alguns dias, enquanto ferimentos provocados pela 
larva minadora cicatrizam mais lentamente, tornando os tecidos foliares suscetíveis à infecção por períodos mais longos.

$\mathrm{O}$ aumento observado na incidência de plantas com cancro cítrico no Brasil, e também em outros países, ocorreu em função das mudanças no processo de infecção por Xac (Gimenes-Fernandes et al., 2000; Gottwald et al., 2001; Graham et al., 2004). As injúrias provocadas pelo inseto representam novos e inúmeros pontos de entrada do patógeno, e, num segundo momento, permitem a coalescência das lesões (Graham et al., 1996; Graham et al., 2004; Gottwald et al., 1997b). Maiores áreas do hospedeiro ocupadas pelos sintomas da doença podem representar maiores fontes de inóculo (células bacterianas) passíveis de disseminação (Gottwald et al., 1988; Gottwald et al., 1989; Gottwald \& Graham, 1990). Considerando as hipóteses estabelecidas por estes autores e os dados experimentais aqui apresentados, pode-se concluir que: a) as injúrias provocadas pela larva minadora aumentam a incidência da doença com reflexo na $A U D P C$; b) as plantas infestadas com a larva minadora e infectadas por Xac apresentam sintomas da doença mais rapidamente, em comparação com infecções ocorridas na ausência de ferimentos. A redução no período de incubação, que possui o mesmo significado que o período de latência neste patossistema, provoca um maior número de ciclos da doença, com conseqüências epidemiológicos relevantes; c) os tecidos doentes apresentam maiores severidades, e, conseqüentemente, maiores populações bacterianas encontram-se passíveis de disseminação na mesma planta e plantas vizinhas; d) as injúrias provocadas pelo inseto demoram a cicatrizar e permitem infecções por períodos mais longos, de vários dias, enquanto ferimentos mecânicos cicatrizam em aproximadamente três dias.

A mudança provocada pela introdução da larva minadora dos citros no processo de infecção por Xac teve importantes conseqüências nas campanhas de erradicação do cancro cítrico no Brasil e na Flórida (Chagas et al., 2001; GimenesFernandes et al., 2000; Gottwald et al., 1997b; Gottwald et al., 2001; Gottwald et al., 2002a; Gottwald et al., 2002b). A presença da larva minadora dos citros alterou o padrão espacial do cancro cítrico em São Paulo (Bergamin Filho et al., 2000). Antes da sua presença o cancro cítrico apresentava padrões de distribuição mais agregados. Após, 
foram observados padrões menos agregados e a presença mais comum de focos satélites, mais distantes dos focos iniciais da doença no talhão. Os resultados experimentais aqui apresentados referem-se às mudanças ocorridas nos componentes monocíclicos da doença, mas as conseqüências destas mudanças nos padrões temporal e espacial da doença ainda necessitam de investigação (Bergamin Filho et al., 2000). 


\section{DINÂMICA ESPACIAL DO CANCRO CÍTRICO EM TALHÕES DE LARANJEIRA ‘NATAL’ SOB CONDIÇÕES NATURAIS DE INFECÇÃO}

\section{Resumo}

Em razão do seu status de doença quarentenária, a qual exige a erradicação das plantas doentes e das suspeitas de infecção, nenhum acompanhamento do progresso espaçotemporal do cancro círico pôde ser realizado até hoje no Brasil. Objetivando o estudo da dinâmica espacial do cancro cítrico sob condições naturais de infecção, talhões de laranjeira doce 'Natal', infectados com cancro cítrico, foram mapeados quanto à localização das plantas doentes, antes que a erradicação fosse efetuada, em uma área naturalmente contaminada. Também foram quantificadas as incidências de plantas e de folhas sintomáticas/planta e os dados usados nas análises de seqüências ordinárias, dinâmica e estrutura de focos, determinação das distâncias entre plantas doentes, gradientes de doença e na confecção de mapas de linhas isópatas. As plantas doentes também foram quantificadas quanto aos fluxos vegetativos sintomáticos, de modo a avaliar-se, parcialmente, o progresso da doença no tempo e no espaço. A incidência de plantas doentes variou de 0,17 a 70,76\% nos talhões estudados, atingidas entre doze e quatorze meses do início do plantio. Talhões com maiores incidências de plantas doentes apresentaram plantas com maiores incidências de folhas sintomáticas. Maior agregação de plantas doentes ocorreu ao longo das linhas do que entre linhas de plantas. $O$ crescimento da doença caracterizou-se tanto pelo aumento do número de focos quanto pelos aumentos nos números de focos unitários e de plantas/foco. Melhores ajustes foram obtidos com o modelo potência inversa na análise dos gradientes de doença. $\mathrm{O}$ incremento da doença, associado ao crescimento do hospedeiro, resultou em gradientes 
de doença mais suaves e menores coeficientes angulares $(b)$. As distâncias mínima e máxima observadas entre plantas doentes foram de 3,50 e 177,16 metros, e entre 11,90 e $100,00 \%$ das distâncias entre plantas doentes, cujos sintomas apareceram em fluxos vegetativos distintos, eram iguais ou inferiores a trinta metros.

\section{Summary}

\section{Spatial Dynamic of Citrus Canker in Blocks of Sweet Orange 'Natal' Under Natural Infection Conditions}

In reason of the status of quarentenary disease, that provokes the eradication of infected and suspected plants, there is no study of the spatiotemporal progress of citrus canker in brasilizian conditions. With the objective of study the spatial dynamic of citrus canker under natural conditions of infection, blocks with infected sweet orange 'Natal' plants were evaluated and the infected plants localized. The incidence of diseased plants and symptomatic leaves/plant were measured and these datas used in analysis of ordinary runs, disease foci, to determine the distances between diseased plants, gradients of disease and isopath contour maps. The differents vegetative flushes presented in diseased plants were evaluated to stimate the time of infection and, partially, study the citrus canker progress in time and space. The incidences of diseased plants were between 0.17 and $70.76 \%$ in the evaluated blocks, and these incidences occurred twelve and fourteen months after sowing. Blocks with higher incidences of diseased plants presented higher incidences of symptomatic leaves per plant. Higher aggregation of diseased plants occurred in the rows than between rows. The increment of disease in the blocks was resulted of the increases in the number of foci, number of unitary foci and number of plants/foci. The power law model better described the disease gradients. The increase of disease, associated with the host growth, resulted in steeper disease gradients and lower slopes $(b)$. The minimum and maximum distances determined between diseased plants were 3.50 and 177.16 meters, and between 11.90 and $100.00 \%$ of the 
distances between diseased plants in different vegetative flushes were equal or lower of tirty meters.

\subsection{Introdução}

A primeira ocorrência do cancro cítrico no Brasil foi em 1957, no município de Presidente Prudente, SP (Bitancourt, 1957). Medidas de exclusão e erradicação foram adotadas neste mesmo ano e foi iniciada uma campanha de erradicação do cancro cítrico, que permanece ativa até os dias atuais (Gimenes-Fernandes et al., 2000). No Estado de São Paulo a legislação adotada desde setembro de 1999 determina a eliminação de todas as plantas do talhão, quando a incidência de cancro cítrico for superior a $0,5 \%$ (São Paulo, 1999). Para incidências iguais ou menores que $0,5 \%$, as plantas doentes e as demais contidas num raio de trinta metros são eliminadas.

A mudança na metodologia de erradicação em São Paulo foi provocada pelo incremento da incidência de cancro cítrico após a introdução, em 1996, da larva minadora dos citros (Phyllocnistis citrella Stainton - Lepdoptera: Gracillariidae: Phyllocnistinae) (Prates et al., 1996). A presença da larva minadora alterou o padrão espacial da doença em São Paulo (Bergamin Filho et al., 2000). Antes de seu ingresso, plantas sintomáticas apresentavam-se agregadas no campo. Após a introdução da praga, as plantas doentes formaram padrões menos agregados, com a presença mais comum de focos satélites, distantes dos focos iniciais. As formas imaturas desta praga, em razão do seu hábito alimentar, provocam galerias na epiderme de tecidos jovens, principalmente nas folhas (Chagas \& Parra, 2000; Heppner, 1993), expondo o mesófilo foliar e tornando a folha mais suscetível à infecção por Xac (Chagas et al., 2001; Gottwald et al., 1997b). Além disso, os ferimentos provocados pela larva minadora transformaram os aerossóis em mecanismos eficientes de disseminação da doença; aerossóis são formados principalmente durante a ocorrência simultânea de chuva e vento, situação comum em nossas condições durante a emissão de brotações pelas plantas cítricas.

O trabalho de Bergamin Filho et al. (2000), que resultou na mudança da metodologia de erradicação em São Paulo, foi feito com mapas de talhões comerciais 
contaminados confeccionados após a detecção da doença por equipes de inspetores. Por tratar-se de doença quarentenária, a qual exige a erradicação de plantas doentes e das suspeitas de infecção, determinada por medida legal a ser executada após a constatação da doença, nenhum acompanhamento do progresso da doença no tempo pôde ser realizado até hoje no Brasil. Diante disso, o presente trabalho objetivou o estudo da dinâmica espacial do cancro cítrico em talhões de laranjeira 'Natal', sob condições naturais de infecção da bactéria e da larva minadora dos citros.

\subsection{Material e métodos}

\subsubsection{Parcelas experimentais e coleta de dados}

Em um curto espaço de tempo, anteriormente à erradicação, avaliou-se a incidência de cancro cítrico em todas as plantas de quatorze talhões de laranjeira 'Natal' enxertada em limoeiro 'Cravo' com três anos de idade. Os talhões, com 595 ou 1080 plantas cada, foram naturalmente infectados por Xac e estavam localizados na mesma propriedade. Todos os talhões foram mapeados e as plantas doentes identificadas. A incidência da doença foi expressa em número de plantas doentes por talhão $\mathrm{e}$ porcentagem de folhas sintomáticas por planta. A incidência de folhas sintomáticas por

planta foi estimada por meio de uma escala com os seguintes níveis: 1 - até 5 folhas; 2 de 6 a 10 folhas; 3 - de 11 a 20 folhas; 4 - de 21 a 50 folhas; 5 - >50 folhas.

Todas as plantas de doze, dos quatorze talhões com plantas sintomáticas (talhões 2, 4, 5, 6, 7, 8, 15, 20, 22, 24, 25, e 26), e em outras 133 plantas do talhão 1 e 93 do talhão 3 , foram identificadas quanto aos fluxos vegetativos sintomáticos. Essa identificação serviu para estimar a época em que a infecção ocorreu: quanto mais antigo for o fluxo vegetativo sintomático, mais antiga é a infecção. Dados meteorológicos diários, referentes à precipitação pluviométrica e temperaturas mínima e máxima da região de ocorrência da epidemia foram utilizados para estimar as prováveis épocas de emissão dos fluxos vegetativos e disseminação/infecção das plantas por Xac. 
A maioria das plantas continha quatro fluxos vegetativos na época de avaliação. Uma pequena parte das plantas (menos que dez porcento) havia emitido um quinto fluxo vegetativo, que encontrava-se ainda com as folhas em expansão. Em razão deste quinto fluxo vegetativo ter sido emitido poucas semanas após a emissão do quarto fluxo e das folhas doentes encontradas neste último fluxo estarem com sintomas iniciais, estas plantas foram consideradas com apenas quatro fluxos vegetativos, e os dois últimos fluxos (quarto e quinto) foram considerados como sendo um mesmo fluxo (quarto). Este procedimento uniformizou os dados obtidos e facilitou a comparação dos talhões, além de evitar que plantas infectadas no quinto fluxo vegetativo, ainda assintomáticas, fossem consideradas como sadias e o incremento da doença subestimado.

\subsubsection{Análise de seqüências ordinárias}

Para todos os talhões nos quais avaliou-se os fluxos vegetativos quanto à presença de folhas sintomáticas foi calculado o índice $\mathrm{Z}$ para determinação da agregação de plantas doentes nas linhas de plantas e entre linhas de plantas (Madden et al., 1982). Quanto maior a agregação, mais negativo é o valor de $Z$, e o valor calculado foi

comparado com $Z=1,64$, que é o limite a $p=0,05$ para determinação da agregação de plantas. As plantas são consideradas agregadas quando o valor de $\mathrm{Z}$ calculado for igual ou inferior a 1,64 .

\subsubsection{Dinâmica e estrutura de focos}

Para todos os talhões foram calculados o número de focos (NF), o número de focos unitários (NFU) e o número médio de plantas por foco (NMPF) (Laranjeira et al., 1998; Nelson, 1996). Somente as plantas imediatamente adjacentes entre si nas linhas ou entre linhas (direções horizontal, vertical ou diagonal) foram consideradas como pertencentes ao mesmo foco. O cálculo dessas variáveis foi realizado para cada fluxo vegetativo, ou seja, calculou-se NF, NFU e NMPF considerando a incidência de doença nos primeiro, segundo, terceiro e quarto fluxos vegetativos. Essas variáveis também 
foram relacionadas com a incidência de plantas/talhão considerando todo o conjunto de dados.

\subsubsection{Distâncias entre plantas doentes}

As distâncias entre plantas doentes em cada um dos talhões avaliados foram calculadas considerando: a) todas as combinações possíveis de distâncias entre plantas que apresentavam sintomas em um mesmo fluxo vegetativo; b) as distâncias entre plantas doentes de um fluxo vegetativo (consideradas como plantas foco) e as demais plantas doentes do fluxo vegetativo imediatamente posterior. Os resultados obtidos foram apresentados graficamente pela freqüência de plantas em cada classe de distância de 3,5 metros, que corresponde à distância mínima entre plantas nos talhões avaliados (Gottwald et al., 2002b). Também foram calculadas as porcentagens de distâncias entre plantas doentes iguais ou inferiores a trinta metros. Esse cálculo considerou as distâncias de plantas doentes em fluxos vegetativos distintos, ou seja, plantas com sintomas no primeiro fluxo foram consideradas foco das plantas com sintomas no segundo fluxo vegetativo, e assim sucessivamente. Também foram estimadas as distâncias (raios) que compreendiam cinquenta, setenta, noventa e $99 \%$ das distâncias entre plantas doentes.

\subsubsection{Análise dos gradientes de doença}

Os modelos exponencial negativo $\left(y=a \exp ^{(-b s)}\right)$ e potência inversa $\left(y=a s^{b}\right)$, nos quais " $y$ " é a incidência da doença, " $a$ ", a interseção da curva na abcissa, " $b$ ", o coeficiente angular e " $s$ ", a distância (metros), foram ajustados aos dados de incidência de plantas doentes e incidência de folhas doentes/planta (notas). Plantas foco foram aquelas com folhas sintomáticas nos segundo e terceiro fluxos vegetativos de cada talhão. Os gradientes de doença foram calculados considerando as incidências de plantas doentes cujos sintomas foram encontrados em fluxos vegetativos imediatamente posteriores aos das plantas foco. As incidências de plantas e de folhas doentes/planta foram calculadas considerando as distâncias, em raios, em relação às plantas foco. As 
plantas adjacentes nas linhas ou entre linhas (direções horizontal, vertical ou diagonal) foram consideradas como pertencentes ao mesmo foco. Os ajustes foram efetuados por regressão não-linear nos quais foi utilizado o programa Statistica 6.0. Na escolha do melhor modelo em cada fluxo vegetativo/talhão foi adotada a metodologia descrita por Campbell \& Madden (1990). Para fins comparativos com Danós et al. (1984) e Gottwald et al. (1988) também foi ajustado o modelo de Gompertz aos dados de incidência de plantas doentes. Nesse caso os gradientes de doença foram calculados por regressão linear entre a proporção transformada de doença $(-\ln (-\ln (y)))$ e o ln da distância da planta foco (Gottwald, 1995; Gottwald et al., 1988).

\subsubsection{Determinação de áreas isópatas}

Mapas de áreas isópatas foram gerados para cada um dos fluxos vegetativos/talhão pelo método de uniformização dos quadrados mínimos das incidências de plantas e de folhas doentes/planta (notas), ponderados pela distância entre plantas (Statistica 6.0). Os incrementos de doença representados em cada mapa foram ajustados para cada caso separadamente, objetivando a melhor visualização da localização e extensão dos focos primários e secundários (Gottwald, 1995). Para a confecção dos mapas foram utilizadas as matrizes dos dados de incidência não transformados.

\subsection{Resultados}

\subsubsection{Incidência de plantas doentes}

$\mathrm{O}$ número de plantas doentes encontradas nos quatorze talhões avaliados variou de uma a 421 e as respectivas incidências foram de 0,17 a 70,76\%. Os mapas de plantas doentes de cada talhão encontram-se nos anexos. Em seis talhões foram encontradas plantas com sintomas de cancro cítrico no primeiro fluxo vegetativo (talhões 2, 3, 5, 8, 22 e 25) (Tabela 1 e Figura 1). Três talhões (4, 6 e 20) foram 







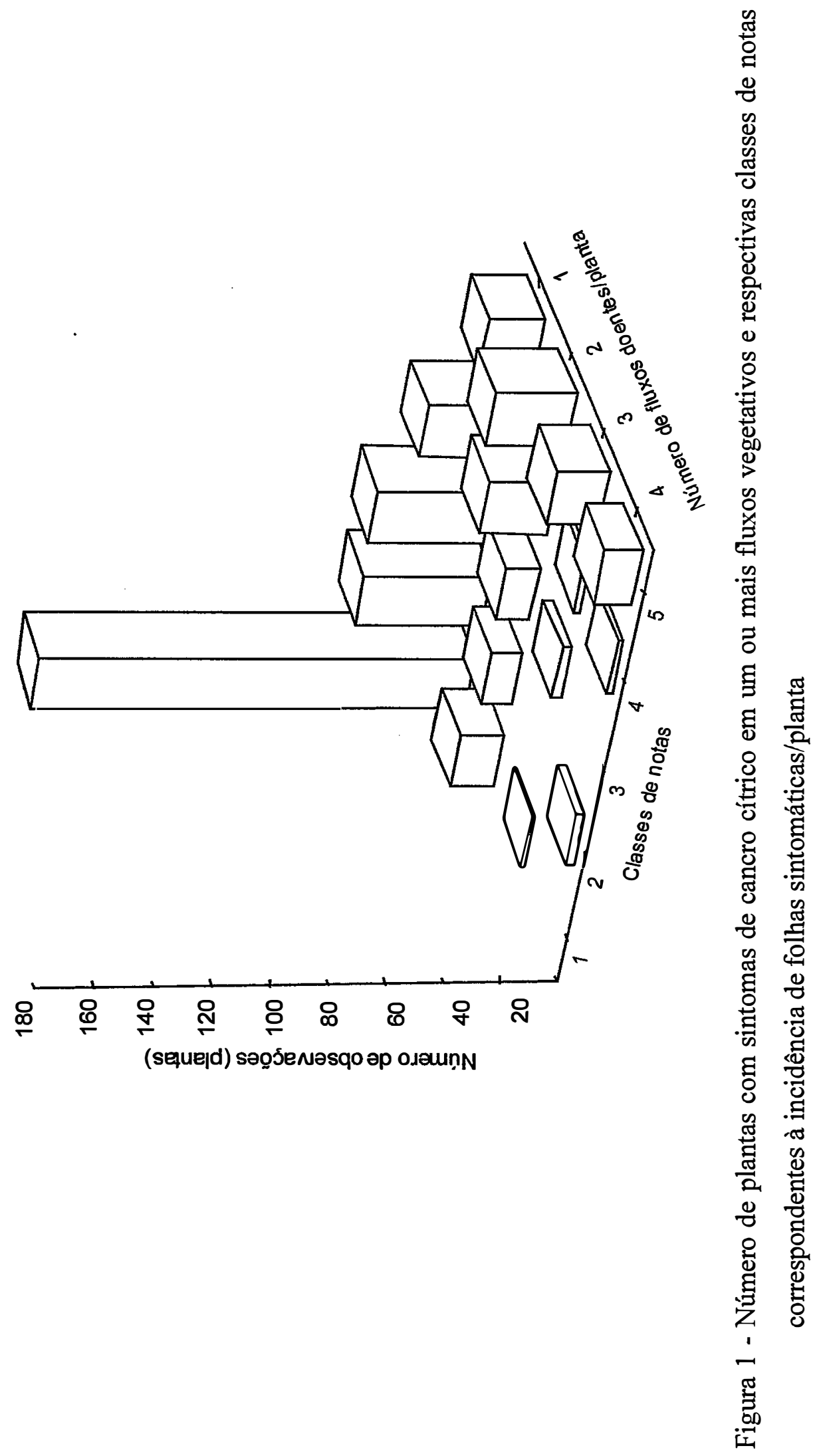


infectados quando as plantas encontravam-se no terceiro fluxo vegetativo e outros quatro talhões $(7,15,24$ e 26) quando as plantas continham quatro fluxos vegetativos. Aproximadamente $70 \%$ das plantas apresentavam sintomas apenas no último fluxo vegetativo, enquanto $20,78 \%$ apresentavam sintomas em dois fluxos, $5,48 \%$ em três e $4,11 \% \mathrm{em}$ todos os fluxos. Considerando todas as plantas doentes avaliadas quanto aos fluxos vegetativos doentes 39,$73 ; 13,70 ; 14,16 ; 14,38$ e $18,04 \%$ receberam as notas um a cinco, respectivamente (Figura 1).

Foi observada uma relação linear entre o número de fluxos vegetativos sintomáticos e a nota recebida por cada planta $\left(\mathrm{F}=149,09 ; p=1,07 \times 10^{-29}\right)$, mas com baixo coeficiente de determinação $\left(R^{2}=0,26\right)$ (dados não mostrados). De um modo geral, plantas doentes há mais tempo receberam as maiores notas, mas o inverso (plantas com infecção recente e notas altas) também ocorreu, por isso o baixo coeficiente de determinação da regressão linear. Também foi observada uma relação direta entre as incidências de plantas doentes e de folhas/planta (notas) (Figura 2), tanto considerando os quatorze talhões avaliados (Figura 2A) quanto somente os talhões com as menores incidências (Figura 2B). Quanto maior o número de plantas doentes observadas em um talhão, maior foi o número de folhas sintomáticas/planta, como também observado por Gottwald et al. (2002b).

\subsubsection{Análise de seqüências ordinárias}

Em razão do pequeno número de plantas inicialmente contaminadas em cada talhão (uma a três), o padrão de agregação observado no primeiro fluxo vegetativo sintomático foi de ocorrência de plantas doentes ao acaso (Tabela 2). Após o aumento do número de plantas contaminadas em cada talhão ocorreram padrões de agregação. Valores de $\mathrm{Z}$ mais negativos (maior agregação de plantas doentes) ocorreram ao longo das linhas, em comparação com a agregação observada entre linhas de plantas. 

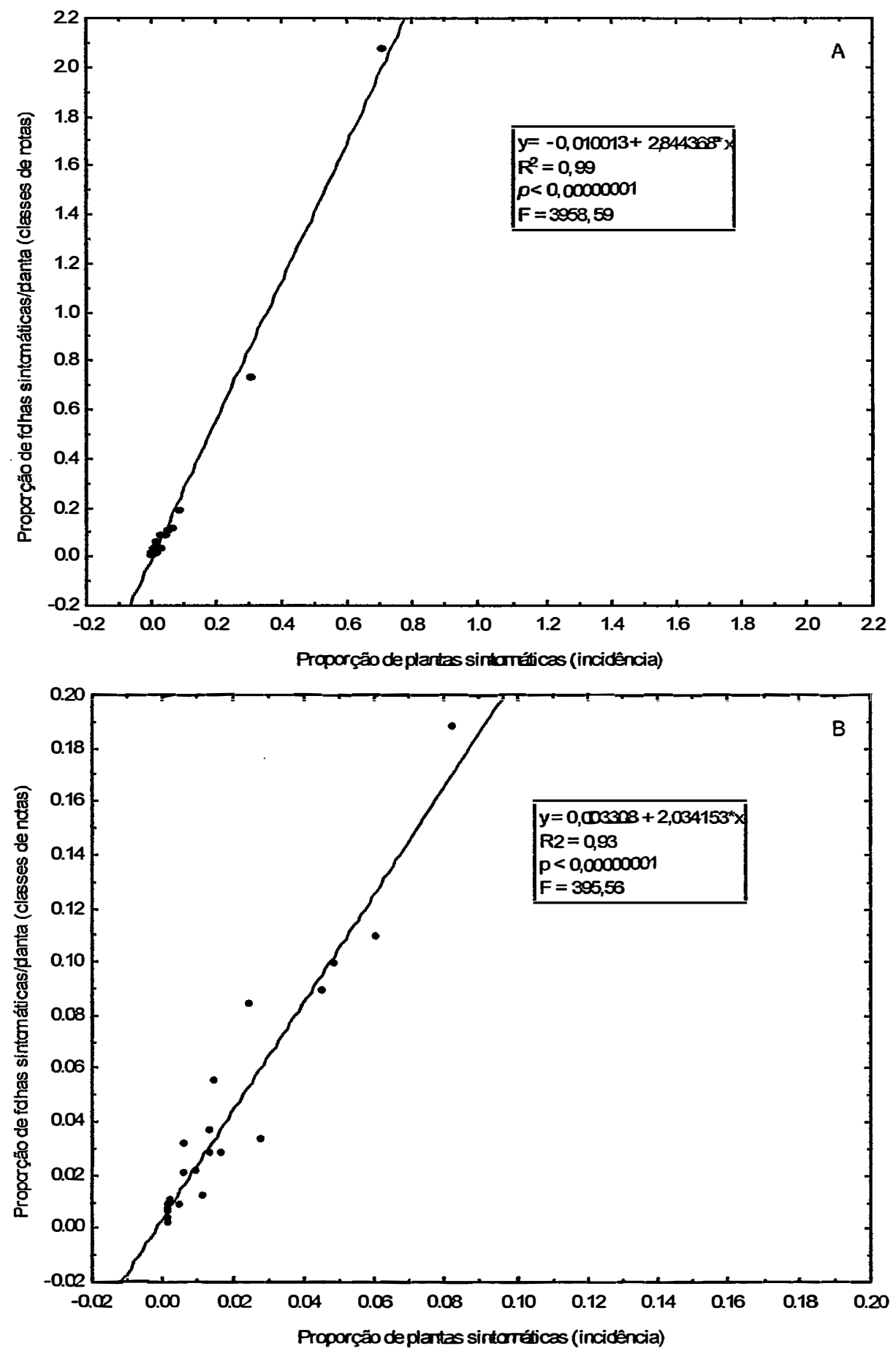

Figura 2 - Relação linear entre as incidências de plantas e de folhas sintomáticas/planta (classes de notas) considerando todo o conjunto de dados (A) e excluindo-se os talhões com as maiores incidências (talhões 1 e 3) (B) 


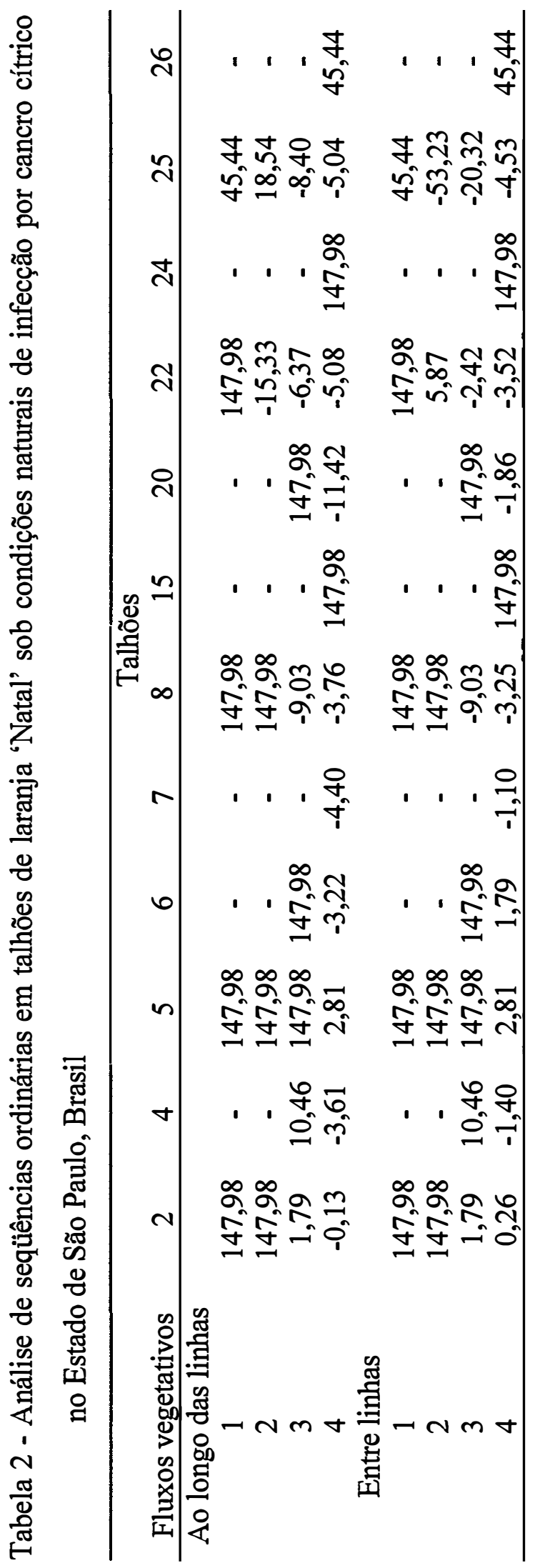




\subsubsection{Dinâmica e estrutura de focos}

A análise da dinâmica e estrutura de focos revelou maiores incrementos no NF, principalmente, no quarto fluxo vegetativo, em comparação com os fluxos vegetativos anteriores. Foram observados também incrementos no NFU e no NMPF (Tabela 3). Considerando todo o conjunto de dados, regressões lineares entre as variáveis da dinâmica e estrutura de focos e a incidência de plantas doentes, revelaram que o aumento do NMPF explicou mais fielmente o incremento observado na incidência de plantas doentes que as demais variáveis $\left(\mathrm{F}=63,95\right.$ e $\left.p=3,18 \times 10^{-8}\right)$, apesar dos altos NFU ocorridos no quarto fluxo vegetativo em sete dos doze talhões (Tabelas 3 e 4).

\subsubsection{Distâncias entre plantas doentes}

A menor distância observada entre plantas doentes foi de $3,50 \mathrm{~m}$, que era a distância mínima entre plantas, e a máxima de $177,16 \mathrm{~m}$, ocorrida na comparação das distâncias entre as plantas dos terceiro e quarto fluxos vegetativos do talhão 25 (Tabela 5). Maiores distâncias foram observadas entre plantas doentes de um mesmo fluxo vegetativo. As distâncias médias variaram de 4,38 metros, observada no talhão 8, a 83,08 metros, no talhão 4. As distâncias média e máxima ocorridas entre plantas doentes de fluxos diferentes foram maiores a cada novo fluxo vegetativo, como observado nos talhões 2, 8, 22 e 25 (Tabela 5).

Considerando as comparações entre fluxos vegetativos, a aplicação de um raio de trinta metros de erradicação englobaria entre 11,90 e $100 \%$ das distâncias observadas entre plantas doentes (Tabela 6). Estes valores variaram entre talhões e também entre fluxos vegetativos, e no quarto fluxo vegetativo no máximo 73,33\% das distâncias eram iguais ou inferiores a trinta metros, considerando os oito talhões que apresentaram plantas sintomáticas em mais de um fluxo vegetativo. Seriam necessários raios de oito e 91,90 metros, a partir das plantas consideradas foco (sintomáticas em fluxos anteriores), para englobar $90 \%$ das distâncias calculadas, e de oito a 165,56 metros para englobar-se 


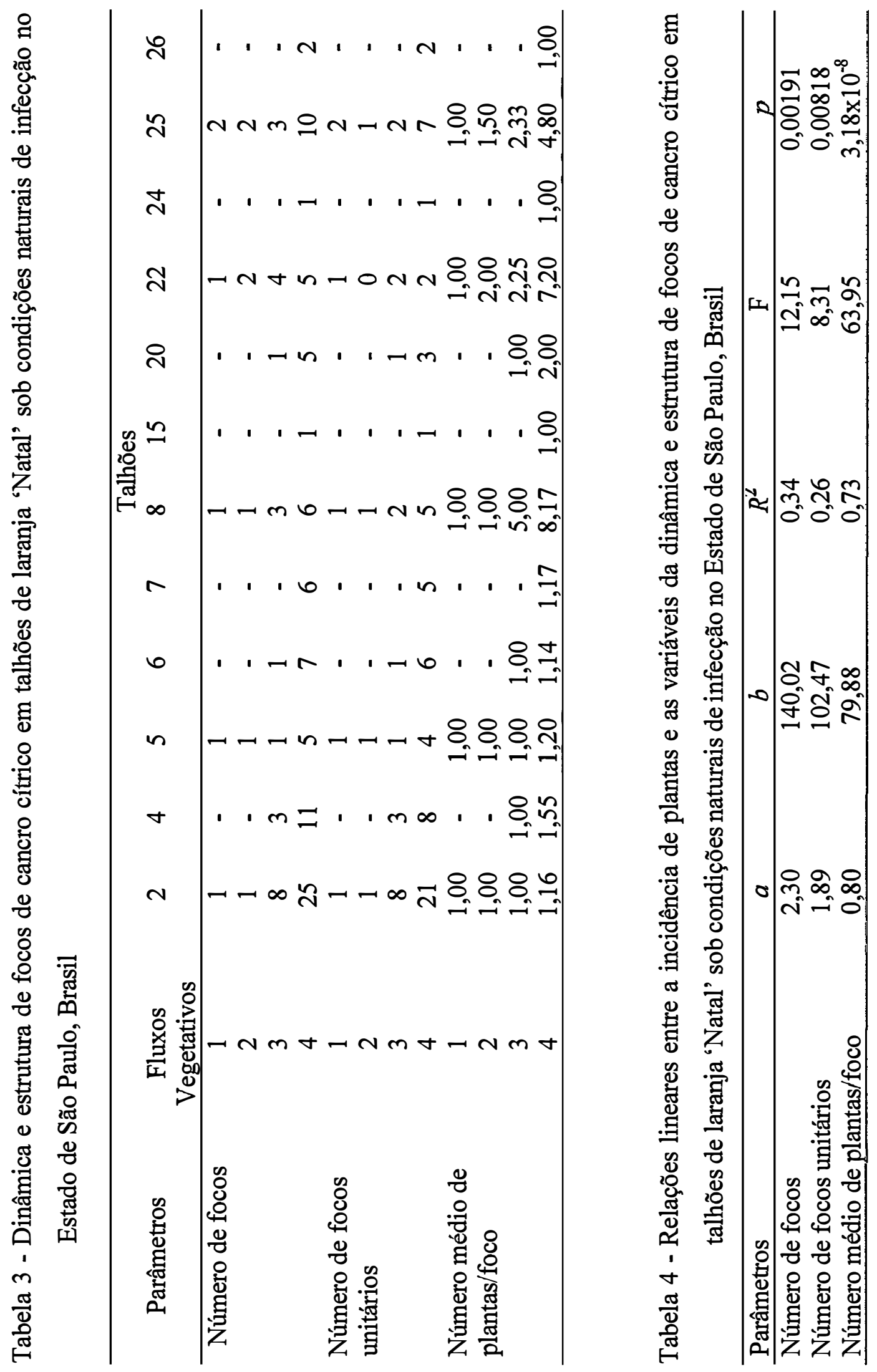


Tabela 5 - Distâncias entre plantas com cancro cítrico em diferentes fluxos vegetativos, e entre fluxos vegetativos, em talhões de laranja 'Natal' sob condições naturais de infecção no Estado de São Paulo, Brasil

\begin{tabular}{|c|c|c|c|}
\hline \multirow{2}{*}{$\begin{array}{c}\text { Talhões e } \\
\text { fluxos vegetativos }\end{array}$} & \multicolumn{3}{|c|}{ Distâncias entre plantas doentes (metros) } \\
\hline & Mínima & Máxima & Média \pm erro padrão \\
\hline \multicolumn{4}{|l|}{ Talhão 2} \\
\hline Fluxo $3^{a}$ & 18,85 & 105,00 & $59,83 \pm 25,51$ \\
\hline Fluxo $3 \times$ fluxo $1^{b}$ & 12,62 & 75,39 & $42,77 \pm 24,37$ \\
\hline Fluxo 4 & 3,50 & 129,07 & $51,26 \pm 24,63$ \\
\hline Fluxo $4 \mathrm{x}$ fluxo 3 & 7,83 & 106,45 & $53,08 \pm 24,48$ \\
\hline \multicolumn{4}{|l|}{ Talhão 4} \\
\hline Fluxo 3 & $10 ; 50$ & 28,00 & $18,67 \pm 8,81$ \\
\hline Fluxo 4 & 3,50 & 100,77 & $44,72 \pm 28,86$ \\
\hline Fluxo 4 x fluxo 3 & 3,50 & 108,73 & $51,87 \pm 22,17$ \\
\hline \multicolumn{4}{|l|}{ Talhão 5} \\
\hline Fluxo 4 & 21,29 & 84,29 & $48,32 \pm 20,00$ \\
\hline Fluxo 4 x fluxo 1 & 7,83 & 91,87 & $55,57 \pm 32,05$ \\
\hline \multicolumn{4}{|l|}{ Talhão 6} \\
\hline Fluxo 4 & 3,50 & 123,30 & $54,67 \pm 29,21$ \\
\hline Fluxo 4 x fluxo 3 & 17,50 & 81,93 & $44,20 \pm 26,90$ \\
\hline \multicolumn{4}{|l|}{ Talhão 7} \\
\hline Fluxo 4 & 3,50 & 148,82 & $83,08 \pm 35,83$ \\
\hline \multicolumn{4}{|l|}{ Talhão 8} \\
\hline Fluxo 3 & 3,50 & 67,96 & $20,40 \pm 16,73$ \\
\hline Fluxo $3 \mathrm{x}$ fluxo 1 & 3,50 & 47,09 & $4,38 \pm 11,00$ \\
\hline Fluxo 4 & 3,50 & 108,67 & $26,30 \pm 18,81$ \\
\hline Fluxo 4 x fluxo 3 & 3,50 & 105,52 & $25,54 \pm 16,70$ \\
\hline \multicolumn{4}{|l|}{ Talhão 20} \\
\hline Fluxo 4 & 3,50 & 90,80 & $53,17 \pm 32,32$ \\
\hline Fluxo 4 x fluxo 3 & 3,50 & 91,00 & $57,07 \pm 37,62$ \\
\hline \multicolumn{4}{|l|}{ Talhão 22} \\
\hline Fluxo 2 & 3,50 & 18,85 & $12,67 \pm 8,10$ \\
\hline Fluxo 2 x fluxo 1 & 7,83 & 21,00 & $15,44 \pm 6,82$ \\
\hline Fluxo 3 & 9,90 & 47,61 & $25,31 \pm 11,37$ \\
\hline Fluxo 3 x fluxo 2 & 3,50 & 35,00 & $18,11 \pm 9,46$ \\
\hline Fluxo 4 & 3,50 & 70,00 & $27,00 \pm 14,91$ \\
\hline Fluxo 4 x fluxo 3 & 3,50 & 75,72 & $24,87 \pm 14,81$ \\
\hline \multicolumn{4}{|l|}{ Talhão 25} \\
\hline Fluxo 1 & 10,63 & 10,63 & $10,63 \pm 0,00$ \\
\hline Fluxo 2 x fluxo 1 & 7,00 & 8,00 & $7,50 \pm 0,71$ \\
\hline Fluxo 3 & 4,00 & 27,78 & $14,86 \pm 8,90$ \\
\hline Fluxo 3 x fluxo 2 & 7,00 & 24,19 & $15,79 \pm 5,20$ \\
\hline Fluxo 4 & 4,00 & 186,81 & $42,03 \pm 36,85$ \\
\hline Fluxo 4 x fluxo 3 & 4,00 & 177,16 & $34,56 \pm 32,93$ \\
\hline \multicolumn{4}{|l|}{ Talhão 26} \\
\hline Fluxo 4 & 21,00 & 21,00 & $21,00 \pm 0,00$ \\
\hline
\end{tabular}


${ }^{b}$ refere-se as distâncias de todas as combinações possíveis entre as plantas doentes no terceiro fluxo vegetativo em relação as plantas doentes no primeiro fluxo vegetativo.

Tabela 6 - Porcentagem de distâncias menores ou iguais a trinta metros entre plantas com sintomas de cancro cítrico, na comparação entre fluxos vegetativos, e distâncias (raios) necessárias para englobar 50, 70, 90 e 99\% das distâncias calculadas entre plantas de laranja 'Natal' sintomáticas e sob condições naturais de infeç̧ão no Estado de São Paulo, Brasil

\begin{tabular}{|c|c|c|c|c|c|}
\hline \multirow{2}{*}{$\begin{array}{c}\text { Talhões e } \\
\text { fluxos vegetativos }\end{array}$} & \multirow{2}{*}{$\begin{array}{l}\text { \% distâncias } \\
\text { até } 30 \text { metros }\end{array}$} & \multicolumn{4}{|c|}{ Distâncias (raios, em metros) necessárias para englobar } \\
\hline & & $50 \%$ & $70 \%$ & $90 \%$ & $99 \%$ \\
\hline \multicolumn{6}{|l|}{ Talhão 2} \\
\hline Fluxo $3 \times$ fluxo 1 & 28,57 & 37,7 & 66,87 & 75,39 & 75,39 \\
\hline Fluxo 4 x fluxo 3 & 18,45 & 52,03 & 66,40 & 86,66 & 104,60 \\
\hline \multicolumn{6}{|l|}{ Talhão 4} \\
\hline Fluxo 4 x fluxo 3 & 11,90 & 50,48 & 59,50 & 75,39 & 108,73 \\
\hline \multicolumn{6}{|l|}{ Talhão 5} \\
\hline Fluxo 4 x fluxo 1 & 20,00 & 59,91 & 74,41 & 91,87 & 91,87 \\
\hline \multicolumn{6}{|l|}{ Talhão 6} \\
\hline Fluxo 4 x fluxo 3 & 57,10 & 28,86 & 59,50 & 81,93 & 81,93 \\
\hline \multicolumn{6}{|l|}{ Talhão 8} \\
\hline Fluxo $3 \times$ fluxo 1 & 92,86 & 14,43 & 21,29 & 22,14 & 47,09 \\
\hline Fluxo 4 x fluxo 3 & 73,33 & 22,14 & 28,86 & 43,85 & 98,25 \\
\hline \multicolumn{6}{|l|}{ Talhão 20} \\
\hline Fluxo 4 x fluxo 3 & 44,40 & 75,72 & 84,58 & 91,00 & 91,00 \\
\hline \multicolumn{6}{|l|}{ Talhão 22} \\
\hline Fluxo 2 x fluxo 1 & 100,00 & 17,50 & 21,00 & 21,00 & 21,00 \\
\hline Fluxo $3 \times$ fluxo 2 & 85,00 & 15,65 & 22,14 & 31,30 & 35,00 \\
\hline Fluxo 4 x fluxo 3 & 68,72 & 22,41 & 31,30 & 45,50 & 64,25 \\
\hline \multicolumn{6}{|l|}{ Talhão 25} \\
\hline Fluxo 2 x fluxo 1 & 100,00 & 8,00 & 8,00 & 8,00 & 8,00 \\
\hline Fluxo $3 \times$ fluxo 2 & 100,00 & 14,56 & 20,00 & 21,38 & 24,19 \\
\hline Fluxo $4 \mathrm{x}$ fluxo 3 & 61,56 & 24,19 & 35,00 & 68,36 & 165,56 \\
\hline
\end{tabular}

99\% das distâncias. Considerando os fluxos anteriores ao quarto, foram observadas distâncias menores que trinta metros nos talhões com até $0,5 \%$ de incidência (talhão 4/fluxo 3 e 25/fluxo 2), e também o talhão 22/fluxo 2, com incidência de $0,67 \%$ e distância máxima de 21,00 metros. 
De modo geral, no terceiro fluxo vegetativo a freqüência de plantas doentes (em número de casos observados) foi homogeneamente distribuída em diferentes classes de distância, sem que ocorresse uma classe predominante (Figura 3). Esse padrão resultou em freqüências baixas em várias classes de distância. A máxima freqüência observada entre plantas doentes foi dezoito, ocorrida no talhão 8 na classe de distância de 17,5 metros. Muitas das plantas doentes observadas nesse fluxo vegetativo ocorreram na freqüência um, ou seja, a cada classe de distância considerada, que variou de 3,5 a 105 metros, existia apenas um caso ou uma combinação de distância entre duas plantas doentes. Maiores freqüências foram observadas no quarto fluxo vegetativo, as quais variaram de um nas classes de distâncias mais elevadas, a cem, observada a 24,5 metros no talhão 25 (Figura 4). Nos talhões 8 e 25 a maioria das plantas estava mais concentrada a distâncias até sessenta metros, em comparação às distância máximas observadas nesses dois talhões, as quais foram de 112 e 189 metros, respectivamente. Talhões com maiores incidências de plantas doentes, como por exemplo os talhões 2,8 , 22 e 25 (Figuras 3 e 4), apresentaram maiores freqüências em diferentes classes de distâncias que talhões com menores incidências de plantas (4, 5, 6 e 20, Figura 5), mas distâncias igualmente longas, próximas a cem metros, ocorreram para ambos os casos.

Regressões lineares entre a incidência de plantas doentes no talhão e as distâncias mínimas, médias e máximas observadas resultaram em valores de $p>0,19$, não indicando a existência de uma relação direta entre a incidência da doença e as distâncias entre plantas doentes (dados não mostrados). Quando considerou-se as plantas doentes existentes no segundo e terceiro fluxos vegetativos como sendo as plantas foco das plantas doentes observadas nos terceiro e quarto fluxos, respectivamente, as freqüências e as classes de distância observadas praticamente não foram alteradas (Figuras 6 a 8). Da mesma forma como observado entre plantas de um mesmo fluxo vegetativo, baixas freqüências ocorreram em diferentes classes de distância entre plantas de fluxos diferentes, sem a predominância de alguma determinada classe. $O$ talhão 2 pode ser usado como exemplo, no qual foi observado freqüência um para todas as classes de distância ocorridas, que variaram de 14 a 77 metros (Figura 6A). De fato, este talhão foi um dos que apresentou o padrão de agregação de plantas doentes 

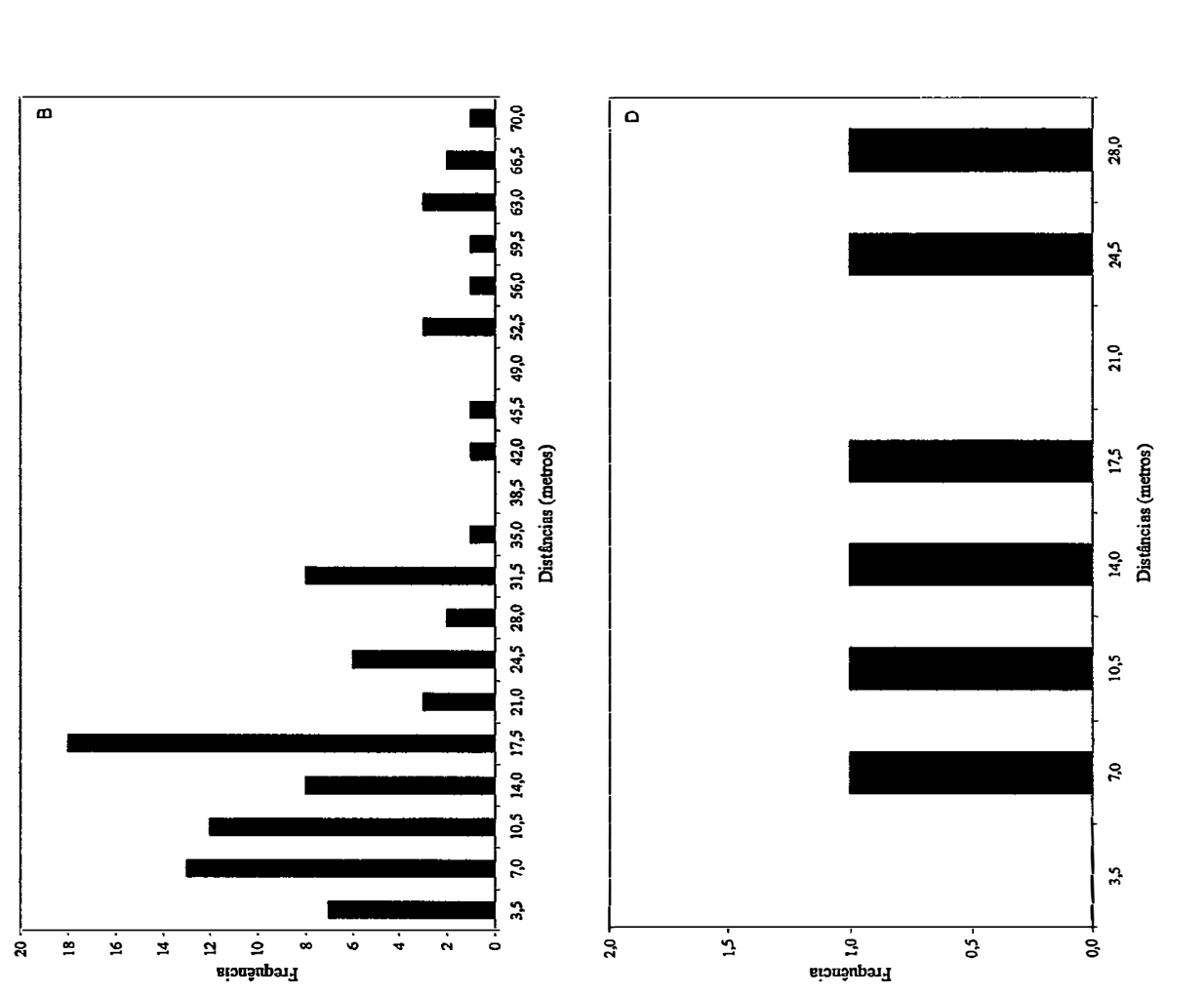

年
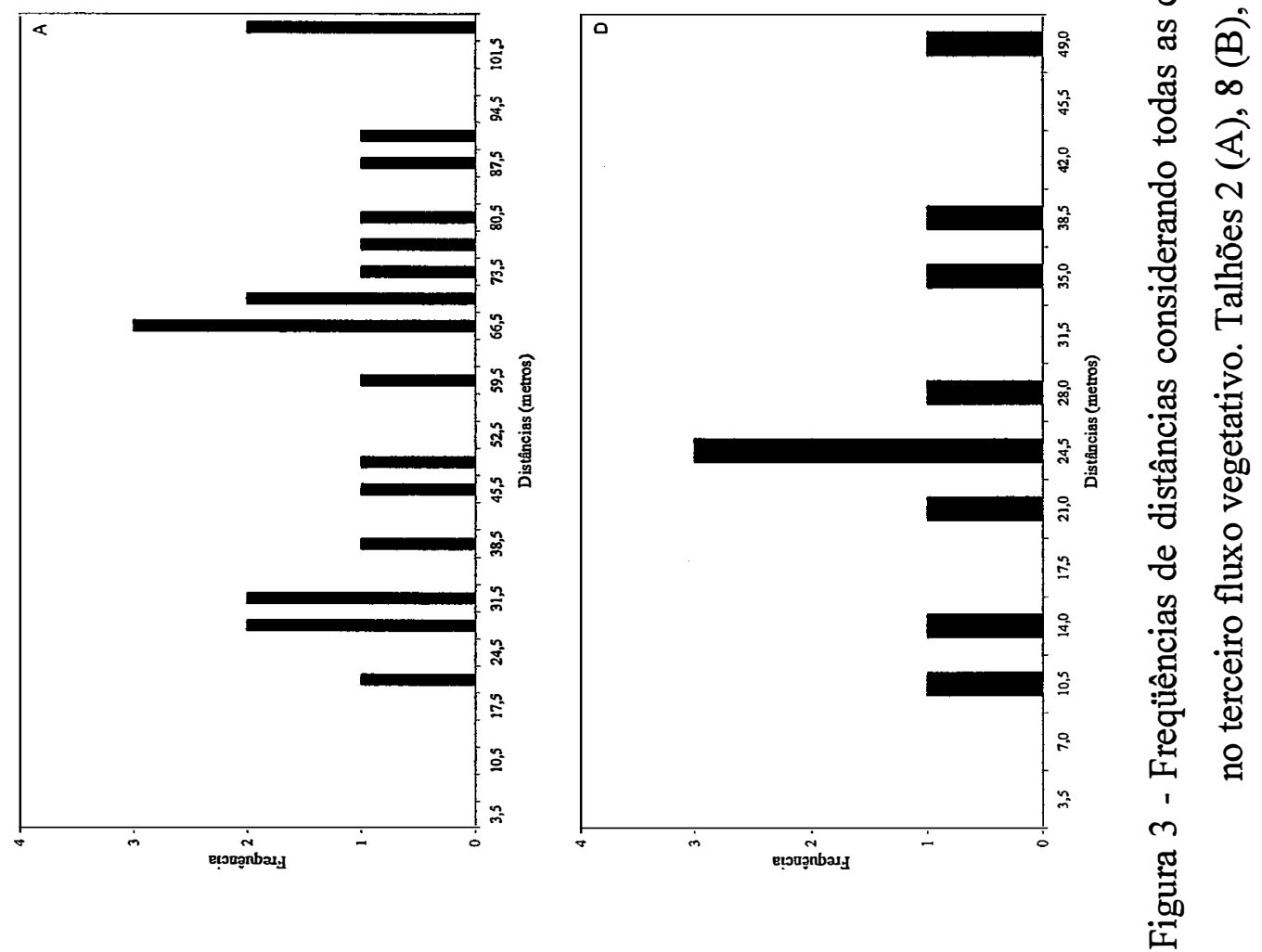

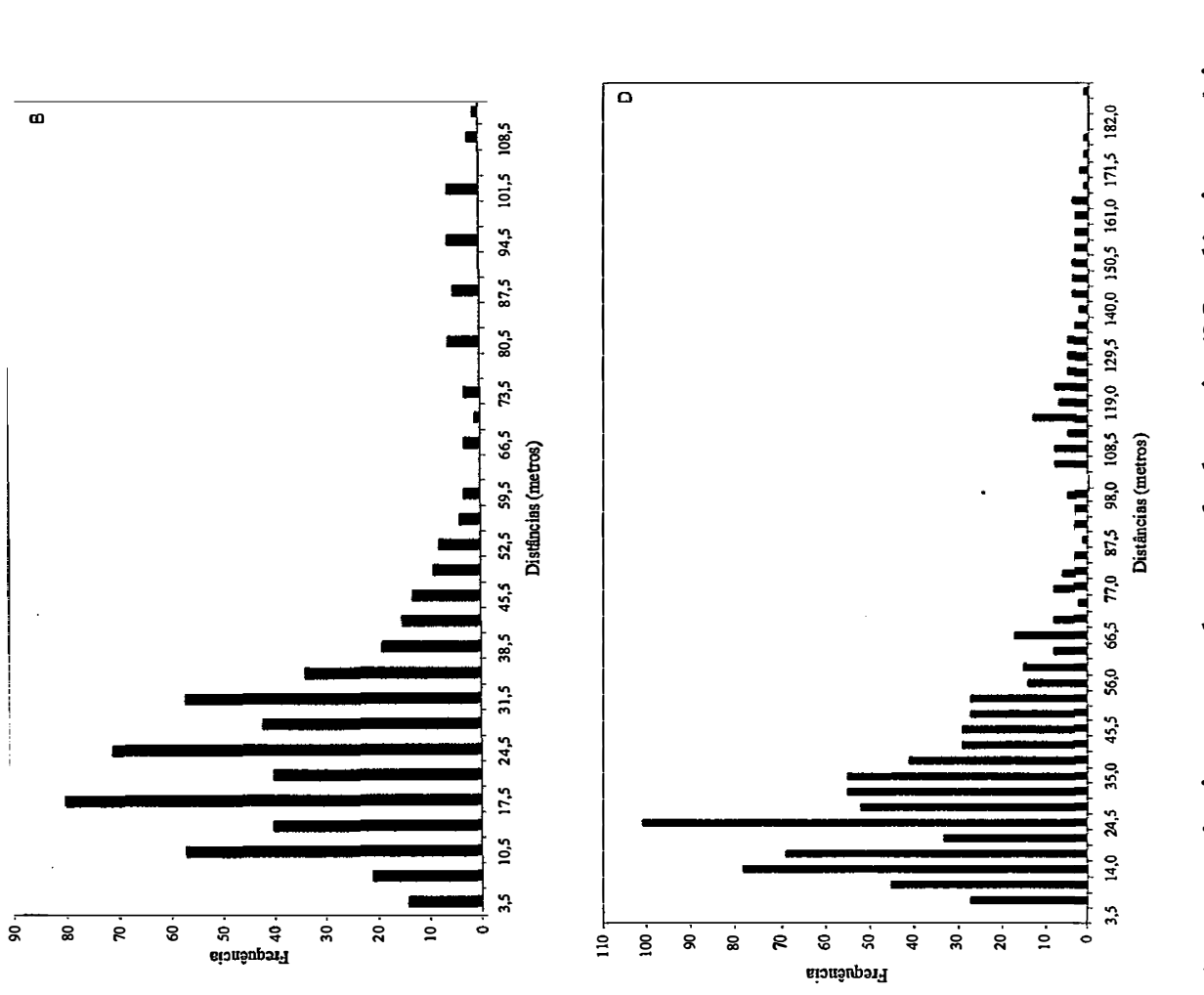

U.
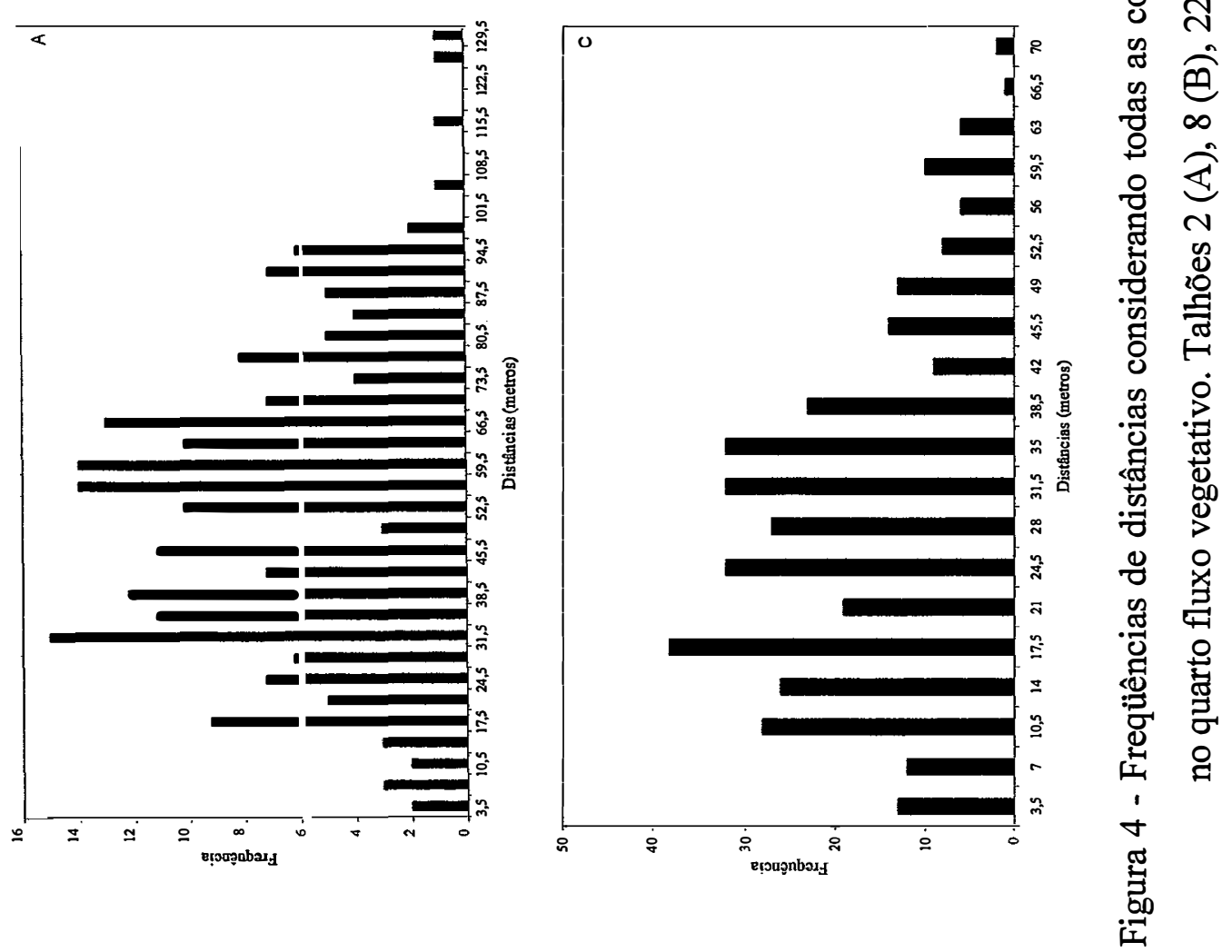

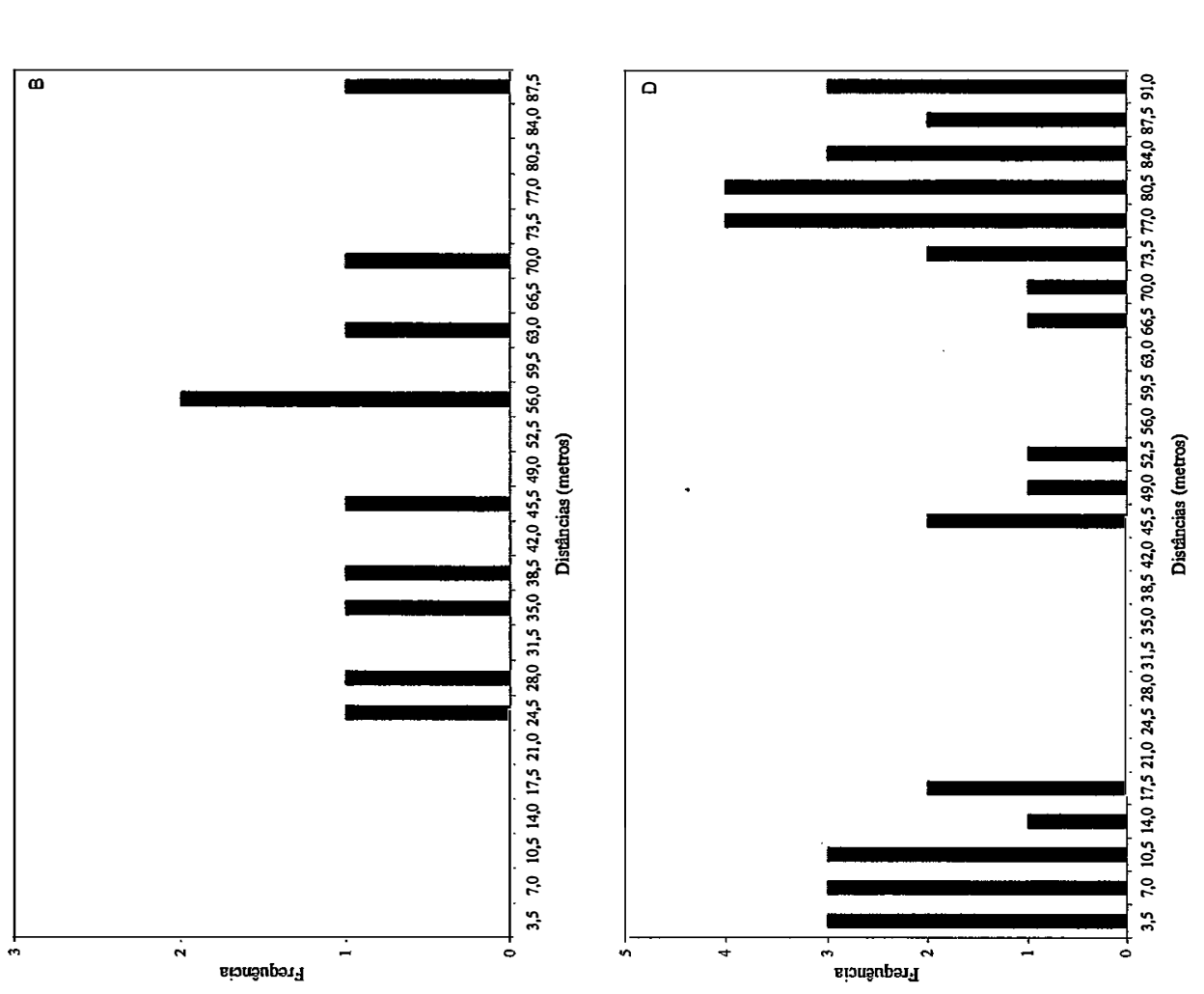

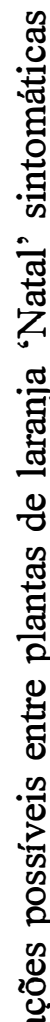

હิ
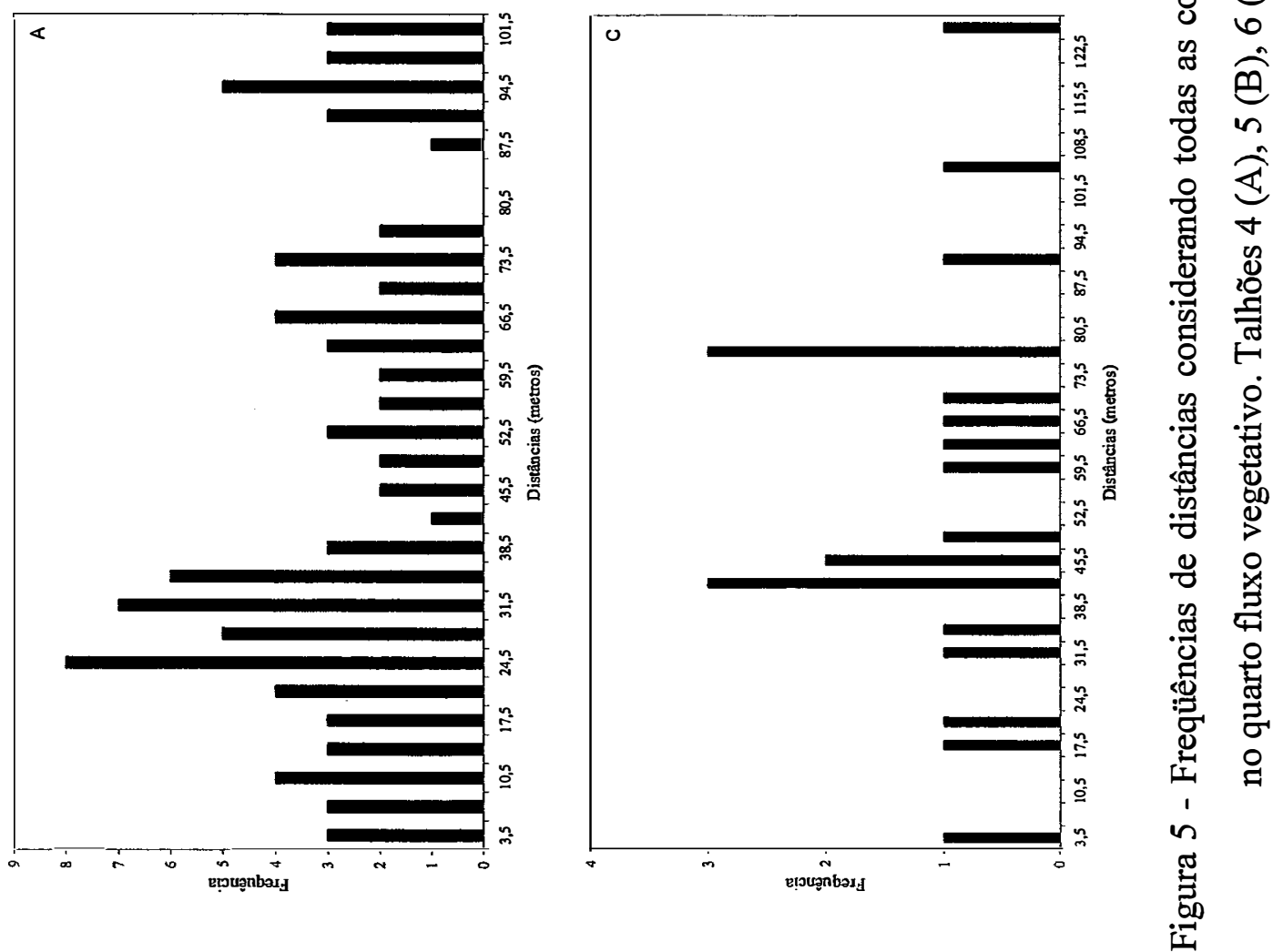

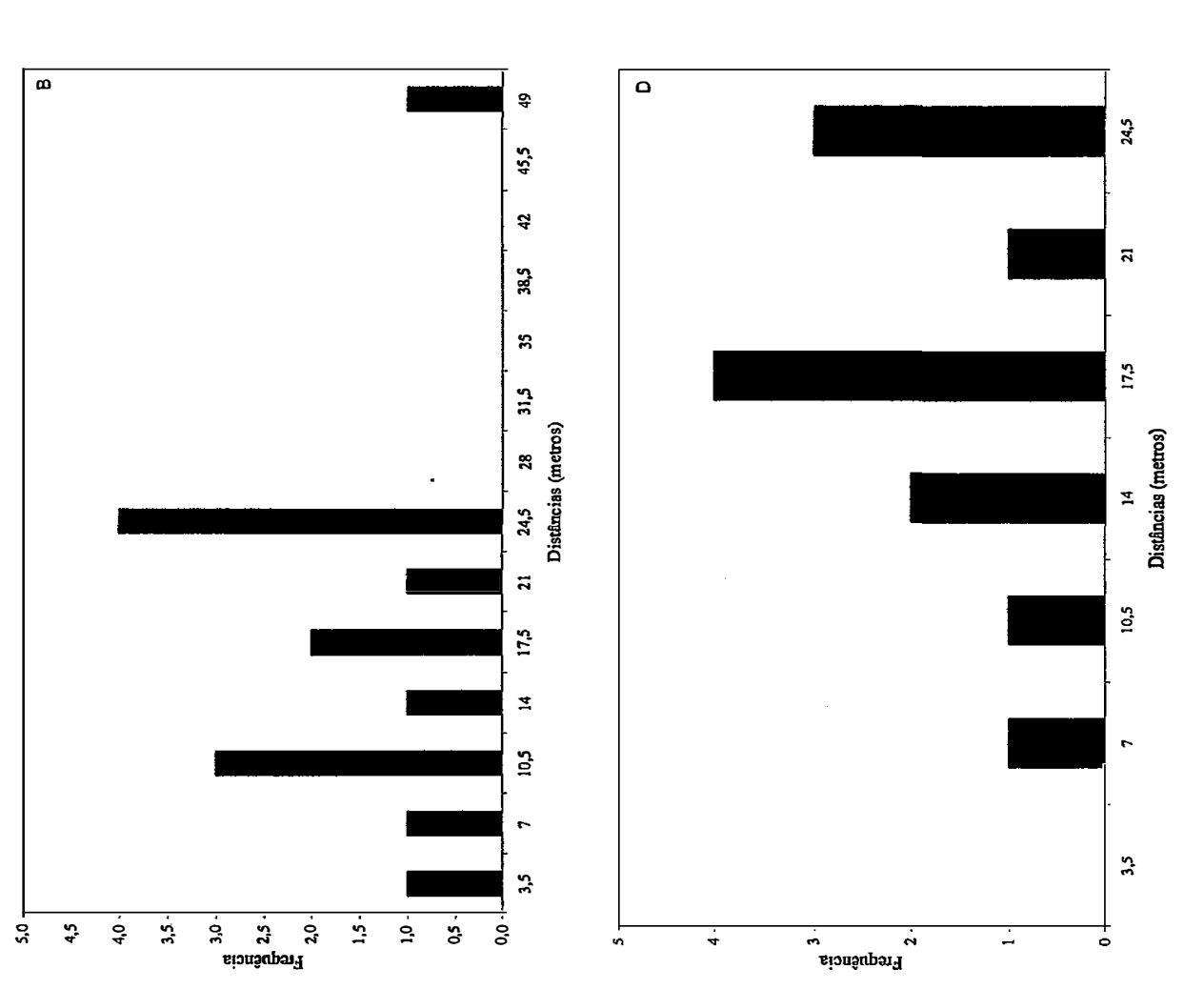

.
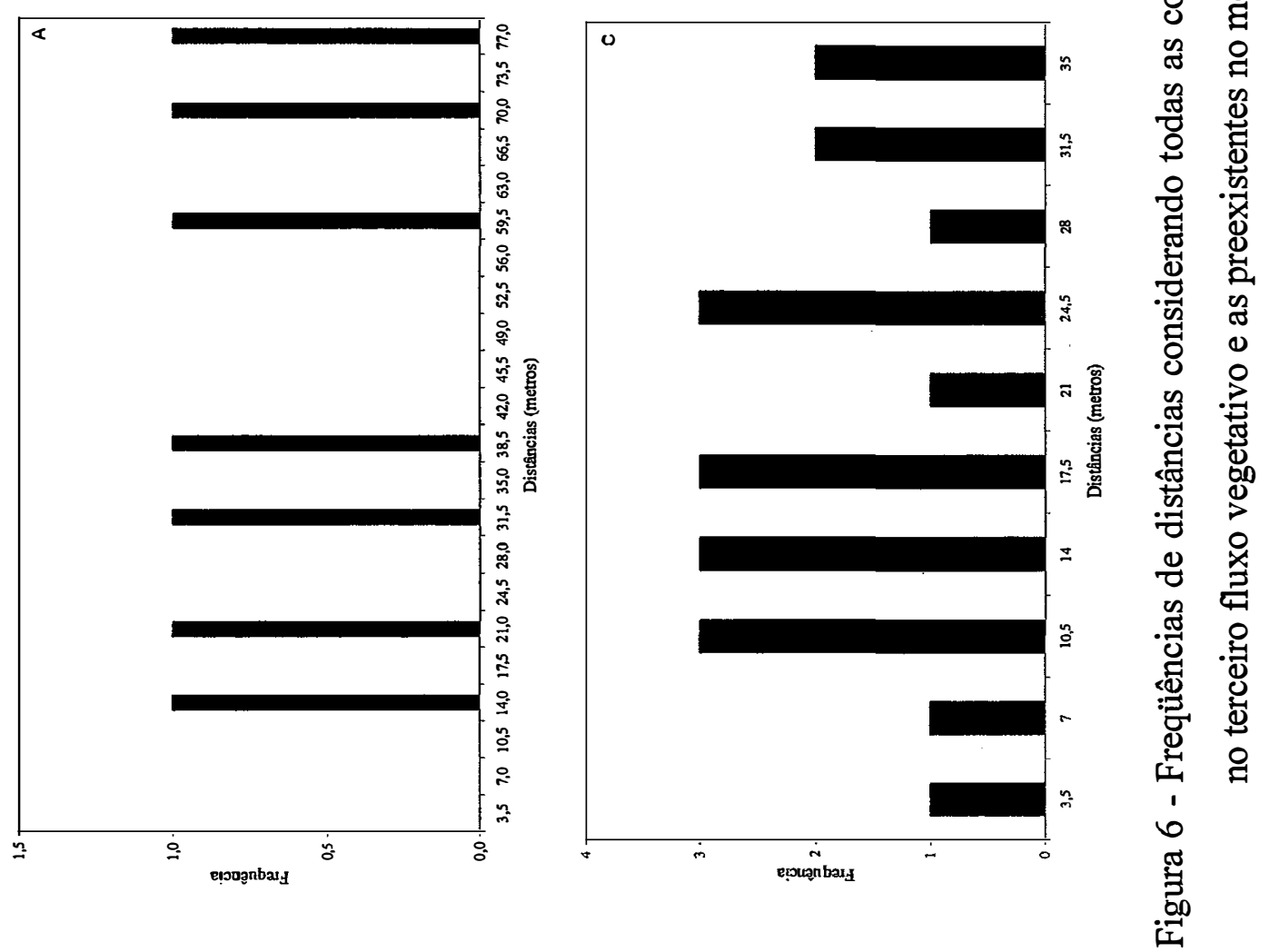

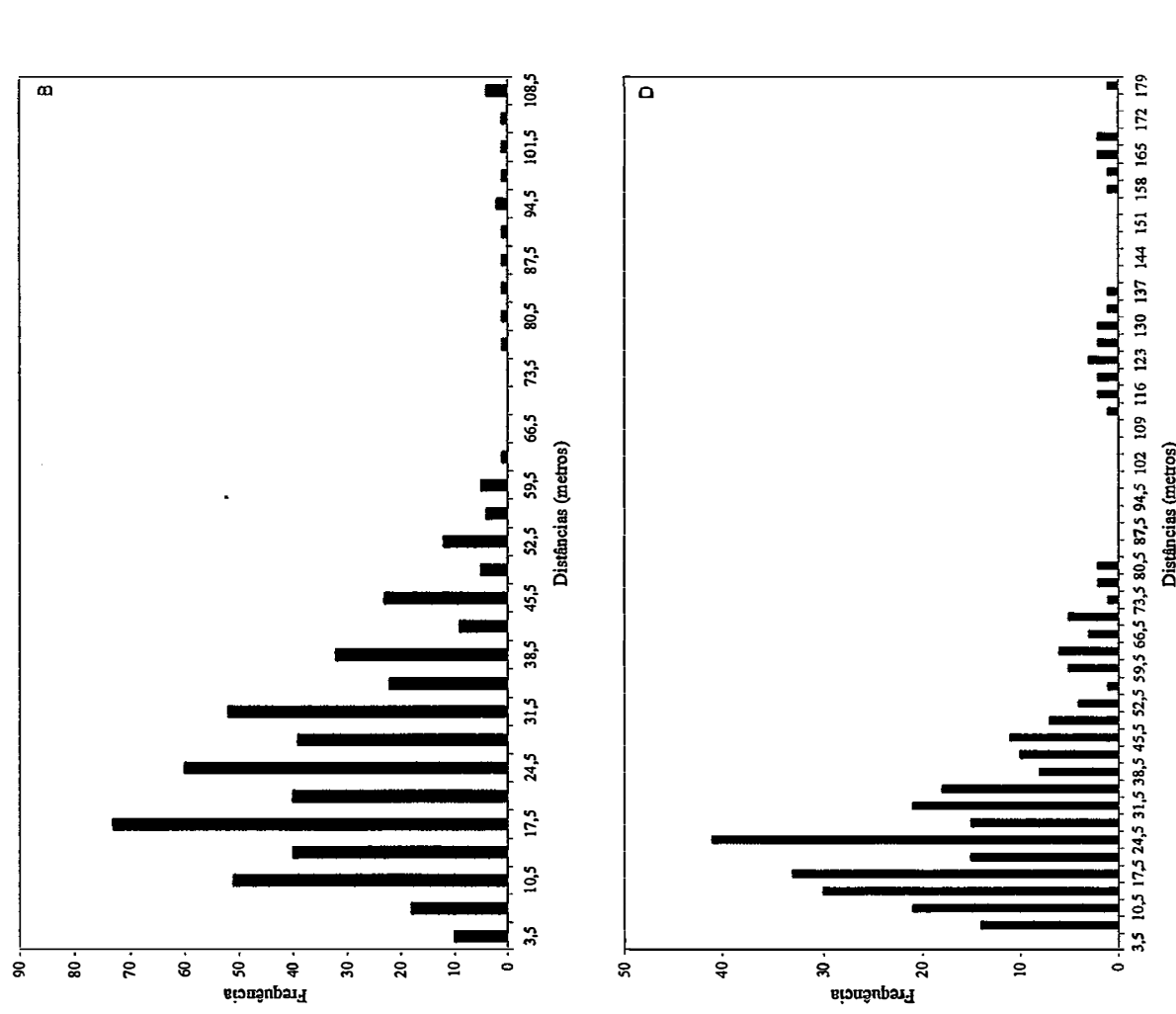

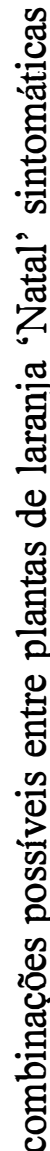
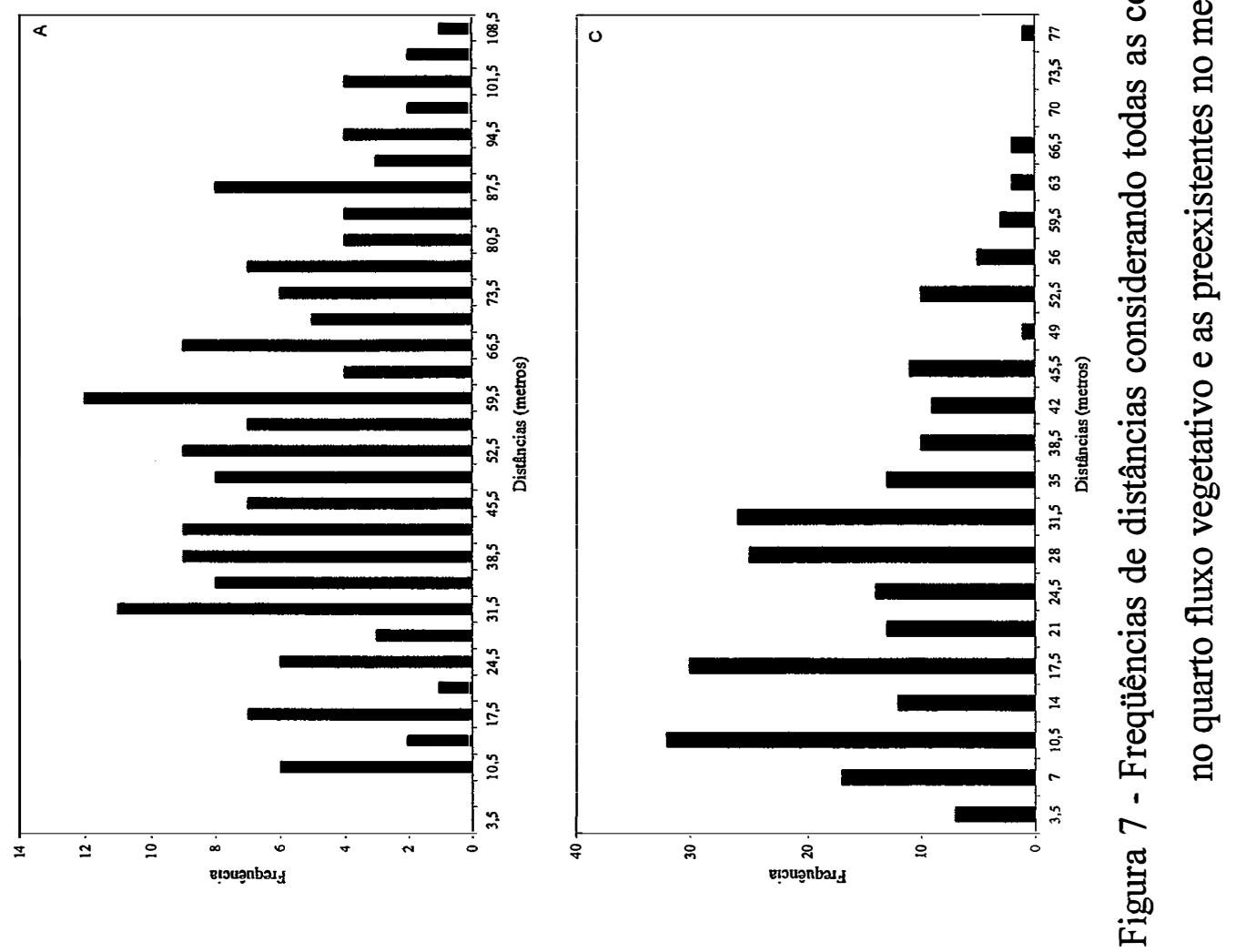

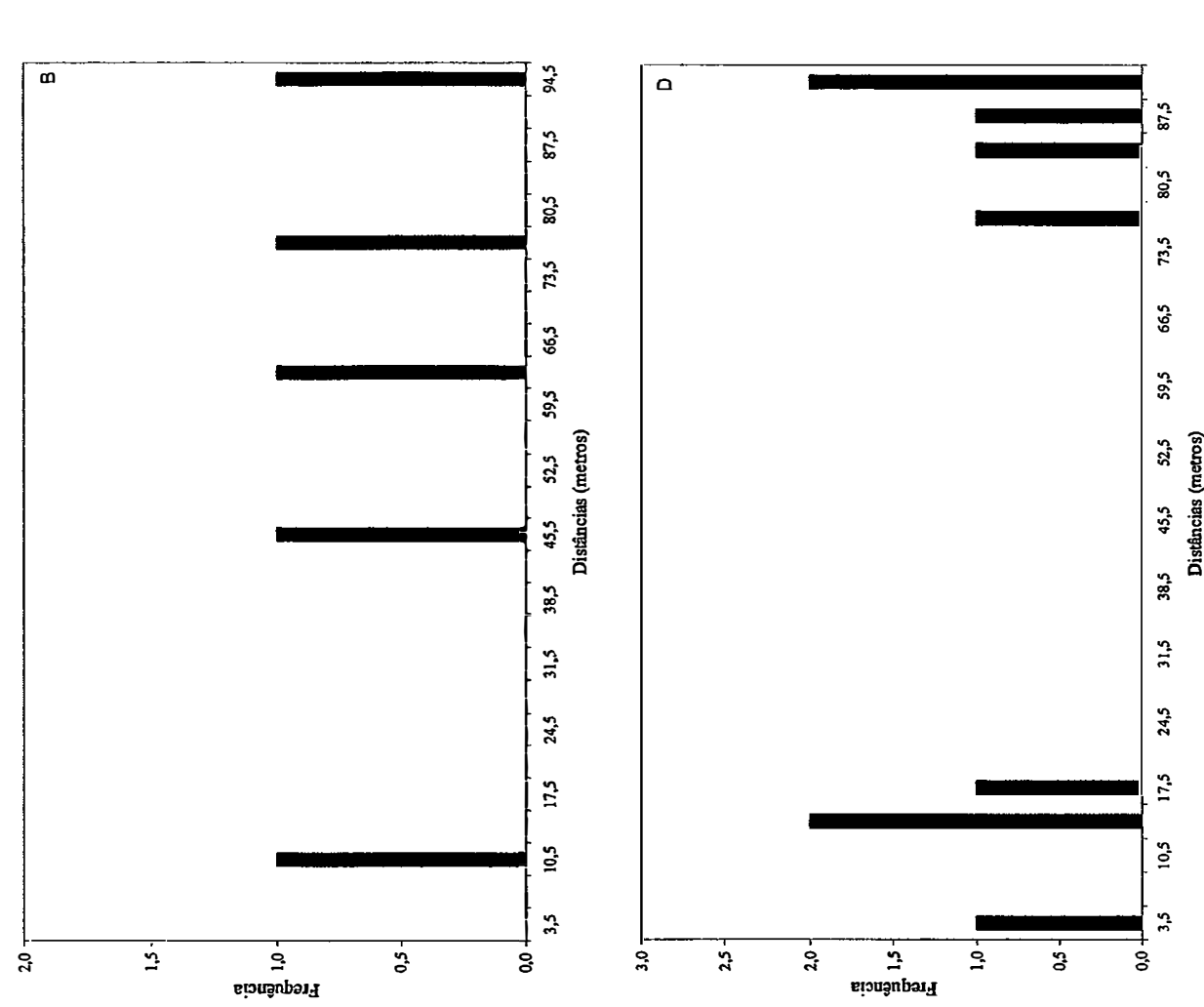

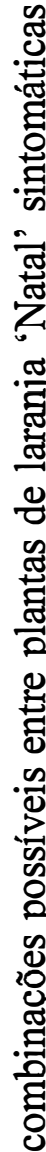

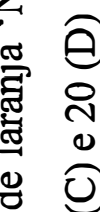

离

6

กิ

in

壱

电 $\forall$

\&

त

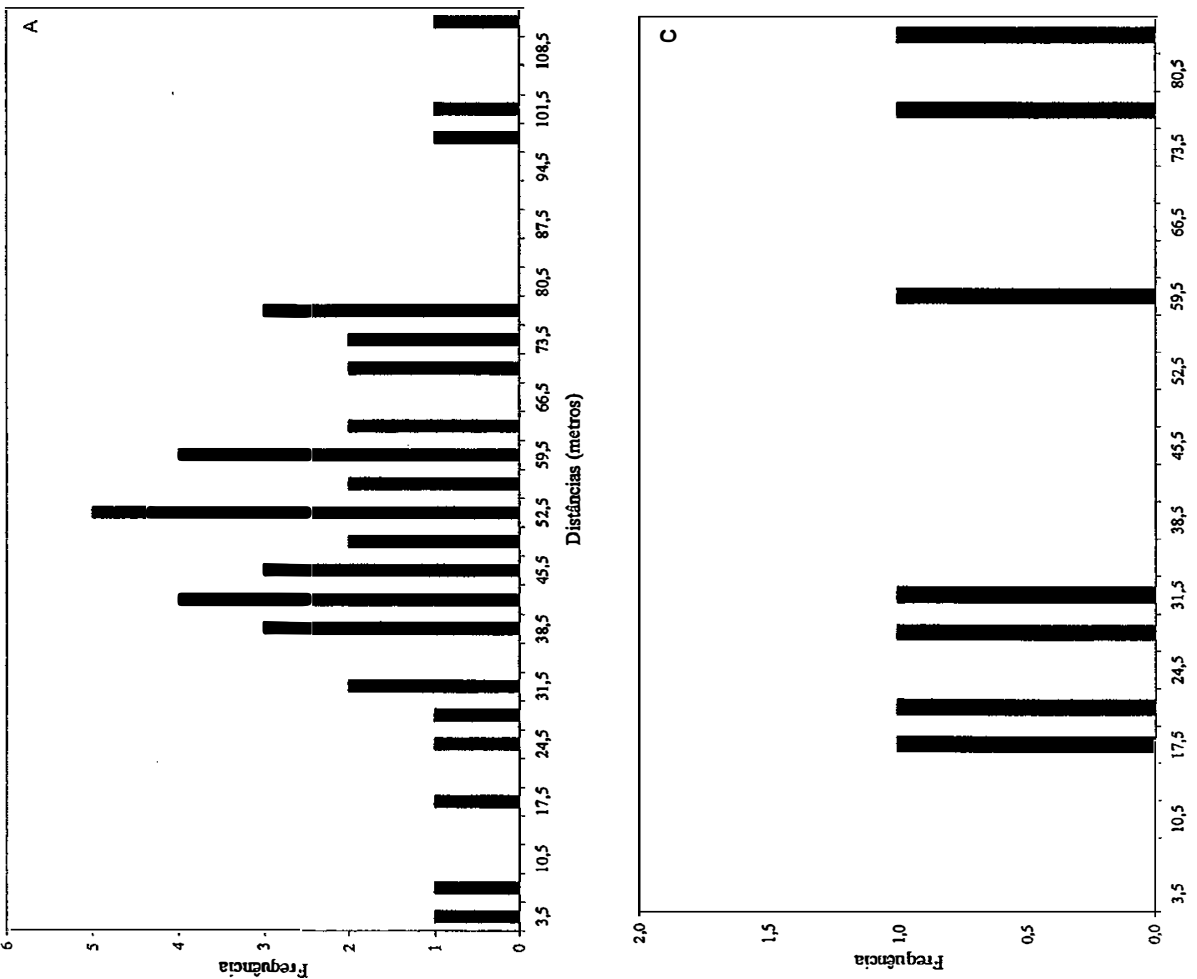

ส

염

可

옹

吾

矛

음 홍

준

x

응

รี ส

总

:

密 豞

:马

으 음

ส

过

:

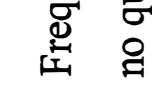

1

$\infty$

莺 
menos pronunciado (valores de $\mathrm{Z}$ mais elevados), e menores freqüências ocorreram numa larga faixa de classes de distância tanto no terceiro quanto no quarto fluxos vegetativos. Por outro lado, os talhões 8 e 25 , com os padrões de agregação mais fortes, foram os que apresentaram as maiores freqüências, ocorridas a classes de distância de até sessenta metros (Figuras 6 e 7).

\subsubsection{Análises dos gradientes de doença}

Dentre os modelos de gradiente de doença avaliados, o modelo Potência inversa foi o que melhor se ajustou aos dados de incidência de plantas doentes, embora tenham ocorrido ajustes adequados também para o modelo Exponencial negativo (Tabelas 7 e 8). Por outro lado, o modelo de Gompertz mostrou-se adequado aos dados de incidência apenas para o talhão 6/fluxo 4, o mesmo tendo ocorrido para os outros dois modelos ajustados a estes dados. Apesar de coeficientes de determinação relativamente altos terem sido obtidos com o ajuste dos modelos aos dados de incidência de folhas doentes, as distribuições de resíduos observadas foram inaceitáveis e adequados ajustes ocorreram somente aos dados do quarto fluxo vegetativo dos talhões 4, 5 e 6 (Tabelas 9 e 10). $O$ incremento da doença do terceiro para o quarto fluxo vegetativo resultou em gradientes mais suaves e menores coeficientes angulares $(b)$, em razão de maiores incrementos ocorridos a maiores distâncias do foco primário (Tabelas 7 e 8 e Figura 9).

Plantas doentes mais distantes do foco inicial também foram observadas no último fluxo vegetativo.

\subsubsection{Determinação de áreas isópatas}

Em todos os talhões estudados a doença teve seu início em plantas localizadas nas bordas dos talhões. Este fato pode ser visualizado nos mapas de linhas isópatas confeccionados a partir dos dados de incidência de plantas doentes (Figuras 10 a 14). Os dois únicos talhões que apresentaram crescimentos na incidência de plantas doentes do primeiro para o segundo fluxo vegetativo (22 e 25 ) 'estão apresentados na Figura 10, o 
Tabela 7 - Parâmetros de regressão dos modelos Exponencial negativo, Potência inversa e Gompertz ajustados aos dados da incidência de plantas com cancro cítrico no terceiro fluxo vegetativo e tendo-se considerado como plantas focos as preexistentes no mesmo talhão. Estado de São Paulo, Brasil

\begin{tabular}{|c|c|c|c|c|c|c|c|}
\hline Talhões & Modelos $^{\mathrm{a}}$ & $a$ & e.p. & $b$ & e.p. & $R^{2}$ & Resíduo \\
\hline \multirow[t]{3}{*}{2} & Exponencial negativo & 0,1289 & 0,0171 & 0,0321 & 0,0054 & 0,92 & - \\
\hline & Potência inversa & 0,9757 & 0,0842 & $-0,9226$ & 0,0292 & 1,00 & + \\
\hline & Gompertz & $-0,1838$ & 0,0693 & $-0,2789$ & 0,0191 & 0,98 & - \\
\hline \multirow[t]{3}{*}{8} & Exponencial negativo & 0,7605 & 0,0606 & 0,0564 & 0,0073 & 0,93 & + \\
\hline & Potência inversa & 1,4361 & 0,1961 & $-0,5783$ & 0,0646 & 0,93 & + \\
\hline & Gompertz & 1,6634 & 0,1529 & $-0,6620$ & 0,0564 & 0,95 & - \\
\hline \multirow[t]{3}{*}{22} & Exponencial negativo & 1,3078 & 0,2653 & 0,1666 & 0,0348 & 0,89 & - \\
\hline & Potência inversa & 3,2341 & 0,8392 & $-1,1494$ & 0,1583 & 0,92 & + \\
\hline & Gompertz & 2,0396 & 0,4069 & $-0,9495$ & 0,1490 & 0,85 & - \\
\hline \multirow[t]{3}{*}{25} & Exponencial negativo & 0,7304 & 0,1426 & 0,1114 & 0,0184 & 0,88 & + \\
\hline & Potência inversa & 4,3156 & 1,3736 & $-1,2900$ & 0,1416 & 0,94 & + \\
\hline & Gompertz & 1,1951 & 0,3057 & $-0,6853$ & 0,1153 & 0,86 & - \\
\hline
\end{tabular}

${ }^{a}$ Os modelos Exponencial negativo e Potência inversa foram ajustados por regressão não linear e o modelo de Gompertz por regressão linear dos dados de incidência de plantas transformados ($\ln (-\ln (y)))$ em função do $\ln$ da distância (x). 
Tabela 8 - Parâmetros de regressão dos modelos Exponencial negativo, Potência inversa e Gompertz ajustados aos dados da incidência de plantas com cancro cítrico no quarto fluxo vegetativo e tendo-se considerado como plantas focos as preexistentes no mesmo talhão. Estado de São Paulo, Brasil

\begin{tabular}{|c|c|c|c|c|c|c|c|}
\hline Talhões & Modelos $^{\mathrm{a}}$ & $a$ & e.p. & $b$ & e.p. & $R^{2}$ & Resíduo \\
\hline \multirow[t]{3}{*}{2} & Exponencial negativo & 0,1245 & 0,0065 & 0,0136 & 0,0012 & 0,43 & + \\
\hline & Potência inversa & 0,4780 & 0,0479 & $-0,5376$ & 0,0290 & 0,61 & + \\
\hline & Gompertz & $-0,3601$ & 0,0518 & $-0,1734$ & 0,0133 & 0,52 & - \\
\hline \multirow[t]{3}{*}{4} & Exponencial negativo & 0,7540 & 0,0582 & 0,0792 & 0,0073 & 0,84 & - \\
\hline & Potência inversa & 2,3924 & 0,1076 & $-1,0231$ & 0,0232 & 0,98 & + \\
\hline & Gompertz & 0,8630 & 0,1760 & $-0,5006$ & 0,0455 & 0,75 & - \\
\hline \multirow[t]{3}{*}{5} & Exponencial negativo & 0,4321 & 0,0336 & 0,0531 & 0,0071 & 0,99 & + \\
\hline & Potência inversa & 3,5154 & 0,2693 & $-1,2198$ & 0,0359 & 1,00 & + \\
\hline & Gompertz & 0,7547 & 0,1871 & $-0,4962$ & 0,0485 & 0,97 & - \\
\hline \multirow[t]{3}{*}{6} & Exponencial negativo & 0,0757 & 0,0081 & 0,0201 & 0,0034 & 0,92 & + \\
\hline & Potência inversa & 0,4574 & 0,2148 & $-0,7339$ & 0,1449 & 0,88 & + \\
\hline & Gompertz & $-0,3880$ & 0,0965 & $-0,2337$ & 0,0263 & 0,94 & + \\
\hline \multirow[t]{3}{*}{8} & Exponencial negativo & 0,9893 & 0,0187 & 0,0252 & 0,0010 & 0,96 & + \\
\hline & Potência inversa & 1,6977 & 0,1313 & $-0,3739$ & 0,0288 & 0,80 & - \\
\hline & Gompertz & 3,3724 & 0,1125 & $-0,9129$ & 0,0366 & 0,94 & - \\
\hline \multirow[t]{3}{*}{20} & Exponencial negativo & 1,5498 & 0,1473 & 0,1354 & 0,0155 & 0,98 & - \\
\hline & Potência inversa & 3,4496 & 0,2472 & $-0,9871$ & 0,0443 & 0,99 & + \\
\hline & Gompertz & 1,4033 & 0,0925 & $-0,6120$ & 0,0243 & 0,99 & - \\
\hline \multirow[t]{3}{*}{22} & Exponencial negativo & 0,8466 & 0,0443 & 0,0501 & 0,0034 & 0,80 & - \\
\hline & Potência inversa & 2,0229 & 0,1983 & $-0,6681$ & 0,0402 & 0,76 & - \\
\hline & Gompertz & 2,0137 & 0,1242 & $-0,7293$ & 0,0382 & 0,82 & - \\
\hline \multirow[t]{3}{*}{25} & Exponencial negativo & 0,8116 & 0,0282 & 0,0285 & 0,0016 & 0,86 & - \\
\hline & Potência inversa & 2,0639 & 0,1497 & $-0,5496$ & 0,0257 & 0,83 & - \\
\hline & Gompertz & 2,4354 & 0,1082 & $-0,7331$ & 0,0309 & 0,85 & - \\
\hline
\end{tabular}

${ }^{\mathrm{a}}$ Os modelos Exponencial negativo e Potência inversa foram ajustados por regressão não linear e o modelo de Gompertz por regressão linear dos dados de incidência de plantas transformados ($\ln (-\ln (y)))$ em função do $\ln$ da distância $(x)$. 
Tabela 9 - Parâmetros de regressão não linear dos modelos Exponencial negativo e Potência inversa ajustados aos dados da incidência de folhas/planta com cancro cítrico no terceiro fluxo vegetativo e tendo-se considerado como plantas focos as preexistentes no mesmo talhão. Estado de São Paulo, Brasil

\begin{tabular}{|c|c|c|c|c|c|c|c|}
\hline Talhões & Modelos & $a$ & e.p. & $b$ & e.p. & $R^{2}$ & Resíduo \\
\hline \multirow[t]{2}{*}{2} & Exponencial negativo & 0,6072 & 0,1266 & 0,0466 & 0,0103 & 0,90 & - \\
\hline & Potência inversa & 7,4700 & 2,0634 & $-1,1896$ & 0,0974 & 0,98 & - \\
\hline \multirow[t]{2}{*}{8} & Exponencial negativo & 4,1934 & 0,3215 & 0,0865 & 0,0087 & 0,96 & - \\
\hline & Potência inversa & 9,0253 & 0,6897 & $-0,7745$ & 0,0396 & 0,98 & - \\
\hline \multirow[t]{2}{*}{22} & Exponencial negativo & 4,8136 & 1,0218 & 0,1635 & 0,0360 & 0,89 & - \\
\hline & Potência inversa & 11,9126 & 3,6510 & $-1,1431$ & 0,1865 & 0,89 & - \\
\hline \multirow[t]{2}{*}{25} & Exponencial negativo & 5,3398 & 1,8335 & 0,1831 & 0,0391 & 0,86 & - \\
\hline & Potência inversa & 70,0826 & 47,8388 & $-1,9652$ & 0,3237 & 0,90 & - \\
\hline
\end{tabular}


Tabela 10 - Parâmetros de regressão não linear dos modelos Exponencial negativo e Potência inversa ajustados aos dados da incidência de folhas/planta com cancro cítrico no quarto fluxo vegetativo e tendo-se considerado como plantas focos as preexistentes no mesmo talhão. Estado de São Paulo, Brasil

\begin{tabular}{|c|c|c|c|c|c|c|c|}
\hline Talhões & Modelos & $a$ & e.p. & $b$ & e.p. & $R^{2}$ & Resíduo \\
\hline \multirow[t]{2}{*}{2} & Exponencial negativo & 0,3970 & 0,0297 & 0,0233 & 0,0021 & 0,43 & - \\
\hline & Potência inversa & 2,1047 & 0,3243 & $-0,7371$ & 0,0474 & 0,54 & - \\
\hline \multirow[t]{2}{*}{4} & Exponencial negativo & 0,8978 & 0,0618 & 0,0716 & 0,0056 & 0,87 & + \\
\hline & Potência inversa & 2,4637 & 0,2796 & $-0,9388$ & 0,0538 & 0,86 & + \\
\hline \multirow[t]{2}{*}{5} & Exponencial negativo & 1,8834 & 0,1117 & 0,0639 & 0,0064 & 1,00 & + \\
\hline & Potência inversa & 22,1186 & 0,6234 & $-1,4300$ & 0,0135 & 1,00 & + \\
\hline \multirow[t]{2}{*}{6} & Exponencial negativo & 0,2284 & 0,0345 & 0,0306 & 0,0058 & 0,93 & + \\
\hline & Potência inversa & 3,1854 & 0,9133 & $-1,0807$ & 0,0917 & 0,98 & + \\
\hline \multirow[t]{2}{*}{8} & Exponencial negativo & 3,2595 & 0,1168 & 0,0392 & 0,0022 & 0,92 & - \\
\hline & Potência inversa & 6,4253 & 0,6018 & $-0,5133$ & 0,0370 & 0,82 & - \\
\hline \multirow[t]{2}{*}{20} & Exponencial negativo & 4,3589 & 0,3390 & 0,1652 & 0,0142 & 0,99 & - \\
\hline & Potência inversa & 10,3172 & 0,5010 & $-1,1299$ & 0,0317 & 1,00 & + \\
\hline \multirow[t]{2}{*}{22} & Exponencial negativo & 1,7940 & 0,1288 & 0,0700 & 0,0060 & 0,75 & - \\
\hline & Potência inversa & 4,9179 & 0,5505 & $-0,8285$ & 0,0502 & 0,76 & - \\
\hline \multirow[t]{2}{*}{25} & Exponencial negativo & 1,7627 & 0,1100 & 0,0321 & 0,0029 & 0,68 & - \\
\hline & Potência inversa & 4,8054 & 0,5546 & $-0,5992$ & 0,0419 & 0,68 & - \\
\hline
\end{tabular}

${ }^{a}$ Os modelos foram ajustados por regressão não linear dos dados de incidência de folhas (classes de notas) e a distância (metros). 

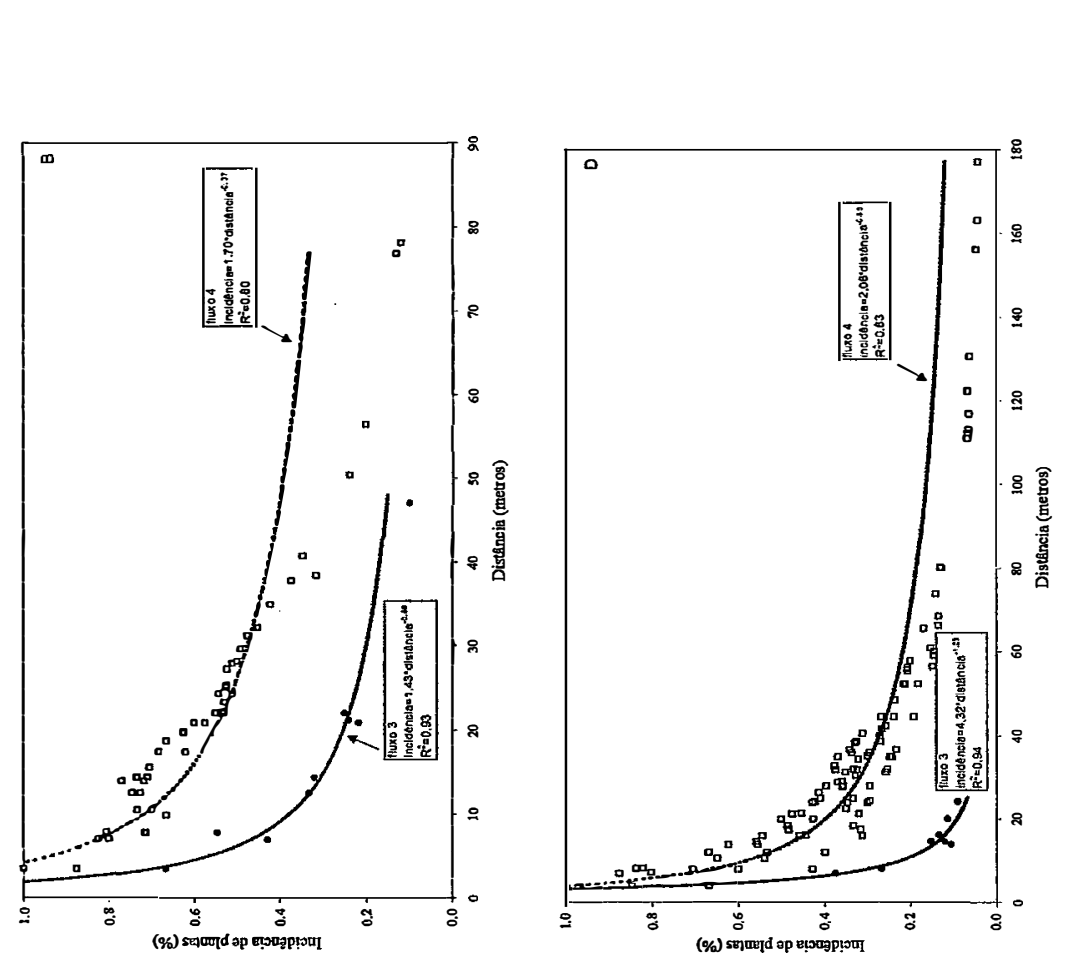

ㅇํㅇ \&

胥 壱 N

䒕 总

. 해 $\infty$

窎

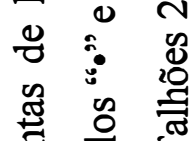

苞 응 ज

ه 章 总

ช 0

过 :

兽 要

.

议

. 丞 总

.
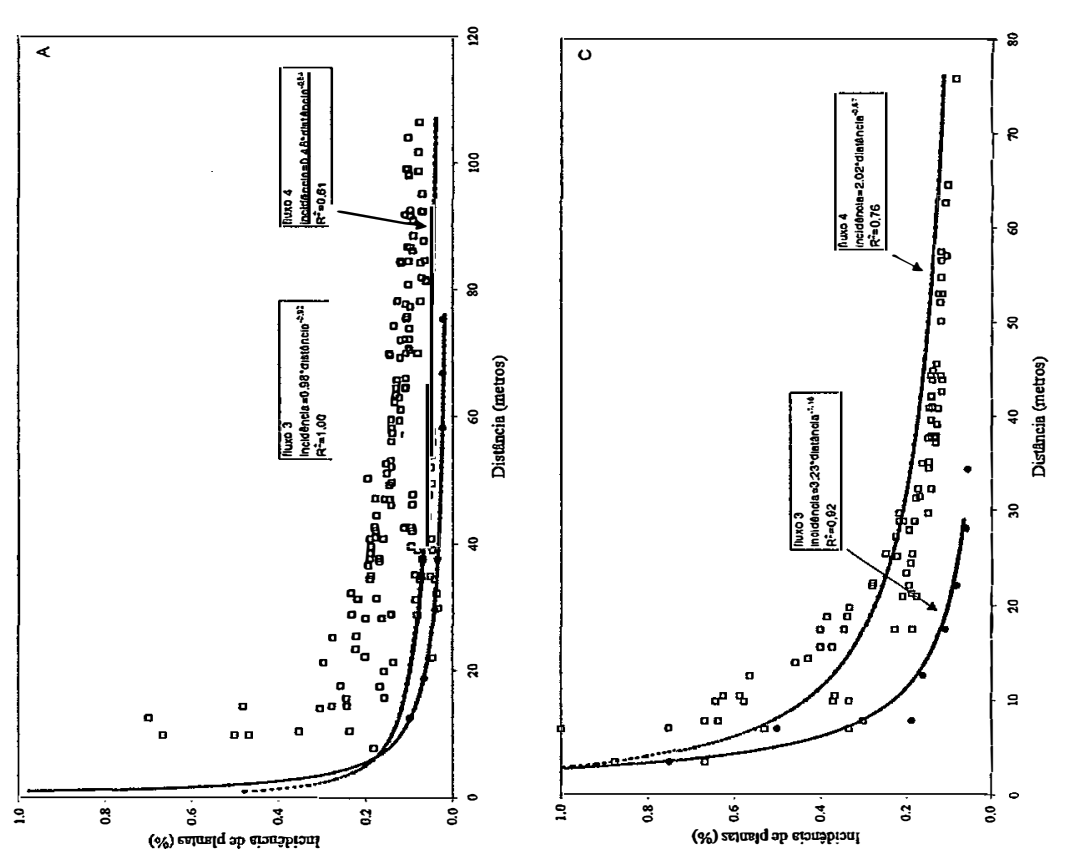

으 0 늘 


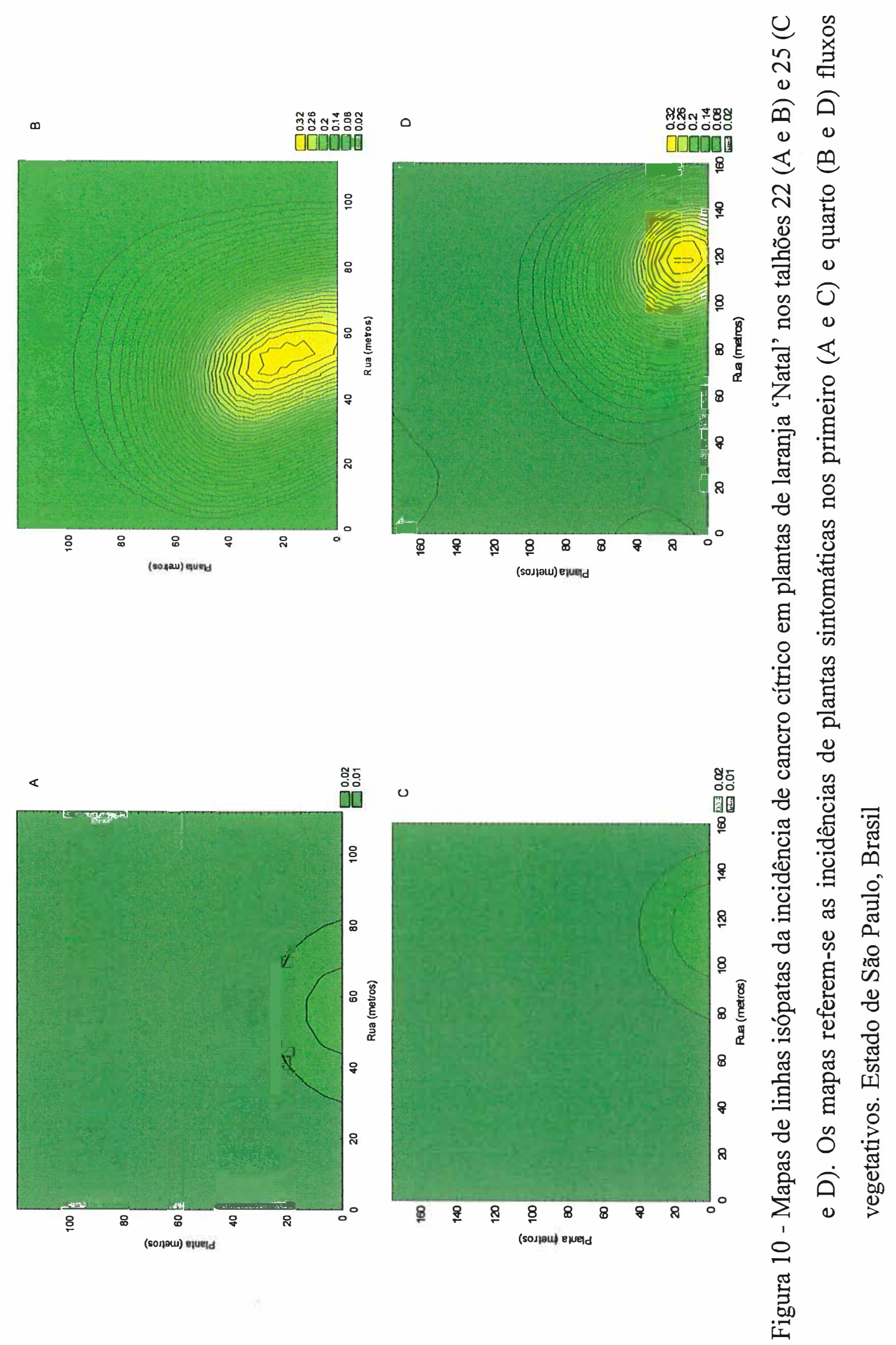




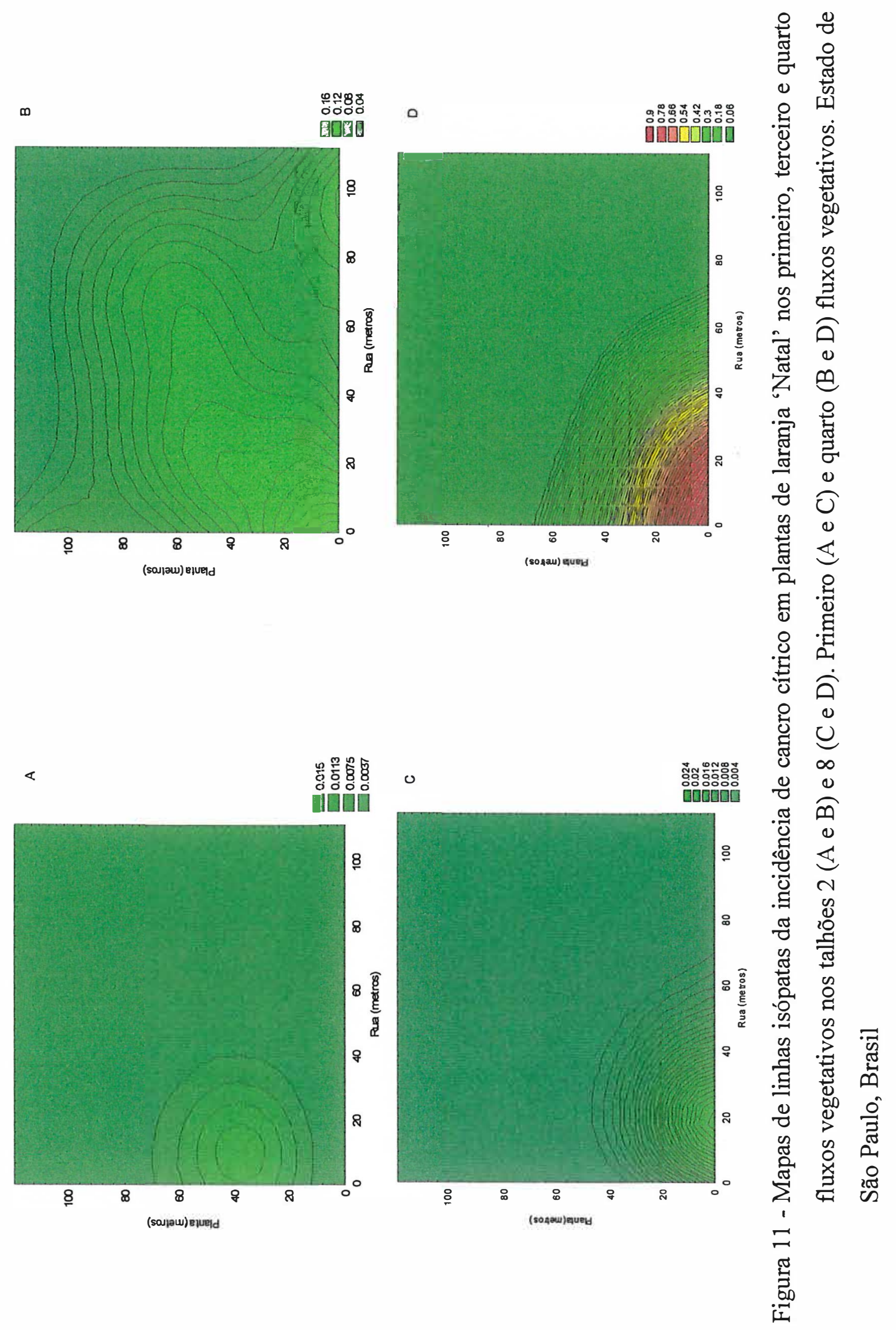




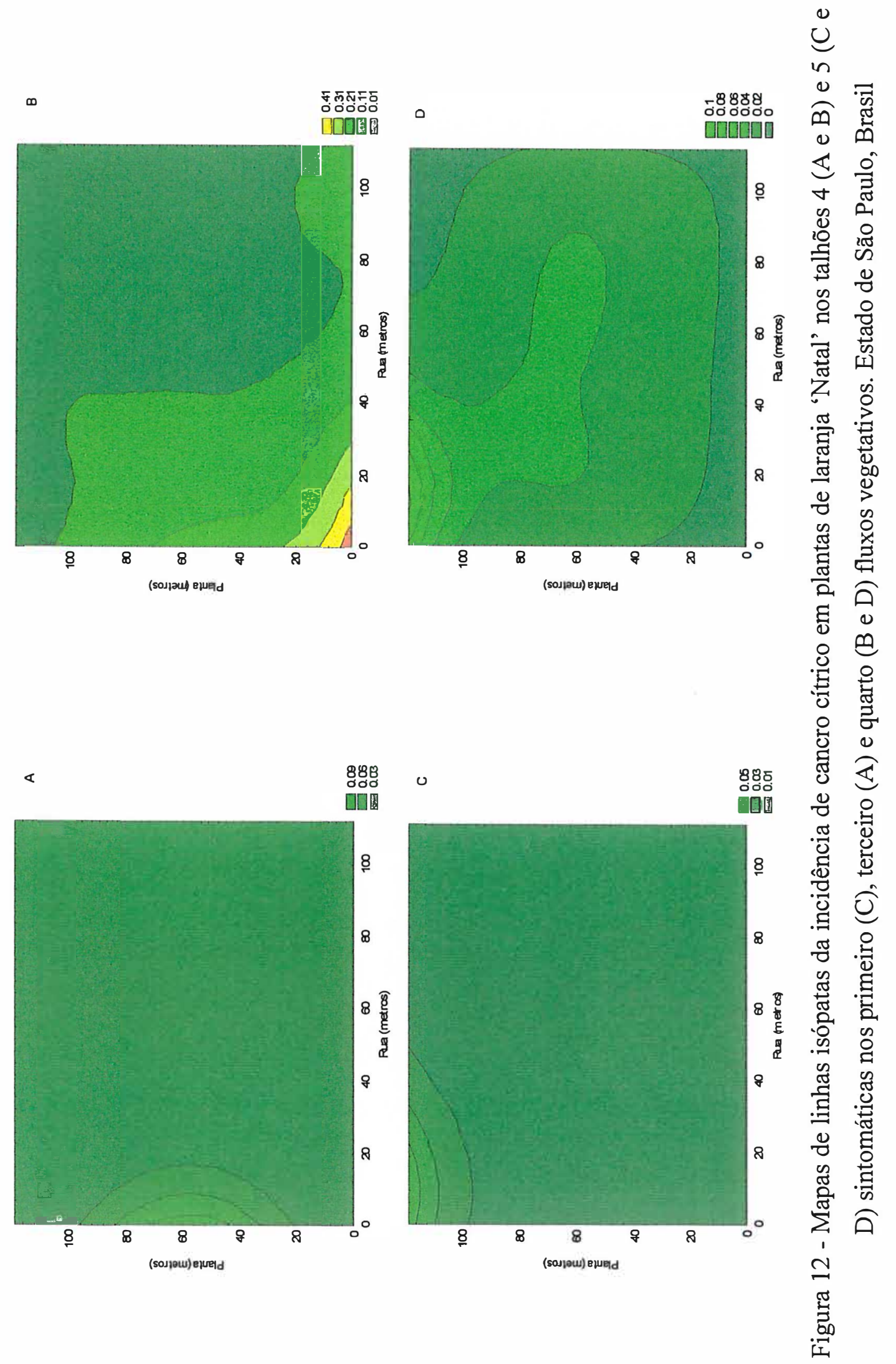



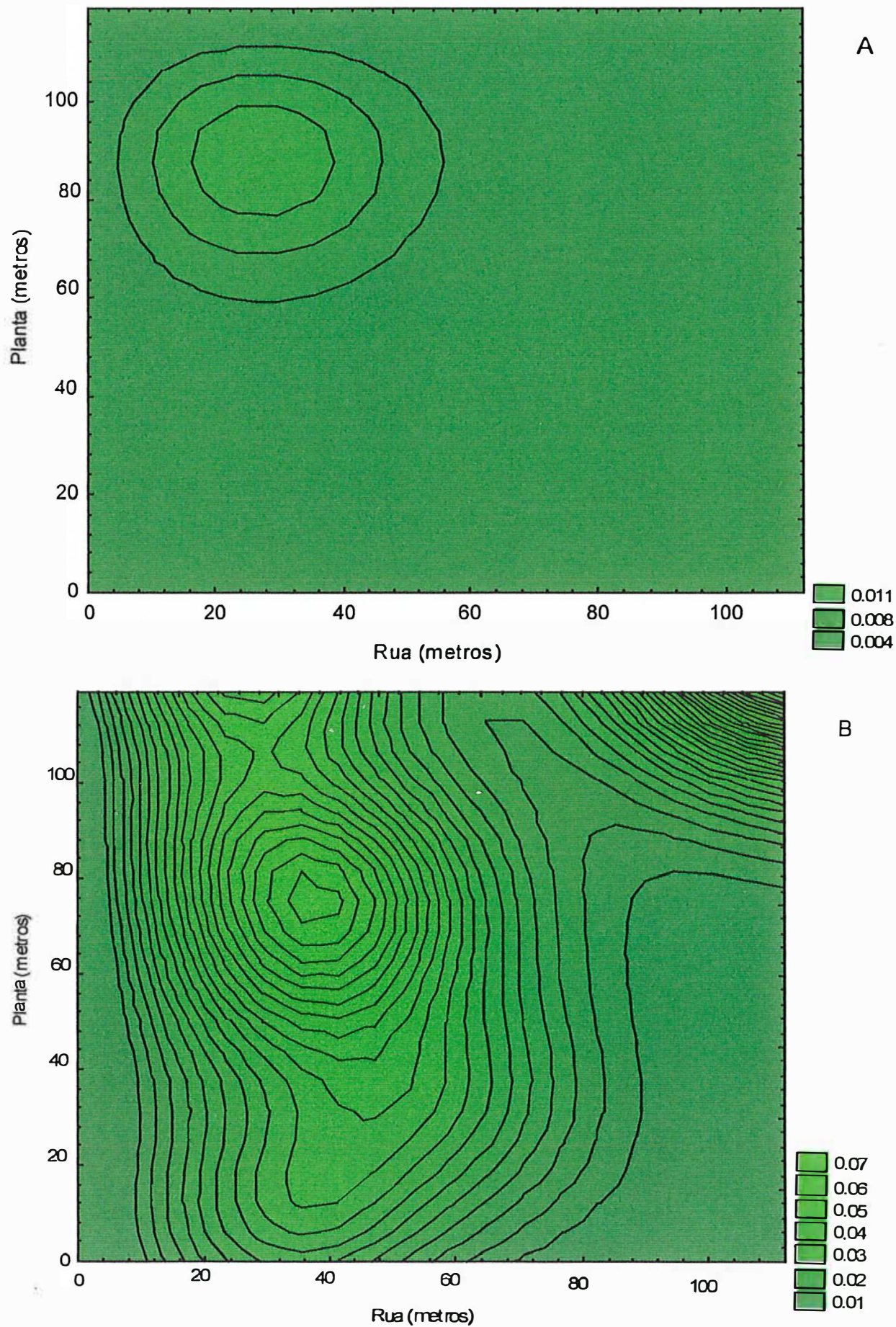

Figura 13 - Mapas de linhas isópatas da incidência de cancro cítrico em plantas de laranja 'Natal' no talhão 6 sintomáticas nos terceiro (A) e quarto (B) fluxos vegetativos. Estado de São Paulo, Brasil 

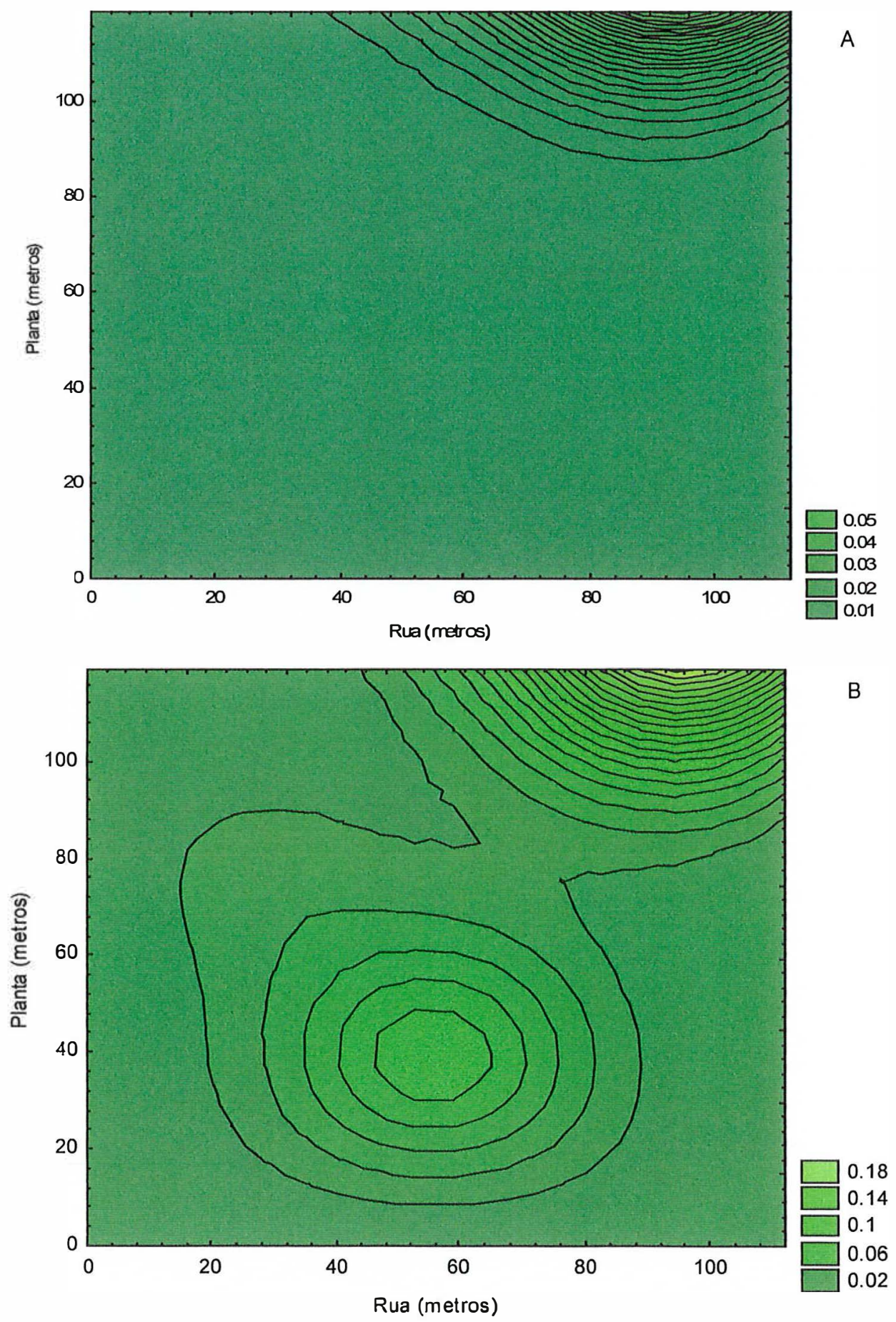

Figura 14 - Mapas de linhas isópatas da incidência de cancro cítrico em plantas de laranja 'Natal' no talhão 20 sintomáticas nos terceiro (A) e quarto (B) fluxos vegetativos. Estado de São Paulo, Brasil 
que permite a comparação da localização, intensidade e da forma do foco ao longo do tempo. Os incrementos na incidência de plantas ocorreram radialmente a partir da(s) planta(s) foco, sem que tenha ocorrido uma direção predominante. $O$ talhão 22 apresentou padrões de agregação de plantas doentes similares nas linhas e entre linhas de plantas, com valores de $\mathrm{Z}$ de - 5,08 e - 3,52, respectivamente. Este padrão de agregação pode ser visualizado na Figura 10. O crescimento do foco ocorreu, de maneira geral, na mesma proporção tanto nas linhas de plantio, quanto entre linhas. Por outro lado, o talhão 25 foi o único com maior agregação entre linhas de plantas nos segundo e terceiro fluxos vegetativos (valores de $\mathrm{Z}$ iguais a - 53,23 e - 20,32, respectivamente). De fato, os mapas que representam a incidência de plantas doentes neste talhão ilustram claramente o crescimento da doença mais pronunciado entre as linhas de plantas.

Nos terceiro e quarto fluxos vegetativos foi identificado o surgimento de novos focos, distantes do foco inicial, em quase todos os talhões estudados. Um dos exemplos é o talhão 2, representado na Figura 11. O reflexo do surgimento de novos focos pode ser visualizado na Figura 11B, na qual observa-se o aparecimento de largas áreas isópatas e um extenso crescimento do foco inicial. Em contraste, representado na mesma figura, pode-se visualizar o talhão 8 , com incidência máxima de plantas de $0,90 \%$, maior que a máxima observada no talhão $2(0,16 \%)$, localizada no centro do foco, o qual compreendia uma extensão de aproximadamente setenta metros. Outros três exemplos do surgimento de novos focos estão apresentados nas Figura 12 a 14. Nestes talhões, as incidências máximas, calculadas em relação às distâncias entre plantas doentes, também foram menores que as ocorridas em talhões sem a presença de novos focos pronunciados ou distantes do foco inicial. Como exemplo, os talhões 2, 5, 6, e 20 apresentaram como incidência máxima os valores 0,$16 ; 0,10 ; 0,07$ e 0,18\%, respectivamente (Figuras 11 a 14). Comparativamente, nos talhões 8,22 e 25 , com maiores agregações de plantas doentes, as máximas incidências foram de 0,90;0,32 e 0,32\%, respectivamente (Figuras 10 e 11).

\subsection{Discussão}


O plantio das mudas nos talhões 25 e 26 ocorreu durante o mês de dezembro de 2002 e nos demais talhões (1 a 24) no mês de janeiro de 2003. A temperatura ideal para ocorrência de infeç̧ão por Xac varia de 20 a $30^{\circ} \mathrm{C}$, com ótimo ao redor de $28^{\circ} \mathrm{C}$ (Koizumi, 1977). A disseminação da bactéria dá-se, principalmente, por respingos de chuvas e de chuvas associadas a ventos, especialmente quando a velocidade do vento supera $8 \mathrm{~m} / \mathrm{s}$ (Gottwald et al., 1988; Gottwald et al., 1989). Considerando as temperaturas mínima e máxima e as precipitações ocorridas na região durante o período compreendido entre o início do plantio dos talhões e as avaliações, estima-se que as plantas doentes com sintomas no primeiro fluxo vegetativo foram infectadas até fevereiro de 2003, ou seja, logo após o plantio, e as plantas sintomáticas no segundo fluxo vegetativo foram infectadas algumas semanas após. Ocorreram temperaturas mínimas superiores a $20^{\circ} \mathrm{C}$ e máximas próximas a $30^{\circ} \mathrm{C}$ até cerca de 150 dias do início do plantio (final de abril), e precipitações sucessivas, da ordem de 68,5;371,0;135,8; 136,9; e 79,0 mm, de dezembro a abril, respectivamente (Figura 15). A suscetibilidade de folhas cítricas à infeç̧ão por Xac é máxima até a segunda metade da fase de expansão vegetativa (Gottwald \& Graham, 1992; Stall et al., 1982). Tecidos com ferimentos, como os provocados pelo minador dos citros, apresentam-se suscetíveis por mais tempo (Chagas et al., 2001). Em razão das precipitações ocorridas até 150 dias após o início do plantio e dos tratos culturais efetuados pelo produtor durante este período, como fertilizações, o segundo fluxo vegetativo deve ter sido emitido entre março e abril de 2003, período este no qual ocorreram novas infecções por Xac. Apesar de não existirem dados disponíveis a respeito da velocidade do vento, considera-se que neste período, por vários dias, ocorreram condições favoráveis à disseminação e à infecção por Xac.

Os meses de maio a agosto de 2003 (dos 152 aos 274 dias após o início do plantio) foram caracterizados por temperaturas mínimas inferiores a $20^{\circ} \mathrm{C}$ e precipitações esporádicas, que totalizaram $75,2 \mathrm{~mm}$, não tendo ocorrido condições favoráveis a emissão de novos fluxos vegetativos pelo hospedeiro e também da disseminação/infecção pelo patógeno. Com o reinício do período com temperaturas mínimas superiores a $20^{\circ} \mathrm{C}$, a partir de setembro de 2003 (304 dias), e de precipitações 


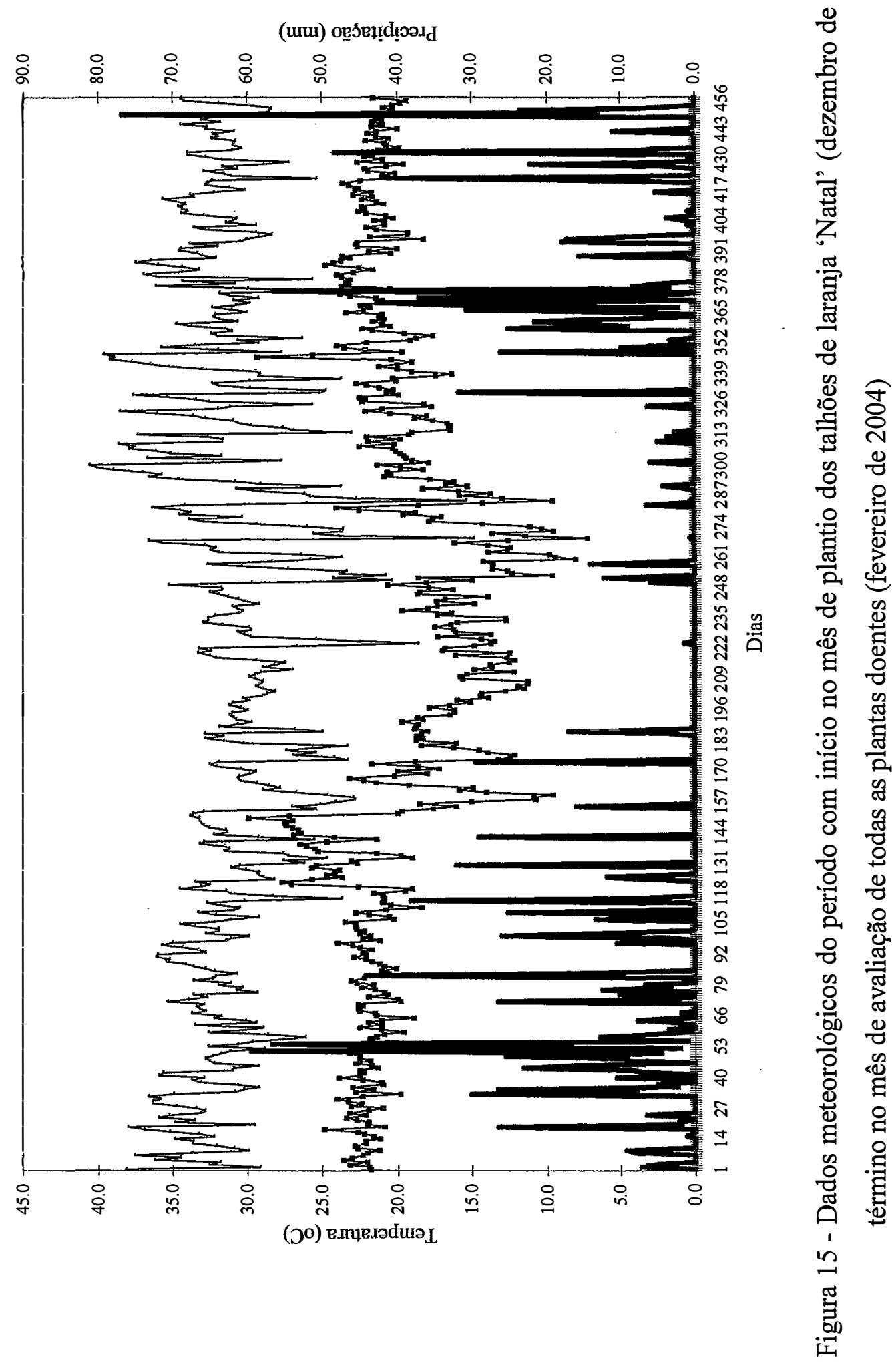


periódicas, a emissão do terceiro fluxo vegetativo deve ter ocorrido entre os meses de setembro e outubro de 2003 (entre os 275 e 335 dias), e a emissão do quarto fluxo vegetativo entre novembro e dezembro (dos 336 aos 396 dias). Nestes dois fluxos, as infecções provavelmente ocorreram nos meses de outubro/novembro (305 a 365 dias) e dezembro/janeiro (366 a 427 dias), respectivamente, em razão das maiores temperaturas mínima e máxima observadas, precipitações constantes e em muitos dias superiores a 20 $\mathrm{mm}$, e presença de brotações novas. Na maioria das plantas dos talhões avaliados observou-se a presença de danos provocados pelo minador dos citros, principalmente nas folhas do quarto fluxo vegetativo, o que contribuiu no incremento da doença neste período.

Nos talhões 1 e 3,15 e $22 \%$, respectivamente, das plantas doentes foram avaliadas quanto aos fluxos vegetativos sintomáticos. No talhão $1,5 \%$ das plantas doentes apresentavam sintomas no segundo fluxo vegetativo, enquanto no talhão 3 , $8,27 \%$ das plantas doentes apresentavam sintomas no primeiro fluxo vegetativo. $\mathrm{Na}$ amostragem realizada, não foram encontradas plantas doentes com sintomas no primeiro fluxo vegetativo do talhão 1 . Em qualquer outro talhão avaliado não foram encontradas incidências iniciais desta magnitude e o maior número de plantas inicialmente infectadas nos talhões 1 e 3 foi o fator preponderante que resultou nas incidências finais de $30 \mathrm{e}$ $70 \%$ de plantas doentes. Considerando os talhões nos quais todas as plantas foram avaliadas quanto aos fluxos vegetativos sintomáticos (exclui-se os talhões 1 e 3), o número de plantas doentes variou de uma a 49 e as incidências de 0,17 a 8,24\%, respectivamente. Comparativamente, incidências superiores a 40 e $80 \%$ foram observadas em condições experimentais na Argentina após 230 e 350 dias, respectivamente, da inoculação da planta central de cada parcela experimental (Gottwald et al., 1988; Gottwald et al., 1989).

Apesar da uniformidade entre os talhões no que refere-se a idade, localização geográfica, tratos culturais e espécie vegetal/variedade, foram observadas incidências que variaram de menos que um a mais que $70 \%$ de plantas doentes, incidências essas atingidas após doze/quatorze meses do início da epidemia. A avaliação das plantas quanto à localização da doença em diferentes fluxos vegetativos permitiu a identificação 
das plantas e dos talhões inicialmente infectados. Incidências finais maiores foram observadas nos talhões infectados no primeiro fluxo vegetativo, logo após o plantio (talhões 2, 3, 8, 22 e 25). O número de plantas doentes infectadas neste primeiro fluxo influenciou diretamente a incidência final da doença no talhão. Um pequeno incremento da doença ocorreu quando as plantas encontravam-se no segundo fluxo vegetativo, em razão das menores temperaturas e, principalmente, do menor número de precipitações ocorridas neste período. Claramente, o incremento da doença esteve diretamente relacionado às condições meteorológicas propícias à disseminação/infecção pelo patógeno e o crescimento do hospedeiro (Gottwald et al., 1988; Gottwald et al., 1989; Gottwald et al., 1992b; Koizumi, 1977; Stall et al., 1982).

A agregação das plantas doentes foi maior ao longo das linhas, embora tenha ocorrido também entre linhas de plantas, como observado em estudos anteriores (Gottwald et al., 1988; Gottwald et al., 1989). A maior agregação nas linhas ocorre em razão da maior proximidade das plantas, em comparação com a maior distância entre linhas. Gottwald et al. (1988), usando a metodologia de análise de seqüências ordinárias, observaram padrões mais agregados no início da epidemia, antes do aparecimento de focos secundários, o que reduziu o padrão de agregação de plantas doentes. Neste estudo os valores de $\mathrm{Z}$ observados variaram de - 2,14 a - 7,10 até os 220 dias após infecção da planta foco. Estes autores também observaram padrão de agregação maior nas linhas de plantas do que entre linhas, embora padrões agregados tenham sido observados nas duas direções. Padrões mais agregados quando na menor distância entre plantas indica o efeito da disseminação do patógeno por respingos de chuvas (Gottwald et al., 1995). Padrões de agregação mais fortes (valores de $\mathrm{Z}$ mais negativos) foram observados nesses estudos anteriores, em comparação com os resultados aqui apresentados (Gottwald et al., 1988; Gottwald et al., 1989). Padrões menos agregados da doença passaram a ser mais freqüentes após a introdução da larva minadora no Brasil (Bergamin Filho et al., 2000), o que explicaria os maiores valores observados de Z. A presença de inúmeras plantas com danos do minador faz com que a disseminação da bactéria por chuvas com ventos e aerossóis seja mais eficiente na propagação da doença a longas distâncias. Este novo padrão é caracterizado não somente pela menor agregação de plantas doentes, mas 
também pela maior freqüência de plantas doentes mais distantes do foco inicial, o que proporciona gradientes de doença mais suaves, como também observado (Tabelas 7 e 8 e Figura 9). $O$ fato do modelo Potência inversa ter sido o que melhor ajustou-se aos dados de incidência também está de acordo com este novo padrão espacial, uma vez que este modelo pressupõe maiores proporções de doença a distâncias mais longas do foco inicial (Minogue, 1989).

Análises da distribuição espacial do cancro cítrico revelaram gradientes de doença mais abruptos no início da epidemia, em razão da maior concentração de plantas doentes a distâncias mais curtas do foco inicial (Gottwald et al., 1988). Coeficientes angulares da regressão linear entre a incidência transformada de doença (Gompit) e o $\log _{10}$ da distância do foco inicial, obtidos em estudos anterioes, variaram de - 0,21 a 4,13 (Danós et al., 1984). Em outro estudo foram observados gradientes menos abruptos (valores de $b$ de - 1,86 a $+0,05$ ), que variaram para diferentes hospedeiros e ao longo do tempo, como resultado da desfolha provocada pela doença. Os coeficientes angulares observados também variaram em razão da direção a partir do foco inicial, tendo sido maiores na direção predominante do vento (Gottwald et al., 1988). Os coeficientes angulares, aqui apresentados, obtidos com a transformação dos dados (Gompit) do terceiro fluxo vegetativo variaram de - 0,28 a - 0,95 e do quarto fluxo de - 0,17 a - 0,91, menores que os obtidos por Gottwald et al. (1988). Gottwald et al. (1989) também observaram quedas nos valores de $b$ com o incremento da doença, os quais variaram entre - 2,0 e - 1,0, até aproximadamente cinquenta dias após a inoculação, e - 0,50 e 0,25 entre 250 e 350 dias após. Os modelos utilizados não foram ajustados adequadamente aos dados de incidência de plantas ou de folhas/plantas dos talhões $22 \mathrm{e}$ 25 , isto tendo ocorrido em razão do surgimento de novos focos, formando áreas maiores e irregulares, de difícil quantificação por modelos de gradiente de doença (Gottwald et al., 1992b).

$\mathrm{O}$ incremento da doença foi caracterizado tanto pelo aumento do NMPF quanto pelo aumento do NFU, muitas vezes localizados a maiores distâncias dos focos iniciais. A disseminação por respingos de chuva implica na propagação da doença entre plantas vizinhas (Gottwald et al., 1995; Gottwald et al., 1997a). Por outro lado, chuvas 
associadas com ventos são capazes de dispersar o inóculo a curtas e longas distâncias. Estes dois mecanismos podem atuar conjuntamente na disseminação da bactéria causadora do cancro cítrico, resultando em plantas doentes a diferentes distâncias do foco inicial, distâncias essas que podem ser de dezenas de metros ou até mesmo quilômetros (Gottwald et al., 2002b). Aparentemente, esses dois mecanismos de disseminação ocorreram nos talhões avaliados. Apesar disso, foram observadas diferenças quanto à localização e intensidade dos focos (Figuras 10 a 14), o que está diretamente relacionado aos mecanismos de disseminação da bactéria e revela que estes atuaram de modo diferenciado entre os talhões. Infelizmente não há dados disponíveis, como por exemplo em relação à direção predominante do vento, intensidade dos danos da larva minadora, crescimento do hospedeiro, entre outros, que poderiam auxiliar na explicação destas diferenças.

A aplicação da legislação atual, válida em São Paulo, determinaria a erradicação de todos os talhões caso estes fossem detectados quando no quarto fluxo vegetativo, em razão de incidências de plantas doentes superiores a 0,5\%. As exceções seriam os talhões 15, 24 e 26, com incidências entre 0,17 e 0,18\%, e infectados no quarto fluxo vegetativo. Apesar disso, foram observadas distâncias máximas entre plantas doentes, de fluxos diferentes, muito superiores que trinta metros (até 177,16 m). Mesmo as distâncias médias foram, na maioria dos casos, superiores a esta distância (até 57,07 m). A adoção de um raio de erradicação pressupõe a eliminação das plantas foco e das demais suspeitas de infecção, dispostas ao redor da planta foco. As distâncias de disseminação da doença são o fator preponderante na definição da estratégia a ser adotada na erradicação do cancro cítrico (Gottwald et al., 2002b). Neste sentido, as distâncias determinadas no presente estudo mostraram que as plantas suspeitas de contaminação estão a distâncias maiores que trinta metros, uma vez que ocorreram plantas doentes; na comparação entre fluxos vegetativos, a distâncias até 177,16 m. Nos talhões $2,5,6,8,20$ e 22 foi observada uma única planta doente com sintomas nos segundos ou terceiros fluxos vegetativos (Tabela 1). No fluxo vegetativo seguinte o número de plantas aumentou para oito, seis, oito, quinze, dez e quatro, respectivamente, e as distâncias (raios) que englobariam 90\% das plantas doentes seriam de 75,39; 91,87; 
81,93; 22,14 e 91,00 e 21,00 m, respectivamente. Essas distâncias foram calculadas considerando-se todas as combinações possiveis entre plantas doentes de diferentes fluxos vegetativos, não tratando-se de distâncias de disseminação da bactéria, que teoricamente são maiores. Além disso, foi adotada como premissa que as plantas foco de cada talhão originaram as demais plantas doentes nesse mesmo talhão, o que pode não ter ocorrido e os focos terem sido plantas localizadas a maiores distâncias. $\mathrm{O}$ talhão 7 é um exemplo, o qual apresentou sete plantas doentes no quarto fluxo vegetativo, com distâncias mínima e máxima entre plantas de 3,50 e 148,82 metros, sem que tivessem ocorrido plantas contaminadas nesse talhão em fluxos anteriores. $O$ talhão doente mais próximo a este talhão estava a cinquenta metros de distância. Até mesmo a contaminação dos talhões que continham plantas com sintomas de cancro cítrico no primeiro fluxo vegetativo pode ter ocorrido em razão da preexistência de plantas doentes em propriedades vizinhas, localizadas no ano de 2003. Estas plantas estavam a distâncias próximas a 1,5 quilômetro da propriedade que serviu de base para o presente estudo. 


\section{DIVERSIDADE GENÉTICA DE Xanthomonas axonopodis PV. citri NO ESTADO DE SÃO PAULO}

\section{Resumo}

Uma adequada caracterização da estrutura genética da população de patógenos bacterianos tem sido feita, dentre outras técnicas, por Southern blot (restriction fragment length polymorphism-RFLP) empregando-se como sondas seqüências de inserção (insertion sequences-IS). Técnicas com boa reprodutibilidade, poder discriminatório e facilidade de uso poderiam ser usadas, por exemplo, na identificação da origem de focos de cancro cítrico. Neste sentido, o presente estudo objetivou a identificação e caracterização da diversidade genética de isolados de Xanthomonas axonopodis pv. citri, originários do Estado de São Paulo, empregando-se as técnicas de Southern blot (RFLP) e fluorescent amplified fragment length polymorphism (FAFLP). Um total de 30, 34 e 17 haplótipos foram identificados usando as sondas ISXacl, ISXac2 e ISXac3, respectivamente. Considerando-as conjuntamente, um total de 64 haplótipos foi identificado. As similaridades (Jaccard) mínima e média foram de 0,59 e 0,84 . Os resultados obtidos por RFLP permitiram uma relativa divisão dos isolados de acordo com a origem geográfica destes. A genotipagem dos isolados de Xac por FAFLP produziu resultados diferentes dos observados por RFLP. Com a combinação dos primers SacI + C e MspI + A, T, G e C apenas seis haplótipos foram identificados. As similaridades mínima e média observadas (Jaccard) variaram de 0,96 a 0,99 . Não houve uma correspondência entre os resultados obtidos com RFLP e FAFLP quanto aos haplótipos identificados. 


\section{Summary}

\section{Genetic Diversity of Xanthomonas axonopodis pv. citri in São Paulo State}

An adequate characterization of the genetic structure in populations of bacterial pathogens can be made, for example, by southern blot analysis (restriction fragment length polymorphism-RFLP) using insertion sequences (IS) as a DNA probe. Technics with a good reproducibility, discrimination, and easy to use could be employed in the identification of the origin of citrus canker foci. For this, the objective of this present work was to identify and characterize the genetic diversity of Xanthomonas axonopodis pv. citri in São Paulo State, using the RFLP and FAFLP (fluorescent amplified fragment length polymorphism) technics. A total of 30, 34, and 17 haplotypes were identified using the ISXac1, ISXac2 e ISXac3 probes, respectively. Considering the three probes a total of 64 haplotypes was identified. The minimum and average similarities (Jaccard) were 0.59 and 0.84 . A partial division of the isolates by the geographic origin were possible with the RFLP technique. Results of FAFLP were different from those obtained by RFLP. With the primers $S a c I+C$ and $M s p I+A, T, G$, and C only six haplotypes were identified. The minimum and average similarities (Jaccard) were 0.96 and 0.99 . There was no relationship between the RFLP and FAFLP results considering the haplotypes identified.

\subsection{Introdução}

Xanthomonas axonopodis pv. citri (Xac) é uma bactéria gram negativa, aeróbia, de formato tipo bastonete com um flagelo polar, capaz de induzir sintomas em praticamente todas as espécies de Citrus além de outros gêneros da família Rutaceae (Gottwald et al., 1993; Graham et al., 1992). Em razão da existência de oụtros patovares de Xanthomonas axonopodis patogênicos em citros, aurantifolii e citrumelo, o cancro cítrico também é denominado "cancro cítrico Asiático" ou "cancrose A". O patovar aurantifolii possui como hospedeiro apenas limões verdadeiros e limas ácidas, sob 
condições naturais de infecção, tendo sido localizado somente na América do Sul. Em razão de diferenças quanto a patogenicidade e localização geográfica, o patovar aurantifolii possui dois tipos bacterianos, denominados "B" $\mathrm{e}$ "C". O patovar citrumelo, também com patogenicidade limitada e ocorrência restrita a Flórida, possui a denominação de "tipo E" (Gabriel et al., 1988; Graham et al., 1990; Pruvost et al., 1992; Vernière et al., 1993). Há também dois outros tipos bacterianos formados por isolados do patovar citri com patogenicidade diferenciada e restrita a lima ácida 'galego' (Citrus aurantifolia), o primeiro encontrado no sudoeste asiático (tipo $\mathrm{A}^{*}$ ) (Vernière et al., 1998) e o segundo na Flórida (tipo $A^{w}$ ) (Sun et al., 2000; Sun et al., 2004).

A genotipagem de isolados de Xanthomonas patogênicos em Citrus tem sido feita objetivando, preferencialmente, a diferenciação dos patovares existentes. Padrões obtidos pela clivagem do DNA por enzimas de restrição e reassociação de DNA demonstraram perfis similares entre os tipos A e B, e maiores diferenças destes dois grupos com o tipo E. A similaridade média entre estes três grupos foi de $60 \%$ por reassociação de DNA. Os cinco isolados testados pertencentes ao tipo A foram similares entre si no mínimo em 90\% (Egel et al., 1991). Resultados similares foram obtidos pela comparação dos perfis genéticos gerados por clivagem do DNA por enzimas de restrição e Southern blot (RFLP-restriction fragment length polymorphism) usando-se como sonda um cluster do gene hrp (Leite Jr. et al., 1994). Relativo polimorfismo foi observado entre os grupos patogênicos de Xanthomonas, mas não dentro de cada patovar. Em outro estudo, a caracterização metabólica baseada na utilização do sistema Biolog não correlacionou-se com a origem geográfica, hospedeiro e ano de isolamento (Vernière et al., 1993). Mais recentemente, a genotipagem de uma coleção mundial de isolados de Xac por BOX (BOX elements) e ERIC-PCR (enterobacterial repetitive intergenic consensus) permitiu a relativa caracterização de grupos genéticos e separou parcialmente isolados distantes geograficamente, como os originários da Ásia e América, e tạmbém os com patogenicidade diferenciada (tipos $A^{*}$ e $A^{W}$ ). As similaridades médias encontradas entre os isolados de Xac estudados foram superiores a 85 e 87\% para BOX e ERIC, respectivamente (Cubero \& Graham, 2002). Como sugerem os autores, a existência de genótipos comuns entre a Flórida e a América do Sul 
e Ásia, identificados por BOX e ERIC-PCR, pode ser em razão da introdução do patógeno na região metropolitana de Miami por material vegetal infectado (Graham et al., 2004).

$\mathrm{O}$ estudo de patógenos bacterianos geneticamente similares, objetivando a caracterização da estrutura genética da população, tem sido feito para patógenos humanos e vegetais por Southern blot (RFLP) empregando-se como sondas seqüências de inserção (insertion sequences-IS) ou genes avr (Hermans et al., 1990; Leach et al., 1995; Van Soolingen et al., 1991). Como exemplo, a tipagem molecular por IS-RFLP de Mycobacterium tuberculosis, agente causal da tuberculose, é a técnica ideal em estudos que objetivam a identificação da origem de casos da doença (Otal et al., 1991). A avaliação da diversidade genética de patógenos vegetais por Southern blot (RFLP), usando-se como sondas IS, tem como melhores exemplos os realizados com $X$. oryzae pv. oryzae, $X$. pv. mangiferaeindicae e $X$. axonopodis pv. manihotis (Adhikari et al., 1999; Gagnevin et al., 1997; Nelson et al., 1994; Ochiai et al., 2000; Restrepo et al., 2000). O emprego desta técnica revelou uma diferenciação temporal e espacial de $X$. oryzae na Ásia, a migração do patógeno entre regiões e países, e a divisão da população do patógeno em grupos relacionados com as condições climáticas do local de origem, patogenicidade e raças (Adhikari et al., 1999; Leach et al., 1992; Nelson et al., 1994; Ochiai et al., 2000). Com a mesma técnica, a diversidade genética de isolados de uma população mundial de $X$. pv. mangiferaeindicae foi caracterizada e os grupos genéticos formados correlacionaram-se com a região de origem e o hospedeiro. Maior diversidade foi encontrada entre isolados da Ásia, o centro de origem do patossistema, e isolados com patogenicidade diferenciada e originários de outros hospedeiros agruparam-se distintamente (Gagnevin et al., 1997).

O desenvolvimento de técnicas laboratoriais visando um acurado conhecimento da estrutura genética de populações de Xac permitiria o entendimento da história evolutiva do patógeno (Lenski, 1993). Técnicas com boa reprodutibilidade, poder discriminatório e facilidade de uso poderiam ser usadas, por exemplo, na identificação da origem de focos da doença, como realizado para M. tuberculosis (Graham et al., 2004; Otal et al., 1991; Van Soolingen et al., 1991). Diante disso, o 
presente estudo objetivou a identificação e caracterização da diversidade genética de isolados de Xanthomonas axonopodis pv. citri, originários do Estado de São Paulo, empregando-se as técnicas de Southern blot (RFLP) e fluorescent amplified fragment length polymorphism (FAFLP), e a geração de informações que possam ser úteis na caracterização da estrutura genética da população e na identificação/detecção da origem de focos da doença.

\subsection{Material e métodos}

\subsubsection{Isolados bacterianos}

Cento e oitenta isolados de Xac foram utilizados no presente estudo. Os isolados foram conservados em glicerol $\left(20 \%,-80^{\circ} \mathrm{C}\right)$ e liofilizados, mantidos a temperatura ambiente. Todos isolados originários de São Paulo foram obtidos de plantas sintomáticas em condições naturais de infecção, ocorridas entre 1979 e 2003. Quarenta e seis isolados, provenientes das coleções de culturas IBSBF (Instituto Biológico de São Paulo, Seção de Bacteriologia e Fitopatologia) e IAPAR (Instituto Agronômico do Paraná) representam focos da doença ocorridos em diferentes municípios do Estado, anos e hospedeiros (Tabela 1). Para comparação foram também utilizados os isolados 306, sequenciado pelo projeto Genoma/FAPESP (da Silva et al., 2002), e o patótipo de Xac CFBP 2525. Outros 77 isolados representam focos da doença ocorridos em quatro pomares comerciais, localizados nos municípios de Iacri, Urupês, Novo Horizonte e Álvares Florence (Tabela 2). Cada isolado foi obtido de uma planta sintomática e todos os isolados do mesmo município são originários de plantas doentes do mesmo pomar. Por último, foram utilizados 55 isolados originários de um mesmo pomar, cada um de uma planta, localizado na antiga Estação de Pesquisas em Cancro Cítrico, do Instituto Biológico de São Paulo, no município de Presidente Prudente. 
Tabela 1 - Isolados de Xanthomonas axonopodis pv. citri originários de focos de cancro cítrico ocorridos no Estado de São Paulo entre 1979 e 2001 e respectivos origens geográficas, anos de isolamento e hospedeiros

\begin{tabular}{|c|c|c|c|}
\hline Isolados & Origem geográfica & Ano de isolamento & Hospedeiro \\
\hline IBSBF220 & Monte Alto & 1980 & Citrus reticulata \\
\hline IBSBF 221 & Monte Alto & 1980 & Citrus reticulata \\
\hline IBSBF 283 & Araçatuba & 1980 & Citrus aurantifolia \\
\hline $306^{1}$ & Paranavaí & 1997 & Citrus sinensis \\
\hline IBSBF 314 & Araçatuba & 1979 & Citrus sinensis \\
\hline IBSBF 338 & Cândido Mota & 1981 & Citrus sinensis \\
\hline IBSBF 347 & Cruzália & 1981 & Citrus sinensis \\
\hline IBSBF 349 & Fernando Prestes & 1981 & Citrus aurantifolia \\
\hline IBSBF 364 & Campos Novos Paulista & 1981 & Citrus aurantifolia \\
\hline IBSBF 416 & Planalto & 1982 & Citrus aurantifolia \\
\hline IBSBF 438 & Cajobí & 1982 & Citrus aurantifolia \\
\hline IBSBF 924 & Brotas & 1991 & Citrus spp. \\
\hline IBSBF 982 & Santa Maria da Serra & 1993 & Citrus latifolia \\
\hline IBSBF 1404 & São João da Boa Vista & 1998 & Citrus sinensis \\
\hline IBSBF 1415 & Engenheiro Coelho & 1998 & Citrus sinensis \\
\hline IBSBF 1420 & Novo Horizonte & 1998 & Citrus latifolia \\
\hline IBSBF 1421 & Casa Branca & 1998 & Citrus sinensis \\
\hline IBSBF 1422 & Novo Horizonte & 1998 & Citrus sinensis \\
\hline IBSBF 1432 & Paulínea & 1999 & Citrus sinensis \\
\hline IBSBF 1434 & Presidente Bernardes & 1999 & Citrus latifolia \\
\hline IBSBF 1435 & Engenheiro Coelho & 1999 & Citrus latifolia \\
\hline IBSBF 1474 & Guzolândia & 1999 & Citrus sinensis \\
\hline IBSBF 1515 & Presidente Prudente & 2000 & Citrus sinensis \\
\hline IBSBF 1568 & Lins & 2001 & Citrus aurantifolia \\
\hline 12333 & Cosmorama & 1998 & Citrus sinensis \\
\hline 12335 & Ilha Solteira & 1998 & Citrus sinensis \\
\hline 12353 & Jaci & 1998 & Citrus sinensis \\
\hline 12405 & Lins & 1999 & Citrus sinensis \\
\hline 12411 & Getulina & 1999 & Citrus sinensis \\
\hline 12418 & Uru & 1999 & Citrus sinensis \\
\hline 12701 & Descalvado & 1999 & Citrus sinensis \\
\hline 12702 & Iacanga & 1999 & Citrus sinensis \\
\hline 12706 & Reginópolis & 1999 & Citrus sinensis \\
\hline 12708 & Cafelândia & 1999 & Citrus sinensis \\
\hline 12710 & Bebedouro & 1999 & Citrus sinensis \\
\hline 12714 & Iacanga & 1999 & Citrus sinensis \\
\hline 12715 & Monte Azul Paulista & 1999 & Citrus sinensis \\
\hline 12826 & Guaimbé & 2000 & C. sinensis $\times C$. reticulata \\
\hline 12833 & Ibitinga & 2001 & Citrus sinensis \\
\hline 12969 & Ibitinga & 2001 & Citrus sinensis \\
\hline 12984 & Echaporã & 2001 & Citrus spp. \\
\hline 12985 & Paraguaçu Paulista & 20001 & Citrus spp. \\
\hline 12988 & Platina & 2001 & Citrus spp. \\
\hline 12992 & Tarumã & 2001 & Citrus spp. \\
\hline 13000 & Salto Grande & 2001 & Citrus latifolia \\
\hline
\end{tabular}

'Isolado utilizado no projeto Genoma/Fapesp 
Tabela 1 - Isolados de Xanthomonas axonopodis pv. citri originários de focos de cancro cítrico ocorridos no Estado de São Paulo entre 1979 e 2001 e respectivos origens geográficas, anos de isolamento e hospedeiros

\begin{tabular}{lccc}
\hline \multicolumn{1}{c}{ Isolados } & Origem geográfica & Ano de isolamento & Hospedeiro \\
\hline 13005 & Aparecida D'Oeste & 2001 & Citrus sinensis \\
13013 & Araras & 2001 & Citrus sinensis \\
13016 & Ourinhos & 2001 & Citrus sinensis \\
13017 & Ourinhos & 2001 & Citrus sinensis \\
CFBP $2525^{2}$ & Nova Zelândia & 1956 & Citrus limon \\
${ }^{2}$ Isolado patotipo de Xanthomonas axonopodis pv. citri &
\end{tabular}

Tabela 2 - Isolados de Xanthomonas axonopodis pv. citri originários de plantas doentes presentes em cinco pomares nos municípios de Presidente Prudente, Iacri, Urupês, Novo Horizonte e Álvares Florence, Estado de São Paulo

\begin{tabular}{|c|c|c|c|}
\hline Isolados & Origem geográfica & Ano de isolamento & Hospedeiro \\
\hline FDC 200 & Presidente Prudente & 2001 & Citrus sinensis \\
\hline FDC 201 & Presidente Prudente & 2001 & Citrus sinensis \\
\hline FDC 202 & Presidente Prudente & 2001 & Citrus sinensis \\
\hline FDC 210 & Presidente Prudente & 2001 & Citrus sinensis \\
\hline FDC 213 & Presidente Prudente & 2001 & Citrus sinensis \\
\hline FDC 214 & Presidente Prudente & 2001 & Citrus sinensis \\
\hline FDC 216 & Presidente Prudente & 2001 & Citrus sinensis \\
\hline FDC 217 & Presidente Prudente & 2001 & Citrus sinensis \\
\hline FDC 274 & Presidente Prudente & 2001 & Citrus sinensis \\
\hline FDC 276 & Presidente Prudente & 2001 & Citrus sinensis \\
\hline FDC 277 & Presidente Prudente & 2001 & Citrus sinensis \\
\hline FDC 278 & Presidente Prudente & 2001 & Citrus sinensis \\
\hline FDC 279 & Presidente Prudente & 2001 & Citrus sinensis \\
\hline FDC 280 & Presidente Prudente & 2001 & Citrus sinensis \\
\hline FDC 281 & Presidente Prudente & 2001 & Citrus sinensis \\
\hline FDC 282 & Presidente Prudente & 2001 & Citrus sinensis \\
\hline FDC 284 & Presidente Prudente & 2001 & Citrus sinensis \\
\hline FDC 285 & Presidente Prudente & 2001 & Citrus sinensis \\
\hline FDC 287 & Presidente Prudente & 2001 & Citrus sinensis \\
\hline FDC 288 & Presidente Prudente & 2001 & Citrus sinensis \\
\hline FDC 291 & Presidente Prudente & 2001 & Citrus sinensis \\
\hline FDC 292 & Presidente Prudente & 2001 & Citrus sinensis \\
\hline FDC 293 & Presidente Prudente & 2001 & Citrus sinensis \\
\hline FDC 294 & Presidente Prudente & 2001 & Citrus sinensis \\
\hline FDC 295 & Presidente Prudente & 2001 & Citrus sinensis \\
\hline FDC 296 & Presidente Prudente & 2001 & Citrus sinensis \\
\hline FDC 297 & Presidente Prudente & 2001 & Cituins sinensis \\
\hline FDC 299 & Presidente Prudente & 2001 & Citrus sinensis \\
\hline FDC 300 & Presidente Prudente & 2001 & Citrus sinensis \\
\hline FDC 302 & Presidente Prudente & 2001 & Citrus sinensis \\
\hline FDC 304 & Presidente Prudente & 2001 & Citrus sinensis \\
\hline FDC 306 & Presidente Prudente & 2001 & Citrus sinensis \\
\hline
\end{tabular}


Tabela 2 - Isolados de Xanthomonas axonopodis pv. citri originários de plantas doentes presentes em cinco pomares nos municípios de Presidente Prudente, Iacri, Urupês, Novo Horizonte e Álvares Florence, Estado de São Paulo

\begin{tabular}{|c|c|c|c|}
\hline Isolados & Origem geográfica & Ano de isolamento & Hospedeiro \\
\hline FDC 307 & Presidente Prudente & 2001 & Citrus sinensis \\
\hline FDC 308 & Presidente Prudente & 2001 & Citrus sinensis \\
\hline FDC 309 & Presidente Prudente & 2001 & Citrus sinensis \\
\hline FDC 310 & Presidente Prudente & 2001 & Citrus sinensis \\
\hline FDC 312 & Presidente Prudente & 2001 & Citrus sinensis \\
\hline FDC 313 & Presidente Prudente & 2001 & Citrus sinensis \\
\hline FDC 315 & Presidente Prudente & 2001 & Citrus sinensis \\
\hline FDC 316 & Presidente Prudente & 2001 & Citrus sinensis \\
\hline FDC 317 & Presidente Prudente & 2001 & Citrus sinensis \\
\hline FDC 318 & Presidente Prudente & 2001 & Citrus sinensis \\
\hline FDC 323 & Presidente Prudente & 2001 & Citrus sinensis \\
\hline FDC 324 & Presidente Prudente & 2001 & Citrus sinensis \\
\hline FDC 326 & Presidente Prudente & 2001 & Citrus sinensis \\
\hline FDC 330 & Presidente Prudente & 2001 & Citrus sinensis \\
\hline FDC 331 & Presidente Prudente & 2001 & Citrus sinensis \\
\hline FDC 339 & Presidente Prudente & 2001 & Citrus sinensis \\
\hline FDC 358 & Presidente Prudente & 2001 & Citrus sinensis \\
\hline FDC 359 & Presidente Prudente & 2001 & Citrus sinensis \\
\hline FDC 360 & Presidente Prudente & 2001 & Citrus sinensis \\
\hline FDC 361 & Presidente Prudente & 2001 & Citrus sinensis \\
\hline FDC 362 & Presidente Prudente & 2001 & Citrus sinensis \\
\hline FDC 363 & Presidente Prudente & 2001 & Citrus sinensis \\
\hline FDC 364 & Presidente Prudente & 2001 & Citrus sinensis \\
\hline FDC 501 & Iacri & 2002 & Citrus sinensis \\
\hline FDC 503 & Iacri & 2002 & Citrus sinensis \\
\hline FDC 504 & Iacri & 2002 & Citrus sinensis \\
\hline FDC 505 & Iacri & 2002 & Citrus sinensis \\
\hline FDC 507 & Iacri & 2002 & Citrus sinensis \\
\hline FDC 508 & Iacri & 2002 & Citrus sinensis \\
\hline FDC 509 & Iacri & 2002 & Citrus sinensis \\
\hline FDC 510 & Iacri & 2002 & Citrus sinensis \\
\hline FDC 511 & Iacri & 2002 & Citrus sinensis \\
\hline FDC 512 & Iacri & 2002 & Citrus sinensis \\
\hline FDC 513 & Iacri & 2002 & Citrus sinensis \\
\hline FDC 516 & Iacri & 2002 & Citrus sinensis \\
\hline FDC 518 & Iacri & 2002 & Citrus sinensis \\
\hline FDC 519 & Iacri & 2002 & Citrus sinensis \\
\hline FDC 521 & Iacri & 2002 & Citrus sinensis \\
\hline FDC 522 & Iacri & 2002 & Citrus sinensis \\
\hline FDC 526 & Iacri & 2002 & Citrus sinensis \\
\hline FDC 539 & Iacri & 2002 & Citrus sinensis \\
\hline FDC 717 & Urupês & 2002 & Citrus sinensis \\
\hline FDC 720 & Urupês & 2002 & Citrus sinensis \\
\hline FDC 721 & Urupês & 2002 & Citrus sinensis \\
\hline FDC 722 & Urupês & 2002 & Citrus sinensis \\
\hline
\end{tabular}


Tabela 2 - Isolados de Xanthomonas axonopodis pv. citri originários de plantas doentes presentes em cinco pomares nos municípios de Presidente Prudente, Iacri, Urupês, Novo Horizonte e Álvares Florence, Estado de São Paulo

\begin{tabular}{|c|c|c|c|}
\hline Isolados & Origem geográfica & Ano de isolamento & Hospedeiro \\
\hline FDC 723 & Urupês & 2002 & Citrus sinensis \\
\hline FDC 724 & Urupês & 2002 & Citrus sinensis \\
\hline FDC 727 & Urupês & 2002 & Citrus sinensis \\
\hline FDC 728 & Urupês & 2002 & Citrus sinensis \\
\hline FDC 729 & Urupês & 2002 & Citrus sinensis \\
\hline FDC 730 & Urupês & 2002 & Citrus sinensis \\
\hline FDC 731 & Urupês & 2002 & Citrus sinensis \\
\hline FDC 732 & Urupês & 2002 & Citrus sinensis \\
\hline FDC 733 & Urupês & 2002 & Citrus sinensis \\
\hline FDC 734 & Urupês & 2002 & Citrus sinensis \\
\hline FDC 735 & Urupês & 2002 & Citrus sinensis \\
\hline FDC 736 & Urupês & 2002 & Citrus sinensis \\
\hline FDC 737 & Urupês & 2002 & Citrus sinensis \\
\hline FDC 738 & Urupês & 2002 & Citrus sinensis \\
\hline FDC 739 & Urupês & 2002 & Citrus sinensis \\
\hline FDC 740 & Urupês & 2002 & Citrus sinensis \\
\hline FDC 741 & Urupês & 2002 & Citrus sinensis \\
\hline FDC 743 & Urupês & 2002 & Citrus sinensis \\
\hline FDC 902 & Novo Horizonte & 2003 & Citrus sinensis \\
\hline FDC 903 & Novo Horizonte & 2003 & Citrus sinensis \\
\hline FDC 904 & Novo Horizonte & 2003 & Citrus sinensis \\
\hline FDC 905 & Novo Horizonte & 2003 & Citrus sinensis \\
\hline FDC 906 & Novo Horizonte & 2003 & Citrus sinensis \\
\hline FDC 907 & Novo Horizonte & 2003 & Citrus sinensis \\
\hline FDC 912 & Novo Horizonte & 2003 & Citrus sinensis \\
\hline FDC 913 & Novo Horizonte & 2003 & Citrus sinensis \\
\hline FDC 916 & Novo Horizonte & 2003 & Citrus sinensis \\
\hline FDC 917 & Novo Horizonte & 2003 & Citrus sinensis \\
\hline FDC 918 & Novo Horizonte & 2003 & Citrus sinensis \\
\hline FDC 921 & Novo Horizonte & 2003 & Citrus sinensis \\
\hline FDC 922 & Novo Horizonte & 2003 & Citrus sinensis \\
\hline FDC 923 & Novo Horizonte & 2003 & Citrus sinensis \\
\hline FDC 924 & Novo Horizonte & 2003 & Citrus sinensis \\
\hline FDC 925 & Novo Horizonte & 2003 & Citrus sinensis \\
\hline FDC 926 & Novo Horizonte & 2003 & Citrus sinensis \\
\hline FDC 928 & Novo Horizonte & 2003 & Citrus sinensis \\
\hline FDC 930 & Novo Horizonte & 2003 & Citrus sinensis \\
\hline FDC 931 & Novo Horizonte & 2003 & Citrus sinensis \\
\hline FDC 940 & Novo Horizonte & 2003 & Citrus sinensis \\
\hline FDC 948 & Novo Horizonte & 2003 & Citrus sinensis \\
\hline FDC 959 & Álvares Florence & 2003 & Citrus sinensis \\
\hline FDC 964 & Álvares Florence & 2003 & Citrus sinensis \\
\hline FDC 966 & Álvares Florence & 2003 & Citrus sinensis \\
\hline FDC 969 & Álvares Florence & 2003 & Citrus sinensis \\
\hline FDC 972 & Álvares Florence & 2003 & Citrus sinensis \\
\hline
\end{tabular}


Tabela 2 - Isolados de Xanthomonas axonopodis pv. citri originários de plantas doentes presentes em cinco pomares nos municípios de Presidente Prudente, Iacri, Urupês, Novo Horizonte e Álvares Florence, Estado de São Paulo

\begin{tabular}{clcc}
\hline Isolados & Origem geográfica & Ano de isolamento & Hospedeiro \\
\hline FDC 976 & Álvares Florence & 2003 & Citrus sinensis \\
FDC 993 & Átvares Florence & 2003 & Citrus sinensis \\
FDC 994 & Álvares Florence & 2003 & Citrus sinensis \\
FDC 995 & Álvares Florence & 2003 & Citrus sinensis \\
FDC 996 & Álvares Florence & 2003 & Citrus sinensis \\
FDC 1000 & Álvares Florence & 2003 & Citrus sinensis \\
FDC 1002 & Álvares Florence & 2003 & Citrus sinensis \\
FDC 1006 & Álvares Florence & 2003 & Citrus sinensis \\
\hline
\end{tabular}

\subsubsection{Southern blot (RFLP)}

Os isolados cresceram em meio de cultura YP (extrato de levedura, $7 \mathrm{~g} / \mathrm{l}$, peptona, $7 \mathrm{~g} / \mathrm{l}, \mathrm{pH} 7,0)$ por $14 \mathrm{~h}$ a $28^{\circ} \mathrm{C}$, sob agitação $(200 \mathrm{rpm})$. A extração de DNA foi pelo método de brometo de hexadeciltrimetilamônio (Ausubel, 1991). Alíquotas de 2 $\mathrm{mL}$ foram centrifugadas $\left(7500 \mathrm{rpm}, 5 \mathrm{~min} ., 20^{\circ} \mathrm{C}\right)$ e o pellet misturado com tampão lise contendo $500 \mu \mathrm{L}$ de TE pH 8,0 (Tris $10 \mathrm{mM}$, EDTA $1 \mathrm{mM}$ ), $30 \mu \mathrm{L}$ de SDS (10\%), e 4 $\mu \mathrm{L}$ de proteinase $\mathrm{K}\left(10 \mathrm{mg}^{\mathrm{ml}} \mathrm{l}^{-1}\right)$. Após 1 hora a $37^{\circ} \mathrm{C}, 100 \mu \mathrm{L}$ de $\mathrm{NaCl}(5 \mathrm{M}), 80 \mu \mathrm{L}$ de $\mathrm{CTAB}(10 \%)$ e $\mathrm{NaCl}(0,7 \mathrm{M})$ foram adicionados e os tubos incubados por $30 \mathrm{~min}$. a $65^{\circ} \mathrm{C}$. Um igual volume de clorofórmio:isoamilálcool (24:1) foi adicionado e os tubos foram centrifugados por $25 \mathrm{~min}$. a $13000 \mathrm{rpm}\left(20^{\circ} \mathrm{C}\right)$. Após recuperação do sobrenadante, o DNA foi precipitado pela adição de igual volume de isopropanol. Após centrifugação, o pellet foi lavado duas vezes com etanol (70\%), e ressuspendido em TE pH 8,0. O DNA foi quantificado espectrofotomericamente (espectrofotômetro Lambda EZ201, Applied Biosystems) e mantido a $-20^{\circ} \mathrm{C}$.

O DNA foi clivado com endonuclease PstI (Gibco) por aproximadamente 14 horas a $37^{\circ} \mathrm{C}$ como recomendado pelo fabricante. Fragmentos da restrição foram separados por eletroforese em gel de agarose $(1 \%, 20 \times 22 \mathrm{~cm})\left(\right.$ Gibco) a $1,5 \mathrm{~V} . \mathrm{cm}^{-1}$ por aproximadamente 21h. Após depurinação em solução $\mathrm{HCl}(0,25 \mathrm{~N})$ e denaturação em solução $\mathrm{NaOH}(0,4 \mathrm{~N})$, os fragmentos de DNA foram transferidos por capilaridade para 
membranas de nylon carregadas positivamente (Hybond $\mathrm{N}+$, Amersham). O DNA foi fixado nas membranas após manuntenção destas a $80^{\circ} \mathrm{C}$ por 2 horas.

Um plasmídeo vetor (pUC18) contendo uma cópia da seqüência de inserção ISXac2 foi utilizado diretamente como sonda para hibridação. Esse plasmídeo foi obtido da coleção genômica construída para o sequenciamente de Xac (da Silva, 2002). Para as seqüências de inserção ISXac1 e ISXac3, dois primers foram usados para amplificação (PCR) de fragmentos de aproximadamente 500 bp de cada IS (primers 5'GACTTCAGATCACGAAATGC3' e 5'AACGCTTCTTGCAACAGCTC3' para ISXacl e primers 5'GCGTAAGGCTCCCATTGATA3' e 5'GCAAAACCCGGCACATCGCG3' para ISXac3). A solução de PCR usada para amplificação continha 1x tampão Taq, $\mathrm{MgCl}_{2}$ a $2 \mathrm{mM}$, cada dNTP (200 mM, cada), primers (100 nM, cada) e $3 \mathrm{U}$ de Taq polimerase (Gibco). A amplificação foi iniciada a $30 \mathrm{~s}$ a $94^{\circ} \mathrm{C}$ para denaturação, seguida por 30 ciclos de $30 \mathrm{~s}$ a $94^{\circ} \mathrm{C}, 30 \mathrm{~s}$ a $55^{\circ} \mathrm{C}$ e 2 min a $72^{\circ} \mathrm{C}$, finalizando em incubação a $4^{\circ} \mathrm{C}$. O produto dos PCRs (ISXacl e 3) e o plasmídeo vetor contendo o ISXac2 foram utilizados como sondas e a marcação destas, a hibridação e a detecção em raio X foram realizadas com o kit ECL (Direct Nucleic Acid Labeling), de acordo com as recomendações do fabricante (Amersham).

\subsubsection{Análise dos dados de RFLP}

Os perfis genéticos obtidos para cada isolado após hibridação foram comparados entre si e a ausência de bandas foi definida como zero e a presença como um. Somente foram consideradas as bandas fortes para definição de score um. Considerou-se como haplótipo cada perfil único de seqüência de bandas e isolados com as mesma seqüência foram considerados como pertencentes ao mesmo haplótipo. Haplótipos diferentes foram comparados no mínimo duas vezes, na mesma e em diferentes membranas, a partir de extrações de DNA independentes para a comparação da reprodutibilidade do método. A matriz de similaridade foi calculada usando o coeficiente de Jaccard e o dendograma construído pelo método de UNJ (unweighted neighbor joining) (Gascuel, 1997) tendo-se usado o software DarWIN 4.0 (CIRAD, 
Montpellier, France). A robustez dos dendogramas foi calculada pela análise de bootstrap usando o mesmo programa (1000 repetições).

Considerando as diferentes origens dos isolados, estes foram agrupados em: a) isolados de diferentes municípios de São Paulo, anos e hospedeiros, considerando os isolados apresentados na Tabela $1(\mathrm{n}=48)$; b) isolados de Presidente Prudente, considerando todos os apresentados na Tabela $2(n=55)$; c) isolados de Iacri $(n=18) ; d)$ isolados de Urupês $(n=22)$; e) isolados de Novo Horizonte $(n=22)$; e f) isolados de Álvares Florence $(n=13)$. Estes diferentes grupos foram comparados quanto a diversidade haplotípica pelo índice de Shannon $\left(H^{\prime}\right)$ (Magurran, 1988), tendo-se utilizado a seguinte fórmula:

$$
H^{\prime}=-\Sigma p_{i} \cdot \ln \left(p_{i}\right)
$$

sendo $p_{i}$ a proporção de cada haplótipo. A variância de $H^{\prime}$ foi calculada da seguinte forma:

$$
\text { Variância de } H^{\prime}=\left(\Sigma p_{i \cdot} \cdot\left(\ln p_{i}\right)^{2}-\left(\sum p_{i} \cdot \ln p_{i}\right)^{2}\right) / \mathrm{n}+\left((\mathrm{S}-1) / 2 . \mathrm{n}^{2}\right) \text {, }
$$

sendo $\mathrm{n}$ o número de isolados na população avaliada e $\mathrm{S}$ o número de haplótipos. As diferenças significativas $(p<0,05)$ entre os índices foram calculadas pelo teste $t$ :

$$
t=\left(H_{1}^{\prime}-H_{2}^{\prime}\right) /\left(\text { Variância de } H_{1}^{\prime}+\text { Variância de } H_{2}^{\prime}\right)^{1 / 2} \text {, }
$$

sendo $H_{1}^{\prime}$ e $H_{2}^{\prime}$ os índices de duas populações hipotéticas 1 e 2 . O número de graus de liberdade $(d f)$ para a comparação com os valores tabelados de $t$ foi calculado usando-se:

$$
\begin{gathered}
d f=\left(\text { Variância de } H_{1}^{\prime}+\text { Variância de } H_{2}^{\prime}\right)^{2} /\left(\left(\text { Variância de } H_{1}^{\prime}\right)^{2} / \mathrm{n}_{1}+(\text { Variância de }\right. \\
\left.\left.\qquad H_{2}^{\prime}\right)^{2} / \mathrm{n}_{2}\right)
\end{gathered}
$$


A diversidade genética entre e em cada grupo definido de isolados também foi avaliada pelo índice de diversidade genética de Nei e análise molecular de variância (AMOVA), ambos calculados pelo software Arlequin ver. 2000 (Schneider et al., 2000).

\subsubsection{Fluorescent amplified fragment length polymorphism (FAFLP)}

Todos os 180 isolados de Xac (Tabelas 1 e 2) foram analisados por FAFLP. As condições de cultivo foram as mesmas descritas para RFLP e para a extração de DNA foi seguida a recomendação de Brenner et al. (1982) tendo-se utilizado o kit Dneasy (Qiagen). O DNA foi quantificado espectrofotometricamente (espectrofotômetro Lambda EZ201, Applied Biosystems) e mantido a $-20^{\circ} \mathrm{C}$. A digestão de DNA (4 $\mu \mathrm{L}$ a 25 ng. $\mu \mathrm{L}^{-1}$ ) foi realizada num volume final de $25 \mu \mathrm{L}$ contendo $0,50 \mu \mathrm{L}$ de endonuclease SacI (20 U. $\left.\mu \mathrm{L}^{-1}\right)$ (New England Biolabs), 0,10 $\mu \mathrm{L}$ de endonuclease MspI $\left(20 \mathrm{U} \mu \mathrm{L}^{-1}\right)$ (New England Biolabs), 0,25 $\mu \mathrm{L}$ de BSA (100x) (New England Biolabs) e 2,50 $\mu \mathrm{L}$ de tampão NEB 1 (10x) (New England Biolabs) por $1 \mathrm{~h} \mathrm{a} 37^{\circ} \mathrm{C}$. A ligação dos adaptadores foi feita num volume final de $25 \mu \mathrm{L}$ contendo $2,50 \mu \mathrm{L}$ da solução de digestão, $2,50 \mu \mathrm{L}$ de tampão T4 ligase (10x) (Amersham), 2,50 $\mu \mathrm{L}$ de T4 ligase (4 $\left.\mathrm{U} \mu \mathrm{L}^{-1}\right)$ (Amersham), $2,50 \mu \mathrm{L}$ de adaptador $\operatorname{SacI}(2 \mu \mathrm{M})$ e $2,50 \mu \mathrm{L}$ de adaptador $M s p I(20 \mu \mathrm{M})$ (Applied Biosystems) por $3 \mathrm{~h} \mathrm{a} 37^{\circ} \mathrm{C}$. Duas amplifiações sucessivas foram realizadas. Na primeira um volume final de $15 \mu \mathrm{L}$ contendo $1,5 \mu \mathrm{L}$ de tampão Taq polimerase (10x) (Eurogentec), 0,7 $\mu \mathrm{L}$ de dNTP (10mM cada), $0,35 \mu \mathrm{L}$ de cada primer (SacI e MspI) (10 $\mu \mathrm{M}$ ), 1,50 $\mu \mathrm{L}$ de $\mathrm{MgCl}_{2}$ (Eurogentec), 0,10 $\mu \mathrm{L}$ de Taq polimerase $(5 \mathrm{U} / \mu \mathrm{L}$ ) (Red Goldstar Eurogentec) e 5,00 $\mu \mathrm{L}$ da solução de ligação diluída $10 \mathrm{x}$. A reação de amplificação consistiu nas incubações a $72^{\circ} \mathrm{C}$ por $2 \min$ e $94^{\circ} \mathrm{C}$ por $2 \mathrm{~min}$, seguida de 25 ciclos de denaturação por $30 \mathrm{~s} \mathrm{a} 94^{\circ} \mathrm{C}$, anelamento por $30 \mathrm{~s}$ a $56^{\circ} \mathrm{C}$ e elongação por 2 min a $72^{\circ} \mathrm{C}$. Ao final incubação por $10 \mathrm{~min}$ a $72^{\circ} \mathrm{C}$ e depois $12^{\circ} \mathrm{C}$. A segunda amplificação (seletiva) foi realizada com um volume final de $15 \mu \mathrm{L}$ contendo $1,5 \mu \mathrm{L}$ de tampão Taq polimerase (10x) (Eurogentec), 0,7 $\mu \mathrm{L}$ de dNTP (10mM cada), 0,18 $\mu \mathrm{L}$ do primer seletivo $\mathrm{SacI}$ marcado $(\mathrm{SacI}+\mathrm{C})(10 \mu \mathrm{M}), 0,35 \mu \mathrm{L}$ de um dos quatro primers seletivos $M s p I$ não marcados (MspI + A, MspI + T, MspI + G ou $M s p I+\mathrm{C})(10 \mu \mathrm{M}$ 
cada), um em cada reação, $1,50 \mu \mathrm{L}$ de $\mathrm{Mg}_{\mathrm{g}} \mathrm{Cl}_{2}$ (Eurogentec), $0,10 \mu \mathrm{L}$ de Taq polimerase $(5 \mathrm{U} / \mu \mathrm{L})$ (Red Goldstar Eurogentec) e $5,00 \mu \mathrm{L}$ da solução da primeira amplificação diluída 10x. Esta segunda reação de amplificação consistiu numa incubação a $94^{\circ} \mathrm{C}$ por 5 min, seguida de 13 ciclos de denaturação por $30 \mathrm{~s} \mathrm{a} 94^{\circ} \mathrm{C}$, anelamento por $30 \mathrm{~s} \mathrm{a} 65^{\circ} \mathrm{C} \mathrm{e}$ elongação por $2 \mathrm{~min}$, com um decréscimo de $0,7^{\circ} \mathrm{C}$ da temperatura de anelamento a cada ciclo, mais 24 ciclos de denaturação por $30 \mathrm{~s}$ a $94^{\circ} \mathrm{C}$, anelamento por $30 \mathrm{~s} \mathrm{a} 56^{\circ} \mathrm{C} \mathrm{e}$ elongação por $2 \min$ a $72^{\circ} \mathrm{C}$. Ao final incubação por $10 \mathrm{~min}$ a $72^{\circ} \mathrm{C}$ e depois $12^{\circ} \mathrm{C}$. As seqüências dos adaptadores e primers SacI e MspI estão apresentadas na Tabela 3. As reações de amplificação foram realizadas em termociclor PE-9700 (Applied Biosystems). Um microlito de cada amplificação seletiva foi adicionado a $18,7 \mu \mathrm{L}$ de formamida e 0,3 $\mu \mathrm{L}$ de marcador $500 \mathrm{LIZ}$ Genescan (Applied Biosystems), denaturado a $95^{\circ} \mathrm{C}$ por $5 \mathrm{~min}$ e colocados no gelo por $5 \mathrm{~min}$. As amostras foram submetidas a eletroforese capilar por $35 \mathrm{~min}(15 \mathrm{kV})$ em sequenciador ABI-3100 (Applied Biosystems).

\subsubsection{Análise dos dados de FAFLP}

Os perfis genéticos obtidos foram comparados por observação visual usando o software Genescan (Applied Biosystems). A ausência e presença de picos foram definidas como zero e um, respectivamente, e uma matriz binária foi composta para cada combinação de primers SacI + C/MspI + A, T, G ou C. Considerou-se como haplótipo cada perfil único de seqüência de picos e isolados com as mesma seqüência foram considerados como pertencentes ao mesmo haplótipo. Haplótipos diferentes foram comparados no mínimo duas vezes, na mesma e em diferentes manipulações, a partir de extrações de DNA independentes para a comparação da reprodutibilidade do método. A matriz de similaridade foi calculada usando o coeficiente de Jaccard (NTSYS 2.0) e o dendograma construído pelo método de UNJ (unweighted neighbor joining) (Gascuel, 1997) tendo-se usado o software DarWIN 4.0 (CIRAD, Montpellier, France). A robustez dos dendogramas foi calculada pela análise de bootstrap usando o mesmo programa (1000 repetições). 
Tabela 3 - Seqüências dos adaptadores e primers SacI e MspI utilizados na genotipagem por FAFLP

\begin{tabular}{lc}
\hline \multicolumn{1}{c}{ Oligonucleotídeo } & Seqüência $^{1}$ \\
\hline Adaptadores SacI & 5'-CTCGTAGACTGCGTACAAGCT-3' \\
Adaptadores $M s p I$ & 3'-TGTACGCAGTCTACG-5' \\
& 5'-GACGATGAGTCCTGAG-3' \\
Primer SacI & 3'-CGCTCAGGACTCATC-5' \\
Primer $M s p I$ & 5'-TAGACTGCGTACAAGCTC-3' \\
Primer seletivo SacI & 5'-GATGAGTCCTGAGCGG-3' \\
Primer seletivo $M s p I$ & 5'-TAGACTGCGTACAAGCTC (N)-3' \\
'Os nucleotídeos seletivos utilizados na posição 3' dos primers seletivos SacI e MspI estão representados \\
por N.
\end{tabular}

\subsection{Resultados}

Um total de 30, 34 e 17 haplótipos foram identificados usando as sondas ISXac1, ISXac2 e ISXac3, respectivamente. Todos os isolados testados hibridaram com as três sondas. Considerando-as conjuntamente, um total de 64 haplótipos foi identificado dentre os 180 isolados estudados (Tabela 4). O número de bandas/haplótipo variou de seis a dez para ISXac1 e 2 e de 19 a 21 para ISXac3. O número total de bandas utilizadas na definição de haplótipos foi de 28, 40 e 38 para ISXac1, ISXac2 e ISXac3, respectivamente. Para cada uma das sondas utilizadas, um dos haplótipos apresentou-se como majoritário (haplótipo 1) e 45,65; 58,70 e 82,61\% dos 48 isolados que representam municípios de São Paulo apresentaram este mesmo perfil quando hibridado com ISXac1, 2 e 3, respectivamente (Tabela 5). Combinando-se os resultados das três sondas, $26,09 \%$ destes isolados apresentaram o haplótipo denominado 1 (Tabelas 5 e 6). Considerando apenas os 48 isolados descritos na Tabela 1 o número de haplótipos únicos (representados apenas por um isolado) foi de 15, 12 e oito para as sondas ISXac1, 2 e 3, respectivamente, e 28 para as três sondas. O isolado CFBP 2525 (patótipo de Xac) apresentou-se como haplótipo único independentemente da sonda utilizada, enquanto o isolado sequenciado pelo Projeto Genoma/FAPESP (306) apresentou-se como único apenas para ISXac3, embora sempre distinto do perfil majoritário do Estado para as sondas ISXac1 e 2. 


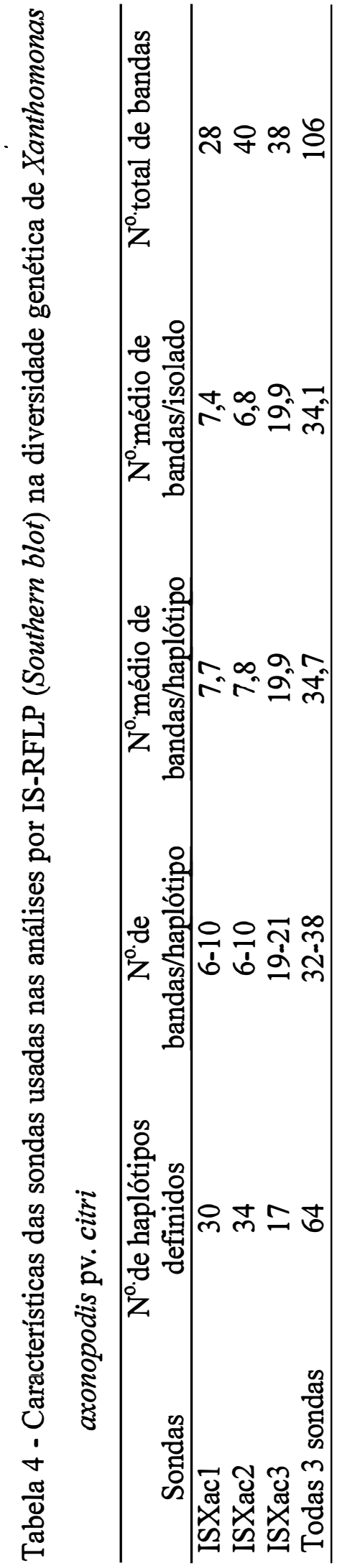


Tabela 5 - Haplótipos de Xanthomonas axonopodis pv. citri originários de focos de cancro cítrico ocorridos em São Paulo entre 1979 e 2001 por IS-RFLP e FAFLP

\begin{tabular}{|c|c|c|c|c|c|c|c|c|c|c|}
\hline \multirow[t]{2}{*}{ Isolados } & \multirow[t]{2}{*}{ Origem geográfica } & \multicolumn{4}{|c|}{ IS-RFLP } & \multicolumn{5}{|c|}{ FAFLP (SacC) } \\
\hline & & ISXacl & ISXac2 & ISXac3 & ISXac & MspA & MspT & MspG & MspC & MspATGC \\
\hline IBSBF220 & Monte Alto & 1 & 1 & 1 & 1 & 1 & 1 & 1 & 1 & 1 \\
\hline IBSBF 221 & Monte Alto & 1 & 1 & 1 & 1 & 1 & 1 & 1 & 2 & 2 \\
\hline IBSBF 283 & Aracatuba & 2 & 1 & 1 & 2 & 1 & 1 & 1 & 2 & 2 \\
\hline 306 & Paranavaí & 2 & 2 & 2 & 3 & 1 & 1 & 1 & 2 & 2 \\
\hline IBSBF 314 & Araçatuba & 1 & 3 & 1 & 4 & 1 & 1 & 1 & 2 & 2 \\
\hline IBSBF 338 & Cândido Mota & 3 & 2 & 1 & 5 & 1 & 1 & 1 & 2 & 2 \\
\hline IBSBF 347 & Cruzália & 1 & 1 & 1 & 1 & 1 & 1 & 1 & 2 & 2 \\
\hline IBSBF 349 & Fernando Prestes & 4 & 1 & 1 & 6 & 1 & 1 & 1 & 2 & 2 \\
\hline IBSBF 364 & C. Novos Paulista & 1 & 1 & 1 & 1 & 1 & 1 & 1 & 2 & 2 \\
\hline IBSBF 416 & Planalto & 1 & 1 & 1 & 1 & 1 & 1 & 1 & 2 & 2 \\
\hline IBSBF 438 & Cajobi & 2 & 1 & 1 & 2 & 1 & 1 & 1 & 2 & 2 \\
\hline IBSBF 924 & Brotas & 5 & 1 & 1 & 7 & 1 & 1 & 1 & 2 & 2 \\
\hline IBSBF 982 & Santa Maria da Serra & 6 & 4 & 1 & 8 & 1 & 1 & 1 & 2 & 2 \\
\hline IBSBF 1404 & S. João da Boa Vista & 1 & 5 & 1 & 9 & 1 & 1 & 1 & 2 & 2 \\
\hline IBSBF 1415 & Engenheiro Coelho & 1 & 1 & 1 & 1 & 1 & 1 & 1 & 2 & 2 \\
\hline IBSBF 1420 & Novo Horizonte & 7 & 6 & 1 & 10 & 1 & 1 & 1 & 2 & 2 \\
\hline IBSBF 1421 & Casa Branca & 1 & 1 & 1 & 1 & 1 & 1 & 1 & 2 & 2 \\
\hline IBSBF 1422 & Novo Horizonte & 8 & 6 & 1 & 11 & 1 & 1 & 1 & 2 & 2 \\
\hline IBSBF 1432 & Paulínea & 1 & 1 & 1 & 1 & 1 & 1 & 1 & 2 & 2 \\
\hline IBSBF 1434 & Presidente Bernardes & 9 & 7 & 1 & 12 & 1 & 1 & 1 & 2 & 2 \\
\hline IBSBF 1435 & Engenheiro Coelho & 1 & 1 & 1 & 1 & 1 & 1 & 1 & 2 & 2 \\
\hline IBSBF 1474 & Guzolândia & 10 & 8 & 3 & 13 & 2 & 1 & 1 & 2 & 3 \\
\hline IBSBF 1515 & Presidente Prudente & 11 & 7 & 1 & 14 & 1 & 1 & 1 & 2 & 2 \\
\hline IBSBF 1568 & Lins & 12 & 1 & 1 & 15 & 1 & 1 & 1 & 2 & 2 \\
\hline 12333 & Cosmorama & 13 & 1 & 1 & 16 & 1 & 1 & 1 & 2 & 2 \\
\hline 12335 & Ilha Solteira & 1 & 1 & 1 & 1 & 1 & 1 & 1 & 2 & 2 \\
\hline 12353 & Jaci & 14 & 8 & 3 & 17 & 1 & 1 & 1 & 2 & 2 \\
\hline 12405 & Lins & 1 & 9 & 1 & 18 & 1 & 1 & 1 & 2 & 2 \\
\hline 12411 & Getulina & 1 & 10 & 4 & 19 & 1 & 1 & 1 & 2 & 2 \\
\hline 12418 & Uru & 15 & 11 & 5 & 20 & 1 & 1 & 1 & 2 & 2 \\
\hline 12701 & Descalvado & 1 & 7 & 1 & 21 & 1 & 1 & 1 & 2 & 2 \\
\hline 12702 & Iacanga & 15 & 1 & 1 & 22 & 1 & 1 & 1 & 2 & 2 \\
\hline 12706 & Reginópolis & 15 & 1 & 1 & 22 & 1 & 1 & 1 & 2 & 2 \\
\hline 12708 & Cafelândia & 16 & 1 & 1 & 23 & 1 & 1 & 1 & 2 & 2 \\
\hline 12710 & Bebedouro & 3 & 12 & 6 & 24 & 1 & 1 & 1 & 2 & 2 \\
\hline 12714 & Iacanga & 17 & 1 & 1 & 25 & 1 & 1 & 1 & 2 & 2 \\
\hline 12715 & Monte Azul Paulista & 1 & 1 & 1 & 1 & 1 & 1 & 1 & 2 & 2 \\
\hline 12826 & Guaimbé & 13 & 1 & 1 & 16 & 1 & 2 & 1 & 3 & 4 \\
\hline 12833 & Ibitinga & 13 & 1 & 7 & 26 & 1 & 1 & 1 & 2 & 2 \\
\hline 12969 & Ibitinga & 4 & 13 & 1 & 27 & 1 & 1 & 1 & 2 & 2 \\
\hline 12984 & Echaporã & 18 & 1 & 8 & 28 & 1 & 1 & 1 & 2 & 2 \\
\hline 12985 & Paraguaçu Paulista & 4 & 1 & 1 & 6 & 1 & 1 & 1 & 2 & 2 \\
\hline 12988 & Platina & 1 & 14 & 1 & 29 & 1 & 1 & 1 & 2 & 2 \\
\hline 12992 & Tarumã & 1 & 15 & 9 & 30 & 1 & 1 & 1 & 2 & 2 \\
\hline 13000 & Salto Grande & 19 & 16 & 10 & 31 & 1 & 1 & 1 & 2 & 2 \\
\hline 13005 & Aparecida D'Oeste & 1 & 1 & 1 & 1 & 1 & 1 & 1 & 2 & 2 \\
\hline 13013 & Araras & 20 & 1 & 8 & 32 & 1 & 1 & 1 & 2 & 2 \\
\hline 13016 & Ourinhos & 1 & 17 & 1 & 33 & 1 & 1 & 1 & 2 & 2 \\
\hline 13017 & Ourinhos & 1 & 14 & 1 & 29 & 1 & 1 & 1 & 2 & 2 \\
\hline CFBP 2525 & Nova Zelândia & 21 & 18 & 11 & 34 & 1 & 1 & 1 & 2 & 2 \\
\hline
\end{tabular}


Tabela 6 - Haplótipos de Xanthomonas axonopodis pv. citri originários de plantas doentes presentes em cinco pomares nos municípios de Presidente Prudente, Iacri, Urupês, Novo Horizonte e Álvares Florence, estado de São Paulo, por IS-RFLP e FAFLP

\begin{tabular}{|c|c|c|c|c|c|c|c|c|c|c|}
\hline \multirow[t]{2}{*}{ Isolados } & \multirow[t]{2}{*}{ Origem geográfica } & \multicolumn{4}{|c|}{ RFLP } & \multicolumn{5}{|c|}{ AFLP (SacC) } \\
\hline & & ISXacl & ISXac2 & ISXac3 & ISXac & MspA & MspT & MspG & $\mathrm{MspC}$ & MspATGC \\
\hline FDC 200 & Presidente Prudente & 11 & 7 & 1 & 14 & 1 & 1 & 1 & 2 & 2 \\
\hline FDC 201 & Presidente Prudente & 11 & 7 & 1 & 14 & 1 & 1 & 1 & 2 & 2 \\
\hline FDC 202 & Presidente Prudente & 11 & 7 & 1 & 14 & 1 & 1 & 1 & 2 & 2 \\
\hline FDC 210 & Presidente Prudente & 22 & 19 & 1 & 35 & 1 & 1 & 1 & 2 & 2 \\
\hline FDC 213 & Presidente Prudente & 22 & 19 & 1 & 35 & 1 & 1 & 1 & 2 & 2 \\
\hline FDC 214 & Presidente Prudente & 11 & 20 & 1 & 36 & 1 & 1 & 1 & 2 & 2 \\
\hline FDC 216 & Presidente Prudente & 11 & 7 & 1 & 14 & 1 & 1 & 1 & 2 & 2 \\
\hline FDC 217 & Presidente Prudente & 11 & 21 & 1 & 37 & 1 & 1 & 1 & 2 & 2 \\
\hline FDC 274 & Presidente Prudente & 11 & 22 & 1 & 38 & 1 & 1 & 1 & 2 & 2 \\
\hline FDC 276 & Presidente Prudente & 11 & 7 & 1 & 14 & 1 & 1 & 1 & 2 & 2 \\
\hline FDC 277 & Presidente Prudente & 11 & 7 & 7 & 39 & 1 & 1 & 1 & 2 & 2 \\
\hline FDC 278 & Presidente Prudente & 11 & 23 & 7 & 40 & 1 & 1 & 1 & 2 & 2 \\
\hline FDC 279 & Presidente Prudente & 11 & 7 & 1 & 14 & 1 & 1 & 1 & 2 & 2 \\
\hline FDC 280 & Presidente Prudente & 11 & 7 & 1 & 14 & 1 & 1 & 1 & 2 & 2 \\
\hline FDC 281 & Presidente Prudente & 11 & 7 & 1 & 14 & 1 & 1 & 1 & 2 & 2 \\
\hline FDC 282 & Presidente Prudente & 11 & 24 & 1 & 41 & 1 & 1 & 1 & 2 & 2 \\
\hline FDC 284 & Presidente Prudente & 11 & 25 & 1 & 42 & 1 & 1 & 1 & 2 & 2 \\
\hline FDC 285 & Presidente Prudente & 11 & 20 & 1 & 36 & 1 & 1 & 1 & 2 & 2 \\
\hline FDC 287 & Presidente Prudente & 11 & 7 & 1 & 14 & 1 & 1 & 1 & 2 & 2 \\
\hline FDC 288 & Presidente Prudente & 11 & 22 & 1 & 38 & 1 & 1 & 1 & 2 & 2 \\
\hline FDC 291 & Presidente Prudente & 11 & 20 & 1 & 36 & 1 & 1 & 1 & 2 & 2 \\
\hline FDC 292 & Presidente Prudente & 11 & 26 & 1 & 43 & 1 & 1 & 1 & 2 & 2 \\
\hline FDC 293 & Presidente Prudente & 23 & 20 & 1 & 44 & 1 & 1 & 1 & 2 & 2 \\
\hline FDC 294 & Presidente Prudente & 11 & 23 & 7 & 40 & 1 & 1 & 1 & 2 & 2 \\
\hline FDC 295 & Presidente Prudente & 11 & 7 & 1 & 14 & 1 & 1 & 1 & 2 & 2 \\
\hline FDC 296 & Presidente Prudente & 11 & 7 & 1 & 14 & 1 & 1 & 1 & 2 & 2 \\
\hline FDC 297 & Presidente Prudente & 11 & 27 & 7 & 45 & 1 & 1 & 1 & 2 & 2 \\
\hline FDC 299 & Presidente Prudente & 9 & 7 & 7 & 46 & 1 & 1 & 1 & 2 & 2 \\
\hline FDC 300 & Presidente Prudente & 11 & 7 & 1 & 14 & 1 & 1 & 1 & 2 & 2 \\
\hline FDC 302 & Presidente Prudente & 11 & 7 & 7 & 39 & 1 & 1 & 1 & 4 & 5 \\
\hline FDC 304 & Presidente Prudente & 24 & 7 & 8 & 47 & 1 & 1 & 1 & 2 & 2 \\
\hline FDC 306 & Presidente Prudente & 11 & 7 & 1 & 14 & 1 & 1 & 1 & 2 & 2 \\
\hline FDC 307 & Presidente Prudente & 25 & 7 & 12 & 48 & 1 & 1 & 1 & 2 & 2 \\
\hline FDC 308 & Presidente Prudente & 26 & 28 & 7 & 49 & 1 & 1 & 1 & 2 & 2 \\
\hline FDC 309 & Presidente Prudente & 11 & 7 & 1 & 14 & 1 & 1 & 1 & 2 & 2 \\
\hline FDC 310 & Presidente Prudente & 13 & 7 & 1 & 50 & 1 & 1 & 1 & 2 & 2 \\
\hline FDC 312 & Presidente Prudente & 1 & 29 & 1 & 51 & 1 & 1 & 1 & 2 & 2 \\
\hline FDC 313 & Presidente Prudente & 27 & 7 & 1 & 52 & 1 & 1 & 1 & 2 & 2 \\
\hline FDC 315 & Presidente Prudente & 11 & 7 & 1 & 14 & 1 & 1 & 1 & 2 & 2 \\
\hline FDC 316 & Presidente Prudente & 27 & 7 & 1 & 52 & 1 & 1 & 1 & 2 & 2 \\
\hline FDC 317 & Presidente Prudente & 1 & 7 & 1 & 21 & 1 & 1 & 1 & 2 & 2 \\
\hline FDC 318 & Presidente Prudente & 11 & 7 & 1 & 14 & 1 & 1 & 1 & 2 & 2 \\
\hline FDC 323 & Presidente Prudente & 11 & 30 & 1 & 53 & 1 & 1 & 1 & 2 & 2 \\
\hline FDC 324 & Presidente Prudente & 11 & 31 & 1 & 54 & 3 & 1 & 1 & 2 & 6 \\
\hline FDC 326 & Presidente Prudente & 9 & 32 & 1 & 55 & 1 & 1 & 1 & 2 & 2 \\
\hline FDC 330 & Presidente Prudente & 11 & 7 & 1 & 14 & 1 & 1 & 1 & 2 & 2 \\
\hline FDC 331 & Presidente Prudente & 11 & 7 & 1 & 14 & 1 & 1 & 1 & 2 & 2 \\
\hline FDC 339 & Presidente Prudente & 11 & 7 & 1 & 14 & 1 & 1 & 1 & 2 & 2 \\
\hline FDC 358 & Presidente Prudente & 11 & 7 & 7 & 39 & 1 & 1 & 1 & 2 & 2 \\
\hline FDC 359 & Presidente Prudente & 11 & 7 & 1 & 14 & 1 & 1 & 1 & 2 & 2 \\
\hline FDC 360 & Presidente Prudente & 11 & 7 & 7 & 39 & 1 & 1 & 1 & 2 & 2 \\
\hline FDC 361 & Presidente Prudente & 11 & 7 & 7 & 39 & 1 & 1 & 1 & 2 & 2 \\
\hline FDC 362 & Presidente Prudente & 11 & 7 & 1 & 14 & 1 & 1 & 1 & 2 & 2 \\
\hline FDC 363 & Presidente Prudente & 11 & 7 & 1 & 14 & 1 & 1 & 1 & 2 & 2 \\
\hline FDC 364 & Presidente Prudente & 11 & 7 & 1 & 14 & 1 & 1 & I & 2 & 2 \\
\hline FDC 501 & Iacri & 4 & 1 & 13 & 56 & 1 & 1 & 1 & 2 & 2 \\
\hline
\end{tabular}


Tabela 6 - Haplótipos de Xanthomonas axonopodis pv. citri originários de plantas doentes presentes em cinco pomares nos municípios de Presidente Prudente, Iacri, Urupês, Novo Horizonte e Álvares Florence, estado de São Paulo, por IS-RFLP e FAFLP

\begin{tabular}{|c|c|c|c|c|c|c|c|c|c|c|}
\hline \multirow[t]{2}{*}{ Isolados } & \multirow[t]{2}{*}{ Origem geográfica } & \multicolumn{4}{|c|}{ RFLP } & \multicolumn{5}{|c|}{ AFLP $(\mathrm{SacC})$} \\
\hline & & ISXacl & ISXac2 & ISXac3 & ISXac & MspA & MspT & MspG & MspC & MspATGC \\
\hline FDC 503 & Iacri & 4 & 1 & 13 & 56 & 1 & 1 & 1 & 2 & 2 \\
\hline FDC 504 & Iacri & 1 & 1 & 13 & 57 & 1 & 1 & 1 & 2 & 2 \\
\hline FDC 505 & Iacri & 4 & 1 & 13 & 56 & 1 & 1 & 1 & 2 & 2 \\
\hline FDC 507 & Iacri & 4 & 1 & 13 & 56 & 1 & 1 & 1 & 2 & 2 \\
\hline FDC 508 & Iacri & 4 & 1 & 13 & 56 & 1 & 1 & 1 & 2 & $\cdot 2$ \\
\hline FDC 509 & Iacri & 4 & 1 & 13 & 56 & 1 & 1 & 1 & 2 & 2 \\
\hline FDC 510 & Iacri & 1 & 1 & 13 & 57 & 1 & 1 & 1 & 2 & 2 \\
\hline FDC 511 & Iacri & 1 & 1 & 13 & 57 & 1 & 1 & 1 & 2 & 2 \\
\hline FDC 512 & Iacri & 4 & 1 & 13 & 56 & 1 & 1 & 1 & 2 & 2 \\
\hline FDC 513 & Iacri & 4 & 1 & 13 & 56 & 1 & 1 & 1 & 2 & 2 \\
\hline FDC 516 & Iacri & 1 & 1 & 13 & 57 & 1 & 1 & 1 & 2 & 2 \\
\hline FDC 518 & Iacri & 1 & 1 & 13 & 57 & 1 & 1 & 1 & 2 & 2 \\
\hline FDC 519 & Iacri & 28 & 1 & 14 & 58 & 1 & 1 & 1 & 2 & 2 \\
\hline FDC 521 & Iacri & 4 & 1 & 13 & 56 & 1 & 1 & 1 & 2 & 2 \\
\hline FDC 522 & Iacri & 4 & 1 & 13 & 56 & 1 & 1 & 1 & 2 & 2 \\
\hline FDC 526 & Iacri & 17 & 1 & 14 & 59 & 1 & 1 & 1 & 2 & 2 \\
\hline FDC 539 & Iacri & 4 & 1 & 15 & 60 & 1 & 1 & 1 & 2 & 2 \\
\hline FDC 717 & Urupês & 29 & 33 & 16 & 61 & 2 & 1 & 1 & 2 & 3 \\
\hline FDC 720 & Urupês & 29 & 33 & 16 & 61 & 2 & 1 & 1 & 2 & 3 \\
\hline FDC 721 & Urupês & 29 & 33 & 16 & 61 & 2 & 1 & 1 & 2 & 3 \\
\hline FDC 722 & Urupês & 29 & 33 & 16 & 61 & 2 & 1 & 1 & 2 & 3 \\
\hline FDC 723 & Urupês & 29 & 33 & 16 & 61 & 2 & 1 & 1 & 2 & 3 \\
\hline FDC 724 & Urupês & 29 & 33 & 16 & 61 & 2 & 1 & 1 & 2 & 3 \\
\hline FDC 727 & Urupês & 29 & 33 & 16 & 61 & 2 & 1 & 1 & 2 & 3 \\
\hline FDC 728 & Urupês & 29 & 33 & 16 & 61 & 2 & 1 & 1 & 2 & 3 \\
\hline FDC 729 & Urupês & 29 & 33 & 17 & 62 & 2 & 1 & 1 & 2 & 3 \\
\hline FDC 730 & Urupês & 29 & 33 & 16 & 61 & 2 & 1 & 1 & 2 & 3 \\
\hline FDC 731 & Urupês & 29 & 33 & 16 & 61 & 2 & 1 & 1 & 2 & 3 \\
\hline FDC 732 & Urupês & 29 & 33 & 16 & 61 & 2 & 1 & 1 & 2 & 3 \\
\hline FDC 733 & Urupês & 29 & 33 & 16 & 61 & 2 & 1 & 1 & 2 & 3 \\
\hline FDC 734 & Urupês & 29 & 33 & 16 & 61 & 2 & 1 & 1 & 2 & 3 \\
\hline FDC 735 & Urupês & 29 & 33 & 16 & 61 & 2 & 1 & 1 & 2 & 3 \\
\hline FDC 736 & Urupês & 29 & 33 & 16 & 61 & 2 & 1 & 1 & 2 & 3 \\
\hline FDC 737 & Urupês & 29 & 33 & 16 & 61 & 2 & 1 & 1 & 2 & 3 \\
\hline FDC 738 & Urupês & 29 & 33 & 16 & 61 & 2 & 1 & 1 & 2 & 3 \\
\hline FDC 739 & Urupês & 29 & 33 & 16 & 61 & 2 & 1 & 1 & 2 & 3 \\
\hline FDC 740 & Urupês & 29 & 33 & 16 & 61 & 2 & 1 & 1 & 2 & 3 \\
\hline FDC 741 & Urupês & 29 & 33 & 16 & 61 & 2 & 1 & 1 & 2 & 3 \\
\hline FDC 743 & Urupês & 29 & 33 & 16 & 61 & 2 & 1 & 1 & 2 & 3 \\
\hline FDC 902 & Novo Horizonte & 15 & 1 & 1 & 22 & 1 & 1 & 1 & 2 & 2 \\
\hline FDC 903 & Novo Horizonte & 15 & 1 & 1 & 22 & 1 & 1 & 1 & 2 & 2 \\
\hline FDC 904 & Novo Horizonte & 13 & 1 & 1 & 16 & 1 & 1 & 1 & 2 & 2 \\
\hline FDC 905 & Novo Horizonte & 15 & 1 & 1 & 22 & 1 & 1 & 1 & 2 & 2 \\
\hline FDC 906 & Novo Horizonte & 15 & 1 & 1 & 22 & 1 & 1 & 1 & 2 & 2 \\
\hline FDC 907 & Novo Horizonte & 13 & 1 & 1 & 16 & 1 & 1 & 1 & 2 & 2 \\
\hline FDC 912 & Novo Horizonte & 15 & 1 & 1 & 22 & 1 & 1 & 1 & 2 & 2 \\
\hline FDC 913 & Novo Horizonte & 15 & 1 & 1 & 22 & 1 & 1 & 1 & 2 & 2 \\
\hline FDC 916 & Novo Horizonte & 13 & 1 & 1 & 16 & 1 & 1 & 1 & 2 & 2 \\
\hline FDC 917 & Novo Horizonte & 15 & 1 & 1 & 22 & 1 & 1 & 1 & 2 & 2 \\
\hline FDC 918 & Novo Horizonte & 15 & 1 & 1 & 22 & 1 & 1 & 1 & 2 & 2 \\
\hline FDC 921 & Novo Horizonte & 13 & 1 & 1 & 16 & 1 & 1 & 1 & 2 & 2 \\
\hline FDC 922 & Novo Horizonte & 15 & 1 & 1 & 22 & 1 & 1 & 1 & 2 & 2 \\
\hline FDC 923 & Novo Horizonte & 13 & 1 & 1 & 16 & 1 & 1 & 1 & 2 & 2 \\
\hline FDC 924 & Novo Horizonte & 15 & 1 & 1 & 22 & 1 & 1 & 1 & 2 & 2 \\
\hline FDC 925 & Novo Horizonte & 15 & 1 & 1 & 22 & 1 & 1 & 1 & 2 & 2 \\
\hline FDC 926 & Novo Horizonte & 13 & 1 & 1 & 16 & 1 & 1 & 1 & 2 & 2 \\
\hline
\end{tabular}


Tabela 6 - Haplótipos de Xanthomonas axonopodis pv. citri originários de plantas doentes presentes em cinco pomares nos municípios de Presidente Prudente, Iacri, Urupês, Novo Horizonte e Álvares Florence, estado de São Paulo, por IS-RFLP e FAFLP

\begin{tabular}{llccccccccc}
\hline Isolados & Origern geográfica & \multicolumn{1}{c}{ RFLP } & \multicolumn{1}{c}{ AFLP(SacC) } \\
& & ISXacl & ISXac2 & ISXac3 & ISXac & MspA & MspT & MspG & MspC & MspATGC \\
\hline FDC 928 & Novo Horizonte & 15 & 1 & 1 & 22 & 1 & 1 & 1 & 2 & 2 \\
FDC 930 & Novo Horizonte & 13 & 1 & 1 & 16 & 1 & 1 & 1 & 2 & 2 \\
FDC 931 & Novo Horizonte & 15 & 1 & 1 & 22 & 1 & 1 & 1 & 2 & 2 \\
FDC 940 & Novo Horizonte & 13 & 1 & 1 & 16 & 1 & 1 & 1 & 2 & 2 \\
FDC 948 & Novo Horizonte & 13 & 1 & 1 & 16 & 1 & 1 & 1 & 2 & 2 \\
FDC 959 & Álvares Florence & 13 & 34 & 1 & 63 & 1 & 1 & 1 & 2 & 2 \\
FDC 964 & Álvares Florence & 13 & 1 & 1 & 16 & 1 & 1 & 1 & 2 & 2 \\
FDC 966 & Álvares Florence & 13 & 1 & 1 & 16 & 1 & 1 & 1 & 2 & 2 \\
FDC 969 & Álvares Florence & 13 & 1 & 1 & 16 & 1 & 1 & 1 & 2 & 2 \\
FDC 972 & Álvares Florence & 15 & 1 & 1 & 22 & 1 & 1 & 1 & 2 & 2 \\
FDC 976 & Álvares Florence & 15 & 1 & 1 & 22 & 1 & 1 & 1 & 2 & 2 \\
FDC 993 & Álvares Florence & 13 & 1 & 1 & 16 & 1 & 1 & 1 & 2 & 2 \\
FDC 994 & Álvares Florence & 30 & 1 & 1 & 64 & 1 & 1 & 1 & 2 & 2 \\
FDC 995 & Álvares Florence & 15 & 1 & 1 & 22 & 1 & 1 & 1 & 2 & 2 \\
FDC 996 & Álvares Florence & 13 & 1 & 1 & 16 & 1 & 1 & 1 & 2 & 2 \\
FDC 1000 & Álvares Florence & 13 & 1 & 1 & 16 & 1 & 1 & 1 & 2 & 2 \\
FDC 1002 & Álvares Florence & 13 & 1 & 1 & 16 & 1 & 1 & 1 & 2 & 2 \\
FDC 1006 & Álvares Florence & 13 & 1 & 1 & 16 & 1 & 1 & 1 & 2 \\
\hline
\end{tabular}

O número de haplótipos identificados variou em cada uma das "populações" definidas no presente estudo, assim como os índices de diversidade genética (Nei). Para cada uma das sondas sempre um maior número de haplótipos foi identificado entre os 48 isolados que representam os municípios de São Paulo, em comparação com os isolados originários de plantas doentes presentes em cinco pomares nos municípios de Presidente Prudente, Iacri, Urupês, Novo Horizonte e Álvares Florence. Dentre estes, maiores números de haplótipos foram identificados dentre os isolados de Presidente Prudente. Apenas um único haplótipo foi identificado em Urupês com ISXacl e ISXac2, em Iacri com ISXac2, em Novo Horizonte com ISXac2 e 3 e em Álvares Florence com ISXac3 (Tabelas 7 a 9). Os índices de diversidade genética variaram de 0,09 (Urupês) a 0,94 (municípios de SP), considerando as seis populações estudadas e as três sondas (Tabela 10). Maiores índices de diversidade genética foram observados com ISXacl para as populações de "municípios de SP", Iacri, Novo Horizonte e Álvares Florence, em comparação com ISXac2 e 3, enquanto com ISXac2 para Presidente Prudente e ISXac3 para Urupês. Apesar do mesmo número de haplótipos (dois) terem sido encontrados em Urupês e Novo Horizonte, o índice de diversidade genética de Novo Horizonte $(0,51)$ foi 
Tabela 7 - Número de haplótipos identificados, loci polimórficos e índice de diversidade genética (Nei) correspondentes à análise com a sonda ISXac1 de populações de isolados de Xanthomonas axonopodis pv. citri

\begin{tabular}{lccc}
\hline \multicolumn{1}{c}{ População } & $\begin{array}{c}\mathbf{N}^{\mathbf{0}} \text { haplótipos } \\
\text { identificados }\end{array}$ & $\mathbf{N}^{\mathbf{0}}$ loci polimórficos & $\begin{array}{c}\text { Diversidade genética } \pm \\
\text { d.p. }\end{array}$ \\
\hline Municípios de SP & 20 & 18 & $0,80 \pm 0,06$ \\
Presidente Prudente & 10 & 11 & $0,42 \pm 0,08$ \\
Iacri & 4 & 3 & $0,58 \pm 0,10$ \\
Urupês & 1 & 0 & $0,00 \pm 0,00$ \\
Novo Horizonte & 2 & 2 & $0,51 \pm 0,05$ \\
Álvares Florence & 3 & 3 & $0,50 \pm 0,14$ \\
\hline
\end{tabular}

${ }^{1}$ Corresponde aos 48 isolados originários de municípios de São Paulo listados na Tabela 1.

Tabela 8 - Número de haplótipos identificados, loci polimórficos e índice de diversidade genética (Nei) correspondentes à análise com a sonda ISXac2 de populações de isolados de Xanthomonas axonopodis pv. citri

\begin{tabular}{lccc}
\hline \multicolumn{1}{c}{ População } & $\begin{array}{c}\mathbf{N}^{\mathbf{0}} \text { haplótipos } \\
\text { identificados }\end{array}$ & $\mathbf{N}^{\mathbf{0}}$ loci polimórficos & $\begin{array}{c}\text { Diversidade genética } \pm \\
\text { d.p. }\end{array}$ \\
\hline Municípios de SP & 17 & 21 & $0,68 \pm 0,08$ \\
Presidente Prudente & 15 & 14 & $0,59 \pm 0,08$ \\
Iacri & 1 & 0 & $0,00 \pm 0,00$ \\
Urupês & 1 & 0 & $0,00 \pm 0,00$ \\
Novo Horizonte & 1 & 0 & $0,00 \pm 0,00$ \\
Álvares Florence & 2 & 2 & $0,15 \pm 0,13$ \\
\hline
\end{tabular}

${ }^{\top}$ Corresponde aos 48 isolados originários de municípios de São Paulo listados na Tabela 1.

Tabela 9 - Número de haplótipos identificados, loci polimórficos e índice de diversidade genética (Nei) correspondentes à análise com a sonda ISXac3 de populações de isolados de Xanthomonas axonopodis pv. citri

\begin{tabular}{lccc}
\hline \multicolumn{1}{c}{ População } & $\begin{array}{c}\mathbf{N}^{\mathbf{0}} \text { haplótipos } \\
\text { identificados }\end{array}$ & $\mathbf{N}^{\mathbf{0}}$ loci polimórficos & $\begin{array}{c}\text { Diversidade genética } \pm \\
\text { d.p. }\end{array}$ \\
\hline Municípios de SP & 9 & 22 & $0,38 \pm 0,09$ \\
Presidente Prudente & 4 & 6 & $0,36 \pm 0,07$ \\
Iacri & 3 & 4 & $0,31 \pm 0,13$ \\
Urupês & 2 & 3 & $0,09 \pm 0,08$ \\
Novo Horizonte & 1 & 0 & $0,00 \pm 0,00$ \\
Álvares Florence & 1 & 0 & $0,00 \pm 0,00$ \\
\hline
\end{tabular}

${ }^{1}$ Corresponde aos 48 isolados originários de municípios de São Paulo listados na Tabela 1. 
mais que cinco vezes superior ao observado para Urupês $(0,09)$ (Tabela 10). Isto ocorreu em razão do haplótipo 62 de Urupês ser representado por apenas um isolado, enquanto 13 e nove isolados representarem os haplótipos 22 e 16, respectivamente, de Novo Horizonte (Tabela 6). O cálculo do índice de diversidade genética de Nei considera a freqüência observada de haplótipos em cada população, o que explica as diferenças observadas para duas populações com o mesmo número de indivíduos $(\mathrm{n}=22)$ e haplótipos.

Os índices de diversidade genética, calculados pela fórmula de Shannon, foram superiores aos observados pelo índice de Nei, excetuando-se os de Presidente Prudente. Os resultados obtidos variaram estatisticamente entre sondas e também entre populações para uma mesma sonda (Tabela 11). Diversidade haplotípica em Novo Horizonte foi identificada apenas pela sonda ISXac1, enquanto em Urupês apenas com ISXac3. Diferenças estatísticas, considerando os resultados das três sondas, foram observadas entre a população de Urupês, com a menor diversidade, e "municípios de SP", Presidente Prudente e Novo Horizonte (Tabela 11). Da mesma forma como calculado o índice de Nei, o índice de Shannon leva em consideração apenas a freqüência de haplótipos. Objetivando comparar as populações também quanto aos haplótipos identificados, e a freqüência destes, fotam calculados os índices de fixação (FST) entre as populações e também para todos os isolados originários de São Paulo. Todas populações diferiram entre si para ISXacl, excetuando-se Novo Horizonte e Álvares Florence (Tabela 12). De fato, os isolados destas duas populações não diferiram entre si para qualquer das sondas (Tabelas 13, 14 e 15). As populações de Novo Horizonte e Álvares Florence não diferiram de Iacri para ISXac2 (Tabela 13), enquanto diferenças não foram observadas entre "municípios de SP", Presidente Prudente e Álvares Florence, para ISXac3, e também entre Álvares Florence e Presidente Prudente para essa mesma sonda (Tabela 14). Enquanto a maior parte das diferenças observadas para FST, com os dados de ISXacl, ocorreram dentro das populações (52\%) (Tabela 12), maiores variações foram observadas entre populações com ISXac2 e 3 (54 e 59\%, respectivamente) (Tabelas 13 e 14). Considerando todas as três sondas, $69 \%$ das variações observadas ocorreram dentro das populações (Tabela 15). 
Tabela 10 - Número de haplótipos identificados, loci polimórficos e índice de diversidade genética (Nei) correspondentes a análise com as sondas ISXac1, 2 e 3 de populações de isolados de Xanthomonas axonopodis pv. citri

\begin{tabular}{lccc}
\hline \multicolumn{1}{c}{ População } & $\begin{array}{c}\mathrm{N}^{\mathbf{0}} \text { haplótipos } \\
\text { identificados }\end{array}$ & $\mathrm{N}^{\mathbf{0} \cdot}$ loci polimórficos & $\begin{array}{c}\text { Diversidade genética } \pm \\
\text { d.p. }\end{array}$ \\
\hline Municípios de SP & 32 & 61 & $0,94 \pm 0,03$ \\
Presidente Prudente & 23 & 31 & $0,82 \pm 0,05$ \\
Iacri & 5 & 7 & $0,64 \pm 0,10$ \\
Urupês & 2 & 3 & $0,09 \pm 0,08$ \\
Novo Horizonte & 2 & 2 & $0,51 \pm 0,05$ \\
Álvares Florence & 4 & 5 & $0,60 \pm 0,13$ \\
\hline
\end{tabular}

${ }^{\mathrm{T}}$ Corresponde aos 48 isolados originários de municípios de São Paulo listados na Tabela 1.

Tabela 11 - Número de isolados e diversidade haplotípica (índice de Shannon) correspondentes à análise com as sondas ISXac1, ISXac2 e ISXac3 de populações de isolados de Xanthomonas axonopodis pv. citri

\begin{tabular}{lccccc}
\hline & & \multicolumn{4}{c}{ Diversidade haplotípica $\left(H^{\prime}\right)^{1}$} \\
\cline { 2 - 5 } \multicolumn{1}{c}{ População } & $\mathrm{N}^{\mathbf{0}}$ de isolados & ISXac1 & ISXac2 & ISXac3 & Todas 3 sondas \\
\hline Municípios de SP & 48 & $0,76 \mathrm{abA}$ & $0,66 \mathrm{aA}$ & $0,43 \mathrm{aA}$ & $0,90 \mathrm{aA}$ \\
Presidente Prudente & 55 & $0,46 \mathrm{bA}$ & $0,58 \mathrm{aA}$ & $0,47 \mathrm{aA}$ & $0,76 \mathrm{aA}$ \\
Iacri & 18 & $0,70 \mathrm{abA}$ & $0,00 \mathrm{bB}$ & $0,51 \mathrm{aA}$ & $0,72 \mathrm{abA}$ \\
Urupês & 22 & $0,00 \mathrm{cB}$ & $0,00 \mathrm{bB}$ & $0,27 \mathrm{aA}$ & $0,27 \mathrm{bA}$ \\
Novo Horizonte & 22 & $0,98 \mathrm{aA}$ & $0,00 \mathrm{bB}$ & $0,00 \mathrm{bB}$ & $0,98 \mathrm{aA}$ \\
Álvares Florence & 13 & $0,72 \mathrm{abA}$ & $0,39 \mathrm{aAB}$ & $0,00 \mathrm{bB}$ & $0,74 \mathrm{abA}$ \\
\hline I Lestras minúsculas indicam a comparação entre as populações nas colunas (para cada sonda) e letras \\
maiúsculas a comparação dentre de cada população (entre sondas). \\
${ }^{1}$ Corresponde aos isolados originários de municípios de São Paulo listados na Tabela 1.
\end{tabular}

Tabela 12 - Índice de fixação (FST) entre populações de isolados de Xanthomonas axonopodis pv. citri e resultados da AMOVA para a análise da diversidade genética com a sonda ISXac1

\begin{tabular}{lccccc}
\hline \multicolumn{1}{c}{ População } & $\begin{array}{c}\text { Municípios } \\
\text { de SP }\end{array}$ & $\begin{array}{c}\text { Presidente } \\
\text { Prudente }\end{array}$ & Iacri & Urupês & $\begin{array}{c}\text { Novo } \\
\text { Horizonte }\end{array}$ \\
\hline Presidente Prudente & $0,37^{*}$ & - & - & - & - \\
Iacri & $0,16^{*}$ & $0,52^{*}$ & - & - & - \\
Urupês & $0,51^{*}$ & $0,72^{*}$ & $0,74^{*}$ & - & - \\
Novo Horizonte & $0,28^{*}$ & $0,55^{*}$ & $0,46^{*}$ & $0,75^{*}$ & - \\
Álvares Florence & $0,28^{*}$ & $0,55^{*}$ & $0,46^{*}$ & $0,81^{*}$ & $0,13^{\text {NS }}$ \\
FST (total)=0,48 $(p<0,0000)$ & & & & & \\
Variação entre populações =48,00\% & & & & & \\
Variação dentro das populações =52,00\% & & & & \\
${ }^{1}$ Corresponde aos isolados originários de municípios de São Paulo listados na Tabela 1.
\end{tabular}


Tabela 13 - Índice de fixação (FST) entre populações de isolados de Xanthomonas axonopodis pv. citri e resultados da AMOVA para a análise da diversidade genética com a sonda ISXac2

\begin{tabular}{|c|c|c|c|c|c|}
\hline População & $\begin{array}{c}\text { Municípios de } \\
\text { SP }^{1}\end{array}$ & $\begin{array}{c}\text { Presidente } \\
\text { Prudente }\end{array}$ & Iacri & Urupês & $\begin{array}{c}\text { Novo } \\
\text { Horizonte }\end{array}$ \\
\hline Presidente Prudente & $0,34^{*}$ & - & - & - & - \\
\hline Iacri & $0,14 *$ & $0,60 *$ & ـ & _ & ـ \\
\hline Urupês & $0,58 *$ & $0,62 *$ & $1,00^{*}$ & ـ & - \\
\hline Novo Horizonte & $0,16^{*}$ & $0,62 *$ & $0,00^{\mathrm{NS}}$ & $1,00^{*}$ & _ \\
\hline Álvarẹs Florence & $0,08^{*}$ & $0,54 *$ & $0,03^{\mathrm{NS}}$ & $0,94 *$ & $0,04^{\mathrm{NS}}$ \\
\hline \multicolumn{6}{|l|}{ FST $($ total $)=0,54(p<0,0000)$} \\
\hline Variação entre populações $=54,32 \%$ & & & & & \\
\hline Variação dentro das populações $=45,68 \%$ & & & & & \\
\hline
\end{tabular}

Tabela 14 - Índice de fixação (FST) entre populações de isolados de Xanthomonas axonopodis pv. citri e resultados da AMOVA para a análise da diversidade genética com a sonda ISXac3

\begin{tabular}{lccccc}
\hline \multicolumn{1}{c}{ População } & $\begin{array}{c}\text { Municípios de } \\
\mathrm{SP}^{1}\end{array}$ & $\begin{array}{c}\text { Presidente } \\
\text { Prudente }\end{array}$ & Iacri & Urupês & $\begin{array}{c}\text { Novo } \\
\text { Horizonte }\end{array}$ \\
\hline Presidente Prudente & $0,02^{\mathrm{NS}}$ & - & - & - & - \\
Iacri & $0,65^{*}$ & $0,66^{*}$ & - & - & - \\
Urupês & $0,73^{*}$ & $0,73^{*}$ & $0,81^{*}$ & - & - \\
Novo Horizonte & $0,06^{*}$ & $0,11^{*}$ & $0,86^{*}$ & $0,96^{*}$ & - \\
Álvares Florence & $0,03^{\mathrm{NS}}$ & $0,08^{\mathrm{NS}}$ & $0,82^{*}$ & $0,94^{*}$ & $0,00^{\mathrm{NS}}$ \\
FST (total) $=0,59(p<0,0000)$ & & & & & \\
Variação entre populações $=59,21 \%$ & & & & & \\
Variação dentro das populações $=40,79 \%$ & & & & \\
Therresponde aos isolados originários de municípios de São Paulo listados na Tabela 1.
\end{tabular}

Tabela 15 - Índice de fixação (FST) entre populações de isolados de Xanthomonas axonopodis pv. citri e resultados da AMOVA para a análise da diversidade genética com as sondas ISXac1, ISXac2 e ISXac3

\begin{tabular}{|c|c|c|c|c|c|}
\hline População & $\begin{array}{c}\text { Municípios de } \\
\text { SP }^{1}\end{array}$ & $\begin{array}{c}\text { Presidente } \\
\text { Prudente }\end{array}$ & Iacri & Urupês & $\begin{array}{c}\text { Novo } \\
\text { Horizonte } \\
\end{array}$ \\
\hline Presidente Prudente & $0,11^{*}$ & - & - & - & - \\
\hline Iacri & $0,19 *$ & $0,26 *$ & - & ـ & - \\
\hline Urupês & $0,41^{*}$ & $0,47 *$ & $0,65^{*}$ & - & - \\
\hline Novo Horizonte & $0,22 *$ & $0,31^{*}$ & $0,43^{*}$ & $0,70^{*}$ & - \\
\hline Álvares Florence & $0,18^{*}$ & $0,27 *$ & $0,38^{*}$ & $0,70^{*}$ & $0,10^{\mathrm{NS}}$ \\
\hline FST $($ total $)=0,31(p<0,0000)$ & & & & & \\
\hline Variação entre populações = $31,26 \%$ & & & & & \\
\hline Variação dentro das populações $=68,74 \%$ & & & & & \\
\hline
\end{tabular}


Dentre os 64 haplótipos definidos com as sondas ISXac1, 2 e 3, apenas quatro deles foram identificados em mais de uma população. Os haplótipos números 14 e 21 foram encontrados nas populações "municípios de SP" e Presidente Prudente, enquanto os números 16 e 22 nas populações "municípios de SP", Novo Horizonte e Álvares Florence (Figura 1). Apesar de 23 haplótipos terem sido encontrados dentre os isolados de Presidente Prudente, observa-se que ocorreu a predominância do haplótipo 14 (42\% dos casos). Por outro lado, nas populações de Iacri, Urupês e Novo Horizonte, dois haplótipos foram majoritários, o que refletiu parcialmente em índices de diversidade genética de igual magnitude ou superiores aos de Presidente Prudente, apesar do menor número de haplótipos em cada uma destas três populações. Outro fato que contribuiu para o elevado polimorfismo observado foi a ocorrência de haplótipos diferentes entre as populações de isolados. Apenas Novo Horizonte e Álvares Florence compartilharam haplótipos, não tendo sido observadas diferenças nos índices de diversidade genética entre estas duas populações.

A menor similaridade (Jaccard) observada entre os 180 isolados, considerando as três sondas, foi de 0,42 , ocorrida entre CFBP 2525 e o isolado 12411 de Getulina. A máxima observada envolvendo o patótipo de Xac foi de 0,63 , na comparação com o isolado 13013 de Araras. O isolado sequenciado de Xac (306) apresentou-se mais similar aos isolados IBSBF 283 e IBSBF 438 de Araçatuba e Cajobí, respectivamente, com valor de 0,92. A mínima foi de 0,50, na comparação com CFBP 2525. Dentre todos os isolados de SP, as similaridades mínima e média foram de 0,59 e 0,84, respectivamente, a mínima tendo ocorrido entre os isolados 12411 e 12710, este último de Bebedouro. Dentre as populações estudadas, maior similaridade ocorreu entre Novo Horizonte e Álvares Florence, com média de 0,96, e a menor entre Iacri e Urupês, com média de 0,72 (Tabela 16). Dentre os 48 isolados que representam "municípios de SP" as similaridades mínima e média foram 0,59 e 0,87 , respectivamente.

Considerando as distâncias genéticas observadas, os haplótipos foram divididos, didaticamente, em grupos identificados pelas letras A a G (Figura 2). Os valores de bootstrap observados nas comparações destes grupos foram inferiores a dez, 

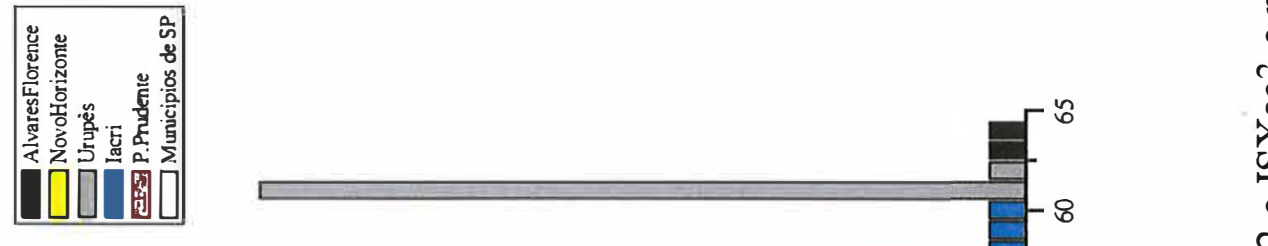

ปิ

ข్

?

-

$\rightarrow$ 8

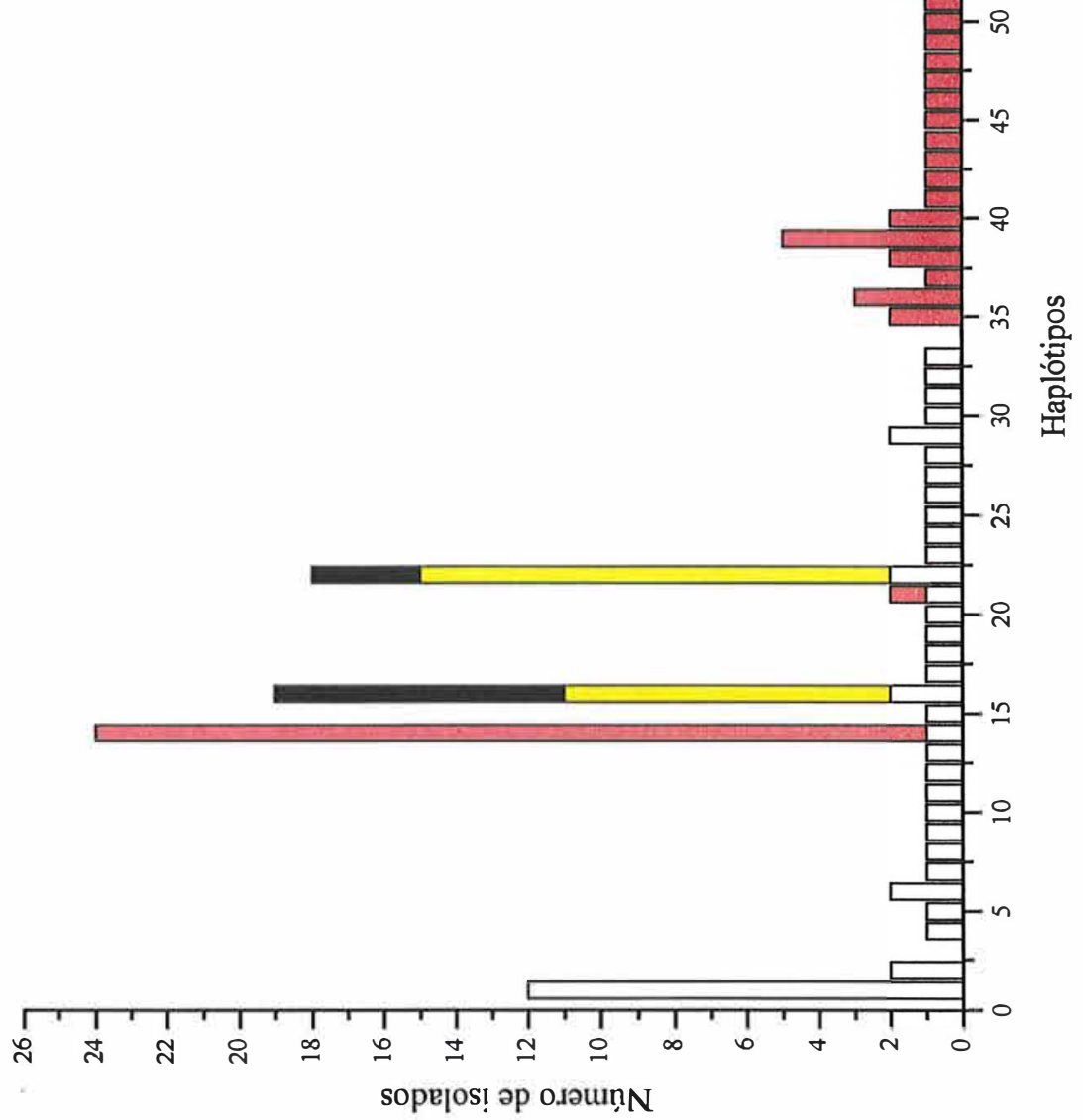

윤

芯

0

这

జ

ర్రુ

ర్త్రి

ป

ป

్ㅣㅇ

ช

0

n

정

胥

है

星

ఫ్

o

莺

\%

윯

记

葛

กิ

乨

है

氶

-

T)

్ㅣㅋ

모 


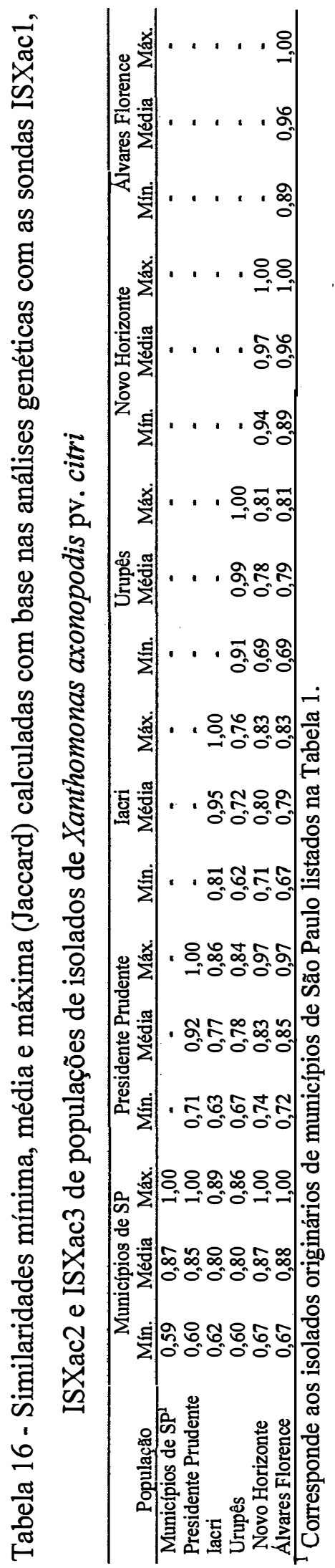




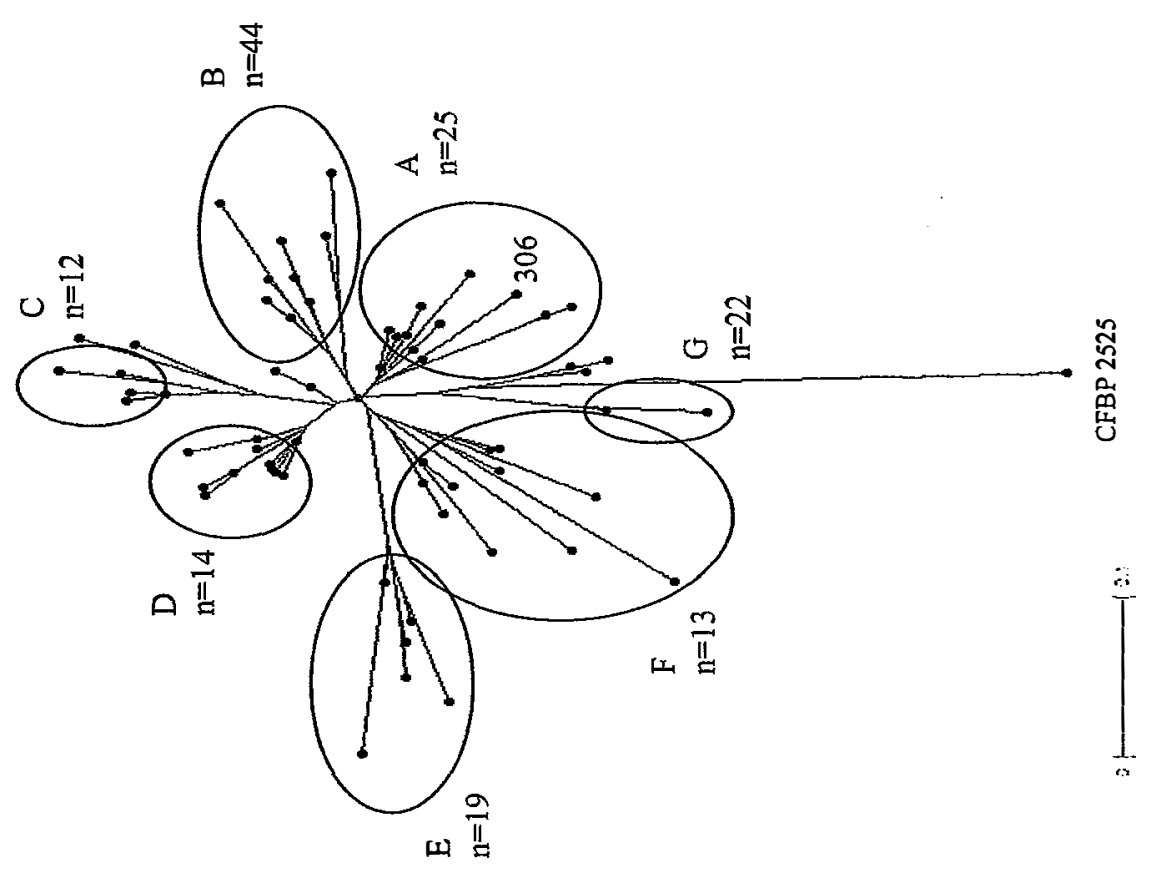

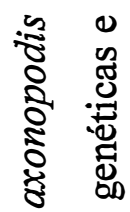

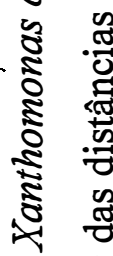

ष

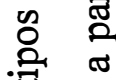

을 웅

ष

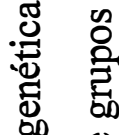

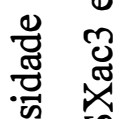

: 0

-

苞忘

宫

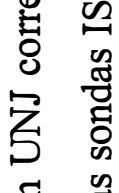

घ ป

¿ ठิ

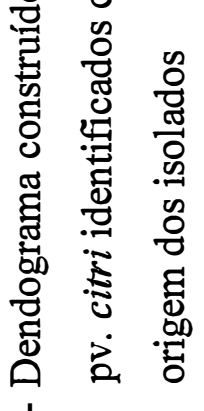

萜 
excetuando-se os grupos C, E e G, com valores de bootstrap de 37,57 e 80 , respectivamente. $\mathrm{O}$ grupo A é formado majoritariamente por isolados que compõem a população "municípios de SP", a qual contém os isolados mais antigos existentes, como IBSBF 314 de Araçatuba (1979) e IBSBF 220 e 221 de Monte Alto (1980), assim como isolados recentes (2001). Os haplótipos deste grupo A são: 1, 2, 3, 4, 9, 13, 17, 18, 23, 25, 29 e 33 (Figura 2 e Tabelas 5 e 6). Isolados distantes geograficamente estão dentro deste grupo (Ilha Solteira e Casa Branca, como exemplo, e o isolado 306, de Paranavaí, PR). Valores mais altos de bootstrap ocorreram dentro deste grupo para os isolados IBSBF 1474 e 12353 (bootstrap de 95), de Guzolândia e Jaci, respectivamente, 12988 e 13016 (bootstrap de 54), de Platina e Ourinhos, respectivamente, e IBSBF 314 e 1404 (bootstrap de 54), de Araçatuba e São João da Boa Vista, respectivamente.

O grupo B é formado pelos haplótipos 10,11,16, 20, 22, 44, 50, 63 e 64, os quais correspondem a isolados de municípios localizados nas regiões centro e oeste do Estado, como Cosmorama, Guaimbé, Iacanga, Reginópolis, Uru, Novo Horizonte e Álvares Florence. Todos os isolados dos pomares de Novo Horizonte e Álvares Florence estão neste grupo, e também o haplótipo 50, de Presidente Prudente. Valores mais altos de bootstrap foram observados entre os haplótipos 22 e 20 (bootstrap de 58), com isolados de Iacanga, Reginópolis, Novo Horizonte, Álvares Florence e Uru, e entre os haplótipos 10 e 11 (bootstrap de 51) de Novo Horizonte.

Os grupos C e D são formados exclusivamente por isolados de Presidente Prudente. Os haplótipos que compõem o grupo C são 39, 40, 45, 46 e 49, e o grupo D são 14, 36, 37, 38, 41, 42, 43, 48, 52, 53 e 54. Com exceção do haplótipo 14, isolado em um foco da doença em Presidente Prudente no ano de 2000, todos os demais haplótipos representam isolados coletados no mesmo pomar, no ano de 2003 (Tabelas 2 e 6). Valores altos de bootstrap somente ocorreram para os haplótipos 39, 40 e 45 (valor 69), e entre os haplótipos 46 e 49 (valor 56). Geneticamente mais próximos deste grupo estão os haplótipos números 26 e 30, de Ibitinga e Tarumã, respectivamente, e os de números 21 e 51, também de Presidente Prudente e Descalvado.

Todos isolados da população de Iacri estão no grupo $\mathrm{E}$, o qual é composto pelos haplótipos 56, 57, 58, 59 e 60 . Geneticamente mais próximo destes haplótipos está 
o isolado 12411, de Getulina. O grupo F é formado pelos haplótipos 5, 6, 7, 8, 12, 15, 24, 27, 31, 35 e 55, os quais correspondem a isolados dos municípios de Cândido Mota, Brotas, Santa Maria da Serra, Presidente Prudente, Bebedouro, Salto Grande, Ibitinga, Fernando Prestes, Lins e Presidente Bernardes. Os haplótipos números 12 e 55, de Presidente Prudente e Presidente Bernardes, apresentaram bootstrap de 64, o maior valor dentro deste grupo. Isolados antigos de São Paulo (IBSBF 338 e 349), ambos de 1981, também estão neste grupo. $\mathrm{O}$ último grupo definido foi $\mathrm{o} \mathrm{G}$, formado pelos haplótipos números 61 e 62 identificados em Urupês. Este grupo apresentou o mais alto valor de bootstrap (80) dentre todos os grupos formados.

A genotipagem dos isolados de Xac por FAFLP produziu resultados diferentes dos observados por RFLP. Com a combinação dos primers SacI + C e MspI + A, T, G e $\mathrm{C}$ apenas seis haplótipos foram identificados, quatro deles representados por apenas um isolado (Tabelas 5 e 6). Trinta e cinco, 54, 48 e 81 picos foram considerados com os primers SacI $+\mathrm{C} / \mathrm{MspI}+\mathrm{A}, \mathrm{T}, \mathrm{G}$ e C, respectivamente, totalizando 218 loci. $\mathrm{O}$ número de loci por isolado variou de 16 a $18 \mathrm{com} M s p I+\mathrm{A}, 26$ a 27 com MspI + T, $25 \mathrm{com}$ $M s p I+\mathrm{G}$ e 50 a 52 com MspI + C. As similaridades observadas (Jaccard) variaram de 0,96 a 0,99 , e a menor ocorreu entre os isolados 12826 e IBSBF 220 e também FDC 324. Não há correspondência entre os resultados obtidos com RFLP e FAFLP quanto aos haplótipos identificados. Haplótipos distintos e mais distantes geneticamente, como CFBP 2525, 306, 12411 e 12710, considerando os resultados de RFLP, apresentaram perfis idênticos por FAFLP. Enquanto a similaridade média, considerando os 180 isolados, foi de 0,84 com a técnica de RFLP, a mínima observada foi de $0,96 \mathrm{com}$ os resultados de FAFLP.

\subsection{Discussão}

Seqüências de inserção são elementos genéticos teoricamente instáveis e que potencialmente causam diferentes tipos de rearranjos como transposição, deleção, inversão e duplicação (Galas \& Chandler, 1989). No entanto, esses elementos têm sido úteis na determinação da estrutura genética de populações de patógenos humanos e 
vegetais (Adhikari et al., 1999; Gagnevin et al., 1997; Hermans et al., 1990; Leach et al., 1995; Nelson et al., 1994; Ochiai et al., 2000; Otal et al., 1991; Restrepo et al., 2000; Van Soolingen et al., 1991). Algumas das razões para isso são: a) o poder discriminante do uso destes elementos como sondas para Southern blot, permitindo a diferenciação de isolados bacterianos geneticamente próximos; b) o fato de encontrarem-se dispersos no genoma, em várias cópias, o que fornece múltiplas bandas para análises numéricas (Leach et al., 1992; Nelson et al., 1994); c) não estarem envolvidos diretamente na interação do patógeno com o hospedeiro, como genes avr e pth, o que fornece relativa "neutralidade" em estudos filogenéticos (Nelson et al., 1994); e d) possuírem relativa estabilidade quanto aos eventos de transposição, o que permite a identificação da relação entre isolados no tempo e no espaço (Van Soolingen et al., 1991).

Como observado em outros patossistemas envolvendo Xanthomonas, o uso de IS's como sondas para Southern blot permitiu a identificação de polimorfismo genético e a diferenciação de isolados de Xac. Os índices de diversidade genética obtidos variaram de 0,09 a 0,94 (Nei) e de 0,27 a 0,98 (Shannon) e mostraram-se dependentes das populações e sondas estudadas. A genotipagem de isolados de Xanthomonas oryzae pv. oryzae (Xoo) revelou índices de Shannon entre 0,74 a 0,98 com a genotipagem por rep-PCR e IS-PCR (Adhikari et al., 1999), valores estes similares aos aqui apresentados para Xac. Em outro estudo com Xoo foram observados índices de Nei entre 0,90 e 0,97 e, da mesma forma, os resultados variaram com as quatro sondas utilizadas (Nelson et al., 1994). Os índices de diversidade genética observados por estes autores não estiveram correlacionados com o número de bandas/haplótipo. De maneira similar, a sonda ISXac3 forneceu os menores número de haplótipos e índices de diversidade genética de Xac, apesar de ter apresentado o maior número de bandas em comparação com as sondas ISXacl e 2.

Ténicas moleculares baseadas em sondas hrp, perfil eletroforético após clivagem com enzimas de restrição, reassociação de DNA e pulsed-field gel electrophoresis, mostraram-se com limitado poder discriminatório na diferenciação de isolados de Xac (Egel et al., 1991; Gabriel et al., 1988; Hartung \& Civerolo, 1989; Hartung, 1992; Leite Júnior et al., 1994). Maiores dissimilaridades foram obtidas com 
BOX e ERIC-PCR, técnicas que permitiram a relativa caracterização de grupos genéticos e a separação parcial de isolados de Xac originários de diferentes países e regiões produtoras ou com patogenicidade diferenciada (Cubero \& Graham, 2002). As similaridades médias encontradas foram superiores a $85 \%$, calculadas pelo coeficiente de Dice. Com este mesmo coeficiente as similaridades mínima e média entre os 180 isolados genotipados com IS-RFLP foram de 59 e $91 \%$ (dados não apresentados). Para fins de comparação, a similaridade média entre o patótipo de Xac (CFBP 2525), originário da Nova Zelândia, e os demais isolados originários do Brasil, foi 70\%. Desta forma, a utilização das sondas ISXac1, 2 e 3 é a técnica de maior poder discriminante dentre as testadas com Xac, sendo, potencialmente, a melhor técnica na definição da estrutura genética de populações desse patógeno e na identificação de origem de focos.

Os resultados obtidos com FAFLP diferiram da genotipagem realizada com ISRFLP e apenas seis haplótipos foram identificados. Isolados representados por haplótipos dissimilares por IS-RFLP apresentaram o mesmo perfil haplotípico com FAFLP e o único grupo de isolados discriminado por ambas técnicas foi o originário de Urupês. Baixa correlação entre as similaridades encontradas com RFLP e AFLP também foi observada para Xanthomonas axonopodis pv. manihotis (Restrepo et al., 2000). Esses autores observaram dendogramas mais robustos quando gerados com os dados de AFLP, tornando esta técnica mais propícia para estudos filogenéticos (Nelson et al., 1994; Restrepo et al., 2000). Da mesma forma, apesar da baixa dissimilaridade observada com Xac, maiores bootstraps ocorreram com os dados de FAFLP (dados não mostrados). Mesmo isolados de origem diferentes como o patótipo de Xac (CFBP 2525) e os demais originários do Brasil apresentaram similaridade média de $96 \%$ (Jaccard). Os resultados obtidos com uma coleção mundial de Xac por BOX e ERIC-PCR (Cubero \& Graham, 2002) e os aqui apresentados com FAFLP sugerem uma baixa variabilidade genética, em termos filogenéticos, de isolados deste patógeno. Embora a coleção de isolados estudada tenha apresentado uma relativa diversidade genética com RFLP, esta técnica é mais adequada na determinação da estrutura populacional de um patógeno, enquanto estudos filogenéticos e evolucionários exigem marcadores moleculares com maior neutralidade, como os gerados por AFLP (Restrepo et al., 2000; Vos et al., 1995). De fato, a 
comparação das técnicas AFLP e rep-PCR com a homologia DNA-DNA, utilizando uma coleção de espécies e patovares do gênero Xanthomonas, revelou a utilidade destas duas técnicas na determinação da diversidade taxonômica e a estrutura filogenética de isolados bacterianos (Rademaker et al., 2000).

A distribuição de haplótipos de patovares de Xanthomonas baseada na técnica de RFLP com sondas como IS's e genes avr e pth, tem fornecido uma adequada quantificação da diversidade genética da população do patógeno, tendo revelado, pelo menos parcialmente, alguns fatores envolvidos na adaptação do patógeno ao hospedeiro/ambiente e permitido o estabelecimento de hipóteses baseadas na ecologia do patossistema (Adhikari et al., 1999; Gagnevin et al., 1997; Nelson et al., 1994; Ochiai et al., 2000; Restrepo et al., 2000). As sondas ISXacl, 2 e 3 de Xac utilizadas no presente estudo permitiram uma relativa separação dos isolados, baseada nas populações estudadas e na origem geográfica destes, apesar dos baixos valores de bootstrap obtidos. Isto ocorreu em razão do pequeno número de loci polimórficos identificados, e também por esta razão, dendogramas mais robustos foram obtidos com a sonda ISXac3 e também com FAFLP. De modo a visualizar o máximo de diferenciação entre os isolados testados optou-se pela utilização dos dados combinados das três sondas. Os 48 isolados de São Paulo, com datas de isolamento entre 1979 e 2001, distribuiram-se basicamente nos grupos A, B e F, enquanto os isolados de diferentes pomares, cada um originado de uma planta doente, agruparam-se distintamente nos grupos B, C/D, E e G (Figura 2). Em razão da maioria dos isolados possuir o mesmo hospedeiro e serem originários de anos recentes, não foi possível o estudo da interação destes dois fatores com a diversidade haplotípica identificada.

O histórico do cancro cítrico no Estado de São Paulo, e os respectivos históricos da doença em cada pomar avaliado, permitem o estabelecimento de algumas hipóteses quanto a estrutura populacional do patógeno. O primeiro relato do cancro cítrico no Brasil deu-se no município de Presidente Prudente, em 1957 (Amaral, 1957; Bittancourt, 1957). Apesar de uma campanha de erradicação da doença ter sido iniciada neste mesmo ano, e estar em atividade até os dias atuais, novos focos da doença foram sendo encontrados desde então e a doença encontra-se presente em diversas localidades 
de São Paulo e também em outros estados do país (Amaral, 1957; Barbosa et al., 2001; Gimenes-Fernandes et al., 2000; Nascimento et al., 2003; Porto et al., 1981). Na população "municípios de SP" há isolados com origem em municípios localizados nas regiões norte, sul, centro e noroeste do Estado, e que possuem ou não histórico da doença (Tabela 1). Essa população foi a que apresentou os maiores níveis de diversidade genética e haplotípica dentre as populações estudadas, o que pode ser em razão das diferentes origens, distâncias geográficas e históricos da doença em cada localidade. A migração do patógeno a longas distâncias, provavelmente por material vegetal infectado, é uma hipótese razoável diante a identificação de haplótipos idênticos em municípios distantes (Graham et al., 2004). O índice de diversidade genética de Nei mensura a probabilidade de dois isolados, coletados ao acaso, apresentarem perfis genéticos distintos (Leach et al., 1992). A coleta de novos isolados, em cinco diferentes municípios - Presidente Prudente, Iacri, Urupês, Novo Horizonte e Álvares Florence resultou na identificação de novos haplótipos. Isto, aliado aos índices de diversidade genética observados, permite afirmar que a genotipagem de novos isolados provavelmente resultará na identificação de novos haplótipos por IS-RFLP.

Levantamentos amostrais da doença em São Paulo têm revelado que as regiões citrícolas centro e noroeste são as que possuem as maiores incidências da doença (Barbosa et al., 2001). Estas regiões estão representadas nas populações estudadas de Xac. Os municípios de Presidente Prudente e Iacri localizam-se na região oeste do estado, Novo Horizonte e Urupês na região central, e Álvares Florence na região noroeste. Todos estes municípios, excetuando-se Urupês, possuem histórico de ocorrência de cancro cítrico, em razão de plantas e pomares infectados serem freqüentemente encontrados. Excetuando-se o pomar de Presidente Prudente, todos os demais eram pomares comerciais de cítricos e as plantas doentes foram originadas da infecção natural pelo patógeno. Desta forma, os maiores índices de diversidade genética observados nestas populações podem ter ocorrido em razão dos períodos relativamente mais longos de contato entre patógeno e hospedeiro. Históricos mais longos permitem mais facilmente a observação de eventos geradores de variabilidade genética na 
população do patógeno, como a ocorrência de mutações ou a migração de haplótipos entre localidades.

O município de Presidente Prudente nunca foi considerado livre do patógeno. Além disso, a população de isolados coletada nesse município tem como origem plantas doentes presentes numa extinta estação de pesquisas em cancro cítrico. As atividades desse centro de pesquisa foram iniciadas na década de oitenta, quando da inoculação das primeiras plantas, e desde então plantas doentes sempre estiveram presentes neste área. A população desse município apresentou a maior diversidade (índice de Nei), dentre as cinco estudadas, caracterizadas por isolados do mesmo pomar, no que concerne à freqüência relativa de haplótipos. Em razão das sondas utilizadas corresponderem a cópias de IS's, parte da diversidade genética observada provavelmente deva-se aos eventos de transposição destes genes no genoma do patógeno (Leach et al., 1995; Nelson et al., 1994; Van Soolingen et al., 1991). As menores dissimilaridades observadas entre isolados originados dos mesmos pomares provavelmente ocorreram em razão destes eventos de transposição. A variabilidade genética encontrada ocorreu, em grande parte, devido a diferenças no número e na posição de poucos loci. É razoável imaginar que, embora a população do patógeno esteja em constante modificação devido as transposições dos IS's, a identificação dos diferentes perfis haplotípicos e a divisão da população em grupos de acordo com a origem geográfica, permitem o estudo da estrutura da população do patógeno. $\mathrm{O}$ agrupamento de haplótipos que representam isolados originados do mesmo pomar é um indício desta possibilidade (Figura 2).

A população de Presidente Prudente também foi a que apresentou o maior número de haplótipos presentes em grupos distintos ( $\mathrm{B}, \mathrm{C}, \mathrm{D}$ e F, Figura 2), o que revela parcialmente sua alta diversidade genética. Infelizmente não há o isolado utilizado, ou informações quanto a sua origem, na inoculação da área experimental de Presidente Prudente. Da mesma forma, não há isolados coletados quando do aparecimento da doença em São Paulo ou anteriores a 1979. Estes fatos impedem uma adequada comparação dos haplótipos no que concerne a evolução da população do patógeno desde sua introdução. O perfil majoritário encontrado em São Paulo não está entre os haplótipos identificados em Presidente Prudente, origem da doença no Brasil. Mesmo as 
distâncias genéticas calculadas resultaram no agrupamento da população de Presidente Prudente distintamente da que contém este haplótipo mais comum. A coleta e genotipagem de novos isolados faz-se necessária e somente desta forma poderá traçar-se a correspondência entre os haplótipos identificados e quais os fatores envolvidos na geração dessa varibilidade genética.

Não há ainda informações referentes à estabilidade dos perfis genéticos de Xac obtidos com base em IS-RFLP. Uma vez identificada sua utilidade na deteç̧ão de variabilidade genética, aqui apresentada, novos estudos baseados na avaliação in vitro $\mathrm{e}$ in vivo da estabilidade de diferentes perfis genéticos permitirão uma adequada $\mathrm{e}$ necessária avaliação dessa técnica na genotipagem de isolados deste patógeno. Resultados obtidos com outros patossistemas indicam, que embora instáveis, genes IS possuem relativa estabilidade a ponto de poderem ser utilizados como ferramentas na identificação da estrutura populacional de patógenos. O fato de isolados de Xac, com datas de isolamento em 1981, terem apresentado o mesmo perfil haplotípico de isolados de 2001, é uma indicação da relativa estabilidade destes genes. A geração e avaliação de um número maior de sondas baseadas em genes IS, para utilização em Southern blot, ou de primers para utilização como IS-PCR, também devem ser priorizadas, pois somente desta forma será possível a obtenção de dendogramas mais robustos, e a divisão da população em grupos distintos, com resultados mais confiáveis. Uma das melhores alternativas constitui-se na utilização da técnica denominada LM-PCR (ligationmediated polymerase chain reaction) a qual apresentou boa correspondência com resultados obtidos com IS-RFLP para M. tuberculosis, e possui as vantagens de ser mais rápida e menos onerosa na geração dos perfis genéticos (Palittapongarnpim et al., 1993). 


\section{CONCLUSÕES GERAIS}

As escalas diagramáticas desenvolvidas para a avaliação da severidade do cancro cítrico em folhas permitiram avaliações suficientemente acuradas e precisas e o treinamento dos avaliadores aumentou a precisão das estimativas. Objetivando uma adequada quantificação da severidade do cancro cítrico, sugere-se, na avaliação, a escolha de ramos em diferentes lados da mesma planta e a quantificação da doença nas folhas desses ramos.

A propagação do cancro cítrico exclusivamente por adultos de $P$. citrella não é um evento comum na natureza e, por essa razão, não possui importância epidemiológica. As injúrias provocadas pelas fases imaturas do inseto permitem maiores incidências da doença, com reflexos na área sob a curva de progresso da doença ( $A U D P C)$, e as plantas infestadas com a larva minadora e infectadas pelo patógeno apresentam sintomas da doença mais rapidamente, em comparação com infecções ocorridas na ausência de ferimentos. A redução no período de incubação provoca um maior número de ciclos da doença, com conseqüências epidemiológicas relevantes. Os tecídos doentes apresentam maiores severidades, e, consequentemente, maiores populações bacterianas encontramse passíveis de disseminação para a mesma planta e plantas vizinhas. As injúrias provocadas pelo inseto demoram a cicatrizar e permitem infecções por períodos mais longos, de vários dias, enquanto ferimentos mecânicos cicatrizam em aproximadamente três dias. As mudanças nos componentes monocíclicos da doença provocadas pela infestação da larva minadora explicam o aumento da incidência do cancro cítrico a partir de 1996 e justificam o maior rigor adotado no controle da doença.

Sob condições naturais de infecção as plantas doentes mostram-se agregadas, muito embora o aumento da incidência da doença ocorra não apenas pelo incremento de 
plantas doentes dentro do foco, mas também pelo incremento no número de focos unitários. A ocorrência de focos secundários a longas distâncias do foco principal (até 177 metros no presente estudo) é freqüentemente observada sob condições naturais de epidemia, o que implica em maior dificuldade na execução da erradicação da doença.

Como observado em outros patossistemas envolvendo Xanthomonas, o uso de IS's como sondas para Southern blot permitiu a identificação de polimorfismo genético e a diferenciação de isolados de Xanthomonas axonopodis pv. citri (Xac). Os índices de diversidade genética obtidos variaram de 0,09 a 0,94 (Nei) e de 0,27 a 0,98 (Shannon) e mostraram-se dependentes das populações e sondas estudadas. A utilização das sondas ISXacl, 2 e 3 é a técnica de maior poder discriminante dentre as já testadas com Xac, sendo, potencialmente, a melhor técnica na definição da estrutura genética de populações desse patógeno e na identificação de origem de focos. Os resultados obtidos com FAFLP diferiram da genotipagem realizada com IS-RFLP. As sondas ISXacl, 2 e 3 permitiram uma relativa separação dos isolados, baseada nas populações estudadas e na origem geográfica destes, apesar dos baixos valores de bootstrap obtidos. 
ANEXOS 


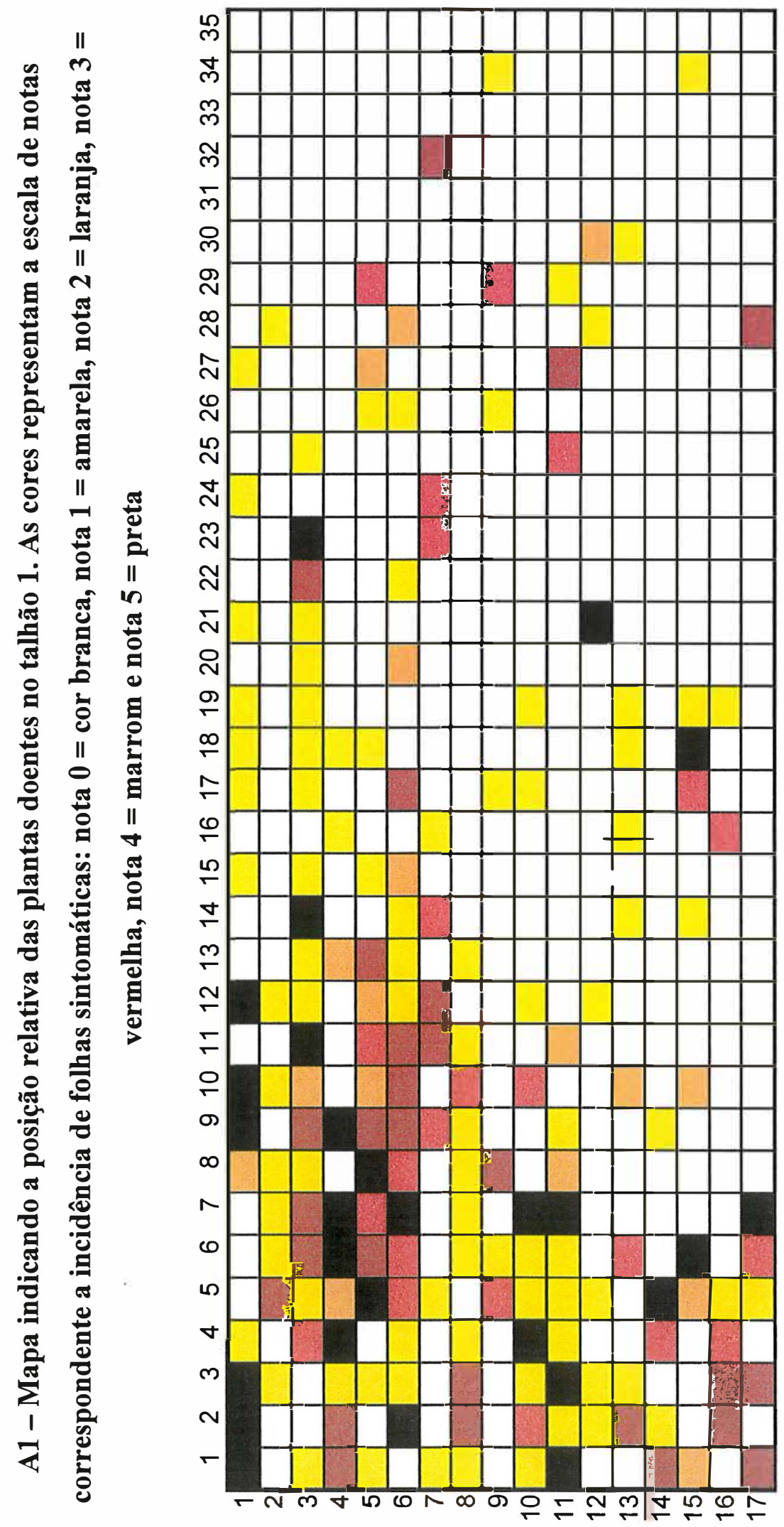




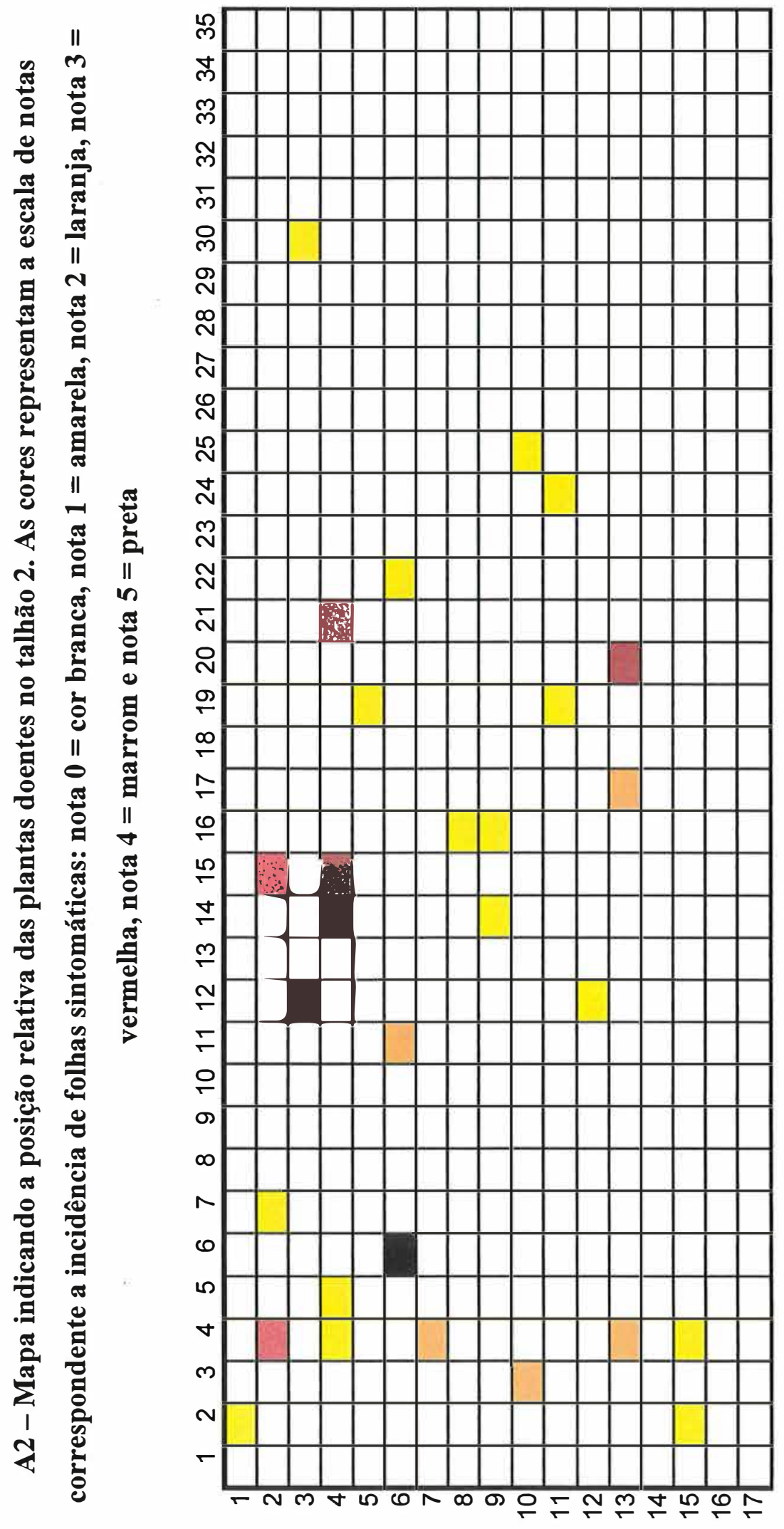




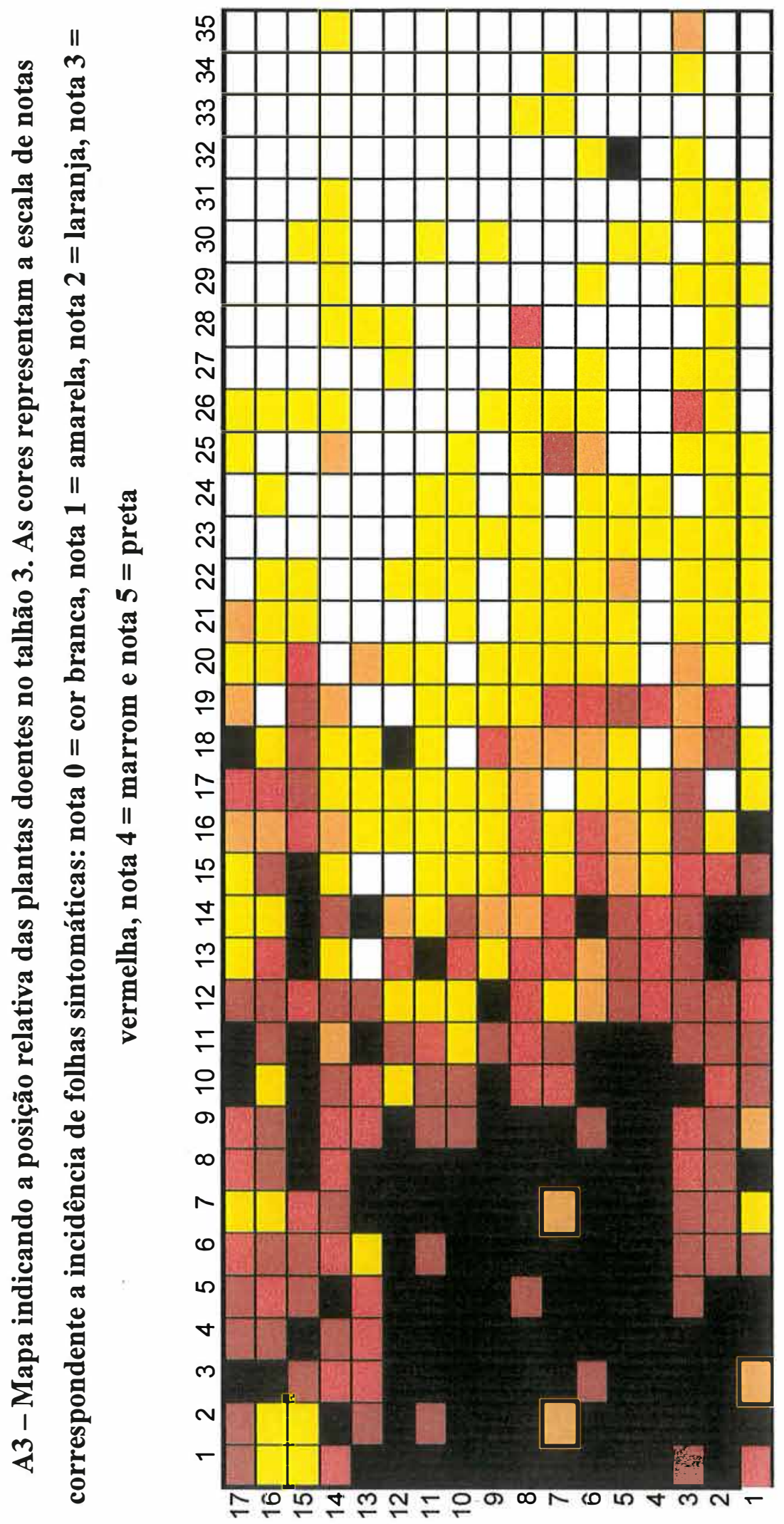




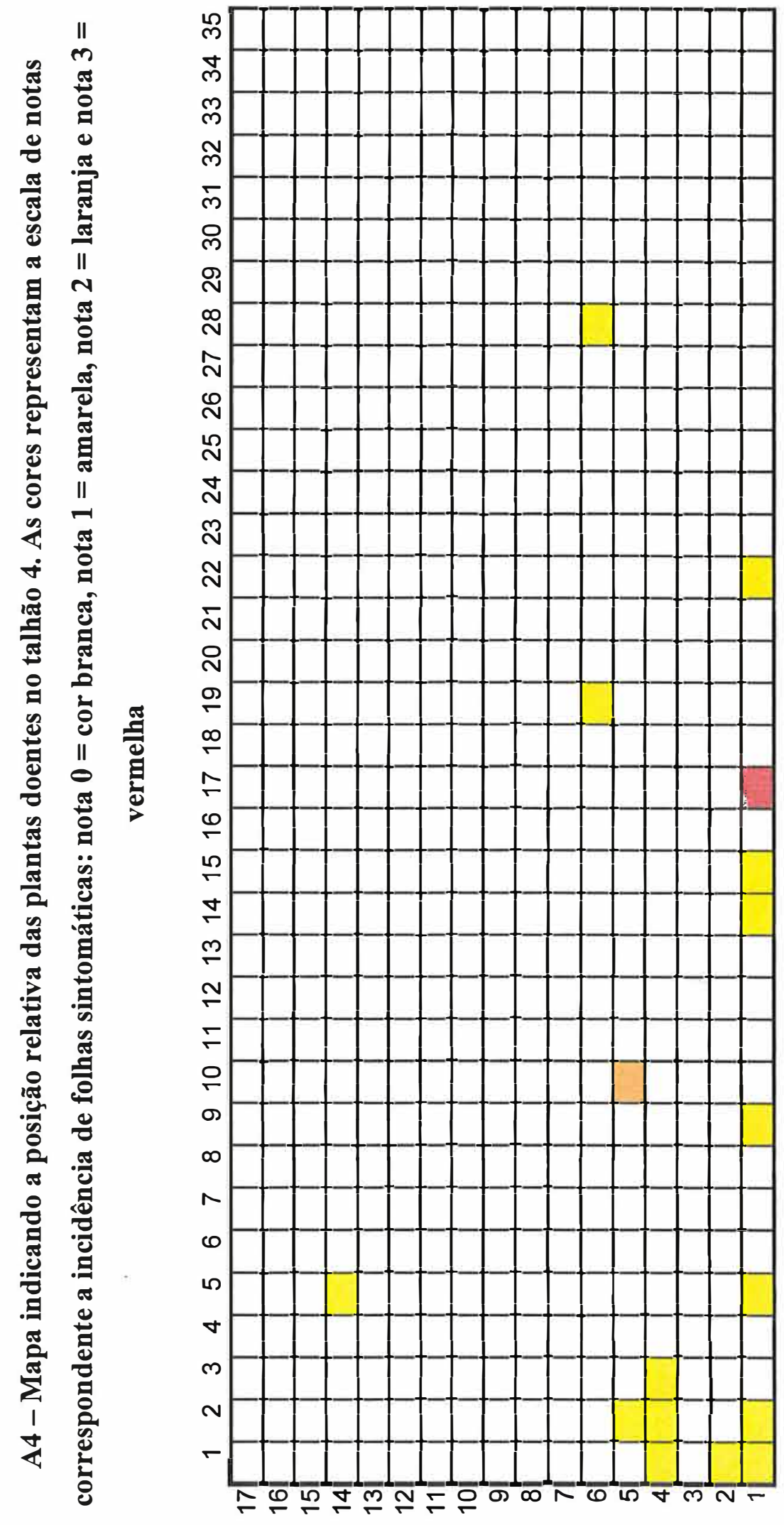




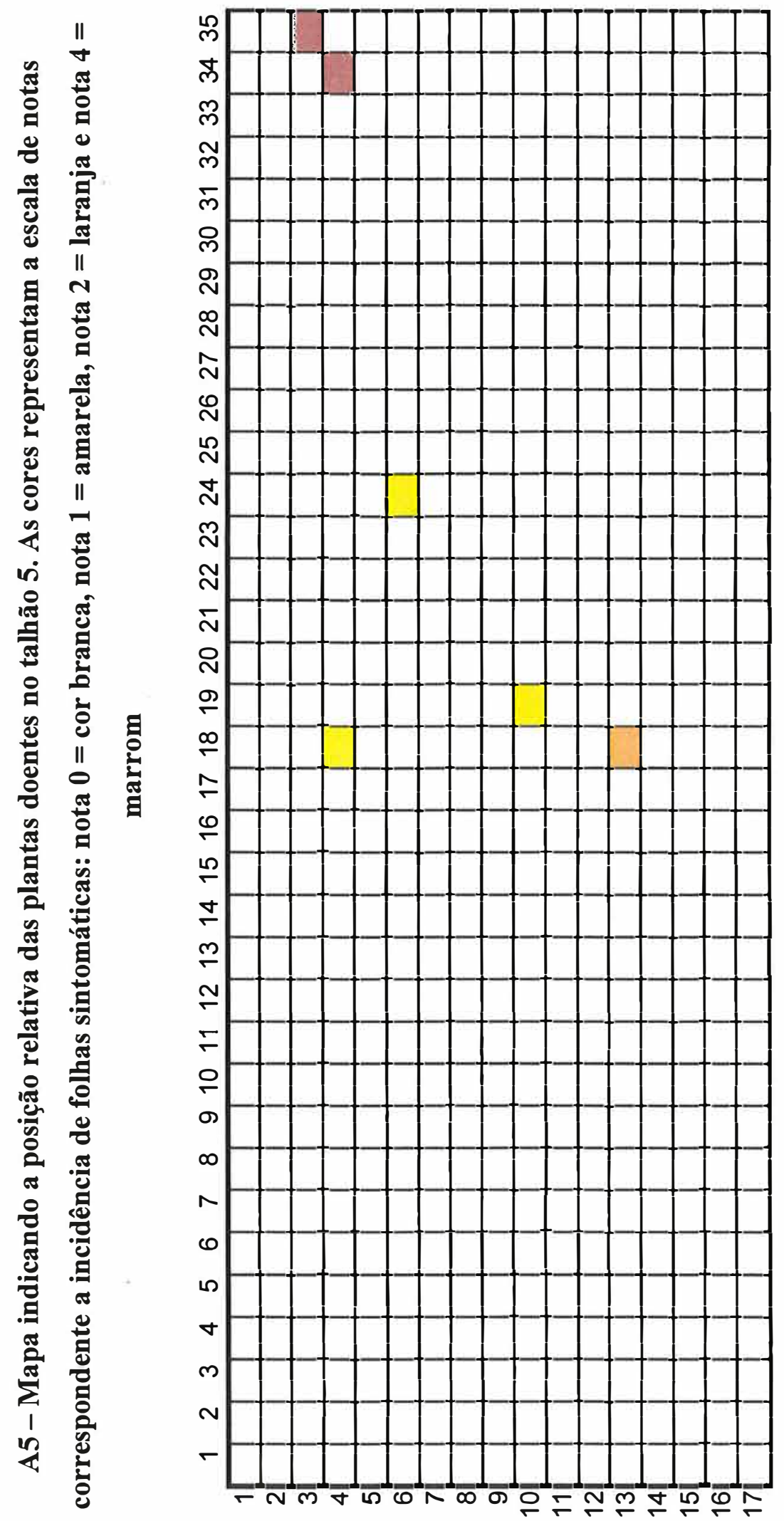




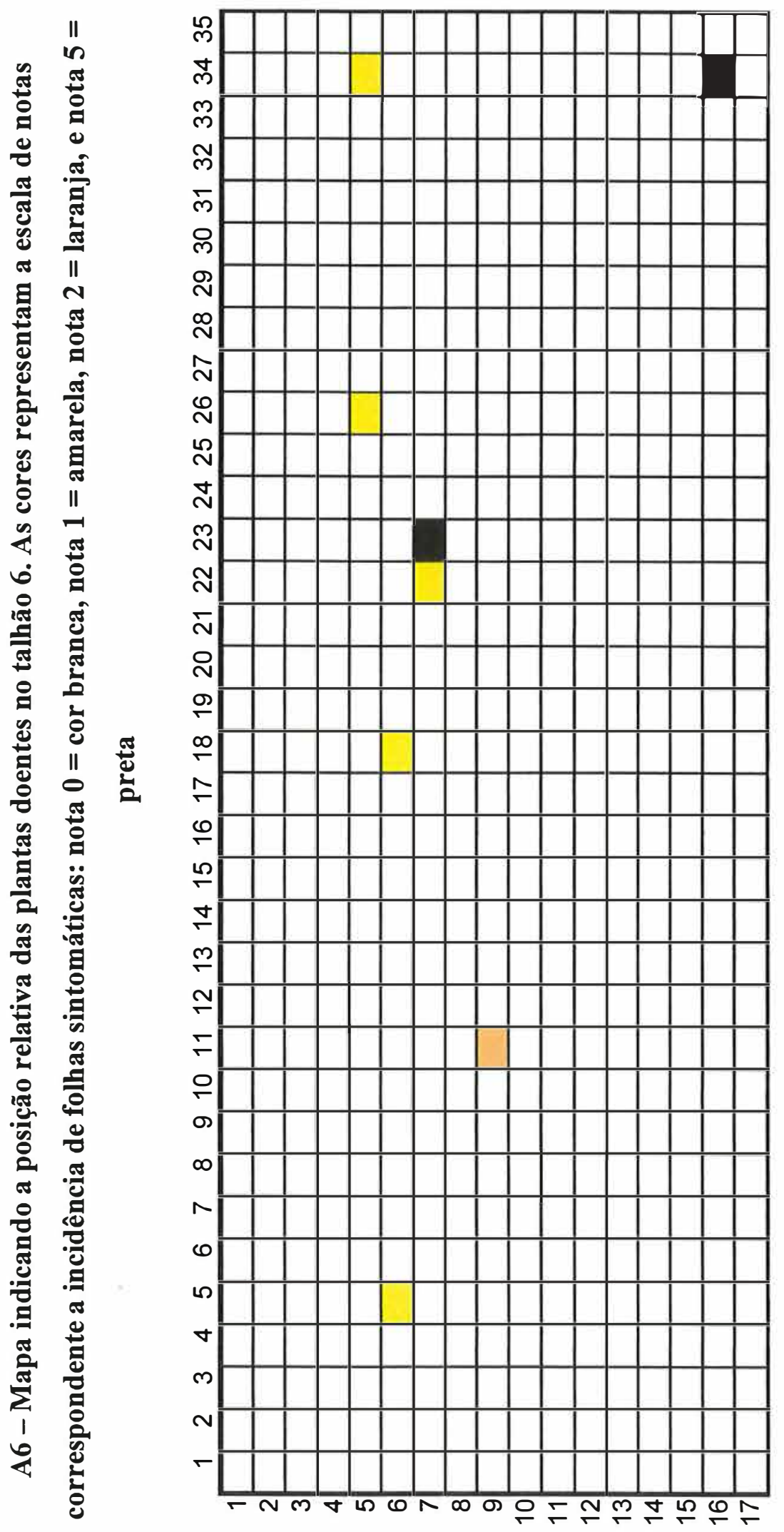




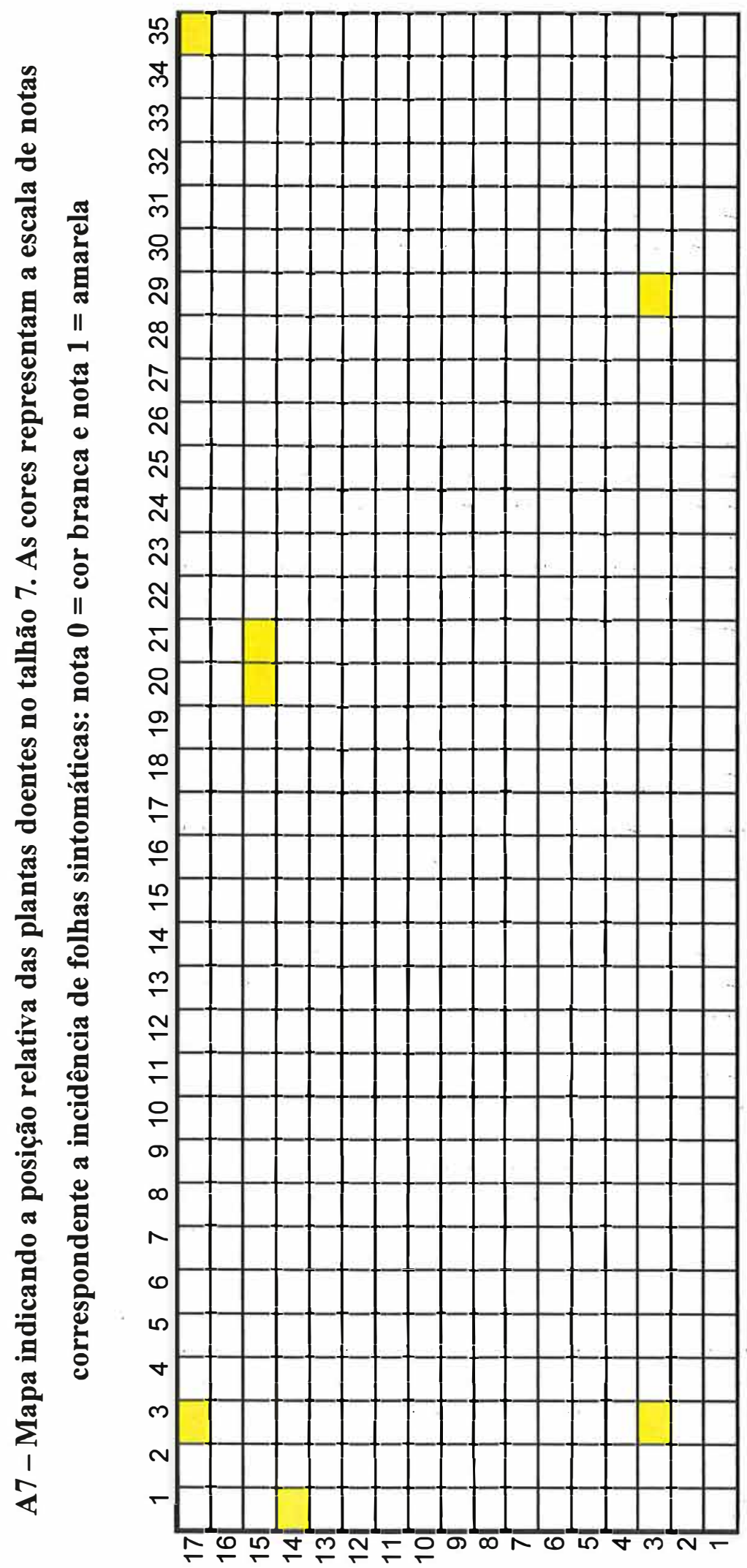




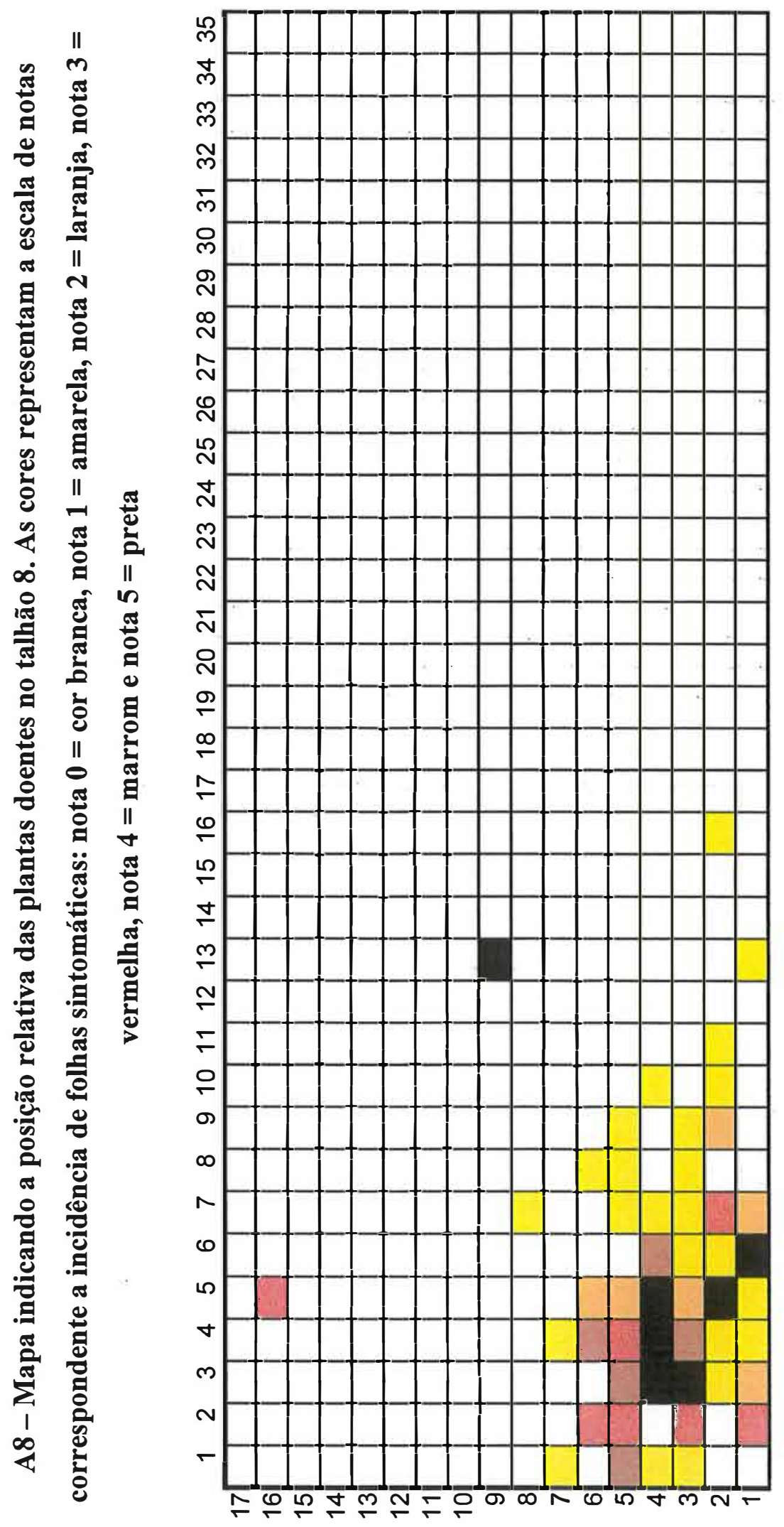




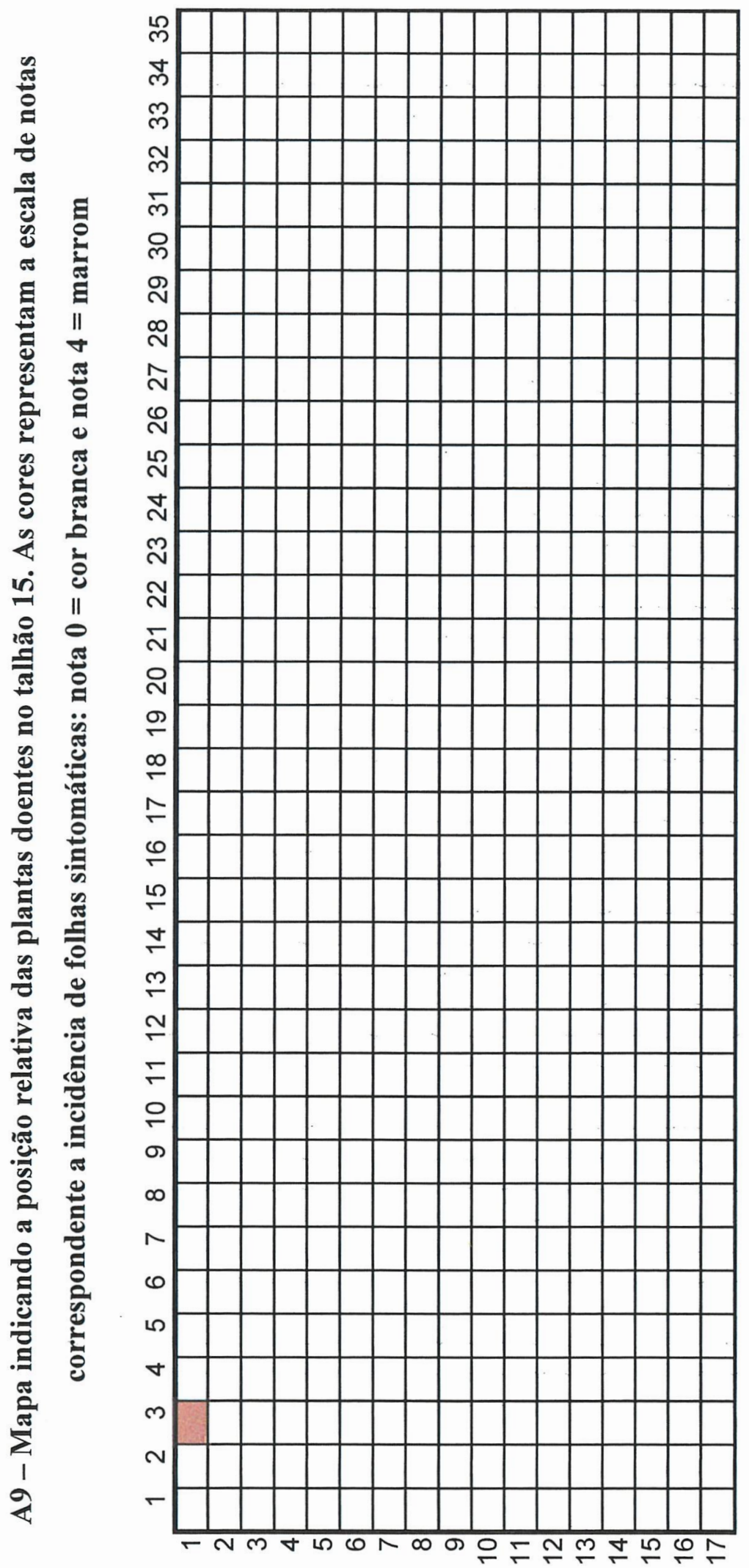




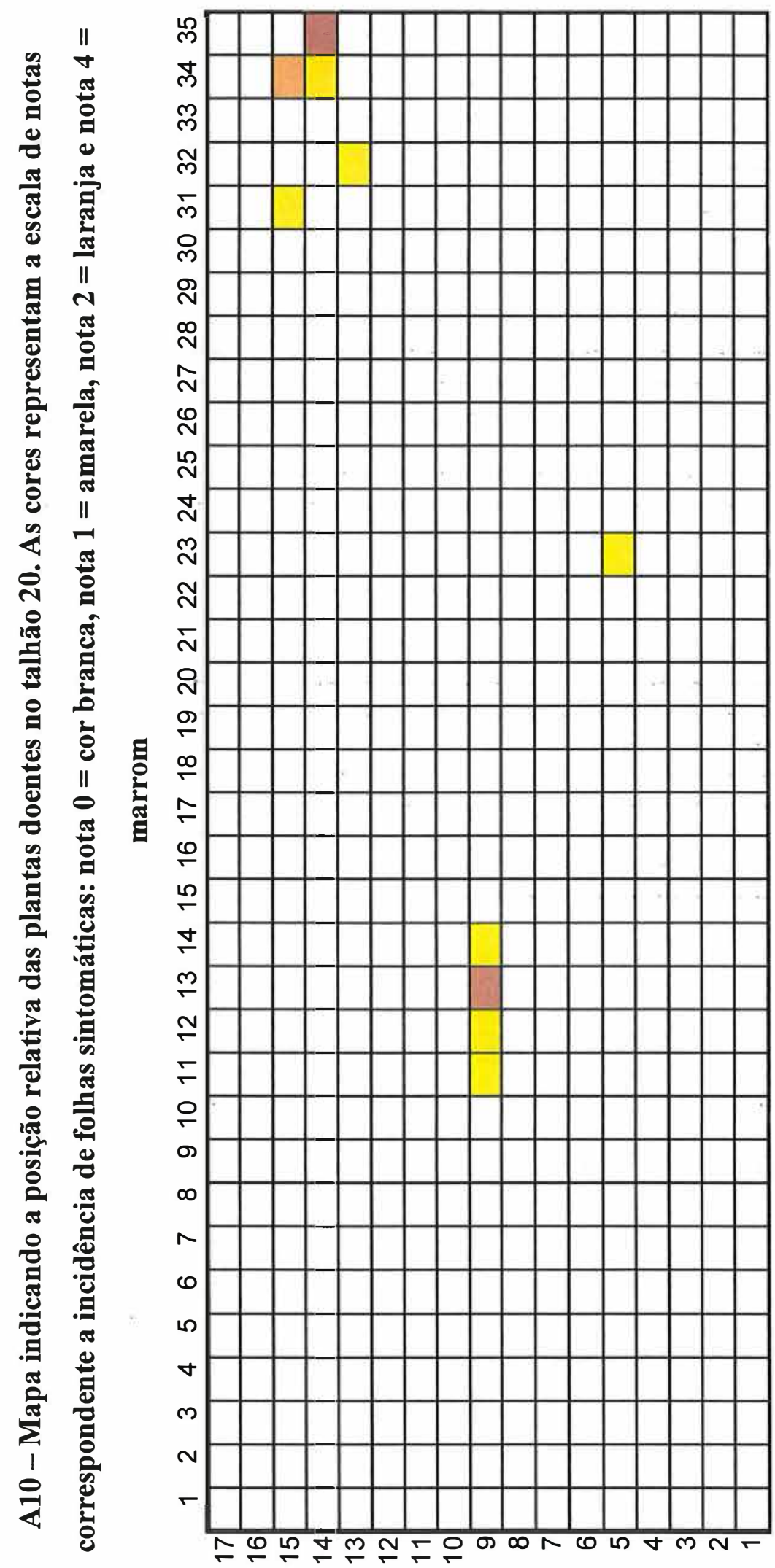




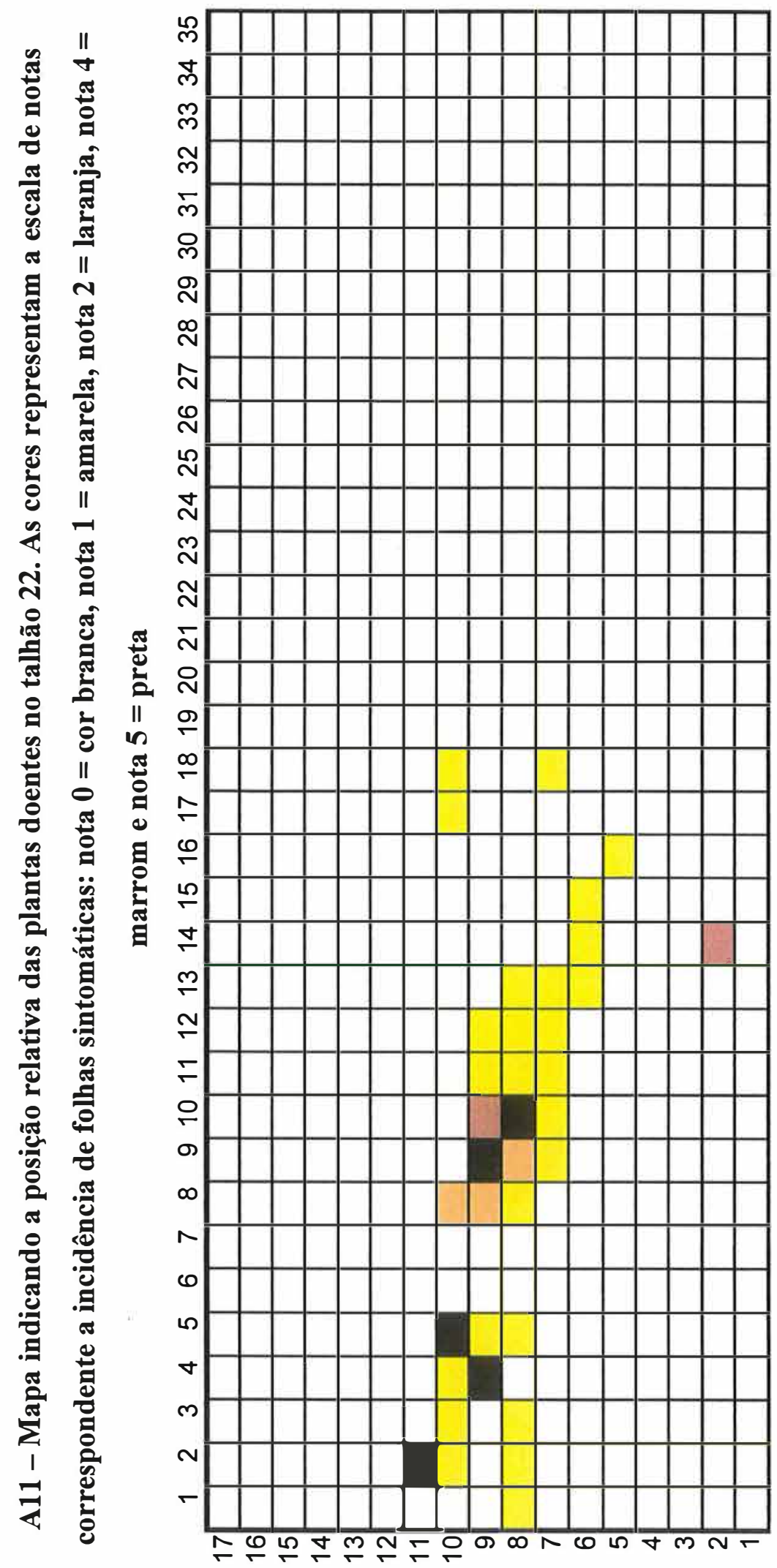




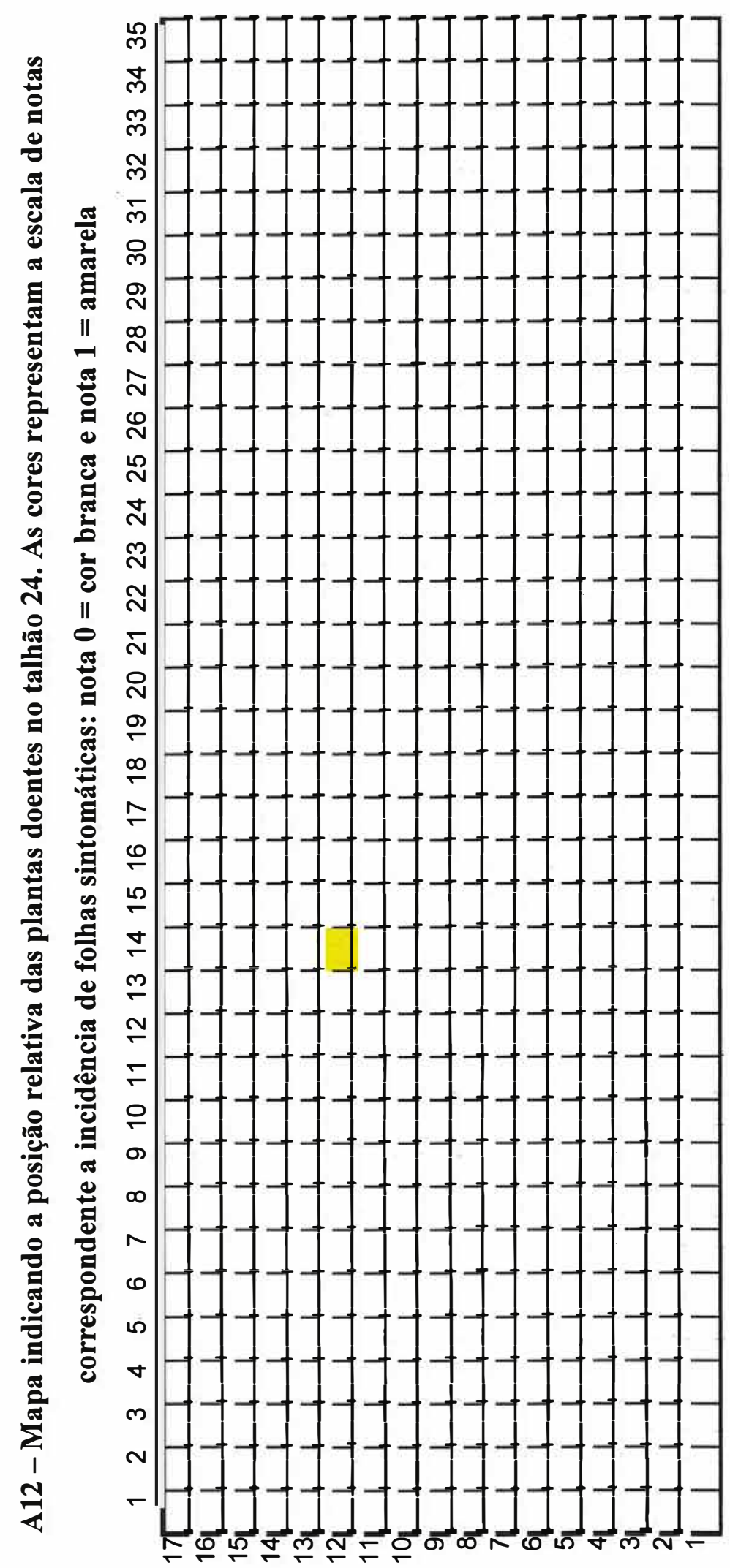




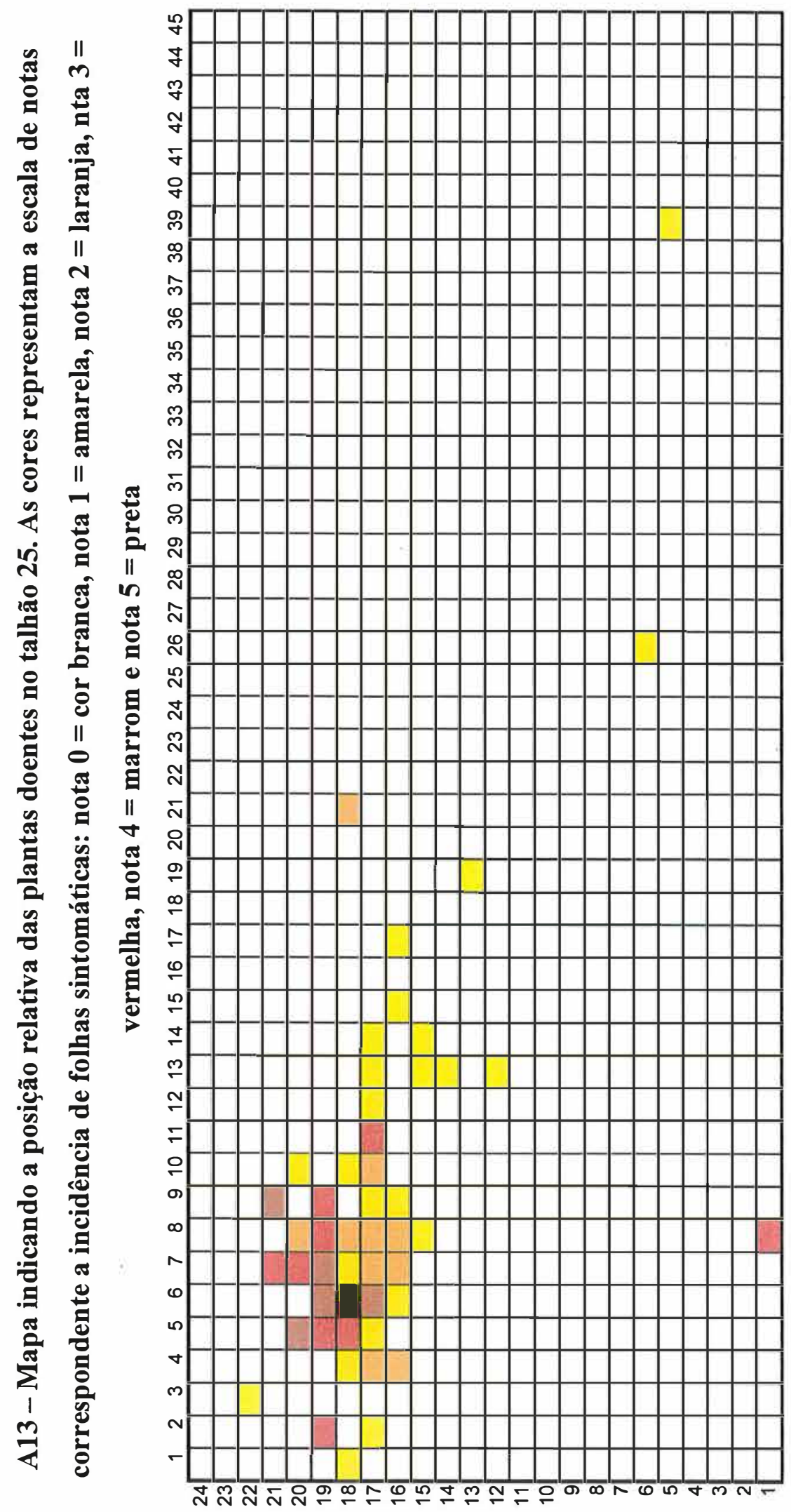




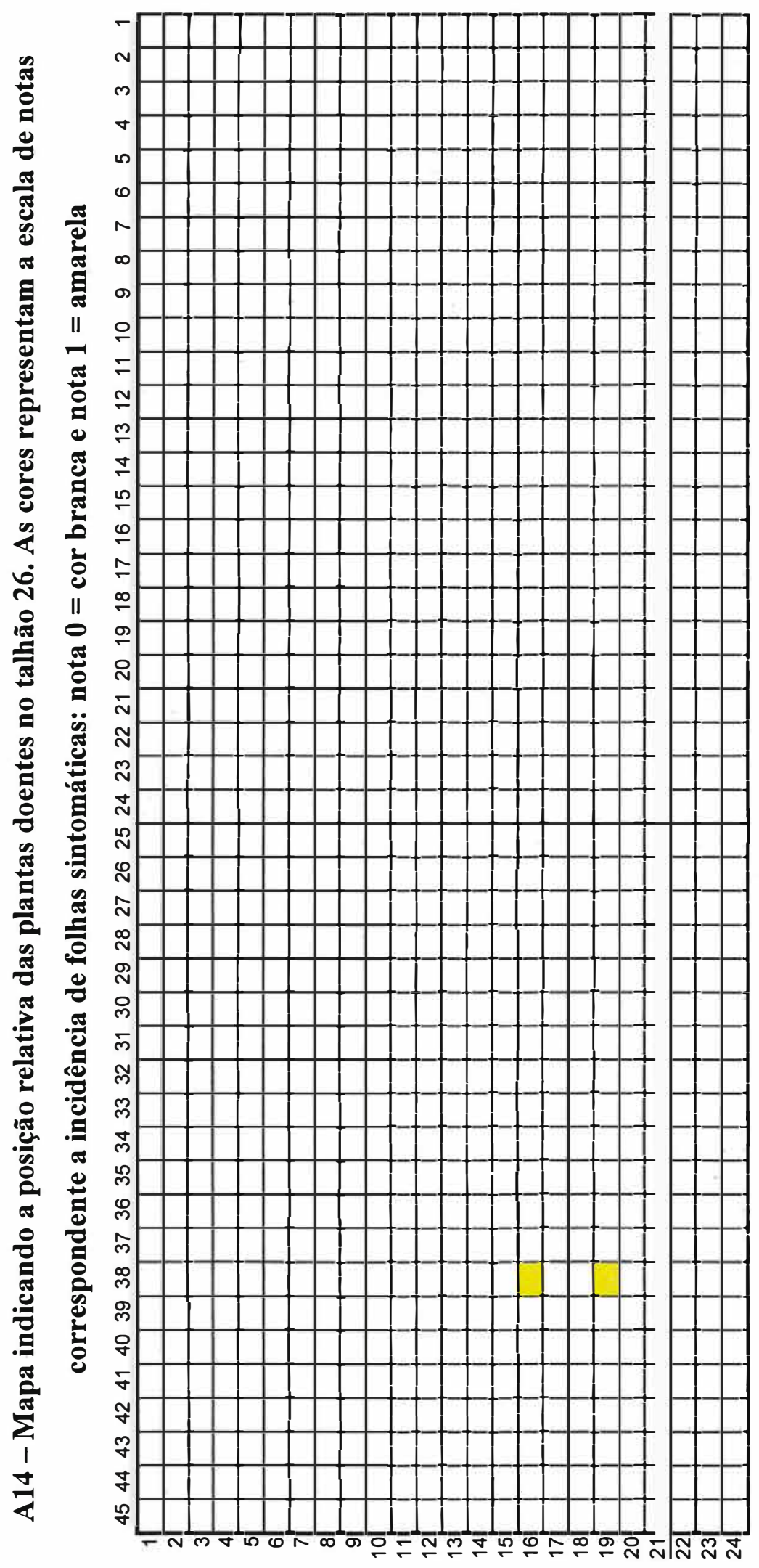




\section{REFERÊNCIAS BIBLIOGRÁFICAS}

ACHOR, D.S.; BROWNING, H.W.; ALBRIGO L.G. Anatomical and histological modifications in citrus leaves caused by larval feeding of citrus leafminer (Phyllocnistis citrella Staint). In: INTERNATIONAL CONFERENCE ON Citrus leafminer, Orlando, 1996. Proceedings. Orlando: University of Florida, 1996. p.69.

ADHIKARI, T.B.; MEW, T.W.; LEACH, J.E. Genotypic and pathotypic diversity in Xanthomonas oryzae pv. oryzae in Nepal. Phytopathology, v.89, p.687-694, 1999.

AMARAL, S.F. Providências para a erradicação do cancro cítrico. O Biológico, v.23, p.112-123, 1957.

AMORIM, L. Avaliação de doenças. In: BERGAMIN FILHO, A.; KIMATI, H.; AMORIM, L. (Ed.) Manual de Fitopatologia. São Paulo: Editora Ceres, 1995. p.647-671.

AUSUBEL, F.M.; BRENT, R.; KINGSTON, R.E.; MOORE, D.D.; SEIDMAN, J.G.; SMITH, J.A.; STRUHL, K. Current protocols in molecular biology. New York: Wiley. 1995.

BADAWY, A. The morfology and biology of Phyllocnistis citrella Stainton, a citrus leaf-miner in the Sudan. Bulletin of Society Entomological Egypte, v.51, p.95$103,1967$.

BARBOSA, J.C.; GIMENES-FERNANDES, N.; MASSARI, C.A.; AYRES, A.J. Incidência e distribuição de cancro cítrico em pomares comerciais do Estado de São Paulo e sul do Triângulo Mineiro. Summa Phytopathologica, v.27, p.30-35, 2001. 
BAUER, J.; ANDERSEN, S.B. Stability of insertion sequence IS1245, marker for differentiation of Mycobacterium avium strains. Journal of Clinical Microbiology, v.37, p.442-444, 1999.

BEATTIE, G.A.; LINDOW, S.E. The secret life of foliar bacterial pathogens on leaves. Annual Review of Phytopathology, v.33, p.145-172, 1995.

BERGAMIN FILHO, A.; AMORIM, L.; LARANJEIRA, F.F.; GOTTWALD, T.R. Epidemiology of citrus canker in Brazil with and without the asian citrus leafminer. In: INTERNATIONAL CITRUS CANKER RESEARCH WORKSHOP, Fort Pierce, 2000. http://www.doacs.state.fl.us/canker; Proceedings, Fort Pierce, 2000.

BITANCOURT, A.A. O cancro cítrico. O Biológico, v.23, p.101-111, 1957.

BRENNER, D.J.; MCWHORTER, A.C.; KNUTSON, J.K.; STEIGERWALT, A.G. Escherichia vulneris: a new species of Enterobacteriaceae associated with human woungs. Journal of Clinical Microbiology, v.15, p.1133-1140, 1982.

BUTCHER, P.D.; HUTCHINSON, N.A.; DORAN, T.J.; DALE, J.W. The application of molecular techniques to the diagnosis and epidemiology of mycobacterial diseases. Journal of Applied Bacteriology, v.81, p.553-571, 1996.

CAMPBELL, C.L.; MADDEN, L.V. Introduction to Plant Disease Epidemiology. New York. John Wiley, 1990. 532p.

CHAGAS, M.C.M. Phyllocnistis citrella Stainton, 1856 (Lepidoptera: Gracillariidae): bioecologia e relação com o cancro cítrico. Piracicaba, 1999, 67p. Tese (Doutorado) - Escola Superior de Agricultura “Luiz de Queiroz”, Universidade de São Paulo.

CHAGAS, M.C.M.; PARRA, J.R.P. Phyllocnistis citrella Stainton (Lepidoptera: Gracillariidae): técnica de criação e biologia em diferentes temperaturas. Anais da Sociedade Entomológica do Brasil, v.29, p.227-235, 2000. 
CHAGAS, M.C.M.; PARRA， J.R.P.; NAMEKATA， T.; HARTUNG， J.S.; YAMAMOTO, P.T. Phyllocnistis citrella Stainton (Lepidoptera: Gracillariidae) and its relationship with the citrus canker bacterium Xanthomonas axonopodis pv. citri in Brazil. Neotropical Enthomology, v.1, p.55-59, 2001.

CIVEROLO, E.L. Citrus bacterial canker disease: The bacterium Xanthomonas campestris pv. citri. In: CITRUS CANKER: AN INTERNATIONAL PERSPECTIVE, Lake Alfred, 1985. Citrus canker: An international perspective. Lake Alfred: Citrus Research and Education Center, University of Florida, 1985. p11-17.

CIVEROLO, E.L. Bacterial canker disease of citrus. Journal of the Rio Grande Valley Horticultural Society, v.37, p.127-146, 1984.

CLAUSEN, C.P. Two citrus leafminers of the far east. Technical Bulletin of the U.S. Departament of Agriculture, v.252, 1931.13p.

COOK, A.A. Association of citrus canker pustules with leaf miner tunnels in North Yemen. Plant Disease, v.72, p.546, 1988.

CROSSE, J.E.; GORDIAN, R.N.; SHAFFER, W.H. Leaf damage as a predisposring factor in the infection of apple shoots by Erwinia amylovora. Phytopathology, v.62, p.176-182, 1972.

CUBERO, J.; GRAHAM, J.H. Genetic relationship among worldwide strains of Xanthomonas causing canker in citrus species and design of new primers for their identification by PCR. Applied and Environmental Microbiology, v.68, p.12571264, 2002.

DA SILVA, A.C.R.; FERRO, J.A.; REINACH, F.C. et al. Comparison of the genomes of two Xanthomonas pathogens with differing host specifities. Nature, v.417, p.459-463, 2002. 
DAFT, G.C.; LEBEN, C. Bacterial blight of soybeans: Epidemiology of blight outbreaks. Phytopathology, v.62, p.57-62, 1972.

DANÓS, E.; BERGER, R.D.; STALL, R.E. Temporal and spatial spread of citrus canker within groves. Phytopathology, v.74, p.904-908, 1984.

DRAPER, N.R.; SMITH, H. Applied Regression Analysis. 3. ed. New York: John Wiley, 1998.

EGEL, D.S.; GRAHAM, J.H.; STALL, R.E. Genomic relatedness of Xanthomonas campestris strains causing diseases of citrus. Applied and Environmental Microbiology, v.57, p.2724-2730, 1991.

GABRIEL, D.W.; HUNTER, J.E.; KINGSLEY, M.T.; MILLER, J.W.; LAZO, G.R. Clonal population structure of Xanthomonas campestris and genetic diversity among citrus canker strains. Molecular Plant-Microbe Interactions, v.1, p.59-65, 1988.

GAGNEVIN, L.; LEACH, J.E.; PRUVOST, O. Genomic variability of the Xanthomonas pathovar mangiferaeindicae, agent of mango bacterial black spot. Applied and Environmental Microbiology, v.63, p.246-253, 1997.

GALAS, D.J.; CHANDLER, M. Bacterial insertion elements. In: BERG, D.E.; HOWE, M.M. (Ed). Mobile DNA. American Society for Microbiology, Washington, D.C.: 1989, p.109-162.

GARIJO, C.; GARCIA, E.J. Phyllocnistis citrella (Stainton, 1856) (Insecta: Lepidoptera: Gracillariidae: Phyllocnistinae) en los cultivos de cítricos de Andalucía (Sur España): Biología, ecología y control de la praga. Boletin de Sanidad Vegetal Plagas, v.20, p.815-816, 1994. 
GASCUEL, O. Concerning the NJ algorithm and its unweighted version UNJ. In: MIRKIN, B.; MCMORRIS, F.R.; ROBERTS, F.; RZHETSKY, A. (Ed.). Mathematical hierarchies and biology. Providence, RI: American Mathematical Society. v.37, p. 149-171, 1997.

GEORGE, M.L.C.; BUSTAMAM, M.; CRUZ, W.T.; LEACH, J.E.; NELSON, R.J. Movement of Xanthomonas oryzae pv. oryzae in southeaste Asia detected using PCR-based DNA fingerprinting. Phytopathology, v.87, p.302-309, 1997.

GILLINGS, M.R.; FAHY, P.C.; BROADBENT, P. BARNES, D. Rapid identification of a second outbrak of asiatic citrus canker in the Northern Territory using the polymease chain reaction and genomic fingerprint. Australasian Plant Pathology, v.24, p.104-111, 1995.

GIMENES-FERNANDES, N.; BARBOSA, J.C.; AYRES, A.J.; MASSARI, C.A. Plantas doentes não detectadas nas inspeções dificultam a erradicação do cancro cítrico. Summa Phytopathologica, v.26, p.320-325, 2000.

GOTO, M. Fundamentals of bacterial plant pathology. San Diego: Academic Press, 1990. 342p.

GOTTWALD, T.R. Spatio-temporal analysis and isopath dynamics of citrus scab in nursery plots. Phytopathology, v.85, p.1082-1092, 1995.

GOTTWALD, T.R.; ALVARES, A.M.; HARTUNG, A.M.; BENEDICT, A.A. Diversity of Xanthomonas campestris pv. citrumelo strains associated with epidemics of citrus bacteial spot in Florida citrus nurseries: correlation of detached leaf, monoclonal antibody, and restriction fragment lenght polymorphism assays. Phytopathology, v.81, p.749-753, 1991. 
GOTTWALD, T.R.; GRAHAM, J.H. Spatial pattern analysis of epidemics of citrus bacterial spot in Florida citrus nurseries. Phytopathology, v.80, p.181-190, 1990.

GOTTWALD, T.R.; GRAHAM, J.H. A device for precise and nondisruptive stomatal inoculation of leaf tissue with bacterial pathogens. Phytopathology, v.82, p.930935, 1992.

GOTTWALD, T.R.; MCGUIRE, R.G.; GARRAN, S. Asiatic citrus canker: spatial and temporal spread in simulated new planting situations in Argentina. Phytopathology, v.78, p.739-745, 1988.

GOTTWALD, T.R.; TIMMER, L.W.; MCGUIRE, R.G. Analysis of disease progress of citrus canker in nurseries in Argentina. Phytopathology, v.79, p.1276-1283, 1989.

GOTTWALD, T.R.; GRAHAM, J.H.; EGEL, D.S. Analysis of foci of asiatic citrus canker in a Florida citrus orchard. Plant Disease, v.76, p.389-396, 1992a.

GOTTWALD, T.R.; GRAHAM, J.H.; RILEY, T.D. The influence of spray adjuvants on exacerbation of citrus bacterial spot. Plant Disease, v.81, p.1305-1310, 1997a.

GOTTWALD, T.R.; GRAHAM, J.H.; SCHUBERT, T.S. An epidemiological analysis of the spread of citrus canker in urban Miami, Florida, and sunergistic interaction with Asian citrus leafminer. Fruits, v.52, p.383-390, $1997 \mathrm{~b}$.

GOTTWALD, T.R.; GRAHAM, J.H.; SCHUBERT, T.S. Citrus canker: the pathogen and its impact. Plant Health Progress. DOI:10.1094/PHP-2002-0812-01-RV. 2002a. http://www.plantmanagementnetwork.org/php.

GOTTWALD, T.R.; REYNOLDS, K.M.; CAMPBELL, C.L.; TIMMER, L.W. Spatial and spatiotemporal autocorrelation analysis of citrus canker epidemics in citrus nurseries and groves in Argentina. Phytopathology, v.82, p.843-851, 1992 b. 
GOTTWALD, T.R.; GRAHAM, J.H.; CIVEROLO, E.L.; BARRET, H.C.; HEARN, C.J. Differential host range reaction of citrus and citrus relatives to citrus canker and citrus bacterial spot determined by leaf mesophyll susceptibility. Plant Disease, v.77, p.1004-1009, 1993.

GOTTWALD, T.R.,; HUGHES, G.; GRAHAM, J.H.; SUN, X.; RILEY, T. The citrus canker epidemic in Florida: The scientific basis of regulatory eradication policy for an invasive species. Phytopathology, v.91, p.30-34. 2001.

GOTTWALD, T.R.; SUN, X.; RILEY, T.; GRAHAM, J. H.; FERRANDINO, F.; TAYLOR, E.L. Geo-referenced spatiotemporal analysis of the urban citrus canker epidemic in Florida. Phytopathology, v.92, p.361-377, 2002 b.

GRAHAM, J. H.; GOTTWALD, T.R.; CUBERO, J.; ACHOR, D.S. Xanthomonas axonopodis pv. citri: factors affecting successful eradication of citrus canker. Molecular Plant Pathology, v.5, p.1-15, 2004.

GRAHAM, J.H.; GOTTWALD, T.R. Research perspectives on eradication of citrus bacterial diseases in Florida. Plant Disease, v.75, p.1193-1200, 1991.

GRAHAM, J.H.; GOTTWALD, T.R.; BROWNING, H.W.; ACHOR, D.S. Citrus leafminer exacerbated the outbreak of Asiatic citrus canker in South Florida. In: INTERNATIONAL CONFERENCE ON Citrus leafminer, Orlando, 1996. Proceedings. Orlando: University of Florida, 1996. p.83.

GRAHAM, J.H.; GOTTWALD, T.R.; CIVEROLO, E.L.; MCGUIRE, R.G. Population dynamics and survival of Xanthomonas campestris in soil in nurseries in Maryland and Argentina. Plant Disease, v.73, p.423-427, 1989.

GRAHAM, J.H.; GOTTWALD, T.R.; FARDELMANN, D. Cultivar-specific interactions for strains of Xanthomonas campestris from Florida that cause citrus canker and citrus bacterial spot. Plant Disease, v.74, p.753-756, 1990. 
GRAHAM, J.H.; GOTTWALD, T.R.; RILEY, T.D.; ACHOR, D. Penetration through leaf stomata and growth of strains of Xanthomonas campestris in citrus cultivars varying in susceptibility to bacterial diseases. Phytopathology, v.82, p.1319-1325, 1992.

GRAHAM, J.H.; GOTTWALD, T.R.; RILEY, T.D.; CUBERO, J.; DROUILLARD, D.L. Survival of Xanthomonas campestris pv. citri (Xcc) on various surfaces and chemical control of asiatic citrus canker (ACC). In: INTERNATIONAL CITRUS CANKER RESEARCH WORKSHOP, Fort Pierce, 2000. http://www.doacs.state.fl.us/canker. Proceedings, Fort Pierce, 2000.

GRAHAM, J.H.; MCGUIRE, R.G.; MILLER, J.W. Survival of Xanthomonas campestris pv. citri in citrus plant debris and soil in Florida and Argentina. Plant Disease, v.71, p.1094-1098, 1987.

HARTUNG, J.S. Plasmid-based hybridisation probes for detection and identification of Xanthomonas campestris pv. citri. Plant Disease, v.76, p.889-893, 1992.

HARTUNG, J.S.; CIVEROLO, E.L. Restriction fragment lenght polymorphism dinthiguish Xanthomonas campestris strains isolated from Florida citrus nurseries from X. c. pv. citri. Phytopathology, v.79, p. 793-799, 1989.

HARTUNG, J.S.; CIVEROLO, E.L. Variation among strains of Xanthomonas campestris causing citrus bacterial spot. Plant Disease, v.75, p.622-626, 1991.

HEPPNER, J.B. Citrus leafminer, Phyllocnistis citrella, in Florida (Lepidoptera: Gracillariidae: Phyllocnistinae). Tropical Lepidoptera, v.4, p.49-64, 1993.

HERMANS, P.W.M.; VAN SOOLINGEN, D.; DALE, J.W. Insertion element IS986 from Mycobacterium tuberculosis: a useful tool for diagnosis and epidemiology of tuberculosis. Journal of Clinical Microbiology, v.28, p.2051-2058, 1990. 
HERMANS, P.W.M.; VAN SOOLINGEN, D.; DALE, J.W.; SCHUITEMA, A.R.J.; MCADAM, R.A.; CATTY, D.; VAN EMBDEN, J.D.A. Insertion element IS986 from Mycobacterium tuberculosis: a useful tool for diagnosisand epidemiology of tuberculosis. Journal Clinical Microbiology, v.28, p.2051-2058, 1991.

JAMES, W.C. Assessment of plant diseases and losses. Annual Review of Phytopathology, v.12, p.27-48, 1974.

KOIZUMI, M. Citrus canker: The world situation. In: Timmer, L.W. (Ed.). Citrus canker: An international perspective. University of Florida/Institute of Food and Agricultural Science, Gainesville; 1985. p. 2-7.

KOIZUMI, M. Factors related to the occurrence of spring canker caused by Xanthomonas citri (Hasse) Dowson. Bulletin of Fruit Tree Research Station. Serie B (Okitsu), v.4, p.115-129, 1977.

KOIZUMI, M.; KIMIJIMA, E.; TSUKAMOTO, T.; TOGAWA, M.; MASUI, S. Dispersal of citrus canker bacteria in droplets and prevention with windbreaks. Proceedings of International Society of Citriculture, v.1, p.340-344, 1996.

KRANZ, J. Measuring plant disease. In: KRANZ, J.; ROTEM, J. (Ed.) Experimental techniques in plant disease epidemiology. Berlin. Springer, 1988. p.35-50.

LARANJEIRA, F.F.; BERGAMIN FILHO, A.; AMORIM, L. Dinâmica e estrutura de focos da clorose variegada dos citros (CVC). Fitopatologia Brasileira, v.23, p.36$41,1998$.

LEACH, J.E.; LEUNG, H.; NELSON, R.J.; MEW, T.W. Population biology of Xanthomonas oryzae pv. oryzae and approaches to its control. Current Opinion in Biotechnology, v.6, p.298-304, 1995. 
LEACH, J.E.; RHOADS, M.L.; VERA CRUZ, C.M.; WHITE, F.F.; MEW, T.W.; LEUNG, H. Assessment of genetic diversity and population structure of Xanthomonas oryzae pv. oryzae with a repetitive DNA element. Applied and Environmental Microbiology, v.58, p.2188-2195, 1992.

LEE, H.A. The increase in resistance to citrus canker with the advance in maturity of citrus trees. Phytopathology, v.11, p.70-73, 1921.

LEITE JÚNIOR, R.P.; MOHAN, S.K. Integrated management of the citrus bacterial canker disease caused by Xanthomonas campestris pv. citri in the State of Paraná, Brazil. Crop Protection, v.9, p.3-7, 1990.

LEITE JÚNIOR, R.P.; EGEL, D.S.; STALL, R.E. Genetic analysis of $h r p$-related DNA sequences of Xanthomonas campestris strains causing diseases of citrus. Applied and Environmental Microbiology, v.60, p.1078-1086, 1994.

LENSKI, R.E. Assessing the genetic structure of microbial populations. Proceedings of National Academy of Science USA, v.90, p.4334-4336, 1993.

MADDEN, L.V.; LOUIE, R.; ABT, J.J.; KNOKE, J.K. Evaluation of tests for randomness of infected plants. Phytopathology, v.72, p.195-198, 1982.

MAGURRAN, A.E. Ecological diversity and its measurement. Princeton University, New Jersey: Press. 1988. 179p.

MINOGUE, K.P. Diffusion and spatial probability models for disease spread. In: JEGER, M.J. (Ed.) Spatial components of plant disease epidemics. New Jersey: Prentice Hall, 1989. p.127-143.

MORVAN, A.S.; AUBERT, S.; GODARD, C.; EL SOLH, N. Contibution of a typing method based on IS256 probing of SmaI-digested cellular DNA to discrimination of European phage type 77 methicillin-resistant Staphylococcus aureus strains. Journal pf Clinical Microbiology, v.35, p.1413-1423, 1997. 
NASCIMENTO, J.F.; RODRIGUES NETO, J.; ALVES, J.M.A.; RÊGO, M.M.; ARAÚJO, A.E.S. Ocorrência de cancro cítrico no estado de Roraima. Summa Phytopathologica, v.29, p.81-82, 2003.

NELSON, R.J.; MARIETTA, R.B.; VERA CRUZ, C.M.; YAP, I.V.; LEACH, J.E.; MEW, T.W.; LEUNG, H. Relationship between phylogeny and pathotype for the bacterial bligth pathogen of rice. Applied and Environmental Microbiology, v.60, p. 3275-3283, 1994.

NELSON, S.C.A simple analysis of disease foci. Phytopathology, v.86, p.332-339, 1996.

NUTTER JÚNIOR, F.W.; WORAWITLIKIT, O. Disease.Pro: A computer program for evaluating and improving a person ability to assess disease proportion. Phytopathology, v.79, p.1135, 1989.

NUTTER JÚNIOR, F.W.; SCHULTZ, P.M. Improving the accuracy and precision of disease assessments: selection of methods and use of computer-aided training programs. Canadian Journal of Plant Pathology, v.17, p.174-184, 1995.

NUTTER JÚNIOR, F.W.; TENG, P.S.; SHOKES, F.M. Disease assessment terms and concepts. Plant Disease, v.75, p.1187-1188, 1991.

OCHIAI, H.; HORINO, O.; MIYAJIMA, K.; KAKU, H. Genetic diversity of Xanthomonas oryzae pv. oryzae strains from Sri Lanka. Phytopathology, v.90, p.415-421, 2000.

ODAERT, M.; BERCHE, P.; SIMONET, M. Molecular typing of Yersinia pseudotuberculosis by using an IS200-like element. Journal of Clinical Micrnhinlngy, v. 34, p.2231-22.35, 1996 
OLSEN, J.E.; SKOV, M.N.; ANGEN, O.; THRELFALL, E.J.; BISGAARD, M. Genomic relationships between selected phage types of Salmonella enterica subsp. enterica serotype typhimurium defined by ribotyping, IS200 typing PFGE. Microbiology, v.143, p.1471-1479, 1997.

OTAL, I.; MARTIN， C.; VINCENT-LEVY-FREBAULT, V.; THIERRY, D.; GICQUEL, B. Restriction fragment length polymorphism using IS6110 as an

- epidemiological marker in tuberculosis. Journal of Clinical Microbiology, v.29, p.1252-1254, 1991.

PALAZZO, D.A.; MALAVOLTA JÚNIOR, V.A.; NOGUEIRA, E.M.C. Influência de alguns fatores climáticos sobre o índice de infecção de cancro círrico, causada por Xanthomonas campestris pv. citri, em laranjeira valência (Citrus sinensis), em Bataguassu, M.S. Fitopatologia Brasileira, v.9, p.283-290, 1984.

PALITTAPONGARNPIM, P.; CHOMYC, S.; FANNING, A.; KUNIMOTO, D. DNA fingerprinting of Mycobacterium tuberculosis isolates by ligation-mediated polymerase chain reaction. Nuclic Acids Research, v.21, p.761-762, 1993.

PELTIER, G.L.; NEAL, D.C. Overwintering of the citrus-canker organism in the bark tissue of hardy citrus hybrids. Journal of Agricultural Research, v.14, p.523-524, 1918.

PESTEL-CARON, M.; ARBEIT, R.D. Characterization of IS 1245 for strain typing of Mycobacterium avium. Journal of Clinical Microbiology., v.36, p.1859-1863, 1998.

PICARDEAU, M.; BULL, T.J.; PRODHOM, G.; POZNIAK, A.L.; SHANSON, D.C.; VINCENT, V. Comparison of a new insertion element, IS1407, with established molecular markers for the characterization of Mycobacterium celatum. International Journal of Systematic Bacteriology, v.47, p.640-644, 1997. 
POHRONEZNY, K.; HEWITT, M.; INFANTE, J.; DATNOFF, L. Wind and windgenerated sand injury as factors in infection of pepper by Xanthomonas campestris pv. vesicatoria. Plant Disease, v.76, p.1036-1039, 1992.

PORTO, O.; DORNELLES, C.M.M.; PORTO, M.D.M. Ocorrência de cancro cítrico no Rio Grande do Sul. In: CONGRESSO BRASILEIRO DE FRUTICULTURA, Recife, 1981. Anais. Recife: Sociedade Brasileira de Fruticultura, 1981. p.13861388.

PRATES, H.S.; NAKANO, O.; GRAVENA, S. "Minadora das folhas dos citros" Phyllocnistis citrella, Stainton, 1856. Campinas: CATI, 1996. 3p. (CATI. Comunicado Técnico, 129).

PRUVOST, O.; HARTUNG, J.S.; CIVEROLO, E.L.; DUBOIS, C.; PERRIER, X. Plasmid DNA fingerprimts distinguish pathotypes of Xanthomonas campestris pv. citri, the causal agent of citrus bacterial canker disease. Phytopathology, v.82, p.485-490, 1992.

PRUVOST, O.; BOHER, B.; BROCHERIEUX, C.; NICOLE, M.; CHIROLEU, F. Survival of Xanthomonas axonopodis pv. citri in leaf lesions under tropical environmental conditions and simulated splash dispersal of inoculum. Phytopathology, v.92, p.336-346, 2002.

RADEMAKER, J.L.W.; HOSTE, B.; LOUWS, F.J.; KERSTERS, K.; SWINGS, J.; VAUTERIN, L.; VAUTERIN, P.; BRUIJN, F.J. Comparison of AFLP and rep-PCR genomic fingerprinting with DNA-DNA homology studies: Xanthomonas as a model system. International Journal of Systematic and Evolutionary Microbiology, v.50, p.665-677, 2000.

RAND, F.V.; PIERCE, W.D. A coordination of our knowledge on insect transmission in plant and animal diseases. Phytopathology, v.10, p.189-231, 1920. 
RASTOGI, N.; ROSS, B.C.; DWYER, B.; GOH, K.S.; CLAVEL-SÉRÈS, S.; JEANTILS, V.; CRUAND, P. Emergence during unsuccessful chemotherapy of multiple drug resistance in a strain of Mycobacterium tuberculosis. European Jornal of Clinical Microbiology and Infectious Disease, v.11, p.901-907, 1992.

RESTREPO, S.; VÉLEZ, C.M.; VERDIER, V. Measuring the genetic diversity of Xanthomonas axonopodis pv. manihotis within different fields in Colombia. Phytopathology, v.90, p.683-690, 2000.

ROSSETTI, V.V. Manual ilustrado de doenças dos citros. Piracicaba. Fealq/Fundecitrus. 2001.

SÃO PAULO. Leis, decretos, etc. Portaria da Coordenadoria de Defesa Agropecuária (CDA) $n^{0} 17$ de 06 de Agosto de 1999. Diário Oficial, 07 de Agosto de 1999. Seção 1, p.14. Dispões sobre a erradicação do cancro cítrico.

SCHNEIDER, S.; ROESSLI, D.; EXCOFFIER, L. Arlequin ver. 2000: a software for population genetics data analysis. Genetics and Biometry Laboratory, University of Geneva, Switzerland: 2000.

SCHOULTIES, C.L.; CIVEROLO, E.L.; MILLER, J.W.; STALL, R.E.; KRASS, C.J.; POE, S.R.; DUCHARME, E.P. Citrus canker in Florida. Plant Disease, v.71, p.388395, 1987.

SCHUBERT, T.S.; MILLER, J.W.; GABRIEL, D.W. Another outbreak of bacterial canker on citrus in Florida. Plant Disease, v.80, p.1208, 1996.

SINHA, M.K., BATRA, R.C.; UPPAL, D.K. Role of citrus leaf-miner (Phyllocnistis citrella Stainton on the prevalence and severity of citrus canker (Xanthomonas citri (Hasse) Dowson). Madras Agricultural Journal, v.59, p.240-245, 1972. 
SMITH, J.M.; HOY, M.A. Rearing methods for Ageniaspis citricola (Hymenoptera: Encyrtidae) and Cirrospilus quadristriatus (Hymenoptera: Eulophidae) realeased in a classical biological control program for citrus leafminer Phyllocnistis citrella (Lepidoptera: Gracillariidae). Florida Entomologist, v.78, p.601-608, 1995.

SOHI, G.S.; SANDHU, M.S. Relationship between Citrus leaf-miner (Phyllocnistis citrella Stainton) injury and Citrus canker [Xanthomonas citri (Hasse) Dowson] incidence on Citrus leaves. Journal of Research Punjab Agricultural University, v.5, p.66-69, 1968.

STALL, R.E.; SEYMOUR, C.P. Canker, a threat to citrus in the gulf-coast states. Plant Disease, v.67, p.581-585, 1983.

STALL, R.E.; CIVEROLO, E.L. Research relating to the recent outbreak of citrus canker in Florida. Annual Review of Phytopathology, v.29, p.339-420, 1991.

STALL，R.E.; MARCOS, G.M.; ECHENIQUE, B.I. Importance of mesophyll in mature-leaf resistance to cancrosis of citrus. Phytopathology, v.72, p.1097-1100, 1982.

STALL, R.E.; MILLER, J.W.; MARCO, G.M.; ECHENIQUE, B.I.C. Population dynamics of Xanthomonas citri causing cancrosis of citrus in Argentina. Proceedings of Florida State Horticultural Society, v.93, p.10-14, 1980.

STANLEY J.; SAUNDERS, N. DNA insertion sequences and the molecular epidemiology of Salmonella and mycobacterium. Journal of Medical Microbiology, v.45, p.236-251, 1996. 
SUN, X.; STALL, R.E.; CUBERO, J.; GOTTWALD, T.R.; GRAHAM, J.H.; DIXON, W.D.; SCHUBERT, T.S.; PEACOCK, M.E.; DICHSTEIN, E.R.; CHALOUX, P.H. Detection of a unique isolate of citrus canker bacterium from Key lime in Wellington and Lake Worth, Florida. In: INTERNATIONAL CITRUS CANKER RESEARCH WORKSHOP, Fort Pierce, 2000. http://www.doacs.state.fl.us/canker. Proceedings, Fort Pierce, 2000.

SUN, X.; STALL, R.E.; JONES, J.B.; CUBERO, J.; GOTTWALD, T.R.; GRAHAM, J.H.; DIXON, W.D.; SCHUBERT, T.S.; CHALOUX, P.H.; STROMBERG, V.K.; LACY, G.H.; SUTTON, B.D. Detection and characterization of a new strain of citrus canker bacteria from key/mexican lime and alemow in South Florida. Plant Disease, v.88, p.1179-1188, 2004.

TENG, P.S. Validation of computer models of plant disease epidemics: a review of philosophy and methodology. Zeitschrift für Pflanzenkrankheiten und Pflanzenschutz, v.88, p.455-459, 1981.

TORMELIN, J.R.; HOWELL, T.A. Distrain: a computer program for training people to estimate disease severity on cereal leaves. Plant Disease, v.72, p.455-459, 1988.

VALE, F.X.R. do; FERNANDES FILHO, E.I.; LIBERATO, J.R.; ZAMBOLIM, L. Quant - A software to quantify plant disease severity. In: INTERNACIONAL WORKSHOP ON PLANT DISEASE EPIDEMIOLOGY, 8, Ouro Preto, 2001. Resumo. Ouro Preto, 2001. p.160.

VAN SOOLINGEN, D.; HERMANS, P.W.M.; HAAS, P.E.W.; SOLL, D.R.; VAN EMBDEN, J.D.A. Occurrence and stability of insertion sequences in Mycobacterium tuberculosis complex strains: evaluation of an insertion sequencedependent DNA polymorphism as a tool in the epidemiology of tuberculosis. Journal of Clinical Microbiology, v.29, p.2578-2586, 1991. 
VENKATESWARLU, C.; RAMAPANDU, S. Relationship between incidence of canker and leafminer in acid lime and sathgudi sweet orange. Indian Phytopathology, v.45, p.227-228, 1992.

VERNIÈRE, C.J.; GOTTWALD, T.R.; PRUVOST, O. Disease development and symptom expression of Xanthomonas axonopodis pv. citri in various citrus plant tissues. Phytopathology, v.93, p.832-843, 2003.

VERNIÈRE, C.J.; PRUVOST, O.; CIVEROLO, E.L.; GAMBIN, O.; JACQUEMOUDCOLLET, J.P.; LUISETTI, J. Evaluation of the Biolog substrate utilization system to identify and assess metabolic variation among strains of Xanthomonas campestris pv. citri. Applied and Environmental Microbiology, v.59, p.243-249, 1993.

VERNIÈRE, C.J; HARTUNG, J.S.; PRUVOST, O.; CIVEROLO, E.L.; ALVAREZ, A.M.; MAESTRI, P.; LUISETTI, J. Characterization of phenotypically distinct strains of Xanthomonas axonopodis pv. citri from Southwest Asia. European Journal of Plant Pathology, v.104, p.477-487, 1998.

VOS, P.; HOGERS, R.; BLEEKER, M.; REIJANS, M.; LEE, T.V.; HORNES, M.; FRIJTERS, A.; POT, J.; PELEMAN, J.; KUIPER, M.; ZABEAU, M. AFLP: a new technique for DNA fingerprinting. Nucleic Acids Research, v.23, p.4407-4414, 1995.

ZADOKS, J.C.; SCHEIN, R.D. Epidemiology and plant disease management. New York, Oxford University Press, 1979. 427p. 